UNIVERSIDADE DE SÃO PAULO

ESCOLA DE ENFERMAGEM

THAÍS ARAÚJO DA SILVA

IDENTIDADE E ESCOLHAS PROFISSIONAIS NA PERSPECTIVA DE GRADUANDOS DE ENFERMAGEM

São Paulo

2015 


\title{
IDENTIDADE E ESCOLHAS PROFISSIONAIS NA PERSPECTIVA DE GRADUANDOS DE ENFERMAGEM
}

\author{
Dissertação apresentada ao Programa de Pós- \\ Graduação em Gerenciamento em \\ Enfermagem (PPGEn), da Escola de \\ Enfermagem da Universidade de São Paulo. \\ Área de concentração: Fundamentos e Práticas \\ do Gerenciamento em Enfermagem e em \\ Saúde \\ Orientador: Prof. Dr. Genival Fernandes de \\ Freitas
}


AUTORIZO A REPRODUÇÃO E DIVULGAÇÃO TOTAL OU PARCIAL DESTE TRABALHO, POR QUALQUER MEIO CONVENCIONAL OU ELETRÔNICO, PARA FINS DE ESTUDO E PESQUISA, DESDE QUE CITADA A FONTE.

Assinatura:

Data:

Catalogação na Publicação (CIP)

Biblioteca "Wanda de Aguiar Horta"

Escola de Enfermagem da Universidade de São Paulo

Silva, Thaís Araújo da

Identidade e escolhas profissionais na perspectiva de graduandos de enfermagem / Thaís Araújo da Silva. São Paulo, 2015.

$171 \mathrm{p}$.

Dissertação (Mestrado) - Escola de Enfermagem da Universidade de São Paulo.

Orientador: Prof. Dr. Genival Fernandes de Freitas

Área de concentração: Fundamentos e Práticas de Gerenciamento em Enfermagem e em Saúde

1. História da enfermagem. 2. Escolha profissional. 3. Enfermagem I. Título. 
Nome: Thaís Araújo da Silva

Título: Identidade e escolhas profissionais na perspectiva de graduandos de enfermagem.

Dissertação apresentada ao Programa de Pós-Graduação em Gerenciamento em Enfermagem da Escola de Enfermagem da Universidade de São Paulo para obtenção do título de Mestre em Ciências

Aprovado em:

\section{Banca Examinadora}

Prof. Dr. Instituição:

Julgamento: Assinatura:

Prof. Dr. Instituição:

Julgamento: Assinatura:

Prof. Dr. Instituição:

Julgamento: Assinatura: 


\section{AGRADECIMENTOS}

Agradeço ao Criador de todo o Universo, que permitiu que meu percurso de vida fosse ao encontro desse momento importante para meu crescimento pessoal, mental e espiritual.

Aos meus pais, principalmente ao meu pai Nelson Gonçalves da Silva, que sempre me motivou e se alegrou com minhas escolhas profissionais, com seus conselhos transcedentais que me fortaleceram e fortalecem.

Agradeço à compreensão dos meus familiares, inclusive do meu marido Andrelino Donizete da Silva, que sempre me apoiou em todos os momentos da minha vida, que sempre me amparou nos momentos difíceis. Incluo aqui, também, minhas cunhadas.

Às minhas irmãs Tatiana Araújo de Albuquerque e Tamara Aráujo da Silva, bem como meu sobrinho Matheus Yuji Araújo Hashimoto, que sempre me incentivaram e compreenderam meus momentos difíceis.

Ao meu Mestre Prof. Dr. Genival Fernandes de Freitas que acreditou em mim e que me fez amadurecer não só profissionalmente, mas como pessoa. Agradeço imensamente pela paciência na orientação e incentivo que tornaram possível a conclusão desta pesquisa.

À Professora Taka Oguisso pelos conselhos e por poder me espelhar em uma pessoa brilhante como ela.

Às Professoras do departamento ENO, em especial à Victória Secaf, Marta Maria Melleiro, Maria de Fátima Prado e Daisy Maria Rizatto Tronchin.

A todos os amigos do grupo de História, Ética e Legislação de Enfermagem, pelo apoio, principalmente à Lily Löw, Bárbara Bonini e Magali Hiromi Takashi.

Agradeço imensamente pelo auxílio em todas as fases dessa minha caminhada a Aline Garcia Rodero Takahira, que foi e é uma pessoa iluminada, sempre pronta 
para ajudar e o esposo dela - Marcos Takahira - por todo o apoio.

Ao incentivo e motivação das minhas amigas Caroline Pereira Guimarães, Daniela Pereira Gallati, Camila Dantas e Dilma Matos Cutias da Silva.

À colaboração e o empenho de Juliana Guisardi Pereira, por me ajudar nas fases precisas desse trabalho.

À equipe de docentes da Faculdade Privada estudada, em especial à Profa Camila Michele Druzian Silveira e ao Coordenador do curso de Enfermagem José Otacílio Matos.

Aos colaboradores da Secretaria de pós-graduação, em especial à Marcia Garcia. A todos os colaboradores da Secretaria do Departamento Eno-EEUSP. 
"A educação é a arma mais poderosa que você pode usar para mudar o mundo"

Nelson Mandela 
Silva TA. Identidade e escolhas profissionais na perspectiva de graduandos de enfermagem [dissertação]. São Paulo: Escola de Enfermagem, Universidade de São Paulo; 2015.

\section{RESUMO}

Introdução: $O$ presente estudo pretendeu valorizar a escuta dos graduandos de enfermagem de uma Instituição de Ensino Superior privada, no Município de São Paulo, a fim de desvelar percepções e significados a respeito do que é ser enfermeiro, bem como as motivações para a escolha profissional, considerando-se as características identitárias tanto individuais como profissionais (valores e crenças) desse coletivo. Objetivos: Mapear e discutir o perfil sócio-demográfico do alunado matriculado no curso de enfermagem da Instituição Superior de Ensino Privado, do Município de São Paulo, local do estudo, referente ao ano de 2014; Conhecer e compreender as percepções e significados atribuídos à identidade do ser enfermeiro a partir das experiências dos estudantes de enfermagem e analisar as motivações e razões apontadas relativas à escolha pelo curso de Enfermagem. Método: Trata-se de um estudo de natureza histórico-social, qualitativa e exploratória, pautado no método da História Oral Temática. Foram entrevistados quinze graduandos de Enfermagem do primeiro e segundo semestres, após convite da pesquisadora e a manifestação livre e espontânea para a participação, por parte dos interessados. Utilizou-se a técnica da entrevista semi-estruturada, guiando-se por questões norteadoras. Foram observadas as recomendações éticas para a realização da investigação científica. Optou-se pela Análise do Discurso de José Luiz Fiorin como base teórica. Resultados e discussão: Foram elaboradas 4 categorias e 19 subcategorias que emergiram dos discursos, a saber: Categoria 1 - Ampliando a compreensão do ser enfermeiro (Identidade para si). Subcategorias: É um profissional importante, que cuida, zela e salva vidas; ser enfermeiro é doação e dedicação; É o profissional que cuida de forma holística; É o profissional que tem grande responsabilidade; É o profissional que tem poder. Categoria 2 - Enfrentando os desafios da escolha profissional (Indícios de uma Identidade para o outro). Subcategorias: Enfermeiro como missionário do cuidado; Empregabilidade; Profissional que trabalha excessivamente; Enfermeira como representante da mulher de vida fácil; Profissional não reconhecido; Profissional mal remunerado. Categoria 3 - Construindo o processo de socialização no contexto da escolha profissional. Subcategorias: Experiência de ter vivenciado uma situação de necessidade de saúde na família; Já ser profissional da área da enfermagem atuante ou não; Ter tido contato com profissionais da enfermagem. Categoria 4 - Projetando o futuro profissional. Subcategorias: Aceitação, respeito, valorização, reconhecimento da profissão do enfermeiro; Compromisso, interação e o cuidado; Estar estável financeiramente; Realização de um sonho no presente momento projetado ao futuro; Trabalhar em uma área específica da enfermagem relacionada às necessidades pessoais vivenciadas no momento presente; Mudança no comportamento. Conclusão: A presente investigação permitiu (re)construir a História a partir das próprias palavras daqueles que a vivenciaram e que participaram de um determinado período, mediante suas referências e, também do seu imaginário, possibilitando a interpretação do momento presente. Assim, na constante luta pelo reconhecimento e construção de uma identidade profissional, o enfermeiro passa continuamente pela busca de uma imagem, que possa corresponder com seus 
anseios e conferir-Ihe direitos, autonomia e respeito.

PALAVRAS-CHAVE: História da Enfermagem. Escolha da profissão. Papel do profissional de enfermagem. Enfermeiro. 
Silva, T. A. Identity and career choices in nursing students perspective [dissertation]. São Paulo: School of Nursing, University of São Paulo; 2015.

\begin{abstract}
Introduction: This study aimed to enhance the listening of nursing students of a private graduation institution in São Paulo, in order to understand perceptions and meanings about what is being a nurse, as well as the motivations for professional choice, considering both the individual and the professional (values and beliefs) identity characteristics of this group. Objectives: Map and discuss the sociodemographic profile of the students enrolled in the nursing program of Higher Private Education Institution, in São Paulo, study site, for the year 2014; Knowing and understanding the perceptions and meanings attributed to the identity of the nurse from the experiences of nursing students and analyzing the identified motivations and reasons related to the choice for the Nursing course. Method: This is a study of socio-historical, qualitative and exploratory nature, based on the method of thematic oral history. Fifteen nursing students from the first and second halves were interviewed, after the researcher inviting them and the free and spontaneous manifestation occuring for participation, from the interested parties. It was used the technique of semi-structured interview, making use of guiding questions. Ethical recommendations for conducting scientific research were observed. We opted for the Discourse Analysis of José Luiz Fiorin as theoretical basis. Results and discussion: We developed four categories and 19 subcategories that emerged from the talks, namely: Category 1 - Extending the understanding of being a nurse (Identity for himself). Subcategories: It is an important professional who takes care, cares and saves lives; being a nurse means donation and dedication; It is the professional who takes care holistically; It is the professional who has great responsibility; It is the professional who has power. Category 2 - Facing the challenges of professional choice (Evidences of Identity for the other). Subcategories: Nurse as a missionary of care; Employability; Professional who works excessively; Nurse to represent the woman of easy virtue; Professional unrecognized; Professional underpaid. Category 3 - Building the socialization process in vocational choice context. Subcategories: Experience of having experienced a situation of health need in the family; Being a professional in nursing active or not; Having had contact with nursing professionals. Category 4 - Designing the professional future. Subcategories: Acceptance, respect, appreciation, recognition of the nursing profession; Commitment, interaction and care; Be financially stable; Realization of a dream at present designed for the future; Working in a specific area of nursing related to personal needs at the present time; Changing in behavior. Conclusion: This research allowed (re)build the history from the own words of those who lived and who participated in a certain period, by their references and also their imagination, enabling the interpretation of the present moment. Thus, in the constant struggle for recognition and construction of a professional identity, nurses continuously search for an image that could match their expectations and give them rights, autonomy and respect.
\end{abstract}

KEYWORDS: History of Nursing. Choice of profession. Role of the nursing professional. Nurse. 


\section{LISTA DE QUADROS}

QUADRO 1 - Requisitos para ingressantes no curso de Enfermagem ...................26

QUADRO 2 - Número de cursos de Enfermagem no Brasil ....................................28

QUADRO 3 - Quadro sinóptico categorial referente à Análise de Identidade,

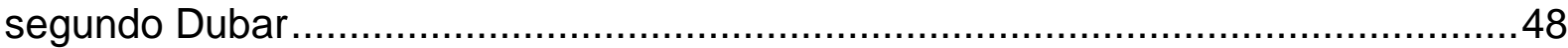

QUADRO 4 - Síntese dos resultados das entrevistas realizadas com os participantes

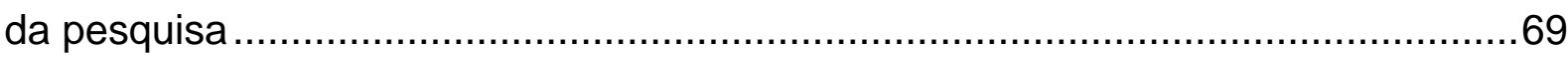




\section{LISTA DE GRÁFICOS}

Gráfico 1 - Caracterização de sexo dos alunos da Faculdade Particular .52 Gráfico 2 - Caracterização da etnia de acordo com os alunos da Faculdade Particular

Gráfico 3 - Caracterização da religião de acordo com os alunos da Faculdade Particular .53

Gráfico 4 - Caracterização da faixa etária dos alunos da Faculdade Particular .......54

Gráfico 5 - Caracterização do estado civil dos alunos da Faculdade Particular .......55 Gráfico 6 - Caracterização da quantidade de pessoas que integram a família dos alunos da Faculdade Particular .55

Gráfico 7 - Caracterização do responsável pela família dos alunos da Faculdade Particular..... .56

Gráfico 8 - Caracterização da renda familiar dos alunos da Faculdade Particular ...56 Gráfico 9 - Caracterização do quantitativo dos alunos que possuem dependente econômico

Gráfico 10 - Caracterização do quantitativo de pessoas que trabalham na família dos alunos.

Gráfico 11 - Perfil do modelo estudantil no Ensino Fundamental de acordo com os alunos da Faculdade Particular .58

Gráfico 12 - Perfil do modelo estudantil no Ensino Médio de acordo com os alunos da Faculdade Particular

Gráfico 13 - Quantidade dos alunos que possuem bolsa estudantil na Faculdade Particular. 60

Gráfico 14 - Tipo de bolsa estudantil que os alunos possuem na Faculdade Particular

Gráfico 15 - Caracterização dos alunos da Faculdade Particular que possuem vínculo empregatício

Gráfico 16 - Caracterização da jornada de trabalho dos alunos da Faculdade Particular......

Gráfico 17 - Caracterização dos alunos da Faculdade Particular que trabalham como auxiliar ou técnico de enfermagem.

Gráfico 18 - Caracterização do tempo em anos dos alunos da Faculdade Particular que trabalham como auxiliar ou técnico de enfermagem 
Gráfico 19 - Caracterização dos alunos que trabalham em outras áreas. .63

Gráfico 20 - Caracterização da escolha profissional pela enfermagem de acordo com os alunos da Faculdade Particular

Gráfico 21 - Caracterização da nacionalidade de acordo com os alunos da Faculdade Particular .65

Gráfico 22 - Caracterização da procedência das regiões do Brasil dos alunos da Faculdade Particular .65

Gráfico 23 - Caracterização da região de residência, no Estado de São Paulo, dos alunos da Faculdade Particular 66

Gráfico 24 - Caracterização do tempo de deslocamento que os alunos levam da residência até a empresa na qual trabalham. .67 Gráfico 25 - Caracterização do tempo de deslocamento da residência dos alunos até a Faculdade .67

Gráfico 26 - Caracterização de horas que os alunos se dedicam por semana para atividades acadêmicas 68

Gráfico 27 - Caracterização das atividades de lazer de acordo com os alunos da Faculdade Particular .68 


\section{SUMÁRIO}

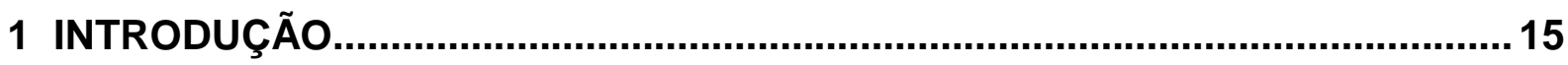

1.1 PENSANDO A TRAJETÓRIA PROFISSONAL E JUSTIFICATIVA DA

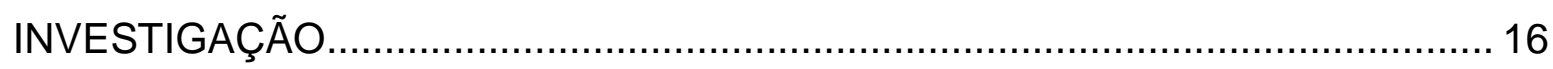

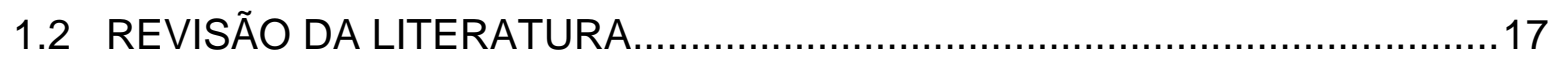

1.3 ENSINO EM ENFERMAGEM NO BRASIL: ALGUNS ELEMENTOS

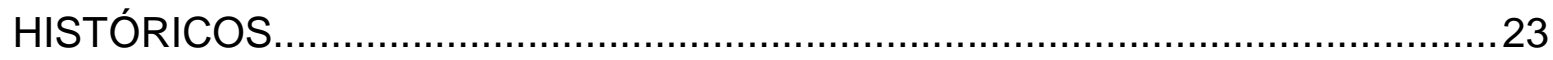

2 OBJETIVOS

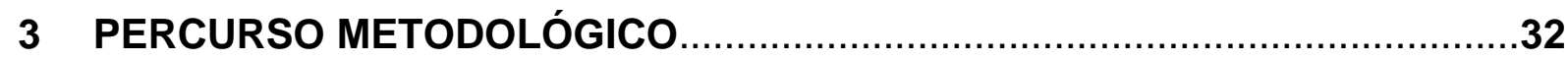

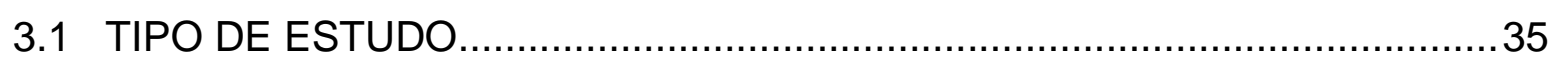

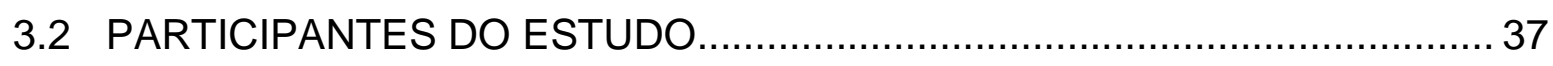

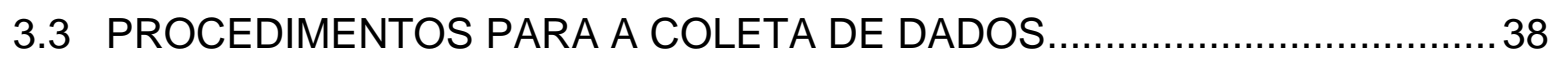

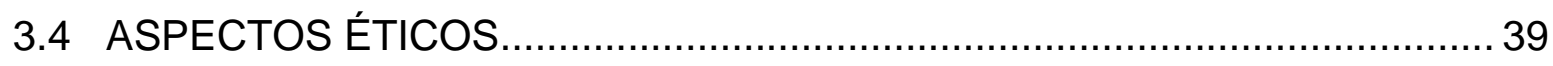

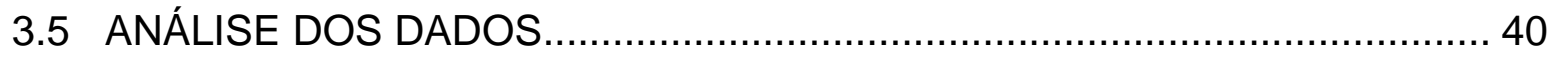

4 REFERENCIAL TEÓRICO

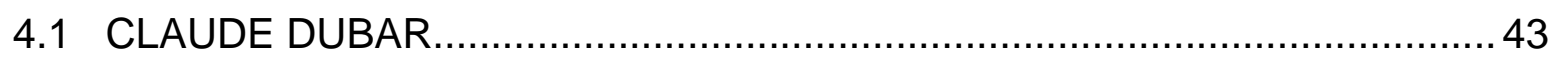

4.2 ELEMENTOS DO CAMPO PROFISSIONAL NA PERSPECTIVA DA

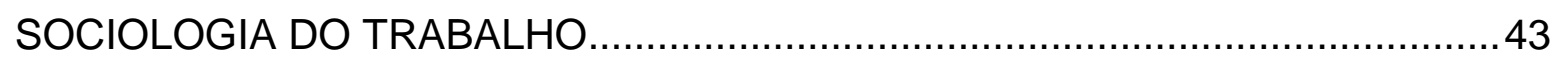

4.3 NUANCES DA(S) IDENTIDADE(S) ...................................................... 45

5 RESULTADOS

5.1 PERFIL DOS GRADUANDOS DA FACULDADE PRIVADA ESTUDADA......51

5.2 SISTEMATIZAÇÃO DOS DADOS ALUSIVOS AOS DISCURSOS DOS

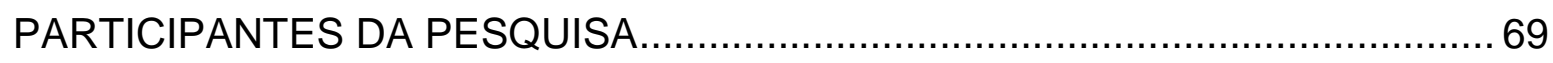

5.2.1 Categorização dos discursos.............................................................

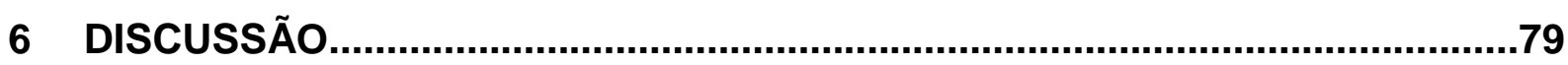

6.1 CONFIGURAÇÕES IDENTITÁRIAS DO ENFERMEIRO ............................ 80 


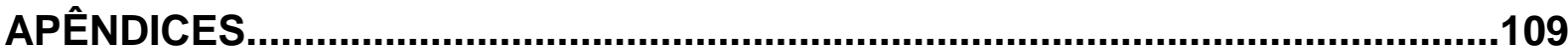

APÊNDICE A - Instrumentos de coleta de dados............................................110

APÊNDICE B - Termo de Consentimento Livre e Esclarecido............................ 112

APÊNDICE C - Entrevistas transcriadas...........................................................115

ANEXO 
1 INTRODUÇÃO 


\section{INTRODUÇÃO}

\subsection{PENSANDO A TRAJETÓRIA PROFISSONAL E JUSTIFICATIVA DA INVESTIGAÇÃO}

A pesquisadora, quando optou seguir sua carreira na Enfermagem, por volta dos seus 20 anos, tinha uma percepção da profissão de Enfermagem totalmente diferenciada da qual tem hoje. Essa mudança adveio da maturidade pessoal e profissional ao longo das experiências e vivências.

Ressalta que sua escolha por essa profissão ocorreu por dois motivos. Primeiramente, ao observar o trabalho e a vida profissional por meio dos amigos e colegas, bem como a estabilidade financeira que essa profissão poderia oferecê-la. O segundo motivo, que à época considerava mais importante e fundamentada no que ela tinha de identidade para si, estava associada à vida espiritual, não de forma religiosa, mas em uma dimensão espiritualista.

Assim, no decorrer de sua formação na Enfermagem, sua atenção se voltou para as questões identitárias do enfermeiro que transcendessem as atribuições e as competências que permeiam essa profissão.

Foi na graduação que compreendeu que o Enfermeiro é um profissional com grandes responsabilidades e valores. Percebeu que suas tarefas estavam relacionadas além do cuidado na assistência, mas envolviam ações gerenciais e empreendedoras. Desse modo, instigava-a a buscar entender e compreender as percepções que os próprios profissionais dessa área tinham para si quanto ao ser enfermeiro.

Após o término da graduação em Enfermagem, atuou por curto tempo na assitência e, em seguida, lecionou em uma Faculdade Privada em São Paulo na Região Central.

Sua trajetória como docente de um curso superior renovou aquela antiga necessidade de aprofundar as questões inerentes à identidade do enfermeiro, pois no percurso dessa atuação, a pesquisadora realizou enquetes questionando aos seus graduandos quanto à escolha pela profissão da Enfermagem e quais motivações os levaram a optarem por essa carreira. Com isso, percebeu a riqueza do campo de investigação histórica, mormente no que tange à escolha pela 
enfermagem, pois havia uma gama variada de explicações sobre a escolha profissional que eles faziam e, mais ainda, uma variedade de interpretações do que é ser enfermeiro e do trabalho desse profissional no contexto social.

Para desvelar as percepções dos graduandos de enfermagem em relação à identidade profissional e à escolha profissional, como um fenômeno a ser investigado, foi desenvolvida a presente pesquisa.

Todavia, para contextualizar a temática proposta, faz-se necessário apreender da literatura aspectos embasados em autores que estudam e investigam esse objeto de estudo.

\subsection{REVISÃO DA LITERATURA}

Para o desenvolvimento desta pesquisa, a pesquisadora levantou trabalhos científicos sobre a temática da escolha e identidade profissional, no período de outubro a novembro de 2014, no portal da Biblioteca Virtual em Saúde (BVS) e na base de dados da Scientific Electronic Library Online (Scielo). No mês de junho de 2015, o levantamento de artigos ocorreu pela base de dados PubMed.

Dos artigos selecionados, 104 foram encontrados na BVS utilizando-se os descritores escolha da profissão, enfermeiro, papel do profissional de enfermagem e a palavra-chave identidade profissional. Foi feito o cruzamento dos descritores escolha da profissão AND enfermeiro, com o filtro regional, em português ou espanhol, com a opção de texto completo, sem delimitação temporal. Com esse tipo de busca, foram encontrados 40 artigos.

Outra seleção realizada, ainda na BVS, foi feita da seguinte maneira: papel do profissional de enfermagem AND identidade profissional, com o filtro regional, em português, com a opção de texto completo, também sem delimitação temporal. Desse modo, foram encontrados 64 artigos.

Do total dessa busca na BVS, foram utilizados cinco artigos, por serem considerados de maior relevância com aproximação à proposta do presente estudo e porque os resumos dos artigos escolhidos aportaram contribuições ao estudo da identidade e da escolha profissional na enfermagem.

$\mathrm{Na}$ base da Scielo, os descritores utilizados foram: escolha da profissão, enfermeiro, identidade própria, e a palavra-chave identidade profissional. Foi feito o 
cruzamento dos descritores escolha da profissão AND enfermeiro, no qual foram encontrados três artigos. Foi inserido isoladamente o descritor identidade própria, sendo localizado um artigo e a palavra-chave identidade profissional, com 40 artigos levantados. Desse total de 44 artigos levantados na Scielo, optou-se pela utilização de dois artigos, pela mesma razão acima apontada, no caso da BVS.

Na base de dados da PubMed foi realizado um levantamento utilizando-se os seguintes descritores: nurses AND social identification. Foram localizados 104 artigos e optou-se pelo uso de dois deles, por atenderem melhor ao interesse do presente trabalho sobre a identidade e as escolhas profissionais. Na PubMed, cruzando-se o descritor nurses e a palavra-chave professional choice, foram levantados dois artigos de interesse para o estudo, possibilitando um alargamento do entendimento da temática sobre a identidade e as escolhas profissionais em enfermagem.

O levantamento feito nas referidas bases resultou em 356 trabalhos, correspondentes ao período entre 1999 a 2012. Destes, foram selecionados 10 trabalhos interessantes à temática estudada, a saber, a Escolha da Profissão e a Identidade Profissional.

Do conjunto dos trabalhos selecionados, merece destaque um estudo realizado por Vieira (1999), cuja análise de dados demonstrou que todos os participantes da pesquisa direcionaram a imagem do enfermeiro no cuidado ao paciente de forma humanitária e evidenciou uma mudança na imagem cultural do enfermeiro, mostrando que as práticas humanitárias devem existir concomitantes ao conhecimento científico para uma boa assistência.

Outro estudo interessante que utilizou o método quanti-qualitativo foi realizado na Universidade Federal de Sergipe com ingressantes e egressos do curso de Enfermagem, no período de 1992 a 2002 e revelou que o motivo principal da escolha pela enfermagem foi que esta facilitou a entrada dos estudantes na Universidade, sendo $42,3 \%$ dos casos. Em se tratando da identificação com a profissão, 46,15\% ocorreu no início das disciplinas profissionalizantes "já que o "ser enfermeiro" começa a se delinear com a disciplina Fundamentos de Enfermagem". Em relação ao futuro da profissão, $80 \%$ das respostas foram positivas ao retratar 0 campo de trabalho e remuneração (Cardoso, Matos, Vieira, 2003, p. 643).

No trabalho de Souza Júnior et al. (2003, p. 453), retrata que a enfermagem foi ampliando espaço aos poucos ao longo do caminho e "hoje no "mundo do 
trabalho" passa-se a exigir do profissional Enfermeiro, determinadas qualidades, essenciais ao contexto sócio-cultural e filosófico de um novo tempo". Esse estudo demonstrou que a escolha da profissão, em primeiro lugar, foi a medicina, porém, quando os candidatos não conseguiram passar no vestibular, eles optaram pela enfermagem. Essa pesquisa ainda ressaltou quanto ao futuro da profissão, na qual evidenciou que a enfermagem vem ganhando maior autonomia e reconhecimento.

Do levantamento feito inicialmente, verificou-se que o processo de (re)construção da identidade do enfermeiro no cotidiano de trabalho foi outro aspecto problematizado em uma pesquisa realizada por Netto e Ramos (2004), em um hospital público, em Cuiabá - Mato Grasso. Nesse caso, os sujeitos do estudo foram enfermeiros, auxiliares de enfermagem, técnicos de enfermagem, médicos, estudantes de medicina e secretárias, no período de setembro a dezembro de 1999.

Os resultados do estudo supracitado apresentaram categorias empíricas que foram importantes para demonstrar o processo de construção da identidade do enfermeiro. A primeira categoria retratou a realidade do trabalho e o processo de construção da identidade do enfermeiro. "Aqui estiveram fortemente presentes os sentidos que o trabalhador enfermeiro atribuiu à realidade cotidiana do seu trabalho". A segunda demonstrou a definição do papel e o processo de construção da identidade do enfermeiro. "Para além de uma identidade corporificada numa tipificação de papel (...), os dados empíricos demonstraram que 'ser enfermeiro' assume significados localmente constituídos no cotidiano do trabalho". A terceira categoria falou sobre o espelho da identidade. "Os dados mostraram que a construção da identidade do enfermeiro se dá na relação do ser consigo e com o outro". E a quarta categoria (manifestações do ser), traz a ideia de que sentimentos e pensamentos pessoais se homogeneízam com o papel das atribuições que a profissão do enfermeiro confere (Netto, Ramos, 2004, p. 53).

Bellagarda et al. (2011, p. 182) comentam sobre a identidade profissional da enfermeira:

A identidade profissional da enfermeira está intimamente ligada ao contexto em que se desenvolve a atividade específica e a quem é desenvolvida, mas também o que resulta dessa atividade, desse trabalho. Assim também a identidade desse profissional se reconfigura a partir da consciência do indivíduo que da profissão usufrui como agente e/ou como requerente de seus benefícios. 
A pesquisa a qual Kemmer e Silva (2007a) realizaram se concentra no âmbito da escolha profissional. Diz que os jovens ao atingirem a idade de escolha de uma profissão, vivenciam um momento crítico. Muitos escolhem uma profissão baseada na representação social da profissão e, também, mediante as suas experiências de vida, tanto no âmbito familiar quanto no coletivo. A pesquisa foi um estudo transversal descritivo e qualitativo, que se pautou na teoria das Representações Sociais. Esse estudo teve a participação de cinco alunos do terceiro ano do ensino médio de uma escola particular na cidade de Londrina (Paraná) e demonstrou a imagem do enfermeiro como um profissional pouco valorizado, sendo um coadjuvante nas tarefas da continuidade no tratamento do paciente no âmbito hospitalar (auxiliar dos médicos), mal remunerado, que trabalha muito e que sofre pelo ato de cuidar. Os participantes desse estudo acreditam que o enfermeiro não necessita de curso superior e que trabalha exclusivamente na área hospitalar. Vale pontuar que há destaque na questão do gênero, onde os alunos apontam a profissão como majoritariamente feminina. Assim, "a motivação da escolha profissional sofre grande influência dos amigos e familiares" (Kemmer, Silva, 2007a, p. 129).

Campos e Oguisso (2008, p. 893) relatam que a identidade de um indivíduo é caracterizada pelas especificações individuais relacionadas ao "nome, filiação, local e data de nascimento, profissão, sexo, e principalmente se pensada através das impressões digitais - marcas que caracterizam a identidade de uma pessoa".

O trabalho de Luchesi et al. (2009) discute a imagem social da Enfermagem. Nesse estudo, foram utilizados dois questionários aplicados aos estudantes de ensino médio. Dentre as profissões (Medicina, Direito, Engenharia, Odontologia, Administração, Psicologia, Fisioterapia, Enfermagem, Computação, Farmácia, Letras, Fonoaudiologia, Serviço Social e Nutrição), a medicina despontou como a mais procurada das profissões dessa área e a enfermagem apareceu em $8^{\circ}$ lugar.

Outro trabalho realizado por Luchesi e Mendes (2010) objetivou construir um questionário multidimensional para avaliar a percepção de alunos do ensino médio sobre a enfermagem e validá-lo em conteúdo, aparência e análise semântica. Desse modo, os resultados mostraram que mundialmente há uma desatualização da imagem da enfermagem e relata que muitos estudos nesse aspecto ainda são descritivos. O estudo possibilitou, ainda, construir "um questionário multidimensional 
para a sondagem da imagem do enfermeiro junto a estudantes de ensino médio" (Luchesi, Mendes, 2010, p.19).

\begin{abstract}
A imagem profissional remete-nos à própria identidade profissional, em sua intrincada rede de significados que se pretendem exclusivos e, portanto, inerentes àquela profissão. A imagem profissional se consubstancia, assim, na própria representação da identidade profissional, que é em si um fenômeno histórico, social e político (Silva, Padilha, Borenstein, 2002, p. 588).
\end{abstract}

O trabalho de Padilha, Nelson e Borenstein (2011) traz importantes reflexões acerca da identidade profissional da enfermagem por meio das biografias e artigos que embasaram a História da Enfermagem. A investigação foi iniciada por textos que abordam o ensino da História da Enfermagem na graduação e na pós-graduação, textos que abordam a "história das mulheres (gênero, biografias) e à prática profissional de enfermagem (currículo, assistência hospitalar e comunitária, organizações de classe, especialidades etc.)" (Padilha, Nelson, Borenstein, 2011, p. 243).

No estudo realizado pelos autores Johnson et al. (2012), expressa-se que o auto-conceito e a identidade profissional do enfermeiro estão incorporados um ao outro, pois o primeiro é atribuído à percepção de quem somos, que inclui autodefinição e auto-consciência. Nessa perspectiva, os autores apontam que a identidade profissional se constrói levando em conta as interações sociais e as relações.

Desse modo, as identidades profissionais se constroem a partir do sentido que os indivíduos dão a elas, pela história de vida de cada um (Lemos et al., 2007).

No Brasil, a identidade profissional do enfermeiro esteve arraigada na simbologia da vocação, como relatam Gastaldo e Meyer (1989). As autoras apontam que a formação do enfermeiro enfatizou a conduta moral, por vezes até em detrimento do conhecimento. Tal assertiva tem sentido no rastro da História da Enfermagem, quando "Florence ao afirmar as bases da profissão confundiu as características da "boa" enfermeira com as da "boa" mulher, reforçando assim, a enfermagem como uma extensão do trabalho doméstico" (Gastaldo, Meyer, 1989, p. 11).

Com base nessa revisão de literatura dos estudos que invocam a temática, a pesquisadora pretendeu, no presente estudo, conhecer e compreender as 
percepções e significados atribuídos pelos graduandos de enfermagem de uma Faculdade Privada a respeito da escolha por essa profissão, considerando suas vivências e expectativas em relação ao futuro, bem como suas experiências formativas na graduação.

O objeto desta investigação, portanto, refere-se à escolha profissional de graduandos em enfermagem, considerando as características identitárias individuais e profissionais (valores e crenças) desse coletivo e o que esses atores sociais trazem consigo a respeito da sua própria escolha profissional e os significados atribuídos ao ser enfermeiro.

A problemática deste trabalho, portanto, diz respeito à identidade profissional e ao processo da escolha profissional. Para tanto, questiona-se:

"Como se dá o processo de escolha pela enfermagem a partir da leitura e das vivências dos estudantes de uma Faculdade Particular? Quais são os fatores que contribuem para a escolha da enfermagem, partindo das percepções e significados que os estudantes atribuem ao ser enfermeiro e à identidade profissional do enfermeiro? "

Luna (2013, pp. 28, 29) afirma que:

\footnotetext{
Um dos recursos úteis no detalhamento do problema de pesquisa é o destrinchar da formulação inicial, buscando destacar as respostas que o pesquisador gosta de obter ou, pelo menos, indicar que aspectos do fenômeno a estudar ele julga necessário cercar. Quanto mais claramente um problema estiver formulado, mais fácil e adequado será o processo de tomada das decisões posteriores.
}

A pesquisa tem por enfoque, então, as questões da escolha e da identidade profissional, a partir da ótica dos graduandos de enfermagem, considerando suas experiências vivenciadas tanto no âmbito acadêmico quanto no ambiente familiar e social.

O fenômeno que se pretende desvelar são as percepções e significados do ser enfermeiro e a escolha profissional por esse grupo social (alunos de um dado curso de enfermagem no Município de São Paulo). Espera-se com isso contribuir para o alargamento da compreensão da enfermagem como profissão a partir dos sujeitos que escolheram essa carreira profissional. 
A presente investigação envolve a identidade e a escolha profissional, especificamente a opção pelo curso de Enfermagem. Por conseguinte, entende-se que seja imprescindível realizar uma breve retrospectiva histórica sobre a formação em enfermagem no Brasil, com o intuito de problematizar a escolha pela carreira da enfermagem, considerando-se, inclusive, a pulverização ou expansão dos cursos superiores no nosso país, especialmente em instituições privadas.

\subsection{ENSINO EM ENFERMAGEM NO BRASIL: ALGUNS ELEMENTOS HISTÓRICOS}

O Decreto no 791, de 27 de Setembro de 1890, criou no Hospício Nacional de Alienados uma Escola Profissional de Enfermeiros e Enfermeiras (Brasil, 1974a). As circunstâncias históricas da sua criação foram bem analisadas por pesquisadores renomados no campo da história da enfermagem, destacando-se Almerinda Moreira, Tiago Braga do Espírito Santo, Fernando Porto e Taka Oguisso, que acenaram para o pioneirismo dessa instituição (EPEE).

Sabe-se que a criação dessa escola seguiu o modelo médico francês, do Dr. Bourneville, o qual tinha escolas de enfermagem na França, no século XIX, como o ensino de enfermagem na Escola Salpêtrière (Moreira, 2003; Moreira, Oguisso, 2005; Moreira, 2007; Oguisso, 2007). Com isso, denota-se o interesse médico em se criar uma instituição para a formação de enfermeiros e enfermeiras para o Hospício Nacional de Alienados, no Rio de Janeiro, capital da República, no final do século XIX, considerando-se a grave crise instaurada naquela instituição nosocomial, entre médicos (psiquiatras) e religiosas Filhas da Caridade de São Vicente de Paulo, resultando na saída dessas últimas do Hospício referido. Com isso, abriu-se a possiblidade de "importação" de um grupo de enfermeiras francesas, formadas em escolas de enfermagem naquele país. Os médicos viam assegurada a assistência aos doentes internados naquele Hospício, e também garantiam a disciplina, a subserviência e a obediência dos trabalhadores da área de enfermagem aos interesses e comandos médicos da época.

Cabe pontuar que a partir de 1921, a referida escola passou a se chamar Escola Profissional de Enfermeiras Alfredo Pinto e, atualmente, é denominada 
Escola de Enfermagem Alfredo Pinto, da Universidade Federal do Rio de Janeiro (Espírito Santo, 2007).

No contexto do final do século XIX, Mott (1999, p. 336) destaca:

... O hospital deixava de ser um lugar sombrio, sem conforto e insalubre, que acolhia num mesmo espaço doentes pobres e mendigos, onde a cura era difícil e rara, e quando ocorria era atribuída à vontade divina. A medicina passava a dominar novas técnicas que ampliavam as possibilidades de cura $[\ldots]$.

No referido contexto, a "primeira escola especialmente criada para a formação de pessoal de enfermagem em São Paulo foi fundada em 1894, no Hospital Samaritano, e aceitava aprendizes apenas do sexo feminino" (Mott, 1999, p. 339).

Vale destacar que a referida Escola de Enfermeiras do Hospital Samaritano de São Paulo foi conduzida por um grupo de enfermeiras britânicas, as quais teriam sido contratadas para organizar o serviço de enfermagem daquela instituição e também a escola de enfermagem (Moreira, 2014). Essa escola seguia o modelo inglês (nightingaleano), ou seja, a diretora da mesma era sempre uma enfermeira. No caso específico do Hospital Samaritano, vale destacar que as aulas eram ministradas em inglês (Medeiros, Tipple, Munari, 1999).

Outra experiência histórica na formação da enfermeira ocorreu com a criação da Escola de enfermeiras da Cruz Vermelha. De acordo com Galleguillos e Oliveira (2001), em 1916 foi criada a Escola Prática de Enfermeiras da Cruz Vermelha Brasileira, que tinha como objetivo preparar as estudantes para atuarem como socorristas voluntárias.

Sobre identidade na formação da enfermeira, Mecone e Freitas (2009, p. 748) destacam:

“[...] a Escola de Enfermagem da Cruz Vermelha Brasileira, instituição formadora da enfermagem de guerra no Brasil, primava por um perfil no qual prevalecia o rigor da disciplina, a pouca idade e resistência física. As imagens da enfermeira de guerra, ao mesmo tempo, evocavam a disciplina militarista peculiar à guerra, e no Brasil aos propósitos de controle social implementado pela política varguista" (grifos nossos).

Outra experiência histórica marcante ocorreu na década de 1920, com o enredo da grave situação que o país passava em relação à saúde pública, por conta da febre amarela, do tifo, da cólera e da tuberculose, o que exigia uma resposta emergente do Estado. Consequentemente, foi criado o Departamento Nacional de Saúde Pública, na referida década. Nesse contexto, o Decreto №15.799, de 10 de 
novembro de 1922, ao aprovar o regulamento do Hospital Geral de Assistência do Departamento Nacional de Saúde Pública, que estabelecia, no seu art. 2a que "anexo ao hospital funcionará a Escola de enfermeiras do Departamento Nacional de Saúde Pública" (Brasil, 1974b).

Em relação à identidade da enfermeira formada naquela Escola do referido Departamento, Barreira (1997, p. 168) destaca a divulgação de um folheto intitulado "A enfermeira moderna: Appello às moças brasileiras", para dizer que essa profissão se configurava como uma atividade eminentemente feminina.

No folheto mencionado dantes, conclamava-se o perfil de devotamento esperado da futura enfermeira:

...agora, porém, deve ser chamada vida de devotamento, porquanto em nenhum outro labor (...) pode a moça encontrar (...) oportunidade de praticar a mais meiga de todas as artes da vida, encontrando ventura e propício ensejo de revelar os próprios dons e que esquecer-se de si mesma (...)" (Brasil, DNSP, 1922, p. 6).

Assim, em 1923, foi fundada a Escola de Enfermeiras, no Departamento, que posteriormente, passou a chamar-se Escola de Enfermeiras D. Ana Néri, cujo modelo de ensino se baseou no modelo anglo americano (Teixeira et al., 2006a).

O Estado passou a ser o principal responsável pela saúde da população, principalmente a partir da década de 1930, evidenciando-se a necessidade de trabalhadores saudáveis devido ao processo de industrialização (Teixeira et al., 2006a).

De acordo com Fernandes (2012), a partir da década de 1940, pela Lei nำ 775 de 06 de agosto de 1949, passou-se a visar o aumento do número das escolas e, com isso, a obrigatoriedade do curso de enfermagem em todo centro universitário. A partir disso, as escolas passaram a não ser mais comparadas com a Escola Anna Nery, e sim, com o Ministério da Educação e Saúde (Fernandes, 2012).

Importante ressaltar a reformulação curricular que ocorreu a partir da Lei $\mathrm{n}^{0}$ 4.024 das Diretrizes e Bases da Educação Nacional (LDB) (Brasil, 1961):

\footnotetext{
A Associação Brasileira de Enfermagem (ABEn) apresentou para o Conselho Nacional de Educação propostas para a criação de um novo currículo que atendesse as propostas da nova legislação. No novo currículo adotado, a ênfase passou a ser dada ao ensino das ciências físicas e biológicas, com enfoque na visão biológica do ser humano dissociado do aspecto social (Becerril, Gómez, 2012, p. 73).
} 
No quadro 1, Monteiro (2009) demonstra a trajetória quanto aos requisitos que as ingressantes de enfermagem deveriam possuir para serem admitidas no curso de enfermagem, no período de 1891 a 1962:

\section{QUADRO 1 - Requisitos para ingressantes no curso de Enfermagem}

\begin{tabular}{|l|l|}
\hline 1891 a 1922 & Saber ler, escrever e contar \\
\hline 1923 a 1949 & $\begin{array}{l}\text { Instrução secundária, sem exigência de certificado de conclusão de } \\
\text { curso secundário }\end{array}$ \\
\hline 1949 a 1961 & $\begin{array}{l}\text { Certificado de curso secundário completo e permissão para } \\
\text { certificado de 1ํo ciclo de curso secundário ou equivalente }\end{array}$ \\
\hline 1962 & Certificado de curso secundário completo \\
\hline
\end{tabular}

Fonte: Monteiro, 2009, p. 75.

Em 1968, ocorreu outra reformulação curricular, através da Lei ํㅡㄴ.540 de 28 de novembro, que teve como meta principal articular o ensino superior com o ensino médio, assim, aumentou a oportunidade de acesso ao ensino superior (Fernandes, 2012).

Com o Parecer no 163 de 28 de janeiro de 1972, Resolução CFE no 4 de 1972, foi definida a carga horária mínima curricular dos cursos de Enfermagem e Obstetrícia e foram incluídas habilitações nas áreas de enfermagem em saúde pública, médico-cirúrgica e obstétrica (Brasil, 1974c).

A partir da década de 1970, houve a necessidade de cada vez mais buscar conhecimento técnico-científico na área da saúde, no Brasil. Com isso, fomentou-se a criação dos primeiros cursos de pós-graduação stricto sensu em Enfermagem, com o primeiro mestrado acadêmico em 1972, na Escola de Enfermagem Anna Nery e em seguida, em 1973, na Escola de Enfermagem da Universidade de São Paulo. $\mathrm{Na}$ década seguinte, a partir de 1980, foi criado o primeiro programa de doutorado em enfermagem, por meio da parceria entre as Escolas de Enfermagem da Universidade de São Paulo e Ribeirão Preto. Assim, muitos enfermeiros puderam iniciar suas atividades como investigadores em nível de pós-graduação stricto sensu, no país, sendo estes primeiros programas de pós-graduação os responsáveis pela recepção de candidatos de dentro e fora do país, em especial aqueles provenientes da América Latina (Guimarães, Miranda, 2002).

Cabe destacar que a fundação da Universidade de São Paulo ocorreu em 25 de janeiro de 1934, pelo Decreto Estadual nº 6.283/34. Em 1942, pelo Decreto-Lei Estadual nำ13.040/42, foi criada a Escola de Enfermagem da Universidade de São 
Paulo (EEUSP), anexa à Faculdade de Medicina. A dirigente dessa Escola, nesse período, foi Edith de Magalhães Fraenkel (Takashi, 2011). O curso de Enfermagem era ministrado em 3 anos. Para o ingresso na graduação em Enfermagem era preciso que a candidata possuísse entre 18 a 35 anos de idade, diploma de Escola Normal ou certificado de conclusão de ginásio. O principal objetivo da formação na EEUSP era preparar enfermeiras para os serviços hospitalares e de saúde pública (Carvalho, 1980).

As atividades acadêmicas na enfermagem revelam os compromissos sociais dessa área com a formação de recursos humanos mais qualificados não só para a pesquisa, mas também para a formação de novos recursos humanos na saúde (Guimarães, Miranda, 2002). De acordo com Collet, Schneider e Corrêa (2000), com um melhor embasamento científico metodológico, a produção de pesquisa aumentou no Brasil a partir da década de 1970 em diversas áreas do conhecimento.

A partir da década de 1980, cabe destacar, que o Brasil passava pelo processo de Redemocratização ${ }^{1}$, com grandes acontecimentos neste período, destacando a Constituição em 1988 e a VIII Conferência Nacional de Saúde. Foi fundamental a participação da Associação Brasileira de Enfermagem (ABEn) na questão de reestruturação do curso de enfermagem, através dos Seminários Nacionais e Regionais realizados sobre o "Perfil e Competência de Enfermeiros", sobre a "Proposta de Currículos Mínimos de Enfermagem" e sobre o "Ensino Superior de Enfermagem", que culminou em um projeto educacional para a enfermagem brasileira, através do Parecer ํㅡ 314/94 e pela Portaria ํo 1721/94, de 15 de dezembro de 1994, do Ministério da Educação. Assim, a ABEn criou os Seminários Nacionais de Diretrizes para a Educação em Enfermagem (SENADEns) (Fernandes, 2012).

Esse Parecer destaca mudanças curriculares, tais como: carga horária mínima: 3500 horas/aula, com duração de no mínimo quatro anos letivos e no máximo seis; o estágio curricular passou a ter duração de 500 horas de duração, sob supervisão docente; e ocorreu um redimensionamento dos conteúdos das ciências humanas e biológicas (Brasil, 1994).

Em 20 de dezembro de 1996, foi sancionada a Lei o 9.394 e ocorreram mudanças na educação nacional com as Diretrizes Curriculares para cada curso de

\footnotetext{
${ }^{1}$ Redemocratização foi um processo que visou a reconstituição da democracia após o decurso da ditadura/autoritarismo (Villaverde, 2009).
} 
graduação (Brasil, 1996). Becerril e Gómez (2012, p. 75) relatam que no capítulo IV,

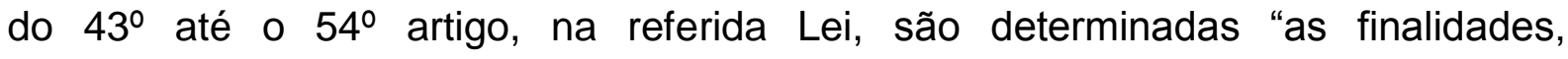
abrangências dos cursos e duração, programas, prerrogativas, funcionamento, caraterísticas, atribuições, competências e determinação do número de dias letivos".

Em 7 de novembro de 2001, foram criadas as Diretrizes Curriculares para o Curso de Graduação em Enfermagem (Resolução CNE/CES, no 3). O artigo 3ำ refere que a formação do enfermeiro pauta-se em um perfil generalista, ético, crítico, reflexivo e humanístico. O artigo 4ํㅜㄹ especifica que o enfermeiro necessita possuir habilidades, como: atenção à saúde, tomada de decisões, comunicação, liderança, administração e gerenciamento, além de educação permanente (Brasil, 2001).

A Resolução n 4, de 6 de abril de 2009, dispõe sobre a carga horária mínima da graduação em enfermagem, sendo 4 mil horas, ou seja, por um período de 5 anos ou 10 semestres letivos (Brasil, 2009).

O Quadro 2 apresenta o número de cursos de enfermagem existentes no período de 1947 a 2004, baseado na obra de Teixeira et al. (2006a):

\section{QUADRO 2 - Número de cursos de Enfermagem no Brasil}

\begin{tabular}{|c|c|}
\hline 1947 & 16 \\
\hline 1964 & 39 \\
\hline 1991 & 106 \\
\hline 2004 & 415 \\
\hline
\end{tabular}

Fonte: Teixeira et al., 2006a.

Fernandes (2012) demostra que no Brasil, no período de 1991 a 2012, a oferta do curso de graduação em Enfermagem cresceu em torno de 800\%. Pode-se observar esse achado na figura abaixo: 
Figura 1 - Oferta de cursos de graduação em Enfermagem por categoria administrativa (1991-2012)

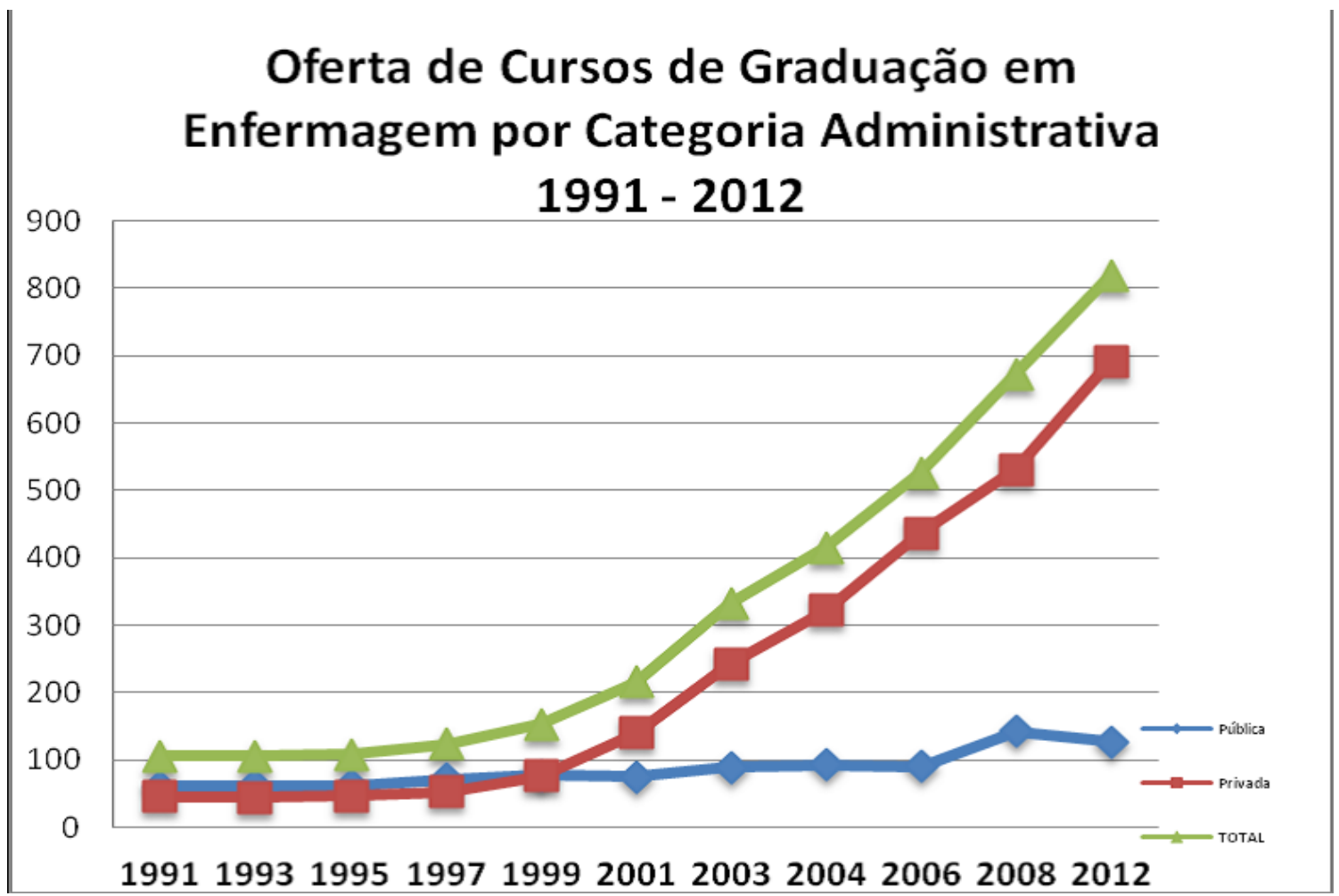

Fonte: Fernandes, 2012.

Outro tópico importante da formação em Enfermagem no país refere-se ao ensino ofertado nessa área por instituições de natureza jurídica privada, tendo em vista que estas cresceram vertiginosamente nas últimas décadas, mormente a partir de 1970. Ademais, o fato do presente estudo ter-se realizado em uma instituição de ensino superior (IES) de natureza privada e também a região de inquérito na qual se voltam as indagações da pesquisadora sobre as percepções do ser enfermeiro e da escolha profissional, na proximidade com graduandos daquela instituição, justifica em boa parte a necessidade de trazer à baila, ao menos parcialmente, o perfil das instituições de ensino privado no país.

Outro aspecto relevante diz respeito ao ensino público e privado na Enfermagem, mormente se for considerada a vertiginosa proliferação de escolas privadas de Enfermagem nas últimas décadas. Nesse sentido, vale a pena pontuar alguns elementos da trajetória histórica das instituições de ensino no Brasil.

Em São Paulo, o ensino superior estava limitado inicialmente à formação em Direito. Consequentemente, com o advento da industrialização, houve a necessidade de que se formassem profissionais técnicos para atender ao 
desenvolvimento econômico. Após a Revolução de 1930, no Brasil, surgiu a primeira regulamentação sobre o ensino superior, com o Estatuto das Universidades Brasileiras (Decreto-Lei no 19.851, de 11 de abril de 1931) (Fávero, 2006).

O período de 1945 a 1968 foi marcado pelo movimento estudantil e de jovens professores que lutavam em oposição às escolas superiores isoladas, pois estes lutavam em defesa do ensino público, principalmente das universidades (Martins, 2002). As principais críticas ao modelo universitário, de acordo com Martins (2002, p.

2) eram:

\begin{abstract}
A instituição da cátedra, a compartimentalização devida ao compromisso com as escolas profissionais da reforma de 1931 (que resistiam à adequação e mantinham a autonomia), e o caráter elitista da universidade. O catedrático vitalício, com poderes de nomeação ou demissão de auxiliares, era tido como empecilho à organização de uma carreira universitária e passou a simbolizar a rigidez e o anacronismo. $\mathrm{O}$ elitismo se refletia no atendimento de parcela mínima da população, sobretudo dos estratos mais privilegiados. O que se pretendia era a extinção da cátedra, com organização departamental dependente de decisões democráticas.
\end{abstract}

Na década de 1970, como relata Sampaio (1999), houve um crescimento acelerado de instituições educacionais privadas. Martins (2002) corrobora essa ideia, dizendo que as instituições educacionais privadas correspondiam 62,3\% das matrículas. É importante salientar que o motivo do crescimento da iniciativa privada ocorreu pelo fato de que as universidades públicas tinham como foco a pesquisa e desse modo elevavam os custos púbicos, assim, abriu-se espaço ao setor privado.

Segundo Sampaio (2011), na década de 1980, desacelerou-se o crescimento das matrículas de nível superior, tanto privadas quanto públicas, porém afetou de forma mais intensa as instituições privadas, devido à diminuição dos egressos do ensino médio. Esse autor ainda relata:

No cenário geral dos anos 1980, conhecida como a década perdida, o País fazia a sua lenta e gradual transição democrática depois de quase 20 anos de regime militar. Com a economia estagnada, só eram crescentes as taxas de desemprego e de inflação e a dupla insatisfação dos setores médios da população brasileira que, também atingidos pelos efeitos da crise econômica, reclamavam seus direitos políticos suspensos durante o regime militar. Na educação, a gravidade do quadro manifestava-se na persistência do alto porcentual de analfabetismo, na restrita cobertura do ensino fundamental, agravada por altas taxas de repetência e de evasão escolar (Sampaio, 2011, p. 30). 
Na década de 1990, as matrículas para o ensino superior no Brasil voltaram a crescer, principalmente em São Paulo e no setor privado (Dourado, 2002).

Com a eleição de Fernando Collor de Mello, no período de 1991 a 1994, foi instituída uma política neoliberal-privatizante, que visava a não participação do Estado na economia, dando liberdade ao comércio e à política de privatização de empresas estatais, para obter crescimento econômico e desenvolvimento social (Almeida, 2010).

Em relação à educação, ainda, Lima (2007, p. 48) destaca que "o modelo neoliberal pode ser visto como uma tentativa de ataque à educação pública, no sentido de que a intervenção do Estado nessa esfera se traduz em perdas para a população". Segundo esse autor, a educação sofreu o impacto daquele projeto neoliberal, com ênfase na privatização, nas leis de mercado, envolvendo os campos do ensino superior e médio.

Observa-se um aumento vertiginoso nas instituições privadas de ensino superior no Brasil. Por exemplo, em 2005, entre 2.165 instituições, apenas 231 instituições eram públicas, ou seja, apenas $10,7 \%$ do total das instituições cadastradas no Cadastro do Instituto Nacional de Estudos e Pesquisas (INEP) (Severino, 2008).

Em 2007, o Plano de Desenvolvimento da Educação (PDE) propunha uma ampliação do acesso ao ensino superior articulado com programas de financiamento para esse nível, destacando-se, no caso do ensino privado, os programas de financiamento do Fundo de Financiamento Estudantil (Fies) e o Programa Universidade para todos (ProUni), com a concessão de bolsas parciais ou integrais para estudantes de baixa renda (Severino, 2008).

Após esse contexto introdutório, a pesquisadora passa a discorrer sobre os objetivos e as questões de método da presente investigação. 
2 OBJETIVOS 


\section{OBJETIVOS}

- Mapear e discutir o perfil sócio-demográfico do alunado matriculado no curso de enfermagem da Instituição Superior de Ensino Privado, do Município de São Paulo, local do estudo, referente ao ano de 2014;

- Conhecer e compreender as percepções e significados atribuídos à identidade do ser enfermeiro a partir das experiências de estudantes de enfermagem de uma instituição de ensino superior privada do Município de São Paulo;

- Analisar as motivações e razões apontadas pelos estudantes de Enfermagem, colaboradores desse estudo, relativas à escolha pelo curso de Enfermagem. 
3 PERCURSO METODOLÓGICO 


\section{PERCURSO METODOLÓGICO}

\subsection{TIPO DE ESTUDO}

Este estudo é de natureza histórico-social, qualitativa, exploratória, pautado no método da História Oral Temática.

O campo dos estudos históricos possibilita o alargamento da compreensão e das realidades sociais, pois, segundo o pensamento do historiador francês Marc Bloch $^{2}$ (2001), a história é compreendida quando o homem é sujeito ativo das ações e fatos vividos. Assim sendo, o ser humano torna-se peça fundamental na construção histórica. Os acontecimentos não devem ser baseados apenas em datas, fatos e relatos, mas sim, atrelados à história individual e coletiva, para se compreender as relações sociais que perpassam as vivências humanas, que se dão em um dado contexto histórico. O objeto principal da História, como ciência, não é o passado em si, mas sim, o homem, lembrando que se deve associar sempre o passado com o presente.

A partir da década de 1920 (mais precisamente em 1929), com o advento da Escola dos Annales ${ }^{3}$, na França, houve um despertar para novas formas de se ver o papel social da História, ampliando o olhar sobre as fontes históricas para além dos documentos ditos oficiais. Passou-se a valorizar também outras formas de manifestação do pensamento humano e das suas práxis social e política. Com isso, os campos de interesse da História foram ampliados, bem como os modos de se escrever a História, envolvendo relações e experiências humanas (Burke, 1989).

Ainda no tocante à construção social da ciência da História, o historiador José d’Assunção Barros (2007), relata que há inúmeros domínios nos campos temáticos da História que podem relacionar-se com o agente que determina a História, como por exemplo, o adolescente, a mulher, o trabalhador, os ambientes urbanos/rurais, a sexualidade, a religião, a arte ou o direito, entre outros. Contudo, há uma grande variedade de escolha quanto aos domínios, pois estes podem se referir ao campo

\footnotetext{
${ }^{2}$ Marc Léopold Benjamim Bloch foi um renomado historiador francês que se destacou por ser um dos fundadores da Escola dos Annales, em 1929 (Bloch, 2001).

${ }^{3}$ Em 1929, por iniciativa de Marc Bloch e Lucien Febvre, surge a Escola dos Analles em torno de uma revista denominada: Anais de história econômica e social (Burke, 1989).
} 
temático, sendo assim, a História da Enfermagem, por exemplo, pode ser considerada sub-especialidade da História Cultural e Social.

Segundo Freitas (2002), a História Oral é uma metodologia importante para poder compreender o cenário contemporâneo, pois reescreve a História, podendo determinar imprescindíveis fatores que denotam a ocorrência de fatos atuais. Esse método utiliza técnicas baseadas em depoimentos de pessoas e escritas, no qual se utiliza a entrevista como instrumento fundamental para a obtenção de dados.

Os depoimentos de pessoas são testemunhas/fontes orais, nos quais são coletados os depoimentos das pessoas entrevistadas. As preocupações desse tipo de abordagem "estarão relacionadas ao tipo de entrevista que será utilizada na coleta de depoimentos, aos cuidados na decodificação e análise destes depoimentos, ao uso ou não de questionários pré-direcionados" (Barros, 2011, p. 133).

A técnica escrita se baseia em registros que foram deixados no passado, "incluindo os objetos da cultura material e as imagens iconográficas, os ambientes urbanos e a própria materialidade de uma cidade" (Barros, 2011, p. 133).

Cassab e Ruscheinsky (2004) mencionam que a aplicação da História Oral torna possível que grupos de indivíduos que não estão inseridos na história oficial, possam introduzir suas percepções em relação à situação apresentada, sob sua própria visão e perspectiva.

Atualmente, a História Oral é focada na relação entrevistador e entrevistado, porém é difícil definir propriamente seu significado na América Latina, a esse respeito, pois há variados estudos que convergem e divergem entre si. Esta dificuldade se relaciona ao fato de "ela não pertencer a um campo estrito do conhecimento, movendo-se em um terreno pluridisciplinar" (Boff, Caregnato, 2008, p. $580)$.

A História Oral se divide em três modalidades (História Oral de vida, História Oral temática e História Oral tradicional). Aqui escolhida a História Oral Temática, pois esta atende melhor aos objetivos da pesquisa proposta, uma vez que o método da História Oral Temática traduz a expressão e opinião do entrevistado sobre um fato ocorrido. No caso, os significados e as percepções que os graduandos de Enfermagem de uma Faculdade Particular têm em relação ao ser enfermeiro e à escolha profissional, por essa área de atuação no campo da saúde. 
É fundamental entender e compreender a História da Enfermagem para que as indagações realizadas sejam respondidas pontuando os motivos para a construção identitária como uma profissão. "A própria história da enfermagem inserida nos cenários sociais ao longo dos tempos, torna-se aberta a aproximações e afastamentos das verdades e seus significados" (Padilha, Borenstein, 2005, p. 576).

\subsection{PARTICIPANTES DO ESTUDO}

Para mapear e discutir o perfil sócio-demográfico do alunado matriculado no curso de Enfermagem da referida instituição, foi aplicado o questionário sócio demográfico que contemplou 300 alunos (Anexo II).

Foram incluídos no estudo aqueles participantes que concordaram em responder ao questionário sobre o perfil sócio-demográfico e participar da realização de uma entrevista.

Foram entrevistados quinze graduandos, sendo oito do primeiro semestre e sete do segundo semestre da graduação em Enfermagem de uma Faculdade Particular situada na região Central de São Paulo. Foram selecionados participantes escolhidos aleatoriamente, de cada um desses semestres, sendo entrevistados homens e mulheres. Esta escolha foi realizada através da busca ativa, diretamente nas salas de aula.

O quantitativo dos participantes elegidos (15 graduandos) para a realização da entrevista foi afixado mediante a satisfação e saturação, que para Marre (1991), o número de entrevistados dependerá se o entrevistador sentir que atingiu os objetivos propostos. Desse modo, quando se começam repetir informações, ou seja, quando as entrevistas posteriores não acrescentam mais nada ao que as outras expressaram, instaura-se o que o autor chama de saturação.

Freitas et al. (2011, p. 372) acrescentam:

O número de sujeitos não é estabelecido previamente, mas sim definido em razão do conteúdo e abrangência dos dados que vão sendo obtidos. As entrevistas são excluídas quando há repetitividade nos depoimentos; quando 0 sujeito não se atem à questão norteadora ou quando 0 pesquisador percebe indução nas respostas. O encerramento da inclusão de novos sujeitos é decidido com base no conjunto dos dados coletados 
que evidenciará tanto a riqueza quanto a abrangência dos significados contidos nos depoimentos

Como critérios de inclusão, para da entrevista, foram definidos que os participantes residissem no município de São Paulo, ou na região metropolitana, porque em geral são alunos trabalhadores e que, por vezes, alegam "falta de tempo" para estudarem e trabalharem. Optou-se por ambos os sexos e foram aceitos, também, aqueles participantes que atuavam em diferentes profissões/funções, inclusive aqueles que já atuavam na área da Enfermagem, como técnicos ou auxiliares.

A escolha desses semestres justifica-se pelo objetivo da pesquisa de apreender e compreender a percepção desses estudantes quanto à identidade profissional do enfermeiro e à escolha profissional, considerando suas vivências e experiências e o que eles trazem da sociedade a respeito da profissão de enfermagem.

\subsection{PROCEDIMENTOS PARA A COLETA DE DADOS}

Após a busca ativa por colaboradores em suas respectivas salas de aula e após a confirmação do interesse de participarem da pesquisa, a pesquisadora apresentou o Termo de Consentimento Livre e Esclarecido (TCLE) e elucidou quaisquer dúvidas.

A escolha pela entrevista como parte dos procedimentos para a coleta de dados se justifica pelo fato de poder observar a comunicação não verbal dos entrevistados, permitindo compreender e assimilar a linguagem corporal (Silva et al., 2004).

As entrevistas foram agendadas de acordo com a disponibilidade do participante. Foram gravadas com o apoio de um suporte digital e em seguida transcritas e transcriadas.

Segundo Luchesi e Lopes (2011, p. 432):

De posse do material gravado, inicia-se a transcrição das entrevistas, o que se constitui na formulação do documento oral para a escrita, que se figura como a primeira etapa da versão escrita da entrevista. Então, esse material bruto se constitui no corpus de análise da história oral. 
Meihi (1991) relata que a transcrição e transcriação são fases fundamentais para transformar o relato oral em texto escrito. A primeira ocorre com a passagem do relato oral para o papel, ou seja, deve-se inserir tudo o que foi relatado, até mesmo as questões do entrevistador. A segunda busca-se levar ao leitor as sensações do relato oral, apoiando-se em instrumentos como a pontuação (exclamação, reticências e interjeição). Desse modo, ocorre uma tentativa de traduzir o que outra pessoa narrou.

Para a aplicação da técnica da História Oral Temática, além do gravador, optou-se pelo uso de um caderno de campo a fim de registrar as impressões da pesquisadora, as quais foram incorporadas no momento de se transcrever os conteúdos de cada entrevista.

As entrevistas foram pautadas em questões norteadoras (APÊNDICE A parte 2), a fim de permitirem aos participantes discorrerem sobre o assunto de forma livre e espontânea.

Para garantir o anonimato, os entrevistados foram identificados por meio de uma sequência numérica arábica (por exemplo: P1, P2, P3, etc.).

\subsection{ASPECTOS ÉTICOS}

Como se trata de uma pesquisa com seres humanos, esse estudo atendeu à Resolução 466/12 do Conselho Nacional de Saúde (CNS, 2012). Sendo assim, fazse necessário seguir as diretrizes atribuídas ao exame dos aspectos éticos das pesquisas que envolvem seres humanos, visando assegurar a dignidade e a proteção dos entrevistados da pesquisa (Brasil, 2013).

Após a aprovação do estudo pelo Comitê de Ética em Pesquisa da Escola de Enfermagem da Universidade de São Paulo (CEP/EEUP - Processo número: 772.015/2014), foi aplicado um TCLE e foi iniciada a coleta de dados (APÊNDICE B). 


\subsection{ANÁLISE DOS DADOS}

No contexto do presente estudo, optou-se pela Análise do Discurso, pois esse tipo de análise concentra-se na visão de mundo expressa pelos participantes e permite revelar as causas dessas visões (Fiorin, 2014).

Quando a Análise do Discurso se correlaciona com os objetivos de um estudo, corrobora com o discurso social, e não exclusivamente individual (Fiorin, 2007).

Fiorin (2005) define Análise do Discurso como sendo uma prática da linguística para compreensão do texto ou de um enunciado, porém essa ação ultrapassa a análise textual ou de uma narração, pois existe uma ideologia empregada no contexto discursivo e/ou textual.

Segundo Fiorin (2007), ao produzir-se um discurso tem-se como resultado uma enunciação, sendo tratada como uma instância logicamente pressuposta pela presença do enunciado, ou seja, é quando alguém diz algo. Para se constituir o domínio da enunciação, necessitam-se de elementos como a pessoa, o tempo e o espaço, ou seja, o eu, o aqui e o agora.

Dessa forma, analisar um discurso, visa não somente a língua, "mas o que há por meio dela: relações de poder, institucionalização de identidades sociais, processos de inconsciência ideológica, enfim, diversas manifestações humanas" (Melo, 2009, p. 3).

Assim, a Análise do Discurso equivale ao chamado percurso gerativo de sentido, sendo este compreendido como "uma sucessão de patamares, cada um dos quais suscetível de receber uma descrição adequada, que mostra como se produz e se interpreta o sentido" e se divide em três níveis: as estruturas fundamentais (profundas), as estruturas narrativas (superficiais) e as estruturas discursivas (Fiorin, 2002, p. 17).

Segundo Fiorin (2014, p. 21), as estruturas fundamentais "abrigam as categorias semânticas que estão na base da construção de um texto". Desse modo, Barros relata que esta categoria "define-se por seu caráter abstrato e constitui, [...], o ponto inicial da geração do discurso".

As estruturas narrativas do percurso gerativo, como integrante semântico, modificam os estados. A sintaxe das estruturas narrativas agrega os enunciados das relações de junção e de transformação (Fiorin, 2014). 
Já as estruturas discursivas do percurso gerativo de sentido são baseadas na concretização das narrativas, que proporciona variações de conteúdo, podendo ocorrer esta variação devido a semântica própria do nível discursivo, portanto, este nível se classifica como o nível das transformações das ideias. Através das figuras, temas e imagens, a semântica discursiva materializa o estado narrativo, sendo que as imagens enfatizam a interpretação do objeto proposto, portanto os temas são investimentos semânticos. Já as figuras buscam representar o objeto proposto. A sintaxe do discurso analisa e objetiva seus elementos e examina com atenção a relação entre o discursista e o interlocutor (Fiorin, 2014).

Assim, a Análise de Discurso oferece subsídios para que permitem conhecer e compreender as múltiplas manifestações e expressões das histórias individuais e sociais de cada participante concernentes à Identidade do que é ser enfermeiro por parte dos estudantes de Enfermagem, e o quanto dessas expressões ou imagens influenciaram na sua própria escolha profissional. 
4 REFERENCIAL TEÓRICO 


\section{REFERENCIAL TEÓRICO}

\subsection{CLAUDE DUBAR}

Claude Dubar é professor de Sociologia na Universidade de Versailles. Dentre suas obras destacam-se: "Analyser lês entretiens biographiques, Sociologie dês professions; La Crise des identités", as quais têm sido amplamente utilizadas por estudiosos em diversos campos do saber, em especial na área de ciências sociais.

Este autor investiga as Identidades Profissionais e a Sociologia do Trabalho, trazendo à luz as variâncias das formas identitárias profissionais que aportam nas relações de trabalho e nas relações sociais e explana que as identidades profissionais são modificadas ao longo da trajetória de vida (Alves et al., 2007).

Visando desenvolver um projeto de pesquisa sobre questões relativas à identidade profissional e escolha profissional da enfermagem, buscou-se um referencial que sustentasse, teoricamente, e fornecesse subsídios para se compreender e aprofundar as questões da identidade profissional.

Os conceitos de Dubar $(1997,2005,2009,2014)$ permitiram clarificar e amparar a presente pesquisa e possibilitaram o alargamento da análise sobre as dimensões identitárias profissionais do enfermeiro, pois ao apropriar-se das percepções dos graduandos do estudo a respeito do que é ser enfermeiro, bem como as motivações ou razões das escolhas desses colaboradores, percebeu-se a necessidade de se aproximar da conceituação teórica de Dubar, que discute vários elementos da identidade de si e do outro, mas o faz em relação à enfermagem.

Cabe pontuar, que esses elementos identitários, detalhados por Dubar, serão abordados, especificamente, no capítulo 4.3.

\subsection{ELEMENTOS DO CAMPO PROFISSIONAL NA PERSPECTIVA DA SOCIOLOGIA DO TRABALHO}

Paralelemente à questão da Identidade foram desenvolvidos estudos sobre as profissões que passaram a ser objeto de estudo da Sociologia, chamado de Sociologia das Profissões. Isso ocorreu a partir da década de 1930 mediante ao 
cenário da Segunda Guerra Mundial por causa das mudanças na economia, das condições sociais e das políticas, surgindo assim, novos grupos profissionais (Rodrigues, 2002).

Kaufmann (2004) relata que na década de 1960, o tema Identidade começou a ser investigado nas Ciências Sociais, porém, de acordo com Dubar (2009) os estudos centrados nas questões das identidades alavancaram somente a partir do final de década de 1970, mediante ao cenário mundial da crise econômica, assim, a abordagem das Identidades passou-se a ser identificada como Contemporânea.

Concomitantemente, neste mesmo período (1970), houve um desenvolvimento da disciplina da Sociologia das Profissões, ocorrendo uma dicotomia com os ideais do funcionalismo ${ }^{4}$ e do interacionismo simbólico ${ }^{5}$, surgindo assim, novas abordagens de análise relativas à identidade e às profissões que antecederam a essa década (Rodrigues, 2002).

Dubar (2005) explica a diferença entre as abordagens interacionistas (do Interacionismo Simbólico) e funcionalistas (do Funcionalismo) que são duas categorias que tratam das Profissões e suas definições. Assim, o interacionismo simbólico, que foi trazido por Hughes, trata da relação entre o profissional e seu utente, cujo termo profissão se traduz em prestígio. Traz, ainda, a divisão do trabalho visando não haver segregação do conjunto de atividades na qual a profissão se insere.

Dubar (1997) relata que o Funcionalismo retrata que a profissão só pode ser válida a partir da competência técnica, necessitando-se assim, ter um código de ética que regule o exercício da profissão.

Embora exista uma gama de sociólogos que estudam a temática "profissão", há inconclusões e divergências quanto ao conceito do termo, como aponta Lemos (2008).

Foi a partir das décadas de 1980 e 1990 que a Sociologia apontou a questão das identidades e do trabalhador. Nessa perspectiva, Fontella (2002, p.68) aponta que:

\footnotetext{
4 "A principal preocupação desta corrente de pensamento era definir, em concreto, as características que um determinado grupo ocupacional deveria cumprir, obrigatoriamente, de forma a poder considerar-se uma profissão" (Henriques, 2011, p. 46).

5 "É uma teoria em que o significado é o conceito central, onde as ações individuais e coletivas são construídas a partir da interação entre as pessoas, que definindo situações agem no contexto social que pertencem" (Lopes, Jorge, 2005, p. 104).
} 
As mudanças no mundo do trabalho obrigam os sociólogos a repensarem as teorias e métodos para dar conta das alterações profundas na identidade dos atores sociais em diferentes esferas, todas interligadas, como família, comunidade, religião, mercado e trabalho.

Rodrigues (2002) sintetiza a trajetória da Sociologia do Trabalho/Profissões dividindo os períodos em quatro segmentos relevantes:

1. Primeiro período: década de 1930 até 1960 - características funcionalistas e interacionistas;

2. Segundo período: década de 1970 - oposição aos interacionistas, mas principalmente aos funcionalistas;

3. Terceiro período: década de 1980 - novas abordagens com ênfase no poder das profissões;

4. Quarto período: atualizações nas teorias com ênfase na sistematização e comparação das profissões.

É importante salientar que mesmo com todos os estudos relacionados à identidade, há diversas definições que se contrapõem, tornando este campo do saber sem uma conclusão definitiva e sólida (Vieira, 2009).

\subsection{NUANCES DA(S) IDENTIDADE(S)}

Goffman (1985, 1988) e Strauss (1999) relatam que a identidade varia de acordo com a interação e a maneira com que os indivíduos se socializam. Para Goffman (1985, 1988), a interação depende dos sujeitos envolvidos que desempenham papéis na sociedade. A interação sistematiza a reciprocidade entre indivíduos sobre o desempenho e ações uns dos outros.

Para Strauss (1999), a identidade está relacionada com situações, sendo que a experiência vivenciada em determinados papéis cooperará com a construção da identidade. 
Salienta-se que os pensamentos de Goffman e Strauss têm como ponto comum a análise da identidade nas relações cotidianas.

Segundo Dubar (2005, p. 136) Identidade é o "resultado a um só tempo estável e provisório, individual e coletivo, subjetivo e objetivo, que, conjuntamente, constroem os indivíduos e definem as instituições".

A identidade, de acordo com Dubar (2005), é desenvolvida na infância pelo processo de socialização familiar e, posteriormente, na escola. É nessa relação de troca de experiências, vivências e exemplos que a criança vai aprendendo e entendendo a ser humano, relacionando as características humanais ao seu modo de vida.

Dubar (2001) demonstra que o caminho para chegar às formas das identidades, é necessário compreender as representações ativas, ou seja, através dos discursos dos indivíduos sobre suas relações sociais. Essas representações ativas podem ser analisadas através das seguintes dimensões:

$\checkmark$ Da interação do indivíduo com o sistema ao qual ele está inserido;

$\checkmark$ Da relação com o futuro;

$\checkmark$ Do modo como ele descreve e vivencia uma situação;

Dubar (2009, p. 15) explica que a identidade está interligada a dois conjuntos diferentes: o essencialismo e o nominalista (também chamada de existencialista). 0 primeiro refere-se à essência original do indivíduo, que não se pode mudar, as chamadas "realidades em si", caracterizado como mesmide, por partir do princípio de que a identidade permanece intacta ao longo da vida. Esse processo se agrupa na forma Comunitária, cuja crença se supõe na "existência de agrupamentos chamados "comunidades", consideradas como sistemas de lugares e nomes préatribuídos aos indivíduos e que se reproduzem de modo idêntico através das gerações". Aqui cada indivíduo é identificado como ser pertencente ao grupo/comunidade, como por exemplo, as culturas, nações, corporações, etnias, entre outros. Desse modo, a identidade está atrelada ao essencialismo, e a concepção de si e de outrem se ligam à identidade do grupo.

O nominalista defende a ideia de que a identidade é mutável e que depende do contexto no qual o indivíduo está inserido e que pode variar na trajetória histórica. Está inserido na forma denominada Societárias onde esta se atrela na transmutação 
e provisória identificação, baseada na escolha pessoal e não nas designações herdadas. É neste ponto de vista (nominalista) que Dubar se atém ao retratar a identidade.

Nessa dinâmica de interação com diversos meios ou grupos no que rege ao conjunto nominalista, ocorrem os processos biográficos que se traduzem na identidade para si (definição de si). Nessa conjuntura, a identidade para si está apoiada nas identidades herdadas, porém passa a sofrer mutações com a entrada no mercado de trabalho. Esse período é estabelecido na transição da adolescência para a vida adulta e que permitem a desenvoltura dos processos relacionais (identidade para o outro/rotulagem por outrem) (Dubar, 2009).

Nessa perspectiva, os espaços de formação, trabalho e emprego são extensões que fazem parte da trajetória de vida dos indivíduos e que permitem legitimar a identidade social que, consequentemente, desenvolve uma identidade profissional.

Ressalta-se que Goffman (1988) denomina as identidades para si como identidades sociais reais e a identidade para o outro como identidades sociais virtuais.

Para que não ocorra uma discrepância entre as identidades virtuais com as identidades reais, emergem estratégias que possibilitam estreitar essas duas configurações e podem ser adotados dois métodos. Um é denominado como transação externa/objetiva e tem como objetivo ajustar essa diferença entre a identidade para si e a identidade para o outro (indivíduo e o outro); e as transações internas/subjetivas que tem como objetivo manter as identidades herdadas, mas com intuito de construir uma nova identidade no futuro (outro e o indivíduo), que neste ponto, é caracterizada como identidades visadas (Dubar, 2005).

Esta dualidade, onde os papéis vão se definindo, juntamente com a aceitação do papel que deverá ser desempenhado, ocorre de forma não linear, pois é produzido de forma dinâmica, haja vista que esse processo é construído socialmente e há situações em que o indivíduo pode se recusar a aceitar uma identificação por outra pessoa (Dubar, 2005).

O Quadro 3 sintetiza o modelo proposto por Dubar (2005), cujas análises dos processos de identificação confluem na composição identitária: 
QUADRO 3 - Quadro sinóptico categorial referente à Análise de Identidade, segundo Dubar

\begin{tabular}{|c|c|}
\hline PROCESSO RELACIONAL & PROCESSO BIOGRÁFICO \\
\hline Identidade para o outro & Identidade para si \\
\hline $\begin{array}{c}\text { Atos de atribuição } \\
\text { "que tipo de homem (ou de mulher) } \\
\text { você é" }\end{array}$ & $\begin{array}{c}\text { Atos de pertencimento "que tipo de } \\
\text { homem (ou de mulher) você quer ser" }\end{array}$ \\
\hline Identidade social virtual & Identidade social real \\
\hline Transação objetiva & Transação subjetiva \\
\hline $\begin{array}{c}\text { Transação objetiva (Identidades } \\
\text { atribuídas/propostas; Identidades } \\
\text { assumidas/incorporadas }\end{array}$ & $\begin{array}{c}\text { Transação subjetiva (Identidades } \\
\text { herdadas; Identidades visadas) }\end{array}$ \\
\hline \hline \multicolumn{2}{|c|}{ IDENTIDADE SOCIAL MARCADA PELA DUALIDADE } \\
\hline
\end{tabular}

Fonte: Adaptado pela pesquisadora a partir da obra de Dubar (2005, p. 142).

A identidade não se pressupõe, necessariamente, como fruto do mundo social, mas sim, no sentido de que a personalidade individual é formada progressivamente pela cultura a partir do momento em que o indivíduo se sente pertencente àquela sociedade, lembrando que a realidade social é diversificada, portanto, não pode ser vista em uma única dimensão (Dubar, 2005).

O processo identitário do ser enfermeiro é histórico e, portanto, dinâmico. Consequentemente, tal processo não se encontra parado ou isolado. Essa assertiva justifica-se nos discursos escolhidos, pois como será demonstrado revelam a heteroglossia de significados do ser enfermeiro.

A heteroglossia se dá por meio da "multiplicidade de vozes sociais e a extensa variedade de relações e inter-relações" (Thives, 2008, p. 3). Assim, "possibilita perceber o que está na margem, incorporando as formas vivas de linguagem, como processo formativo e flexível" (Thives, 2008, p. 3).

Os indivíduos, principalmente os mais jovens que se encontram em fase de decisão pela carreira que desejam seguir, aspiram a profissionalização, no sentido de que necessitam escolher uma profissão que exista uma graduação para tal formação, aspirando a um verdadeiro ofício reconhecido (Dubar, Tripier, Boussard, 2011).

Ao escolher uma profissão, os indivíduos relacionam seu modo de viver, suas experiências individuais e sociais, bem como sua identidade pessoal quanto à identidade profissional pré-concebida face à sua escolha profissional.

Dubar (2005) revela que a identidade profissional faz parte de um grupo que agrega indivíduos que integram esse meio e que representam o papel do 
profissional de acordo com as características do conjunto historicamente construído. Esse conjunto, por sua vez, envolve múltiplas identidades, ou seja, características do coletivo, da organização, individual e social.

A fim de compreender o perfil dos graduandos dessa pesquisa, realizou-se um mapeamento sobre as características sócio-demográficas dos estudantes da IES privada, local do estudo. Assim, a pesquisadora apresenta, a seguir, parte dos achados sobre o perfil do alunado que frequenta o curso de Enfermagem daquela instituição e, em seguida, são apresentados os resultados qualitativos da pesquisa, de acordo com os objetivos delineados previamente. 
5 RESULTADOS 


\title{
5 RESULTADOS
}

O perfil dos graduandos de enfermagem da IES privada, lócus da realização da presente investigação, foi um dado relevante para o estudo, pois norteou a pesquisa e caracterizou quem eram esses alunos, suas condições de vida, seus costumes e sua origem.

Desse modo, a caracterização do perfil será abordada nas próximas subseções.

\subsection{PERFIL DOS GRADUANDOS DA FACULDADE PRIVADA ESTUDADA}

Para obter o perfil sócio-demográfico dos graduandos de enfermagem da Faculdade Particular investigada nessa pesquisa, foi distribuído um formulário (APÊNDICE A - parte 1) e os alunos, espontaneamente, dispuseram-se a participar do levantamento, após a pesquisadora ter explicado as razões do estudo, seus objetivos e metodologia. Tal formulário foi distribuído nas salas de aula da referida instituição.

A abordagem dos dados empíricos sobre esse levantamento possibilitou complementar o estudo para posterior avaliação e inter-relação com os discursos.

No final, foram obtidos 300 respondentes, que voluntariamente participaram, preenchendo o formulário dos dados sobre o perfil dos estudantes daquela instituição.

Os resultados mostraram predominância do sexo feminino, em 82\% (Gráfico 1). Vale ressaltar que a questão de gênero na Enfermagem é amplamente discutida. Passos (1996, p. 19) retrata bem esse ponto de vista:

\begin{abstract}
A enfermagem é uma atividade que sempre foi vista como afeita ao ser feminino à medida que ela tem sido identificada como um ato de cuidar, que exige de quem a executa características que são vistas como fazendo parte da "natureza" feminina. Por conta disso, acaba sendo difícil definir o seu estatuto, ou seja, se ela é uma ciência, se é uma arte ou uma prática social.
\end{abstract}

Nos dias de hoje homens são vistos trabalhando na área da Enfermagem, até mesmo em setores como a pediatria, neonatologia e obstetrícia, porém, a presença 
deles apresenta um percentual baixo, pois ainda preside o preconceito do homem que atua nessa área. O preconceito pode ser visto pela sociedade e até mesmo dentro da própria equipe de enfermagem e que segundo Oxtoby (2003), os profissionais do sexo feminino demonstram discriminação ao sexo oposto, considerando-o preguiçoso e pouco capacitado para a função. O autor relata, ainda, que existe outro estereótipo que eventualmente é encontrado quando se trata da presença masculina na enfermagem, que o classifica como homossexual.

\section{Gráfico 1 - Caracterização de sexo dos alunos da Faculdade Particular}

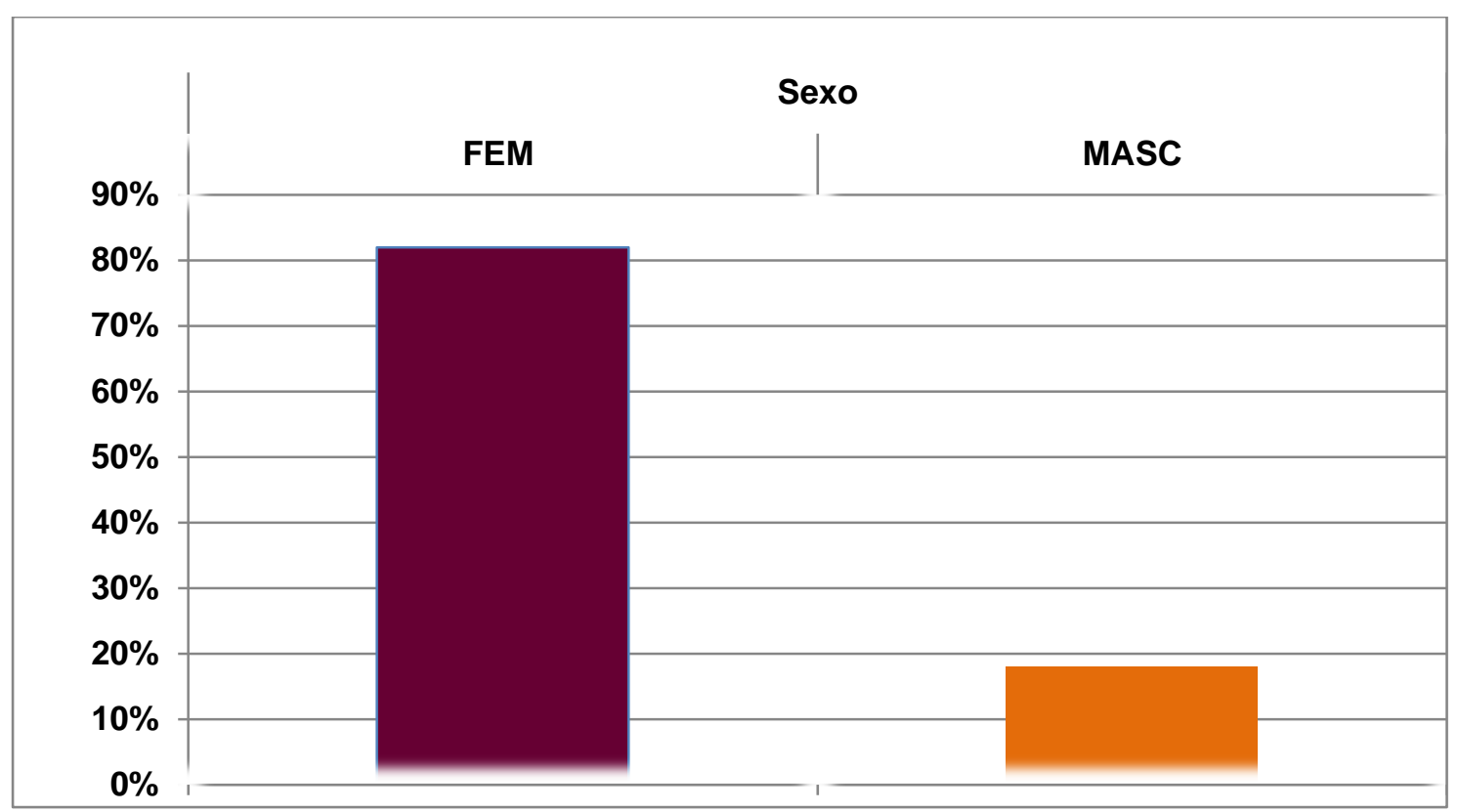

Outro fator que chama atenção está relacionado à etnia. A maioria dos alunos se considera de etnia branca, em um total de 35\%, como demonstrado no Gráfico 2.

Embora a miscigenação ${ }^{6}$ seja uma característica na sociedade brasileira, ainda se discute quanto à classificação da etnia das pessoas serem consideradas negras ou brancas (Sacramento; Nascimento, 2011).

Gonçalves (2012, p. 8) discute a ideia da eugenia ${ }^{7}$ na Enfermagem:

(...). A Enfermagem moderna brasileira nasce elitista e sob a égide da ugenia discriminando classe e principalmente etnia. Sendo os negros e mestiços considerados não dignos e causadores de grandes males foram assim relegados às funções menos valorizadas. $E$ nesse contexto,

\footnotetext{
${ }_{7}^{6}$ Reprodução de indivíduos de diferentes etnias (Dicionário da Língua Portuguesa, 2014).

7 "A palavra 'eugenia', cunhada por Francis Galton em 1883, significa a ciência do melhoramento biológico do tipo humano" (Castañeda, 2003, p. 902).
} 
encontrava-se a mulher negra impedida de ingressar na Escola profissional, pois, estava fora da representação social construída para "boa enfermagem": mulher branca, jovem, saudável, de boa conduta moral.

Gráfico 2 - Caracterização da etnia de acordo com os alunos da Faculdade Particular

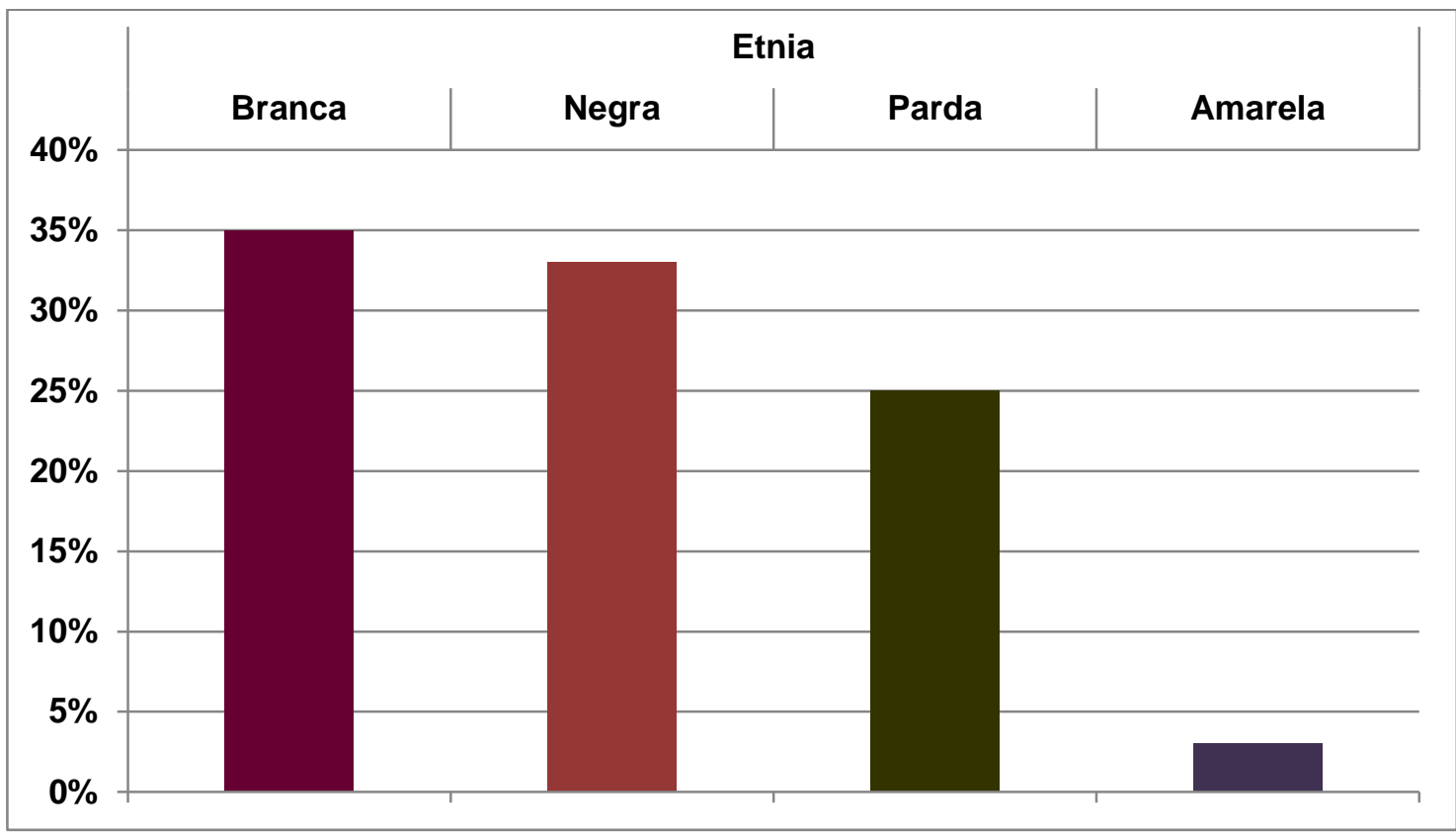

Em se tratando de religião, houve predominância da religião evangélica, em $40 \%$, e $26 \%$ se identificaram como católicos, como demonstra o Gráfico 3.

Gráfico 3 - Caracterização da religião de acordo com os alunos da Faculdade Particular

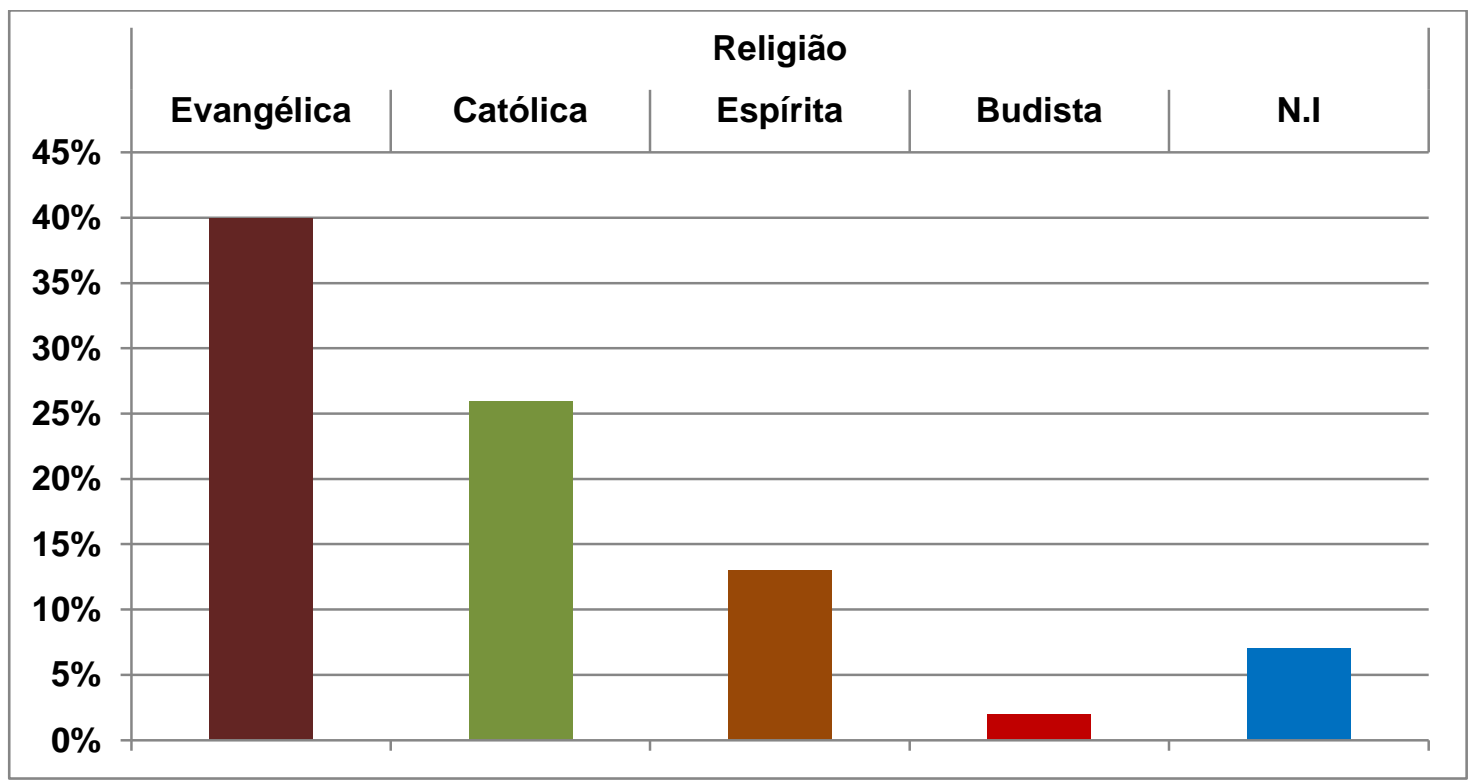


Mesmo que as religiões supracitadas tenham particularidades diferenciadas em suas doutrinas, ambas estão pautadas no Cristianismo.

Vale destacar que a cultura dos cuidados é mais antiga do que se imagina, pois desde os povos mais primitivos, o cuidado tornou-se elemento fundamental para a sobrevivência humana. A história da enfermagem não é diferente, pois com o advento do cristianismo observa-se forte influência e presença religiosa nos cuidados aos doentes, pobres e abandonados, com base nos ensinamentos cristãos do amor e da caridade (Siles Gonzáles et al., 2010; Oguisso, 2007).

Ainda no tocante às características sócio-demográficas dos graduandos da IES, lócus desse trabalho, refere-se à predominância da faixa etária dos estudantes entre 31 e 40, totalizando 38\% (Gráfico 4).

\section{Gráfico 4 - Caracterização da faixa etária dos alunos da Faculdade Particular}

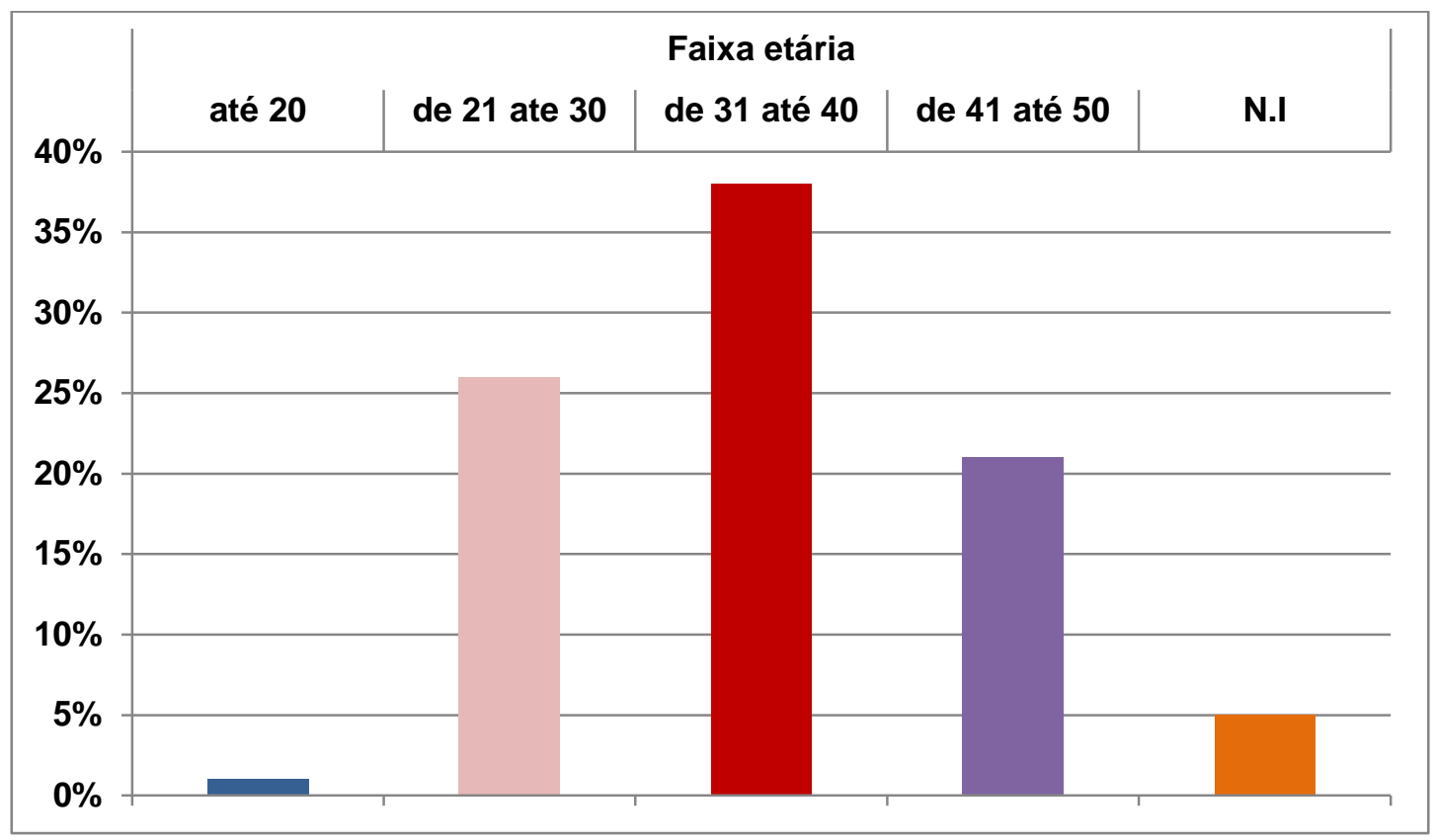

"Dados recentes do Censo da Educação Superior mostram que cerca da metade dos 7 milhões de estudantes têm mais de 20 anos de idade e que, destes, cerca de 600 mil têm mais de 40 anos de idade" (Ristoff, 2014, p. 726).

O perfil sócio-demográfico demonstra, ainda, que a maioria dos estudantes da Faculdade Privada investigada é casada como apresentado no Gráfico 5. 
Gráfico 5 - Caracterização do estado civil dos alunos da Faculdade Particular

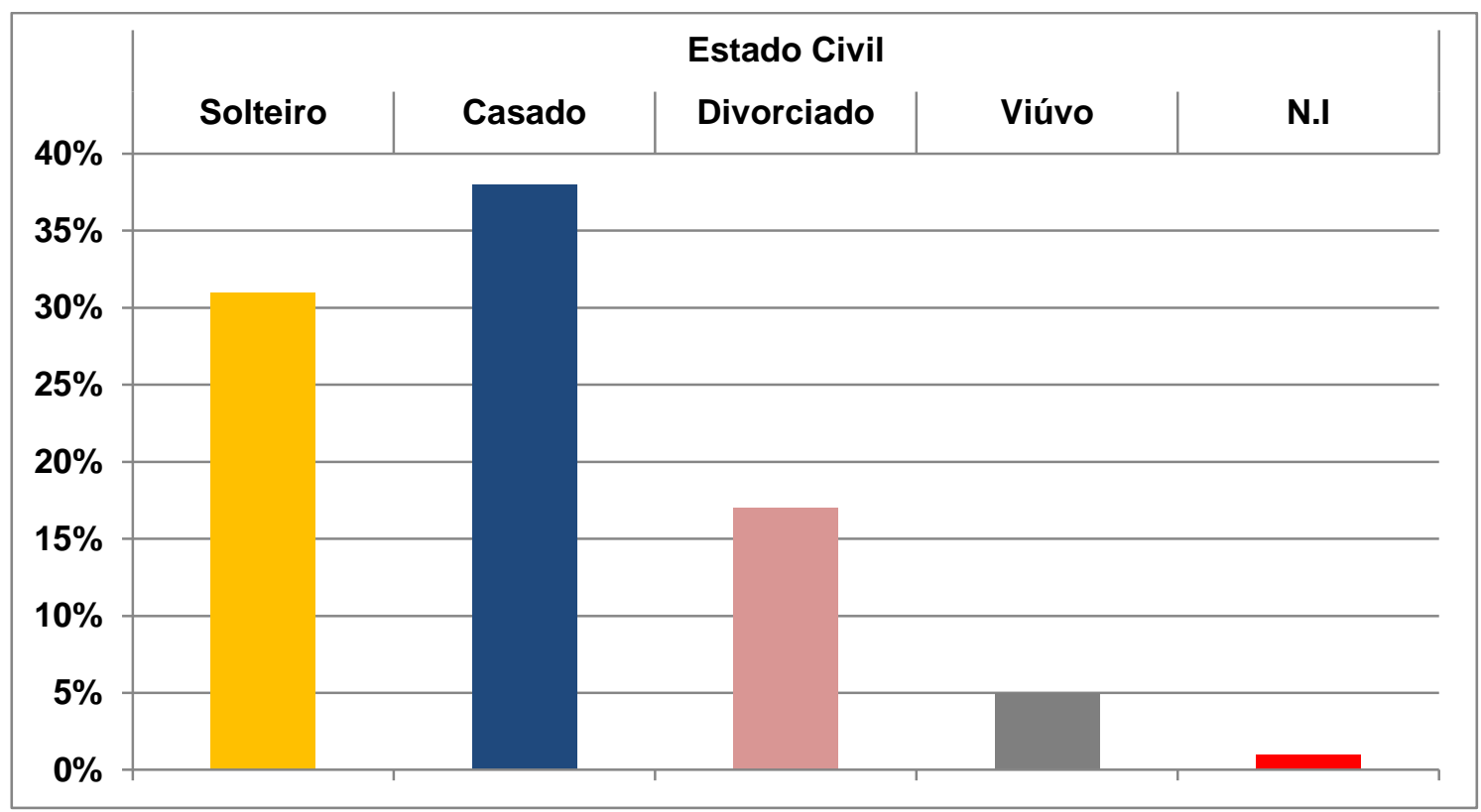

O Gráfico 6 apresenta o quantitativo de integrantes que fazem parte da família dos graduandos, demonstrando que $26 \%$ possuem 4 integrantes na família, sendo que o responsável pela família é o cônjuge, perfazendo um percentual de $31 \%$ e de $30 \%$ a própria pessoa, como demonstrado no Gráfico 7.

Gráfico 6 - Caracterização da quantidade de pessoas que integram a família dos alunos da Faculdade Particular

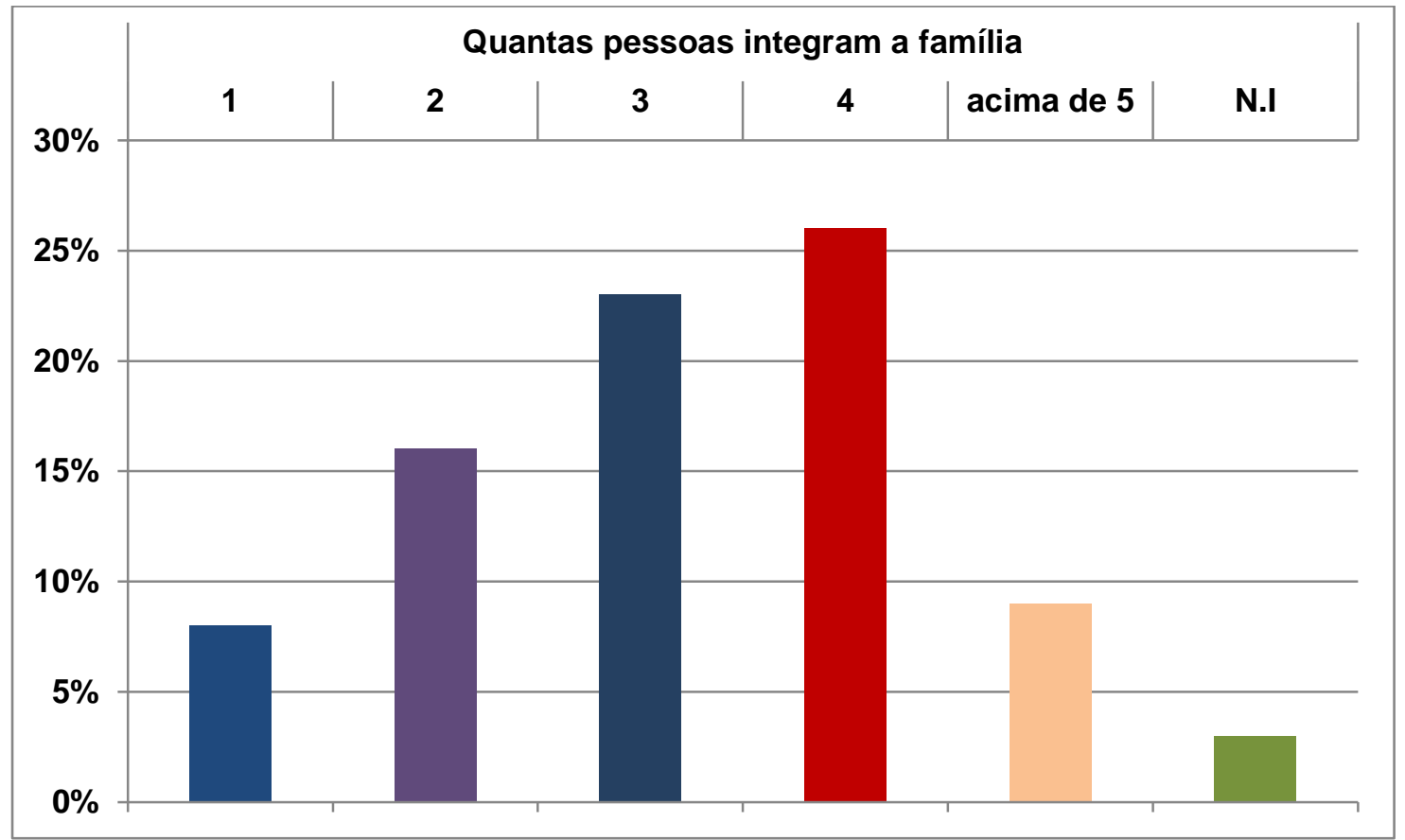


Gráfico 7 - Caracterização do responsável pela família dos alunos da Faculdade Particular

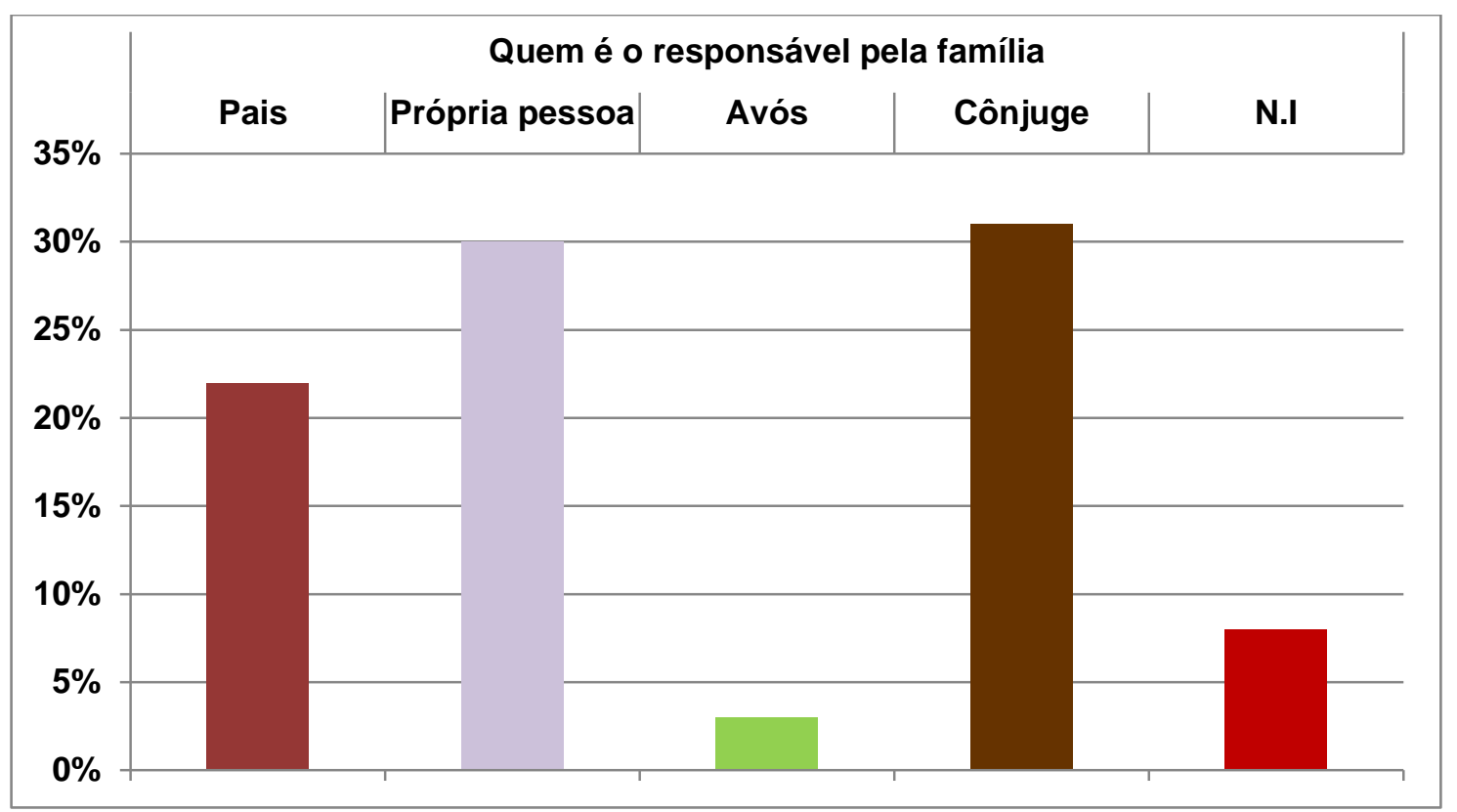

A maior evidência (40\%) da renda familiar está entre mil a três mil reais, como apresentado no Gráfico 8, sendo que $60 \%$ têm pelo menos um dependente econômico (Gráfico 9).

Gráfico 8 - Caracterização da renda familiar dos alunos da Faculdade Particular

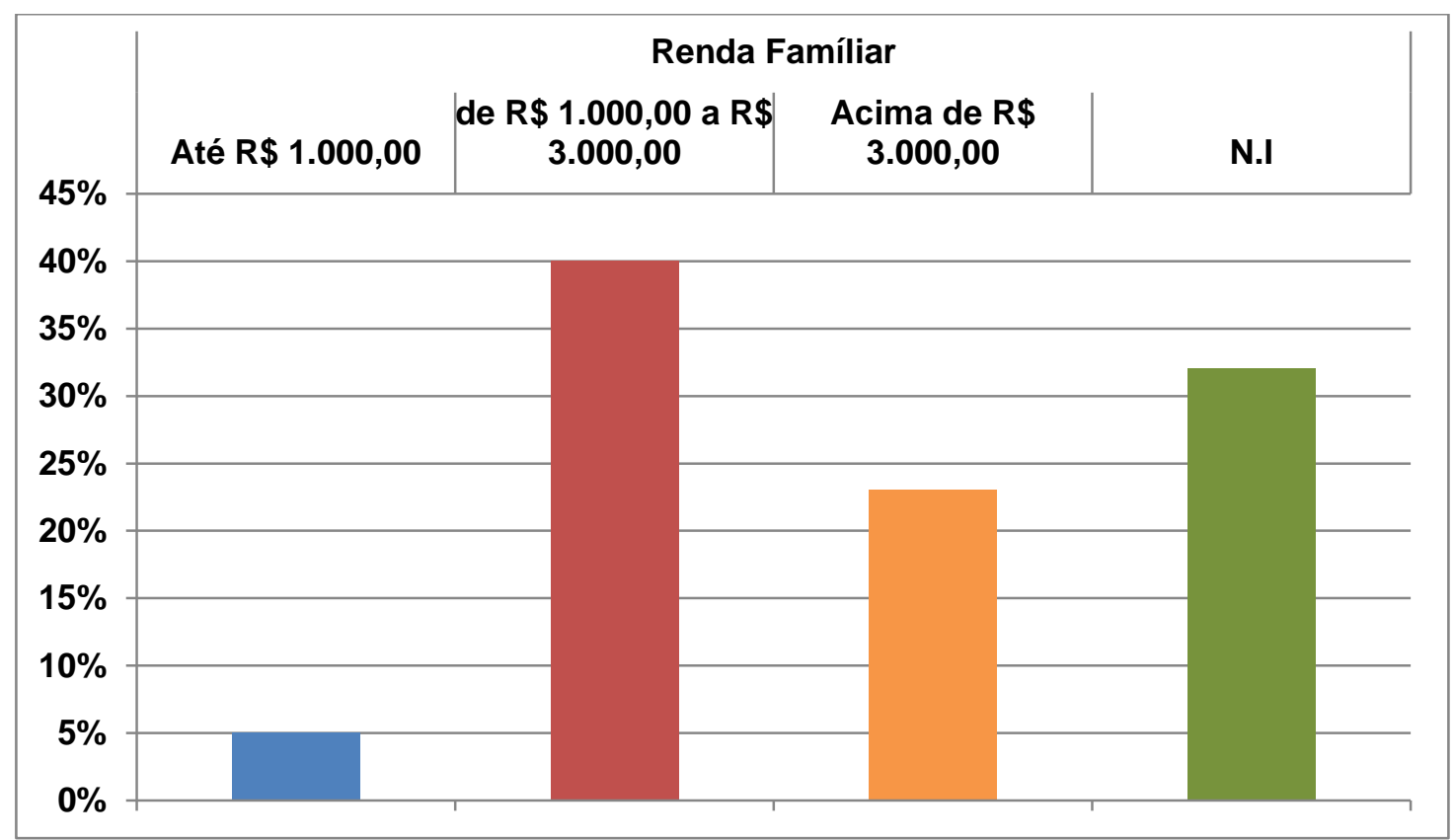


Gráfico 9 - Caracterização do quantitativo dos alunos que possuem dependente econômico

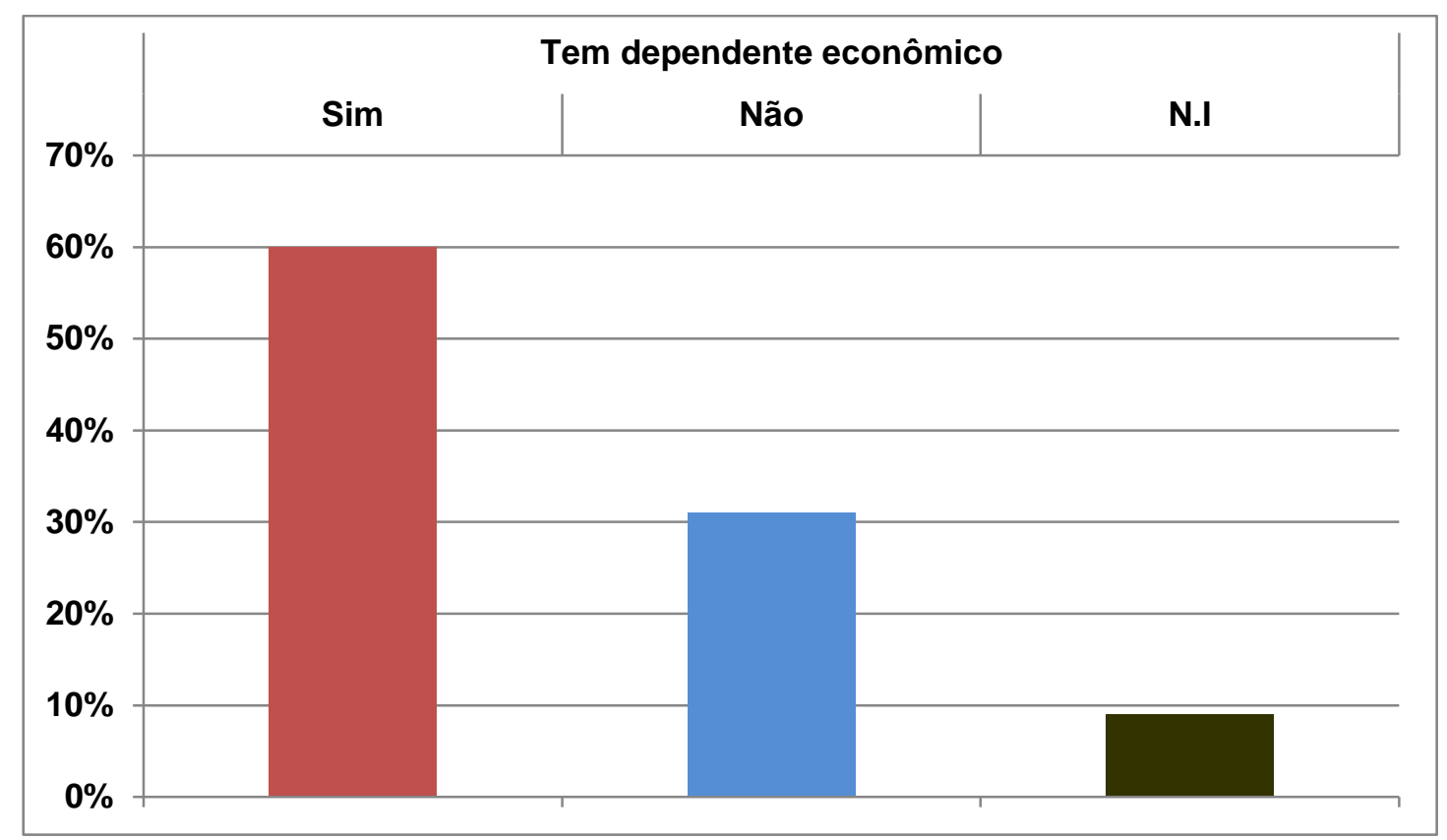

$46 \%$ dos participantes relataram que pelo menos duas pessoas da família trabalham, conforme o Gráfico 10, a seguir:

Gráfico 10 - Caracterização do quantitativo de pessoas que trabalham na família dos alunos

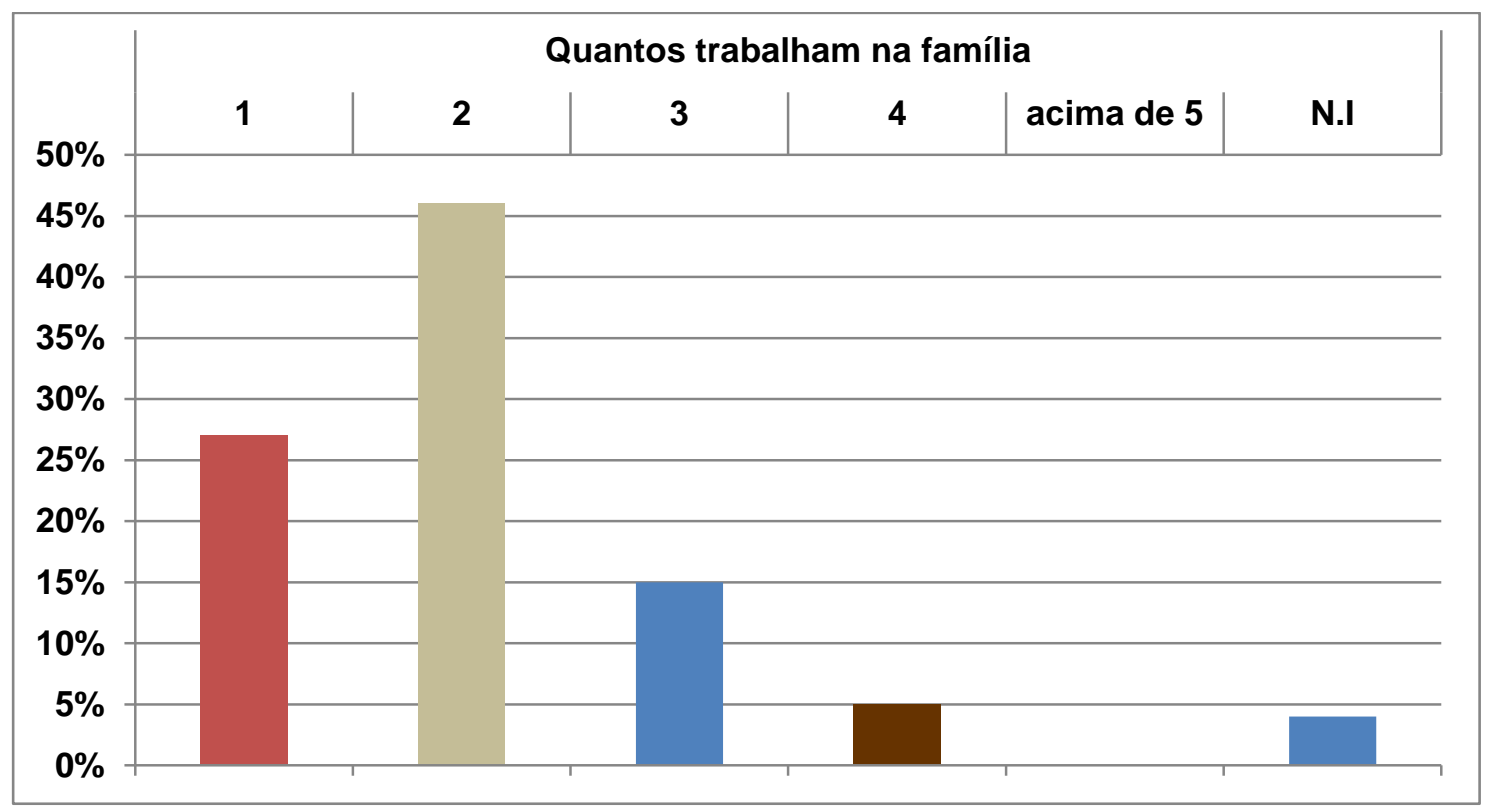


Nesse contexto é cabível considerar indícios de que o perfil dos graduandos apresentado no estado civil; na composição dos integrantes que agregam a família; na caracterização do responsável pela família, da renda familiar dos alunos, do quantitativo de dependentes econômicos e do quantitativo de pessoas que trabalham na família dos alunos, pode estar relacionado à necessidade de postergar a inserção na graduação por serem casados e, assim, possuírem obrigações familiares.

Quanto ao ensino fundamental e médio, os dados mostraram que $74 \%$ e $80 \%$, respectivamente, estudaram em instituições públicas, conforme demonstrado nos Gráfico 11 e 12.

\section{Gráfico 11 - Perfil do modelo estudantil no Ensino Fundamental de acordo com os alunos da Faculdade Particular}

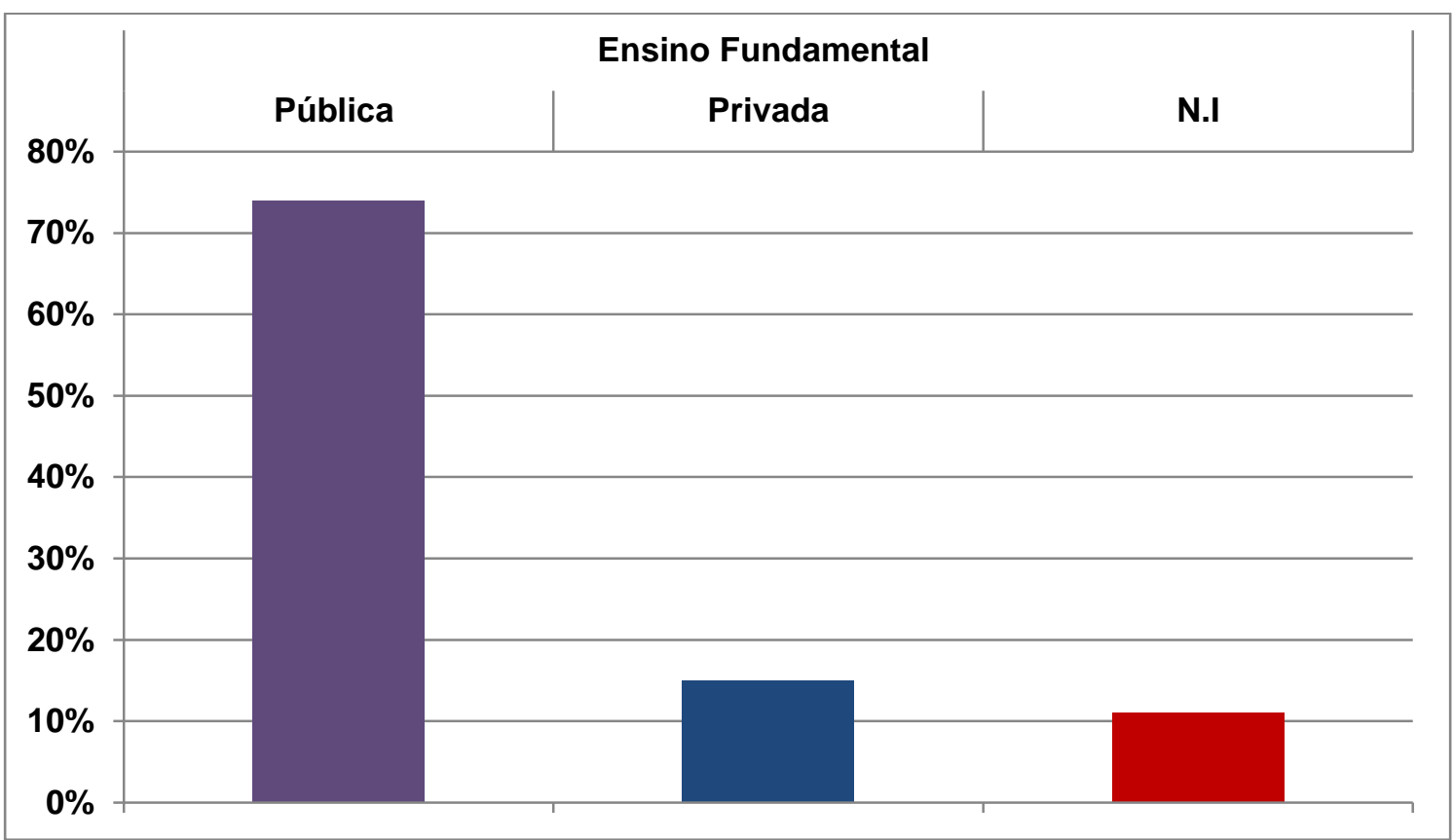




\section{Gráfico 12 - Perfil do modelo estudantil no Ensino Médio de acordo com os alunos da Faculdade Particular}

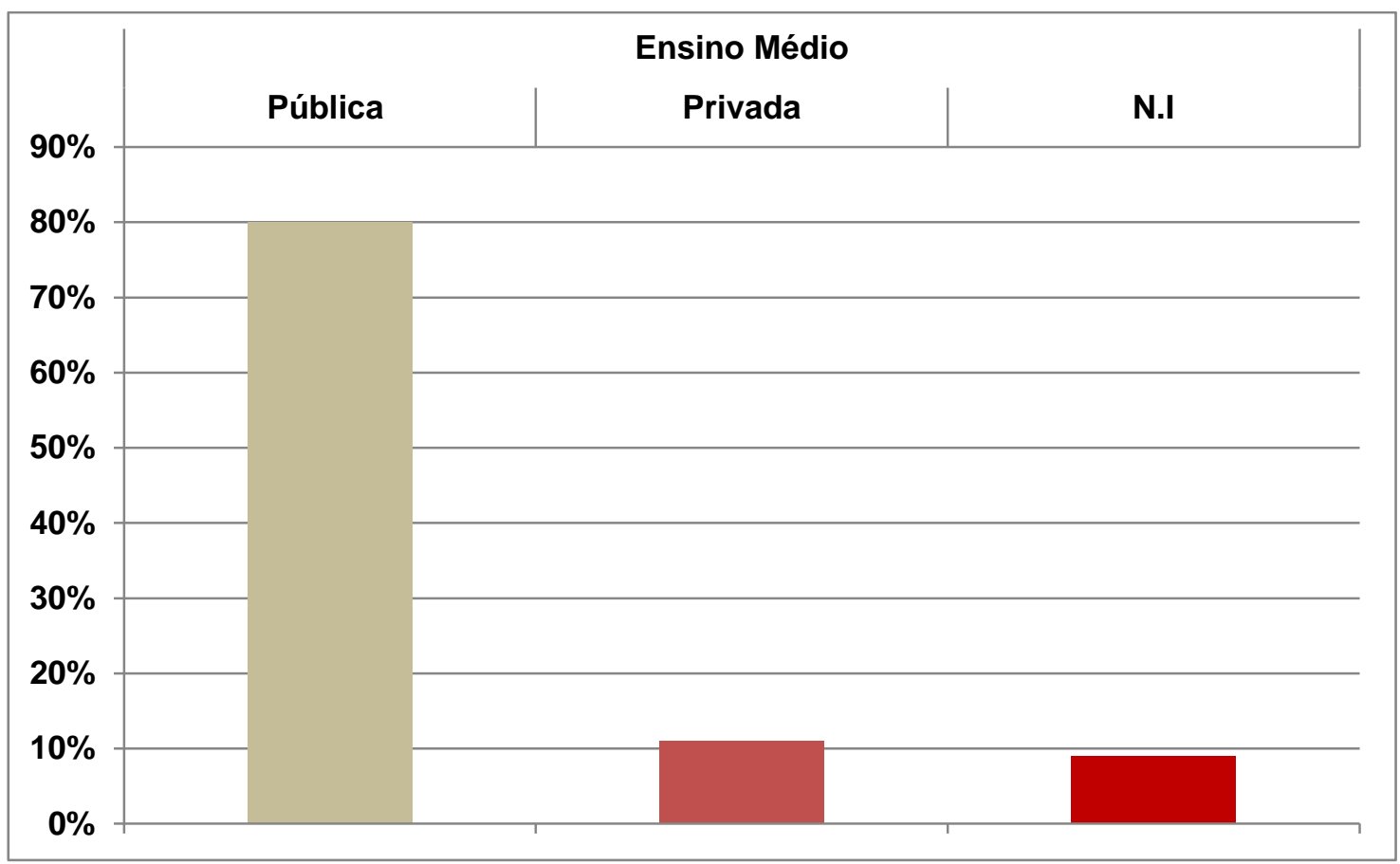

Vale ressaltar que a ampliação do acesso à educação superior, sobretudo a partir do ano 2000, no Brasil, tem permitido a inserção de grupos historicamente excluídos, principalmente nas instituições de ensino privadas, ou seja, estudantes com mais de 24 anos, população com baixa renda e estudantes provenientes de escolas públicas (Ristoff, 2014).

No relatório de 2013 realizado pelo ENADE, a maioria dos estudantes de IES privada provém do ensino fundamental e médio de escolas públicas.

Para Teixeira, Vale e Fernandes (2006b), há necessidade de revisar as políticas pedagógicas no que tange aos ingressantes ao ensino superior que cursaram o ensino fundamental e médio em escolas públicas, pois existe uma grande preocupação inerente à qualidade na assistência dos que se formarão em Enfermagem, ou seja, dos futuros enfermeiros, pois consideram preocupante a base cultural pelo cenário contemporâneo da educação nas escolas públicas no Brasil.

Em relação à bolsa estudantil, o Gráfico 13 demonstra que 63\% dos estudantes da IES investigada possuem algum tipo de bolsa estudantil. Sendo que $80 \%$ das bolsas ofertadas provêm do Fies, como apresentado no Gráfico 14. 
Gráfico 13 - Quantidade dos alunos que possuem bolsa estudantil na Faculdade Particular

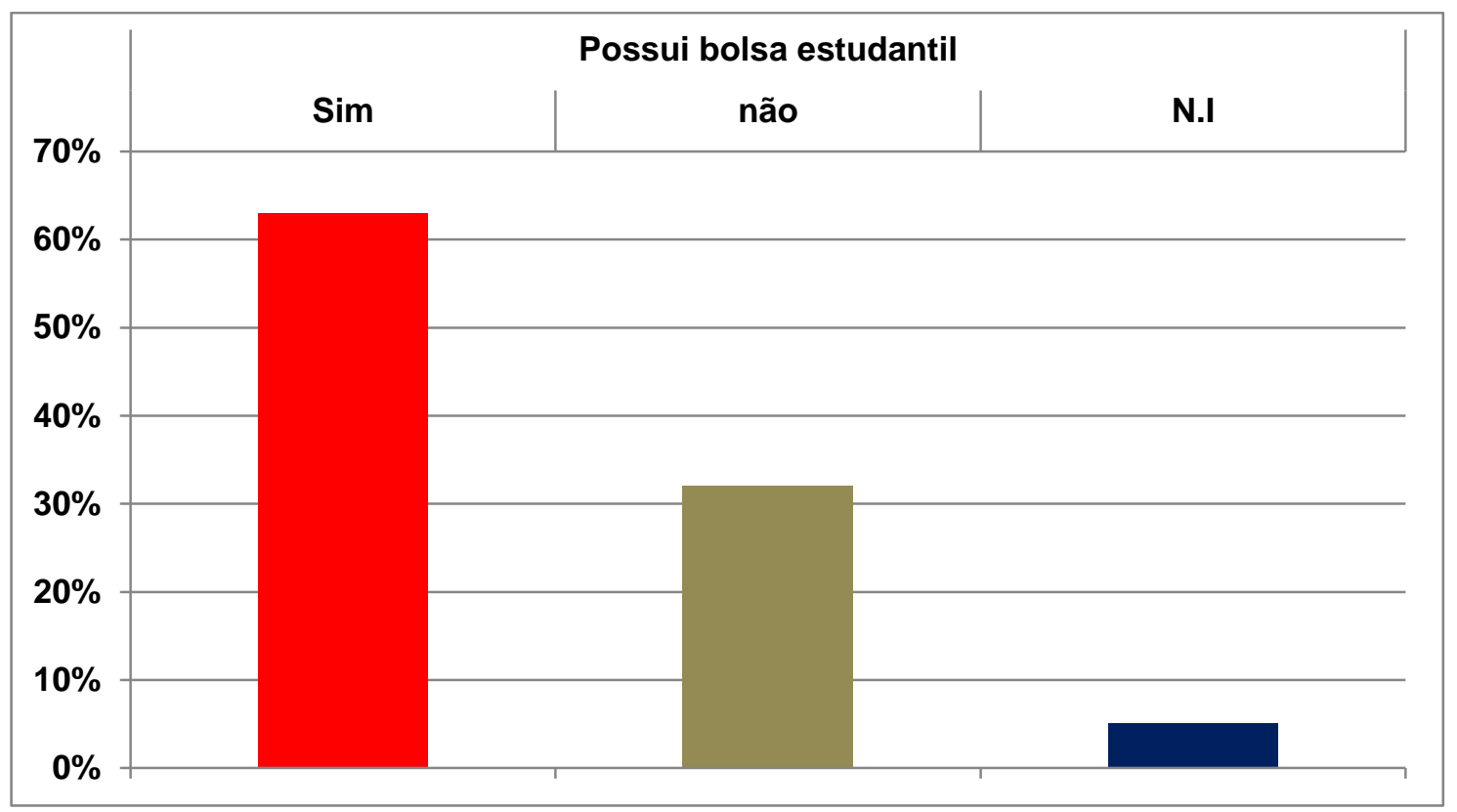

Gráfico 14 - Tipo de bolsa estudantil que os alunos possuem na Faculdade Particular

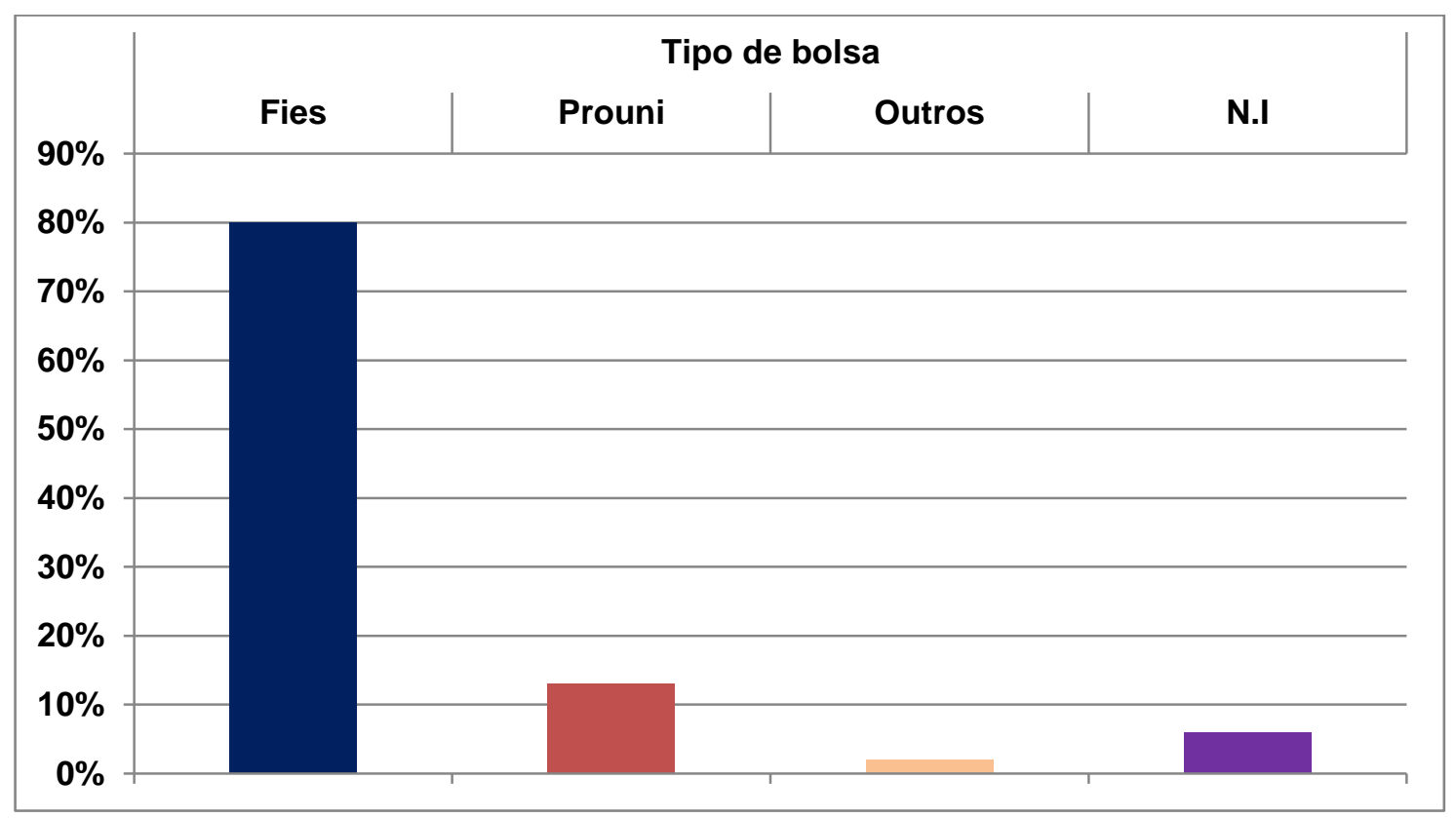

O Fies tem contribuído para a inclusão da população com diferentes perfis no ensino superior (Lima, 2013). Na IES estudada, o curso de Enfermagem é ofertado em grande escala, com o incentivo da bolsa pelo Fies. 
A amostra revelou, ainda, que a maioria dos alunos possui vínculo empregatício, correspondendo a 63\%, como demonstrado no Gráfico 15 e que 34\% desses estudantes trabalhadores possuem jornada de trabalho de até 12 horas, como revelado no Gráfico 16.

Gráfico 15 - Caracterização dos alunos da Faculdade Particular que possuem vínculo empregatício

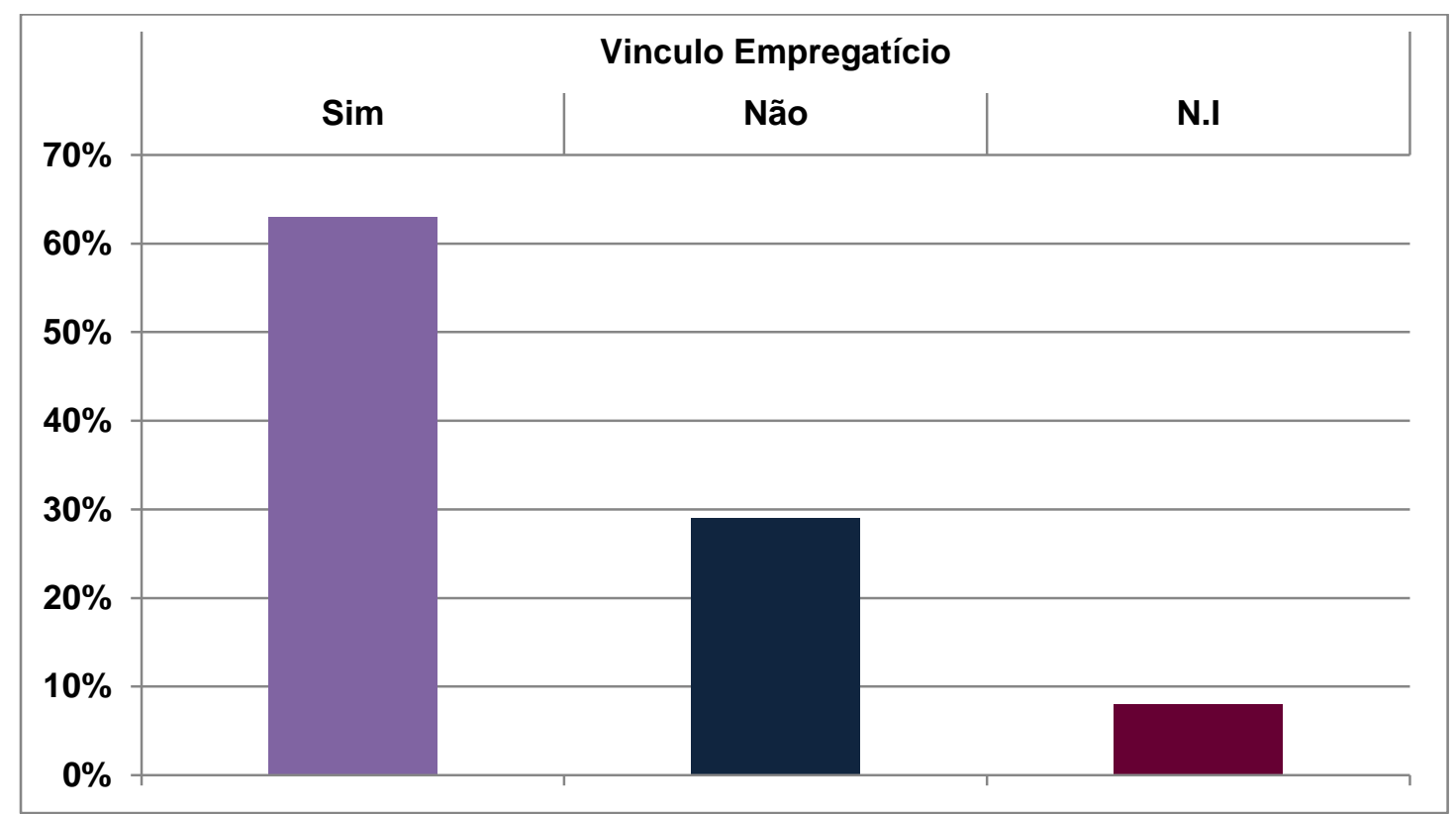

Gráfico 16 - Caracterização da jornada de trabalho dos alunos da Faculdade Particular

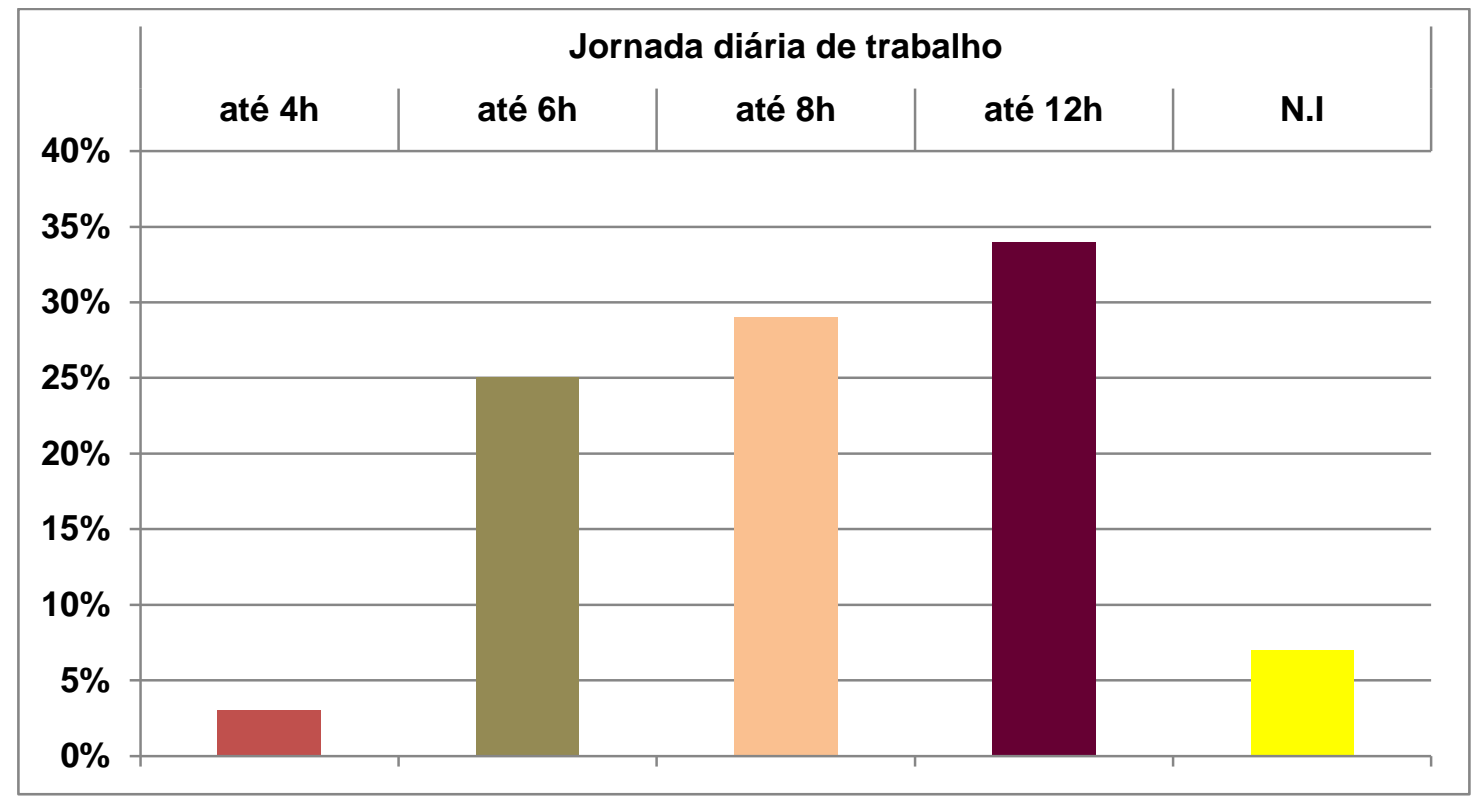


Nesse grupo de estudantes que trabalham, destaca-se que poucos exercem a profissão de enfermagem como auxiliares ou técnicos em um total de 56\% (Gráfico 17), e desses poucos que trabalham na área da enfermagem, 63\% têm mais de cinco anos na área (Gráfico 18). O Gráfico 19 revela as áreas nas quais os alunos trabalham sem ser da saúde ou da Enfermagem.

Gráfico 17 - Caracterização dos alunos da Faculdade Particular que trabalham como auxiliar ou técnico de enfermagem

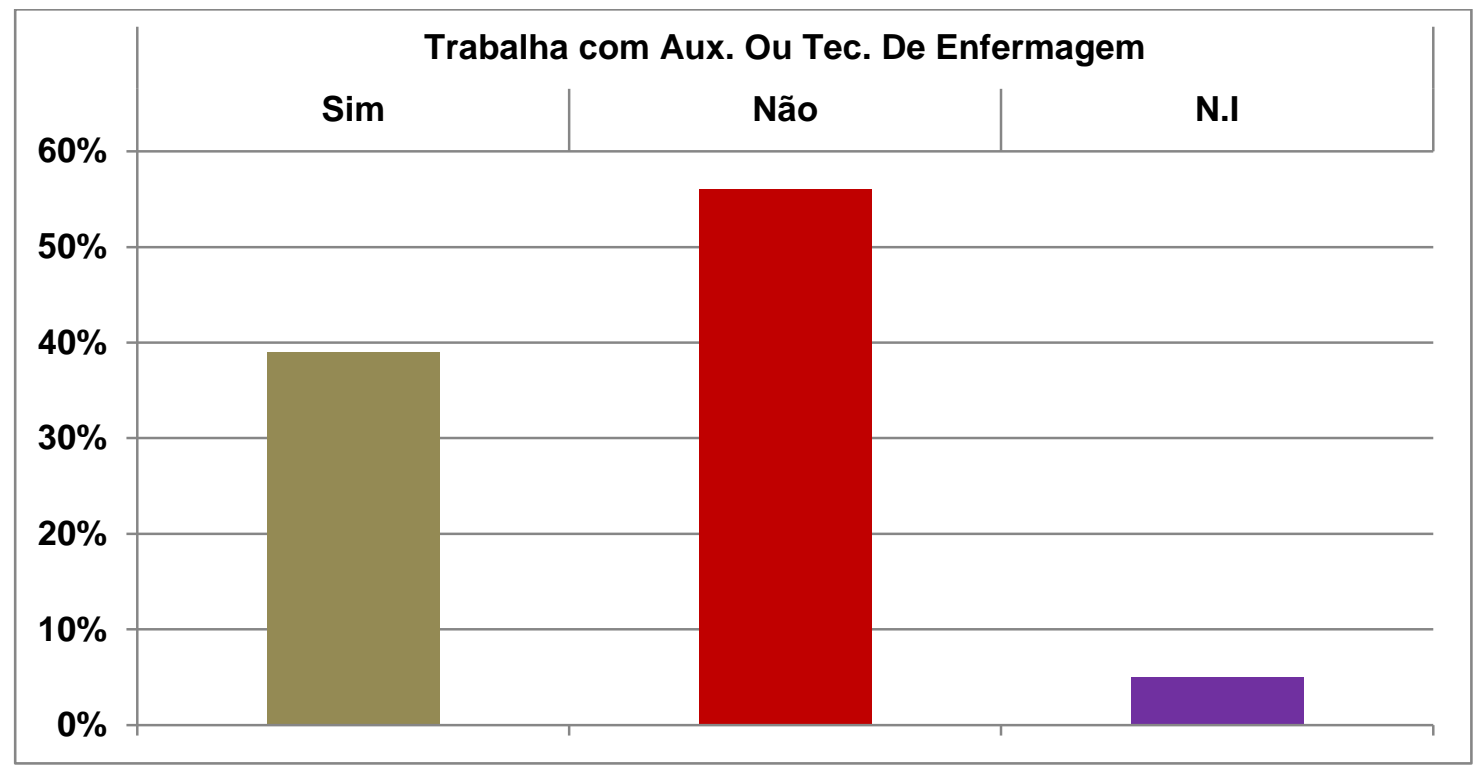

Gráfico 18 - Caracterização do tempo em anos dos alunos da Faculdade Particular que trabalham como auxiliar ou técnico de enfermagem

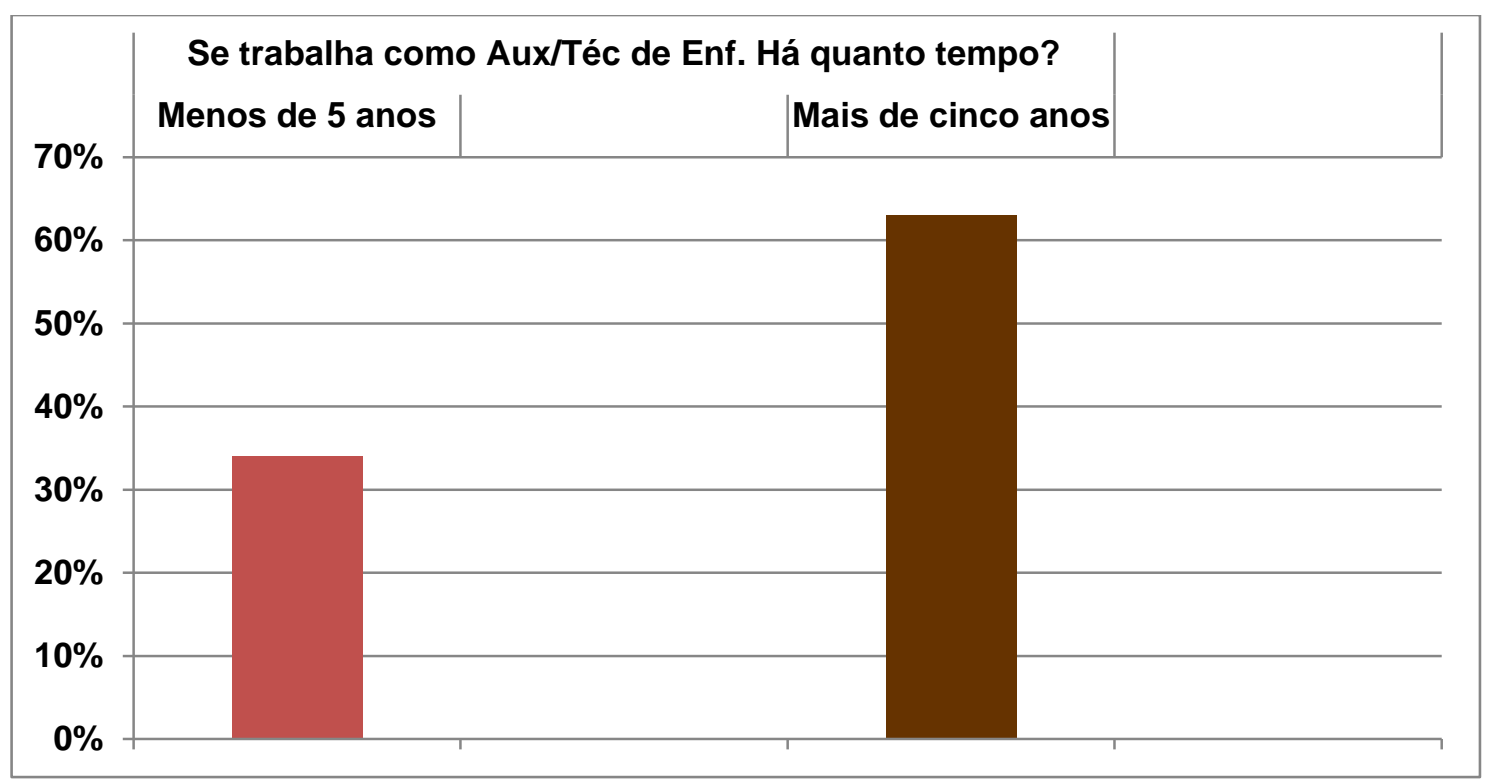


Gráfico 19 - Caracterização dos alunos que trabalham em outras áreas

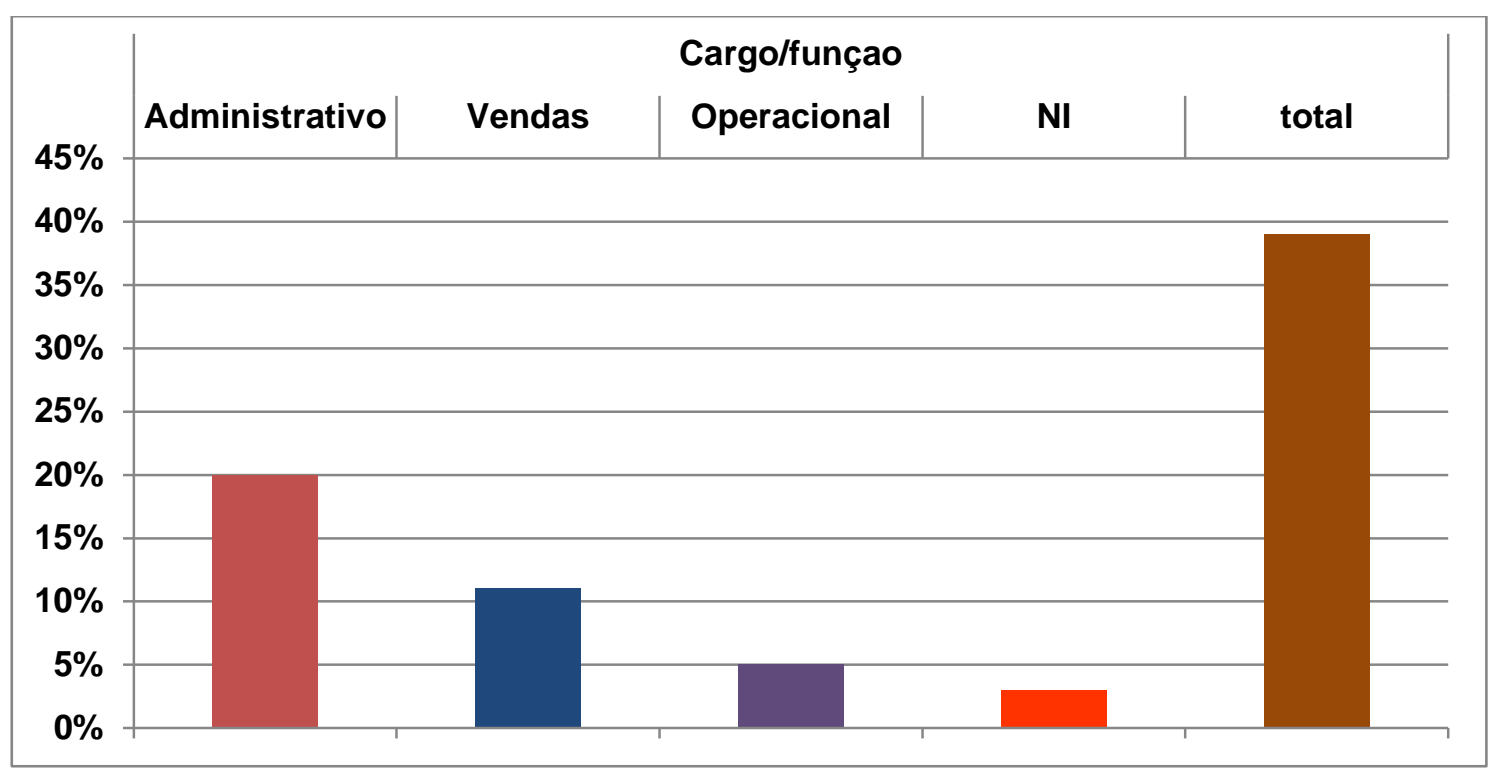

Os dados de uma pesquisa sobre o perfil dos profissionais de enfermagem brasileiros foi realizada pela Fundação Oswaldo Cruz (Fiocruz), sob o patrocínio do Conselho Federal de Enfermagem (Cofen). Tais dados foram apresentados, em 13 de agosto de 2015, na Assembleia Legislativa do Estado de São Paulo, destacandose os seguintes números: há o total de 1,6 milhão de profissionais de Enfermagem no Brasil; sendo $80 \%$ deles técnicos e auxiliares; $20 \%$ de enfermeiros (Cofen, 2015; Fiocruz, 2015).

Em relação aos dados da presente investigação, observou-se que $73 \%$ optaram pela Enfermagem como primeira escolha, como apresentado no Gráfico abaixo: 
Gráfico 20 - Caracterização da escolha profissional pela enfermagem de acordo com os alunos da Faculdade Particular

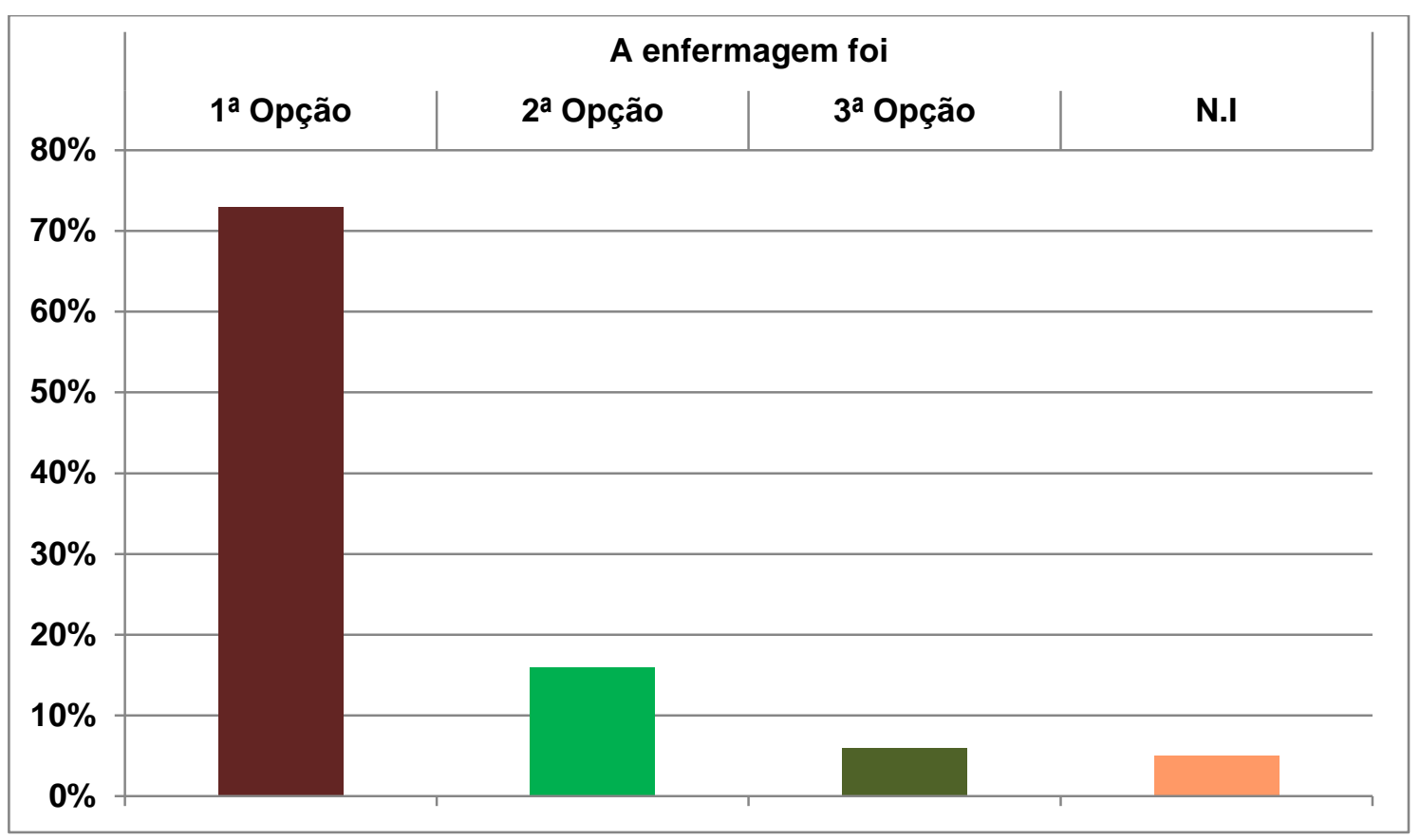

A Enfermagem vem ganhando espaço devido ao reconhecimento de suas atribuições e de seu papel perante a sociedade, "refletindo um novo status para a profissão, o que serve de estímulo para o interesse na inserção de novos profissionais no mercado de trabalho" (Brito A, Brito M, Silva, 2009, p. 329).

Por sua vez, conforme apresentado no Gráfico 21, os dados referentes à nacionalidade dos estudantes mostraram que 96\% são brasileiros provenientes de diversas regiões do Brasil, porém a maioria (58\%) se concentra na região Sudeste como apresentado no Gráfico 22. 
Gráfico 21 - Caracterização da nacionalidade de acordo com os alunos da Faculdade Particular

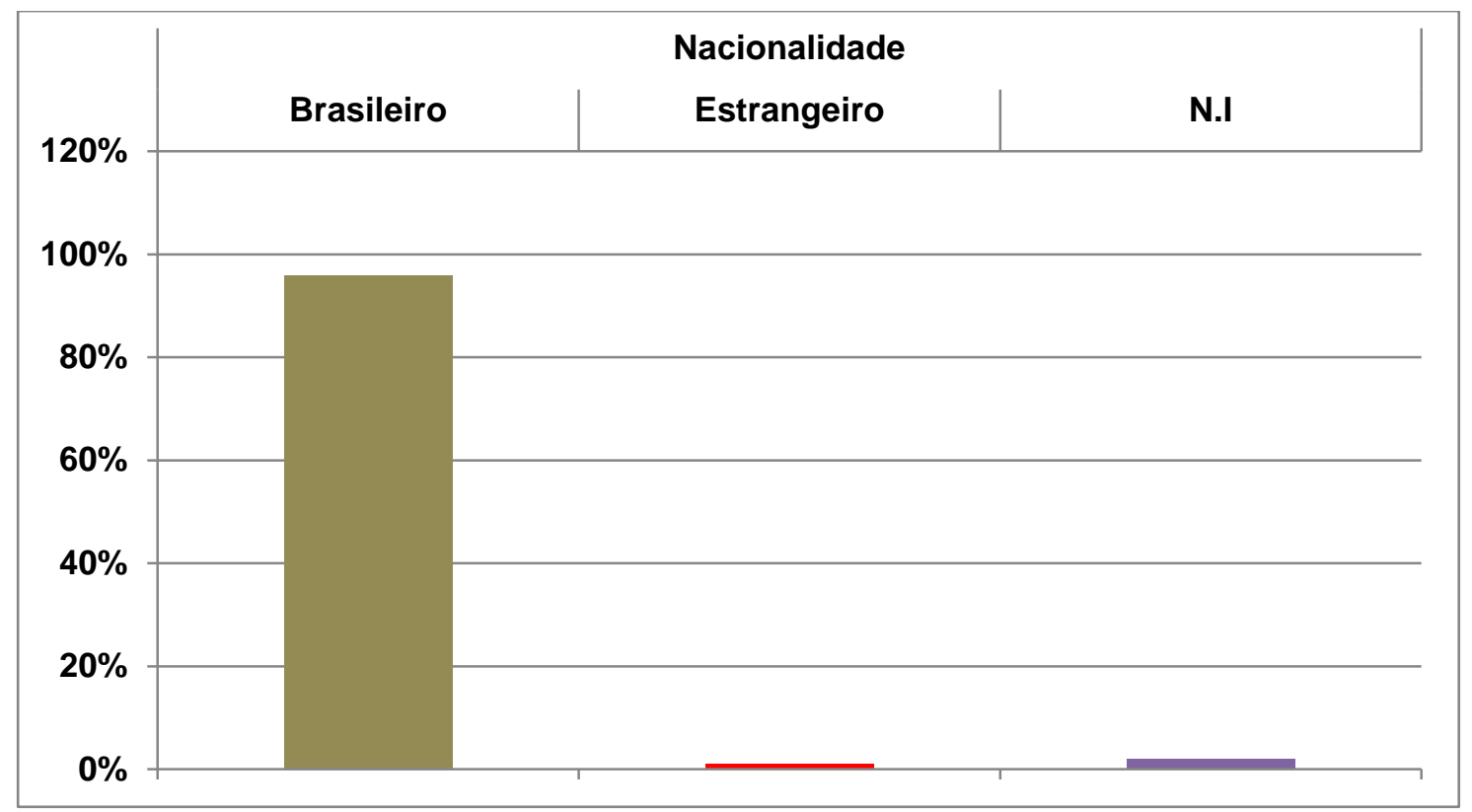

Gráfico 22 - Caracterização da procedência das regiões do Brasil dos alunos da Faculdade Particular

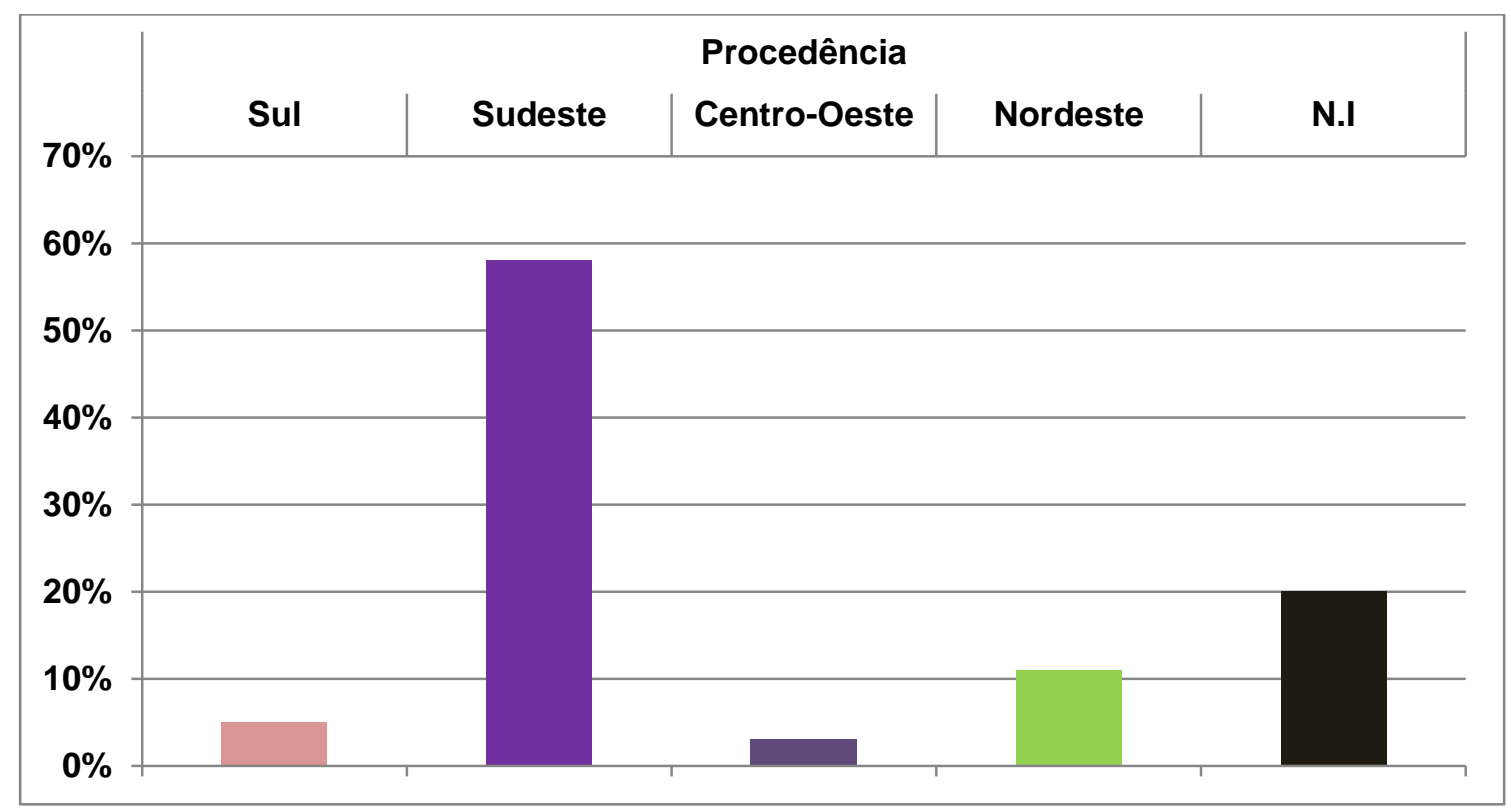

Cabe pontuar que o Enade realizado em 2013 pelos estudantes de Enfermagem, relata que "a região Sudeste apresentou o maior número de estudantes inscritos, 11.354, dos quais 10.114 (89,1\%) estudavam em Instituições Privadas" (Brasil, 2013, p. 26). 
Dentre os estudantes provenientes da Região Sudeste, a grande maioria centraliza-se na região Leste do Estado de São Paulo, correspondendo a 45\%, como revelado no Gráfico abaixo. Cabe relembrar que a IES estudada localiza-se na região Central de São Paulo.

Gráfico 23 - Caracterização da região de residência, no Estado de São Paulo, dos alunos da Faculdade Particular

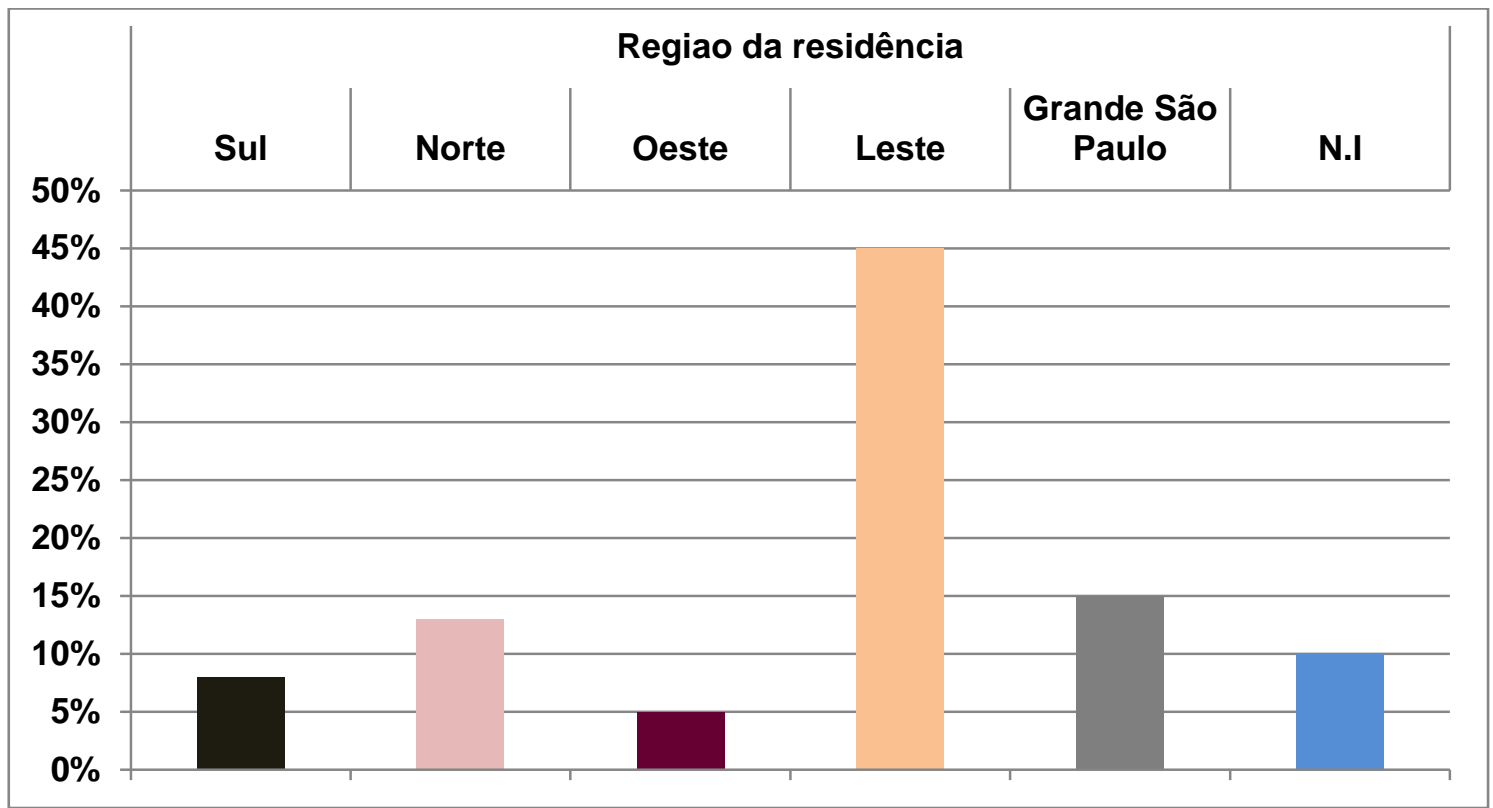

Grande parte, ou seja, 36\% levam em torno de 1 a 2 horas de deslocamento da residência até a empresa na qual trabalham (Gráfico 24) e 47\% levam, também, em torno de 1 a 2 horas da residência à faculdade (Gráfico 25). 
Gráfico 24 - Caracterização do tempo de deslocamento que os alunos levam da residência até a empresa na qual trabalham

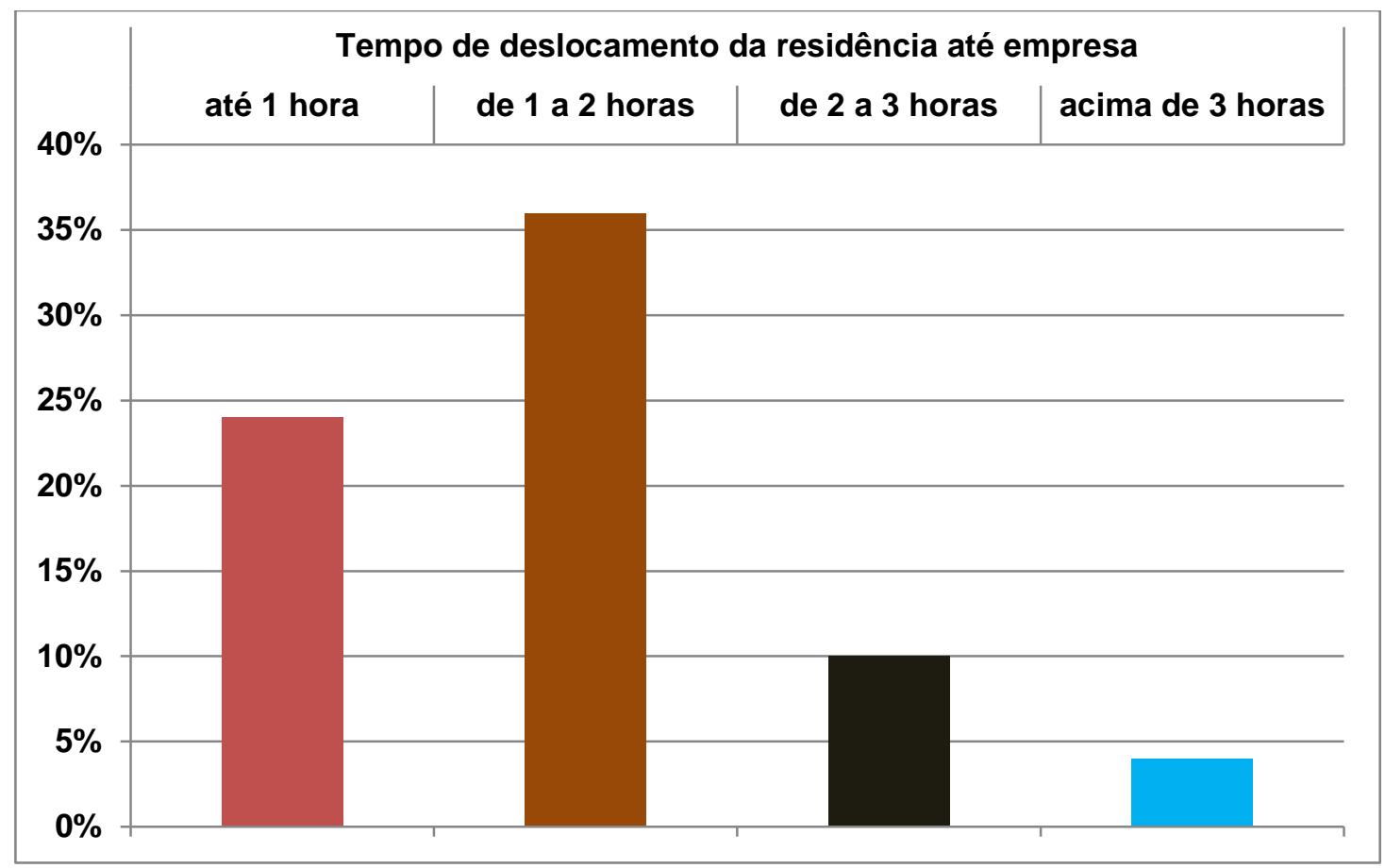

Gráfico 25 - Caracterização do tempo de deslocamento da residência dos alunos até a Faculdade

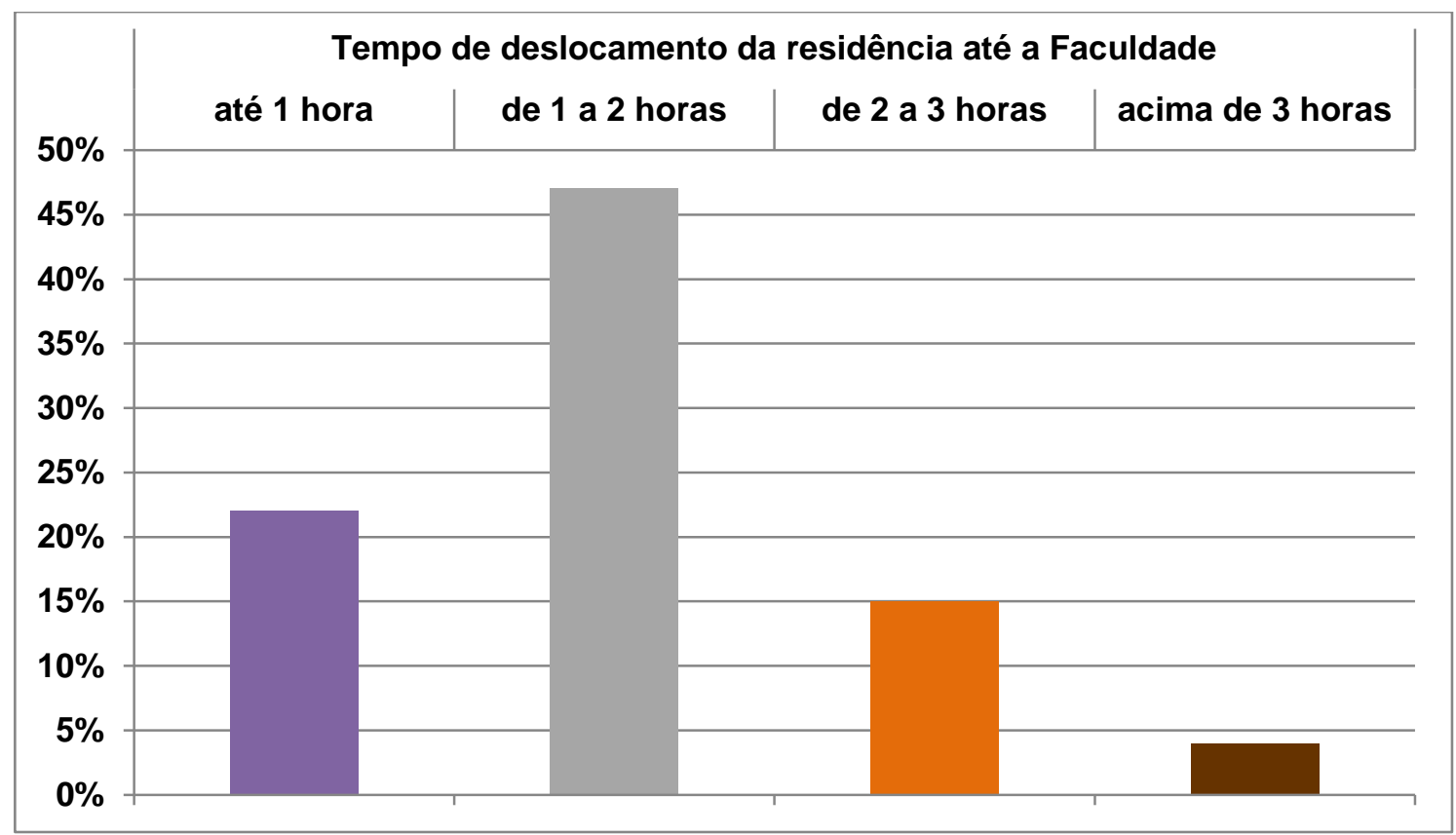

$52 \%$ dos participantes se dedicam até 5 horas às atividades acadêmicas (Gráfico 26); 26\% assistem televisão como lazer (Gráfico 27). 
Gráfico 26 - Caracterização de horas que os alunos se dedicam por semana para atividades acadêmicas

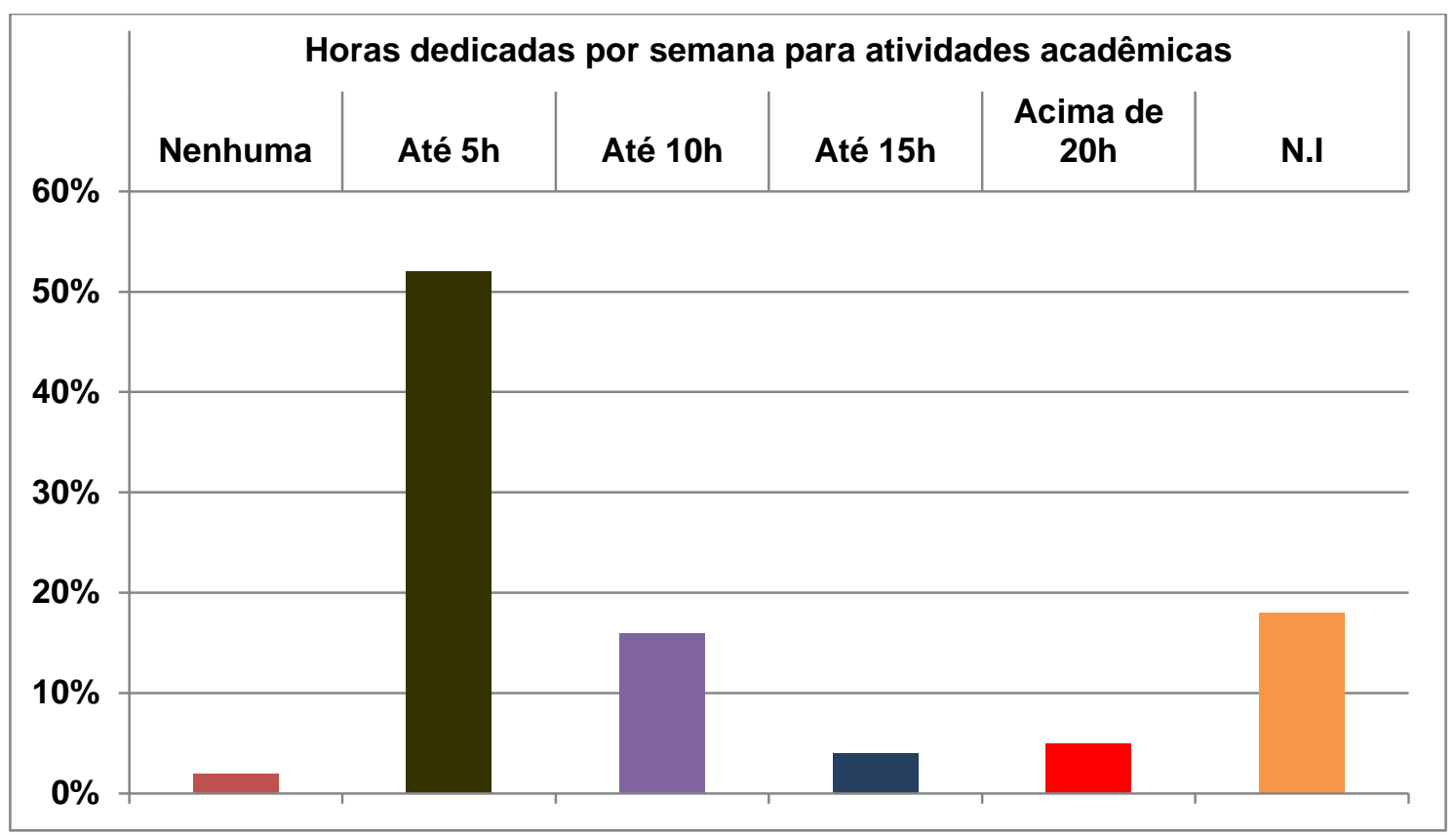

Gráfico 27 - Caracterização das atividades de lazer de acordo com os alunos da Faculdade Particular

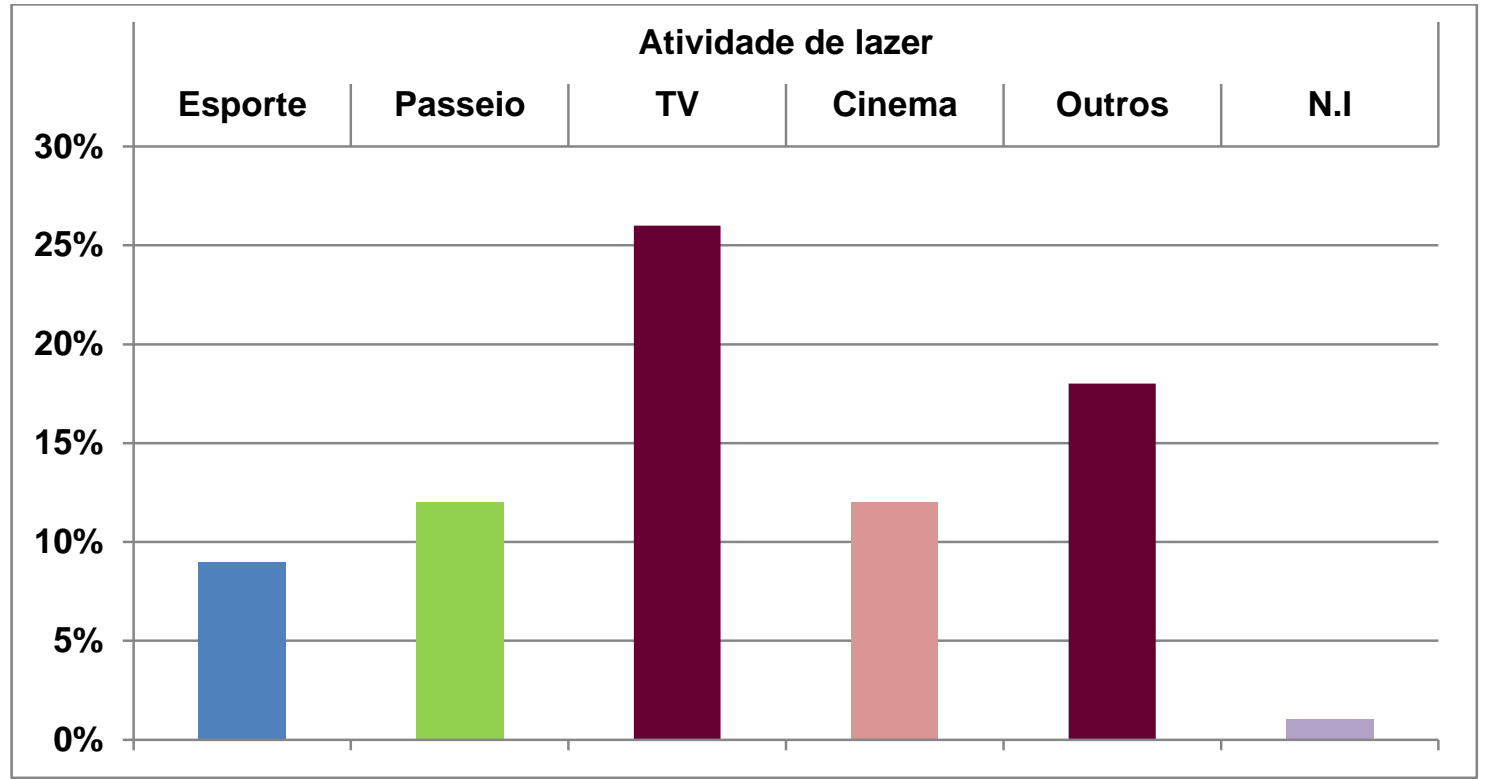

Os dados quantitativos, referentes ao perfil sócio-demográfico, respondem a parte do propósito dessa investigação, porém relativamente às questões qualitativas, outros dados empíricos foram levantados, a partir dos discursos dos participantes. 
Com isso, tornou-se possível conhecer e compreender melhor as razões das suas escolhas pela Enfermagem, possibilitando o desvelar de suas percepções ou compreensões dos significados possíveis do ser enfermeiro. Portanto, a partir do próximo tópico, apresentam-se os dados qualitativos alusivos aos discursos dos colaboradores.

\subsection{SISTEMATIZAÇÃO DOS DADOS ALUSIVOS AOS DISCURSOS DOS PARTICIPANTES DA PESQUISA}

Foram realizadas quinze entrevistas, que passaram pelo processo de transcrição e transcriação. Após esse processo, surgiram categorias e subcategorias que sistematizaram os discursos de cada colaborador.

A seguir, o Quadro 4 apresenta uma síntese dos resultados das entrevistas realizadas com os graduandos de Enfermagem. E em seguida, foram apresentados os discursos de cada categoria.

\section{QUADRO 4 - Síntese dos resultados das entrevistas realizadas com os participantes da pesquisa}

\begin{tabular}{|l|l|}
\hline \multicolumn{1}{|c|}{ CATEGORIAS } & \multicolumn{1}{c|}{ SUBCATEGORIAS } \\
\hline $\begin{array}{l}\text { Ampliando a } \\
\text { compreensão do } \\
\text { ser enfermeiro } \\
\text { (Identidade para si) }\end{array}$ & $\begin{array}{l}\text { É um profissional importante, que cuida, zela e salva vidas } \\
\text { Ser enfermeiro é doação e dedicação } \\
\text { É o profissional que cuida de forma holística } \\
\text { É o profissional que tem grande responsabilidade }\end{array}$ \\
\hline $\begin{array}{l}\text { Enfrentando os } \\
\text { desafios da escolha } \\
\text { profissional } \\
\text { (Indícios de uma } \\
\text { Identidade para o } \\
\text { outro) }\end{array}$ & $\begin{array}{l}\text { Enfermeiro como missionário do cuidado } \\
\text { Empregabilidade } \\
\text { Profissional que trabalha excessivamente } \\
\text { Enfermeira como representante da mulher de vida fácil } \\
\text { Profissional não reconhecido } \\
\text { Profissional mal remunerado }\end{array}$ \\
\hline $\begin{array}{l}\text { Construindo o } \\
\text { processo de } \\
\text { socialização no } \\
\text { contexto da escolha } \\
\text { profissional }\end{array}$ & $\begin{array}{l}\text { Experiência de ter vivenciado uma situação de necessidade } \\
\text { de saúde na família } \\
\text { Já ser profissional da área da Enfermagem atuante ou não } \\
\text { Ter tido contato com profissionais da Enfermagem }\end{array}$ \\
\hline
\end{tabular}




\begin{tabular}{|l|l|}
\hline Projetando o futuro & Aceitação, respeito, valorização, reconhecimento da profissão \\
profissional & Compromisso, interação e o cuidado \\
& Estar estável financeiramente \\
& Realização de um sonho no presente momento projetado ao \\
& futuro \\
& Trabalhar em uma área específica da Enfermagem \\
& relacionada às necessidades \\
& pessoais vivenciadas no momento presente \\
Mudança no comportamento
\end{tabular}

\subsubsection{Categorização dos discursos}

Para assegurar o anonimato dos participantes da pesquisa, eles foram identificados pela letra $\mathbf{P}$ seguida do número correspondente, de 1 a 15.

Foram criadas quatro categorias: ampliando a compreensão do ser enfermeiro; enfrentando os desafios da escolha profissional; construindo o processo de socialização no contexto da escolha; projetando o futuro profissional.

\section{Categoria 1 - Ampliando a compreensão do ser enfermeiro (Identidade para si)}

A categoria "Ampliando a compreensão do ser enfermeiro" retratou a percepção dos participantes em relação ao profissional enfermeiro como um indivíduo em sociedade, exteriorizando uma identidade pessoal e profissional percebida para si. Assim, essa identidade foi traduzida em cinco tópicos (a-e):

a) É um profissional importante, que cuida, zela e salva vidas

Ser enfermeiro para mim é uma honra (...). É ter uma consciência, de poder cuidar do próximo, ter amor, ter zelo, responsabilidade acima de tudo e honrar aquilo que você faz à pátria (...) (P1).

Pra mim é um área muito ampla, porque além de você cuidar, você zelar pela vida de um paciente, você salva. (...). É um conceito de vida. É você gostar de simplesmente ajudar (P3).

É basicamente cuidar. Você tem que amar a profissão. Não adianta você fazer e não gostar, por dinheiro. Sei que enfermagem não da dinheiro, você tem que amar (P4). 
Ser enfermeiro para mim é ter amor à vida. Amar a profissão. Ter amor ao próximo. Você querer ver o bem do próximo (P5).

Salva vida (P6).

O enfermeiro é uma pessoa muito importante para a sociedade, algo que não pode faltar, tudo mundo precisa (P12).

Cuida do próximo (P13).

O enfermeiro acaba sendo o porto seguro daquela pessoa que está necessitando de cuidado (P14).

\section{b) Ser enfermeiro é doação e dedicação}

É poder se doar total para ajudar outras pessoas. Ter dedicação (P9).

Ser enfermeiro pra mim é doar uma parte de si do seu tempo. Dedicar ate mesmo para um ser humano desconhecido (P10).

c) É o profissional que cuida de forma holística

Enfermeiro pra mim não é somente cuidar de pessoas, é lidar com vidas, com os sentimentos das pessoas, porque quando a pessoa quando chega no hospital, chega debilitada mentalmente, em vários sentidos. Em minha opinião ser enfermeiro é você cuidar de um todo da pessoa, tanto da parte física, quanto da mental do paciente (P8).

d) É o profissional que tem grande responsabilidade

Ser enfermeiro é uma responsabilidade muito grande, é a satisfação de você ver a saúde do paciente, o desenvolvimento dele, a evolução dele (P11).

O enfermeiro é uma das partes mais importantes na área da saúde, ele é a peça-chave do quebra cabeça, ele tem grande responsabilidade (P15).

\section{e) É o profissional que tem poder}

Sempre tive uma figura muito distorcida do enfermeiro, como um mandão, um chefão, digamos assim, o vagabundo do hospital. (...). O enfermeiro quando se forma, eu acho que sobe um pouco pra cabeça dele. Parece que o grau de superioridade dele se eleva um pouco, então, ele passa a tratar o auxiliar e o técnico um pouco meio que, como se fosse o faxineiro dele. (...). Eu falava que ia fazer a diferença, que eu não ia fazer aquilo. Ate hoje eu 
tenho uma chefe e ela olha pra gente como se a gente fosse inferior a ela, por ela ser enfermeira, onde eu trabalho (P7).

\section{Categoria 2 - Enfrentando os desafios da escolha profissional (Indícios de uma identidade para o outro)}

Esta seção trata dos indícios relacionados à identidade para o outro sob a visão dos graduandos e traz resultados do questionamento feito aos participantes da pesquisa sobre aceitação ou negação da escolha profissional pela Enfermagem.

No tocante à opção pela profissão da Enfermagem, apenas duas categorias puderam ser categorizadas de forma positiva, segundo o discurso, sob a perspectiva dos familiares dos participantes, sendo elas:

a) Enfermeiro como missionário do cuidado

Eles veem o enfermeiro como um missionário do cuidado ao próximo, sendo considerada uma área gratificante (P5).

b) Empregabilidade

Minha mãe sempre insistiu muito pra eu fazer o curso de enfermagem, alegando ser uma área boa, que tem emprego (P14).

Diferentemente, as falas a seguir demonstram a dificuldade da aceitação pelos familiares e/ou amigos, por diversos motivos dos quais foram subcategorizados da seguinte forma para melhor compreensão e visualização:

a) Profissional que trabalha excessivamente

Quando resolvi fazer a faculdade de enfermagem, uns falaram: "Que loucura! Depois que você começou a fazer enfermagem, mal tem tempo para nós" (...). Tive outros amigos/famílias que disseram: "Você tá doida, você vai fazer enfermagem? Por que você não escolhe psicologia? Por que você não escolhe outra área? Você vai ficar praticamente num plantão doze horas. E seu noivo? Futuramente você vai casar. Sua mãe?" (P1).

Por mais que alguns falem "Ah, isso não é vida! Plantão de doze horas! Vira muito tempo. Você não tem tempo pra sua família! Você vai querer uma família no futuro?". Eu acho que o que importa é o que a gente pensa (P3). 
b) Enfermeira como representante da mulher de vida fácil

No momento da escolha pela faculdade de enfermagem, foi difícil porque a gente sendo mulher chegar para o marido e falar que vai estudar e dizer: "Vou ser enfermeira". Tem aquela coisa do mal visto, infelizmente tem, não é conversa fiada, porque tem mesmo. (...). No sentido da pornografia (P2). Quando comecei a faculdade de enfermagem, eu era casada quando eu comecei o curso e meu marido não aceitava, dizia que enfermeira era "lanche" de médico (P13).

\section{c) Profissional não reconhecido}

Os amigos do meu serviço falaram que eu era louca, que não era uma área muito legal. Minha escolha não foi pensando no dinheiro, porque não tenho noção de ganhos de enfermeiro. Foi realmente por amor que começou com minha tia e foi aí que eu decidi. Minha família, a única que aprovou essa decisão, foi minha mãe. Meu pai, meu irmão e minha irmã, não aprovaram. Falam que essa área não é boa, não é reconhecida. Não é uma área que você olha e fala "essa pessoa é reconhecida por ser formada nisso" (P8). Minha mãe dizia: "É isso mesmo que tu quer?. Porque é uma área que tem muitas portas para entrar, mas não é uma área reconhecida como deveria (P9).

d) Profissional mal remunerado

Os próprios colegas da regulação foram contra. Muitos, muitos, não foram duas/três auxiliares, muitos que falavam: "Ah enfermagem? Vai fazer engenharia que dá dinheiro. Advocacia que dá dinheiro". Não, eu vou fazer enfermagem, não sei fazer outra coisa (P7).

Os vizinhos falam e os amigos meus: "Nossa! tanta coisa pra você fazer, você vai enfermagem? Não dá dinheiro!” (P12).

\section{Categoria 3 - Construindo o processo de socialização no contexto da escolha profissional}

Essa categoria trouxe a compreensão do motivo da escolha da profissão no processo de socialização.

a) Experiência de ter vivenciado uma situação de necessidade de saúde na família

Escolhi essa profissão, primeiro de tudo, para ajudar o próximo, para eu poder ser útil dentro do meu lar, no meio dos meus familiares, poder ajudar meus vizinhos, e enfim, ajudar uma sociedade que precisa de bons 
profissionais qualificados. Escolhi, também, porque tenho uma mãe que é idosa e ela tem problema de pressão, é hipertensa. Assim, devido a idade e por ela passar mal, escolhi ser enfermeira para poder ajudá-la, porque posso utilizar essa profissão, então, vou ser útil dentro da minha casa mesmo. Passei por dificuldades dentro do meu lar. Perdi algumas pessoas que eu não pude ser útil, porque eu não tinha conhecimento da enfermagem (P1).

Quando eu resolvi ir mesmo para enfermagem foi há oito anos. Meu pai faleceu em casa. Ele nunca teve problema de saúde. Nunca o vi doente. Ele nunca bebeu, nunca fumou. (...)Num sábado ele foi dormir e não acordou. (...). Chamei o SAMU. (...). Eu não era auxiliar ainda. (...) Fui gostando mais ainda quando eu tive meus bebês, tinha que levar no hospital, ficar na internação. Via todos aqueles cuidados de enfermagem e aquilo me atraía demais ver o cuidar, o zelo (P2).

Em 2010, minha mãe teve um AVC. Eu estava no hospital. Vi o enfermeiro, o médico consultando como se fosse uma pessoa qualquer. Falei pra minha mãe "Quero ser enfermeiro" (P4).

Meu namorado entrou na vida errada, terminei o namoro. Depois de 8 meses que não estávamos mais juntos, ele levou um tiro na cabeça. Ficou entre a vida e a morte. (...). Ele não comia. Até o remédio tinha que amassar. Minha sogra trabalhava em um hospital. Como ela não ficava o período todo em casa, tinha que ajudá-la. Ele veio para casa parecendo...sei lá, ele não andava, não comia, nem falava direito. Foi muito difícil. Foi um ano mais ou menos pra recuperar. Eu fui acompanhado isso, ajudando. Quando ele andou de novo, parecia um bebê. Foi daí que eu fui pegando amor pela área da saúde (P5).

Há uns 15 anos minha sogra fez uma cirurgia de pedra na vesícula. Foi pra casa com um dreno. Não sei como, mas entupiu aquele dreno. Ela ficou mal. Foi as pressas ao hospital e ficou internada por 6 meses na UTI e quarto. Quando ela ia para o quarto eu ficava com ela. Via as enfermeiras cuidando. Eu falava "Meu Deus é isso que quero fazer!" (P6).

Sempre estive no meio da enfermagem, minha filha teve câncer aos 6 anos. Meu filho está 10 anos, mas sempre teve bronquite, sempre ficou internando (P7).

Quando decidi, definitivamente, ingressar na faculdade de enfermagem, foi quando minha tia teve um câncer. Para ela se alimentar e ser medicada tinha que ser por sonda. Ninguém da minha família tinha coragem de dar alimento pra ela pela sonda. A única pessoa que tinha coragem de ajudar ela, de limpar, porque às vezes aparecia ferida, a única pessoa de que tinha coragem de estar ali com ela era eu (P8).

Quando realmente eu vi que queria fazer enfermagem foi quando meu pai precisava de ajuda e eu não sabia fazer. Eu pensava "Nossa se eu soubesse, eu poderia fazer, ao invés de esperar de outras pessoas" (P9). 
Eu fiquei com minha avó que ficou internada um bom tempo. Vinham os enfermeiros e eu ficava observando o cuidado (P10).

O processo de escolha da enfermagem começou quando eu descobri que eu era diabética, tinha 19 anos (P11).

Meu pai tinha sofrido um acidente e ficou 6 anos paraplégico, acamado, com várias úlceras por pressão pelo corpo. (...). Conseguimos curá-lo porque procuramos orientações dos enfermeiros do posto de saúde. (...). Pensei: "Acho que vou fazer enfermagem". Não fiz auxiliar/técnico de enfermagem entrei direto na faculdade (P15).

\section{b) Já ser profissional da área da Enfermagem atuante ou não}

Iniciei trabalhando em uma clínica geriátrica que estou até hoje. Ali, fui pegando gosto, amor. Cuido de dezoito pacientes com problema de Alzheimer, AVC e Parkinson. Elas têm idade de ser minha avó, eu tenho idade de ser neta delas. Cuido delas como se cuidasse da minha própria mãe da minha própria avó (P1).

Foi passando o tempo, fui trabalhando em casa de repouso. Me identifiquei com a área geriátrica, gosto muito dessa área. Eu não gostava, por incrível que pareça, de lidar com gente de idade (...),meu marido ficou desempregado e eu tinha que trabalhar. (...). Uma amiga falou: "tem uma casa de repouso que está precisando de uma auxiliar". Eu pensei: "casa de repouso?!", mas a necessidade faz o ladrão, então, fui. Na segunda semana já estava apaixonada por aqueles idosos. Mudei totalmente minha visão em relação a eles e à família deles (P2).

Comecei o auxiliar com dezesseis anos, mas abandonei o curso depois que tive um trauma no estágio. Perdi uma paciente que eu me apeguei muito a ela. Ela sofria demais, demais. Quando ela faleceu, infelizmente eu não estava no hospital, porém, na noite anterior ela pediu para que eu ficasse, porque ela não tinha ninguém. Saí do plantão de estágio, liguei para os meus pais e falei que ia passar a noite inteira com ela. Fiquei a noite com ela e ela me disse que sabia que no dia seguinte ela ia morrer. Abandonei o curso faltando um mês para concluir. (...). No ano seguinte retomei tudo de novo, comecei do zero, comecei mais forte. (...). Passei por outra coisa. Paciente psiquiátrico. Fui dar banho nele. (...).Todo mundo me falou que ele não gostava de tomar banho, mas ele parecia ser muito dócil, ele era enorme. Simplesmente falei: "Vamos tomar banho". Ele foi comigo e disse: "Mas não quero tomar banho", eu falei "Vamos tomar banho. Banho é bom, é gostoso!" E a gente foi para o banheiro. Quando ele começou a tirar a roupa, colocou as mãos no meu pescoço e me enfiou debaixo do chuveiro. Ele me deu um banho (suspirou sorrindo). (...). Fui embora, deixei, mas não parei. Eu já tinha parado uma vez, e decidi não parar. Decidi continuar (P3).

Na verdade quando eu comecei a fazer o auxiliar, falei: "Acho que não é isso que eu quero pra mim" (P12). 
c) Ter tido contato com profissionais da Enfermagem

Em 2003 eu namorava uma menina eu tava no colégio. Ela fazia enfermagem em uma faculdade (...). Eu era novo, tinha 14 anos e ela tinha 21 e tava terminando a faculdade. Eu a ajudava nos trabalhos, porque sempre gostei de pesquisar. Como a gente não tinha tempo junto, a matéria que ela tinha necessidade de fazer, eu fazia para ela. Comecei pegar gosto pela enfermagem (P4).

Minha mãe parou de estudar (...). Como ela trabalhava e ia direto para 0 curso, eu ajudava ela a fazer os trabalhos. (...). Fui me interessando a partir daí (P5).

Sempre tive vontade de fazer enfermagem minha irmã mais velha fez, ela conseguiu e eu tava ficando pra trás. (...). Minha irmã mais velha se aposentou. Trabalhou mais de 30 anos no Emílio Ribas, ela fez o auxiliar e o técnico de enfermagem (P6).

Tinha um professor que todo dia ia de branco (...). Então, perguntei "Professor, o que o senhor faz?" Ele falou "Eu sou enfermeiro". Perguntei "O que é ser enfermeiro? Ele falou "É bacana! Por que você ta perguntando?" Eu respondi "To pensando no que vou fazer". Ele me disse pra eu fazer um curso técnico que daria pra eu ter uma ideia do que era a área da saúde. Ele dizia que muita gente escolhia a área da saúde por causa do pai, da mãe, dos tios (P13).

Minha mãe é técnica de enfermagem e falava que eu levava jeito (P14).

\section{Categoria 4 - Projetando o futuro profissional}

Esta subcategoria demonstra a projeção do futuro da profissão de Enfermagem e do graduando, participante dessa pesquisa, no que tange à visualização do seu futuro como profissional inserido nessa área.

a) Aceitação, respeito, valorização, reconhecimento da profissão do enfermeiro

Espero um futuro melhor, uma enfermagem mais aceita, respeitada $(\mathrm{P} 1)$.

Espero que a enfermagem seja mais reconhecida, já mudou bastante. $\mathrm{O}$ reconhecimento seria na diferenciação do enfermeiro, do técnico e do auxiliar (P5).

Espero que seja uma área mais reconhecida, não somente para os enfermeiros, mas para os técnicos e auxiliares (P8). 
No futuro, para a área da enfermagem, espero melhorias, pois há muitos enfermeiros que se dedicam e não têm valor, (...).Que o ser humano entenda qual é a função do enfermeiro no hospital. Se pudesse, deveria ter palestras nos hospitais, explicando a função do enfermeiro. (...). Que as pessoas respeitassem a posição de cada um no hospital, principalmente os pacientes (P10).

A gente sabe que o enfermeiro não recebe muito bem, acaba trabalhando em vários hospitais pra ter um melhor sustento (P11).

Espero melhorias. Por mais que enfermagem seja legal, tem um déficit muito grande. Eu digo pela minha cidade. Suzano não é uma cidade tão pequena, mas também não é tão grande. Só que o nível da saúde lá é péssimo. Tantos para os profissionais como para os pacientes (P12).

Espero que a enfermagem seja mais reconhecida, pois é muito desvalorizada (P13).

\section{b) Compromisso, interação e o cuidado}

Queria que crescesse mais no sentido de tratar as pessoas. Ainda tem aquela coisa de, como vou dizer, descontar... assim, de fato que eles deixassem o problema pra fora. (...).Porque é fácil cuidar de uma pessoa cheirosa, que toma banho, fazer o exame físico, e pegar uma pessoa que tá lá no meio da rua todo vomitado, evacuado, sujo, cheio de piolho, cheio de ferida. (...). Acho que o enfermeiro ou o técnico ou o auxiliar, tem que aprender a ser humano mesmo. Acho que só devia dar o COREN, tipo como carta de motorista, aquela coisa bem provisória pra ver se a pessoa está realmente apta para aquilo, porque ser feito nas coxas não dá (P2).

Acho que devia melhorar a o atendimento ao paciente (P6).

Espero que a área da saúde no geral melhore. Tanta gente se formando como enfermeiro que dá até medo. Vai saber se daqui a 10 anos terá espaço para todas as pessoas que estão se formando agora? Desse modo, cai a qualidade na assistência do cuidado (P15).

c) Estar estável financeiramente

Espero ser enfermeira e ficar bem profissionalmente e financeiramente (P1).

Se eu falar que não penso financeiramente, eu seria hipócrita. Penso em ter uma vida estabilizada (P8).

\section{d) Realização de um sonho no presente momento projetado ao futuro}

Vejo-me daqui $7 / 8$ anos, quem sabe, formada. Com pós em ortopedia. Pretendo me alistar na Marinha ou na Aeronáutica. É um sonho. São dois sonhos que eu posso ligar, que é me alistar, e me tornar enfermeira (P3).

Quero fazer pós em obstétrica porque eu gosto muito da vida (P5). 
Pretendo conhecer mais detalhes sobre a área e mais pra frente não quero ficar parada na enfermagem, quero estudar medicina (P9).

e) Trabalhar em uma área específica da Enfermagem relacionada às necessidades pessoais vivenciadas no momento presente

Quero cuidar de pessoas portadoras do vírus do HIV. Não quero trabalhar em hospital. Quero ter minha ONG. Tive oportunidade de trabalhar em uma ONG e ter uma parceria. Quero ajudar principalmente as pessoas portadoras do HIV e também o pais, amigos (P4).

f) Mudança no comportamento

Queria que mudasse um pouco essa rivalidade. Já começa pelo jaleco azul. Essa necessidade de colocar o jaleco azul no trem, no ônibus, no metro, pra poder diferenciar do técnico (P7).

Daqui a alguns anos, espero que a enfermagem seja mais unida. Você percebe um grupo de pessoas muito desunidas (P14).

A categorização dos discursos elencou elementos imprescindíveis para discutir a Identidade da profissional da Enfermagem sob a ótica dos participantes, que serão apresentadas no capítulo a seguir. 
6 DISCUSSÃO 


\section{DISCUSSÃO}

\subsection{CONFIGURAÇÕES IDENTITÁRIAS DO ENFERMEIRO}

Os discursos dos participantes da pesquisa na categoria 1 - Ampliando a compreensão do ser enfermeiro, revelaram uma identidade para si destacando que o enfermeiro é um profissional importante, que cuida, zela e salva vidas. Nesse sentido, Paterson e Zderad (1979) apud Castanha e Zagonel (2005, p. 557) retratam a teoria humanista, cujo enfoque se pauta no cuidado praticado pelo enfermeiro. Existe um vínculo que transcende a relação sujeito-objeto. Há "uma relação intersubjetiva, baseada na consciência existencial que ele tem de si e do outro".

Observa-se forte conotação ideológica no discurso do P1 quando diz que ser enfermeiro é "honrar aquilo que você faz à pátria". Nesse sentido, Parsons (1997, p. 18) relata que "as interessadas no curso de enfermagem veem a profissão não somente como meio de vida, mas, por motivos e ideais mais elevados de se prepararem para um grande serviço patriótico e humanitário".

Comparativamente à questão da identidade para si, no contexto da Segunda Guerra Mundial, foram enviadas 73 enfermeiras para a Itália em 1944, junto à Força Expedicionária Brasileira (FEB) - órgão criado pelo presidente Getúlio Vargas - e à Força Aérea Brasileira (FAB), para cuidar dos soldados. Vislumbra-se que à época a figura da enfermeira simbolizava a Pátria-Mãe, ou seja, aquela que estendia os cuidados maternos aos soldados no front de guerra (Cytrynowicz, 2000).

$\mathrm{Na}$ subcategoria ser enfermeiro é doação e dedicação, os discursos dos participantes P9 e P10 denotam que o legado da Enfermagem está embasado na origem ideológica da Enfermagem brasileira, que segundo Rodrigues (2001), era permeada de uma atuação caritativa.

Para Ribeiro et al. (2006), o espírito de doação, do cuidar e do servir advém das relações sociais e familiares, desde a infância. Assim, a essência da enfermeira está pautada na doação por natureza. Essa conotação caritativa da profissão advém da Enfermagem pré-profissional, como uma prática social pautada na bondade e no altruísmo, sobretudo na caridade (Silva, 1986). 
No quesito dedicação, Roscani e Guirardello (2010) relatam que a profissão de Enfermagem lida com situações críticas na vida de uma pessoa e exige alta concentração para trabalhar com as tarefas complexas. Além do conhecimento técnico-científico, o enfermeiro necessita possuir habilidade de comunicação e relacionamento.

O discurso do P8 retrata o enfermeiro como um profissional que cuida de forma holística. Nessa perspectiva, Salomé, Martins e Espósito (2009) apontam que o cuidado ao ser humano é caraterizado nas práticas dos profissionais de enfermagem e circunda o cuidado integral do indivíduo no que tange à promoção, prevenção e tratamento da saúde, pensando no indivíduo como um todo, ou seja, da construção biológica e mental do ser.

Neto e Nóbrega (1999) relatam que o termo holismo tem sobressaído nas duas últimas décadas na área da Enfermagem e tem servido como âncora para definições da saúde.

Tendo em vista que o advir do terceiro milênio substancia o despertar do pensamento humano para um novo paradigma, a visão holística surge, nesta virada de século, como um holograma que considera o todo e as partes em que o programa do todo se reflete (Neto e Nóbrega, 1999, p. 233).

Referente ao discurso do colaborador P11, na subcategoria é o profissional que tem grande responsabilidade, reflete que a profissão do enfermeiro, bem como suas atribuições, requerem um agir comprometido com ética profissional.

É considerável ressaltar que esse participante já é formado como auxiliar de Enfermagem e possui cursos em outras áreas que abrangem a saúde. Esse discurso permite a aproximação dos ensinamentos de Dubar (2005), mormente quando esse autor discute que a identidade de um profissional está interligada ao processo de socialização e interação entre os indivíduos. Essa interação pode estar associada ao ambiente familiar, escolar, do trabalho, entre outros. Assim, o fato do participante já ter tido contato com a área da saúde, permitiu que ele observasse o ambiente de trabalho do enfermeiro, formando para si, uma definição das atividades deste profissional.

Para Alves et al. (2007, p. 279) "a dimensão profissional das identidades adquire importância particular a partir da compreensão de cada possível configuração identitária". Esse processo aflora da transição da socialização 
profissional e das identidades sociais, isto é, da conexação indissociável da identidade para si, formada e consolidada no decorrer da vida e da identidade para o outro, ou seja, aquilo que o outro diz em relação ao que eu sou.

O fragmento do discurso do colaborador P7 difere do contexto da essência do trabalho do enfermeiro, tão difundido pelo cuidado, responsabilização e doação, como se vê refletido na subcategoria sobre o ser profissional que tem detém o poder. Esse olhar pode estar associado à divisão técnica do trabalho de Enfermagem, a qual teve origem no século XIX, à época da criação da Enfermagem moderna ou profissional ${ }^{8}$. Ainda nessa perspectiva, Gastaldo e Meyer (1989) destacam que a divisão social e técnica do trabalho de enfermagem ocorreu por conta do cuidado direto ao doente não ser considerado apropriado para mulheres de classe social elevada. Portanto, as categorias de "nurses" e "ladies nurses" foram criadas para dizer quem eram e de onde provinham socialmente. As "nurses" eram treinadas para realizarem o trabalho manual junto ao paciente e as "ladies nurses" estavam voltadas ao trabalho intelectual, administrativo e supervisão do ensino (Oguisso, 2014; Silva, 1986).

Dubar (2012, p. 358) destaca que no sistema produtivo existem os trabalhos considerados como "serviços sujos" e "as funções de elite". Os primeiros são desvalorizados e os segundos são tidos como atribuições "mais nobres" e executadas por pessoas mais qualificadas.

Desse modo, o discurso produzido por esse colaborador P7 traz essa diferenciação do trabalho do enfermeiro com o trabalho do auxiliar de enfermagem. Esse trabalho "sujo" se reflete ao mencionar que o enfermeiro passa a "tratar o auxiliar e o técnico um pouco meio que, como se fosse o faxineiro dele" (P7), essa frase traduz aquilo que o autor relata como atividades excluídas do sistema, ou seja, relacionada às "pessoas que fazem trabalhos pesados". Assim, Hughes (1996) afirma que quando um indivíduo chega ao chamado "status da profissão", ou seja, em seu total prestígio, esse profissional passa a incumbir "tarefas sujas" a outros, neste caso ao auxiliar e ao técnico de Enfermagem.

Em todo ofício, preferem-se certas tarefas a outras, algumas são zelosamente defendidas, enquanto outras são delegadas de bom grado aos que são vistos como inferiores, por exemplo, as mulheres e os negros, quer

\footnotetext{
${ }^{8}$ Florence Nightingale é considerada a fundadora da Enfermagem Moderna, tendo visibilidade por suas competências assistenciais e gerenciais. Em 1854, participou da Guerra da Crimeia como enfermeira voluntária (Padilha, 1998).
} 
se encontrem no interior ou no exterior do ofício e da profissão. Os imprevistos que todas as pessoas enfrentam ao longo de sua carreira profissional constituem um tema sempre recorrente (Hughes,1996 apud Dubar, 2012, p. 357).

O poder é conferido como um fenômeno interacionista, que flui continuamente em todas as fases de vida e em todos os espaços da vida social no dia a dia. "Pelo seu entendimento de poder que possibilitou e possibilita uma maior compreensão das relações e dos diferentes jogos e lutas nos quais estamos, continuamente, imersos" (Costa et al., 2008, p. 633).

Ainda no tocante à identidade para si, há processos que permitem que seja consolidada uma identidade, no que tange à trajetória social e experiências de vida, ou seja, aquilo que o indivíduo vivencia e o que ele conta sobre si mesmo (Dubar, 2005).

Quanto à categoria 2 - Enfrentando os desafios da escolha profissional, observa-se que a mesma constitui-se como um fator importante, servindo como subsídio para investigação de indícios relacionados à identidade profissional do enfermeiro sob a ótica do outro, mas nos discursos dos participantes.

Cabe pontuar que as falas dos entrevistados que disseram não ter tido problema quanto à escolha profissional da Enfermagem, não evidenciaram uma caracterização concreta da identidade para o outro, apenas um discurso salientou que a escolha profissional foi bem aceita pelos familiares e entes queridos. Isso pode ser ratificado na subcategoria enfermeiro como missionário do cuidado (P5), no qual evidencia assertividade pela escolha da profissão elegida pelo participante.

É concernente remontar a escolha pela Enfermagem por Florence em razão do Chamado de Deus, aonde ela relata que sua missão era ser enfermeira por designação divina. Esse Chamado de Deus conceituado por Florence foi traduzido por ela mesma como vocação. Essa ideologia fora transferida para as enfermeiras inglesas, americanas, canadenses e, posteriormente, trazida para a América Latina. (Gomes et al., 2007). Essa inculcação ideológica permeia nos dias atuais, como se pode observar no discurso relacionado à identidade do enfermeiro como um missionário do cuidado.

Um dos participantes relatou que uma das motivações referida por sua mãe, foi a empregabilidade, criando-se assim, uma subcategoria. A mãe desse 
colaborador (P14) trabalha como técnica de Enfermagem. Sendo assim, ela possui vivência na profissão e por trabalhar junto aos enfermeiros pôde identificar para si que a área da Enfermagem dispõe de um leque com variados caminhos a seguir.

Vale destacar que o enfermeiro pode trabalhar em diversos campos de prática. Nesse sentido, a Resolução no 389, de 18 de outubro de 2011, retrata essa diversidade de atuação profissional, mostrando os registros de títulos de pósgraduação lato e stricto sensu concedido a enfermeiros. Na gama de especialidades encontradas, encontram-se elencadas as seguintes áreas: Enfermagem Aeroespacial; Auditoria e Pesquisa; Cardiologia (Perfusionista; Hemodinâmica); Centro Cirúrgico (Central de Material e Esterilização; Recuperação pós anestésica); Dermatologia (Estomaterapia; Feridas; Ostomias); Diagnóstico por Imagens; Doenças infecciosas e parasitarias; Educação em Enfermagem (Metodologia do Ensino Superior; Pesquisa; Docência no Ensino Superior; Projetos Assistenciais de Enfermagem; Docência para Educação Profissional); Endocrinologia; Farmacologia; Gerenciamento/Gestão (Gestão da Saúde; Gestão de Enfermagem; Gestão em Homecare; Administração Hospitalar; Gestão de Programa de Saúde da Família; Gestão Empresarial; Gerenciamento de Serviços de Saúde; Gestão da Qualidade em Saúde); Enfermagem em Hanseníase; Hematologia e Hemoterapia; Infecção Hospitalar; Enfermagem em Informática em Saúde; Enfermagem em Legislação (Ética e Bioética; Enfermagem Forense); Nefrologia; Neurologia; Nutrição Parenteral e Enteral; Oftalmologia; Oncologia; Otorrinolaringologia; Pneumologia Sanitária; Enfermagem em Políticas Públicas; Enfermagem em Saúde Complementar; Saúde da Criança e do Adolescente (Neonatologia; Pediatria; Hebiatria; Saúde Escolar; Banco de Leite Humano); Saúde da Família; Saúde da Mulher (Ginecologia; Obstetrícia); Saúde do Adulto (Enfermagem em Saúde do Homem; Enfermagem em Saúde do Idoso; Gerontologia; Enfermagem em Saúde Mental); Saúde Pública (Saúde Ambiental); Saúde do Trabalhador; Saúde Indígena; Sexologia Humana; Terapias Holísticas Complementares; Terapia Intensiva; Transplantes; TraumatoOrtopedia; Urgência e Emergência (Atendimento Pré-hospitalar; Suporte Básico de Vida; Suporte Avançado de Vida); Enfermagem em Vigilância (Sanitária; Epidemiológica) e Enfermagem offshore e aquaviária (Cofen, 2011).

Diferentemente, as subcategorias seguintes divergem, pois os discursos se relacionam à recusa ou não aceitação da escolha profissional do enfermeiro pelo grupo social dos colaboradores. Surgindo assim, vestígios de uma identidade para o 
enfermeiro como um profissional que trabalha excessivamente, sendo isso discutido nas falas dos participantes P1 e P3.

Freitas, Fugulin e Fernandes (2006, p. 435) mencionam o fato da profissão de Enfermagem estar inserida em um contexto de cuidado ininterrupto, logo requer uma assistência em período integral, incluindo-se turnos ininterruptos de revezamento, plantões de final de semana, noturnos e feriados.

Em uma reportagem em janeiro de 2015 no site da Câmara dos Deputados, demonstrou que há uma proposta para votação em fixar em 30 horas a carga de trabalho semanal de enfermeiros, técnicos e auxiliares de Enfermagem e parteiras. Algumas instituições públicas já adotam as 30 horas de trabalho, porém, no setor privado, a jornada de trabalho da enfermagem é de 44 horas semanais (Brasil, 2000).

Outro ponto que marca a fala nos discursos é que as enfermeiras são vistas de maneira estereotipada na subcategoria enfermeira como representante da mulher de vida fácil (P2).

A historiografia pode explicar o motivo dessa imagem trivial da enfermeira ter sido concebida, quando Santos e Luchesi (2002) relatam que "os estereótipos hoje relatados, na sua maioria se referem a um passado remoto que foi superado pela cientificidade", pois antigamente essa profissão era exercida pelas mulheres e era eminentemente manual. Lembrando que antigamente ser mulher era sinônimo de cuidado ao lar, esta estava voltada para atividades domésticas e que esse consenso se perpetuava pelas próprias mulheres e suas famílias. A mulher já sofria preconceito e se caracterizava como um ser inferior. O trabalho exercido pelas mulheres era socialmente desvalorizado.

Vale ressaltar que na obra póstuma de Tito Lívio Castro, a mulher foi analisada sob o ponto de vista biológico baseado no tamanho e peso do crânio. Foi enfatizado, nessa obra prefaciada por Sílvio Romero ${ }^{9}$, que o cérebro de uma mulher pesava menos do que de um homem, portanto, isso determinava mais um fator de inferioridade e insipiência da mulher. Entretanto, Castro (1983) tinha preocupação em estudar esse aspecto craneológico para facilitar e favorecer a inserção das mulheres na educação, pois acreditava que somente dessa forma a mulher poderia evoluir e perpetuar o conhecimento às futuras gerações.

\footnotetext{
${ }^{9}$ Castro estudou no Imperial Colégio Pedro II e Sílvio Romero foi seu professor. Romero prefaciou dois livros póstumos de Castro (Almeida, 2007).
} 
Desse modo, há uma dicotomia na imagem da enfermeira que corresponde à santa/prostituta, isso persiste até hoje no imaginário social. A representação santa provém da época que o cuidado era realizado pelas religiosas, diaconisas, cuja ação e enfoque eram a caridade e filantropia; ou prostituta que representa o trabalho realizado por mulheres de moral duvidosa e que aceitava propina ou como se mostra hoje na vestimenta de fantasia com a enfermeira em traje de liga preta e sutiã de taça (Baptista, Barreira, 1997).

É importante relatar o que Dubar (2005) diz acerca da identidade para o outro, no sentido de que o indivíduo pode ser identificado por outrem através da definição imposta dos papéis (homem/mulher) ou distinguida numericamente (estado civil, números, entre outros) ou de identificações por classes ou grupos. Neste caso, presume-se que a identificação da enfermeira nesta subcategoria (enfermeira como representante da mulher de vida fácil) está intricada a uma identidade para o outro em uma representação de classe ou por conta do gênero feminino.

A subcategoria profissional não reconhecido (P8, P9) demonstra que a profissão de Enfermagem é invisível à sociedade. De acordo com Kemmer e Silva (2007b), é visível apenas como um agente subordinado ao médico e que é mal remunerado.

Erdmann et al. (2009, p. 638) relata que:

O status profissional constrói-se a partir das atitudes individuais que formam o coletivo e que, por sua vez, se refletem na ampliação das intervenções sociais, mais expressivamente, na ocupação de espaços que deem margem e reconhecimento à enfermagem como protagonista de um novo saber e fazer.

Ainda no tocante à identidade para o outro emergiu a subcategoria profissional mal remunerado $(\mathrm{P} 7)$.

Segundo Lima et al. (2009) a satisfação no trabalho está interligada ao fator salário, não como um aspecto isolado, mas caracterizada como um incentivo ao trabalho do indivíduo, e para que os enfermeiros alcancem uma renda adequada, precisam trabalhar em mais de um emprego, adquirindo nesse processo estresse e desestimulando-o a permanecer na área.

Dubar (2005) relata que o que o outro determina como identidade pode não estar relacionada com que o indivíduo pensa de si. Pode-se ratificar essa teoria ao fazer uma comparação com os discursos dos participantes na identidade para si e 
na identidade para o outro, principalmente quando a identidade para o outro está atrelada ao papel do profissional enfermeiro de forma negativa. Mesmo que essa visão do outro em relação ao enfermeiro seja diferenciada da qual o participante tem para si, ele (participante) firma sua definição de uma identidade do enfermeiro positiva, portanto "a identidade nunca é dada, ela sempre é construída e deverá ser (re)construída em uma incerteza maior ou menor e mais ou menos duradoura" (Dubar, 2005, p. 135).

No tocante à categoria 3 - Construindo o processo de socialização no contexto da escolha profissional, observa-se que as influências que apoiaram a decisão da escolha pela graduação em Enfermagem. Nesse sentido, a escolha de uma profissão reincide na decisão de seguir uma carreira ao longo da vida. Ademais, a escolha profissional se manifesta por um conjunto de ideais e sentimentos individuais e coletivos, bem como o desejo de projetar-se, configurando-se como uma necessidade. Desse modo, com o amadurecimento e desenvolvimento da personalidade e da identidade pessoal do indivíduo, faz-se a escolha por uma carreira (Rodrigues, Bormio, 2008).

Os discursos produzidos pelos participantes nesse item concentraram-se na afinidade pela área da saúde, seja na infância, adolescência ou na trajetória de vida com experiências pessoais/sociais, ou mesmo por influências dos entes queridos (família, amigos, vizinhos) inseridos na área que representaram a profissão.

Desse modo, desvencilharam-se os motivos nos quais os levaram a escolher a faculdade de Enfermagem. Houve diversas motivações que firmaram ou emergiram a necessidade da escolha pela Enfermagem.

A primeira subcategoria que surgiu foi a experiência de ter vivenciado uma situação de necessidade de saúde na família, a qual evidenciou que a escolha pela profissão é determinada pelas vivências e experiências de vida. É importante destacar que essa subcategoria foi relatada em maior escala, pois esteve presente na maioria dos discursos dos colaboradores.

Percheron (1974, apud Dubar, 1997) relata que o enfoque de suas observações se deu nas abordagens dos fenômenos da socialização:

Qualquer socialização é o resultado de dois processos diferentes: processo de assimilação e de acomodação. Pela assimilação, o sujeito procuraria modificar o seu ambiente para o tornar mais conforme aos seus desejos e diminuir os seus sentimentos de ansiedade e de intensidade; pelo contrário, pela acomodação, o sujeito teria tendência a modificar-se para responder às 
pressões e aos constrangimentos do ambiente (Percheron, 1974, p. 25 apud Dubar, 1997, p. 17).

Desse modo, o fato de experimentar momentos e situações em um ambiente sociável, colabora para desenhar uma necessidade pessoal e desenvolver uma atitude projetada para determinar a carreira que se pretende seguir.

D'Antonio (2010) retrata que muitos estudos têm sido difundidos abordando as razões que contribuem para a escolha profissional da Enfermagem. Uma dessas razões ocorre pelo fato dos indivíduos trazerem consigo diversas experiências e que processam sua história de vida apoderando-se das possibilidades de escolha para obter êxito nos problemas concernetes à própria escolha ou ao ambiente a qual se encontra.

Assim como a vivência de ter cuidado de outrem, a categoria já ser profissional da área da Enfermagem atuante ou não contribuiu para que os graduandos definissem sua escolha profissional pela Enfermagem, independente se ele seja um profissional da área da saúde, especificamente auxiliar ou técnico de Enfermagem, que esteja atuando ou não.

Nessa subcategoria o participante P1 e P2 se repetem, pois já estão inseridos na subcategoria anterior. Desse modo, pode-se aduzir que a escolha da profissão atrelada ao processo de socialização não se restringe a um fator isolado ou a um único acontecimento, pois além desses participantes terem se motivado a escolher pela graduação de Enfermagem por causa da experiência de ter cuidado de alguém, a escolha foi reafirmada e consolidada pelo fato de já ter tido contato com a área da Enfermagem.

Kemmer e Silva (2007a) relatam que existem influências que auxiliam na escolha profissional, pelo fato da profissão ser socialmente caracterizada e representada. A imagem do profissional, neste caso, do enfermeiro, vai se desenvolvendo a partir do relacionamento que o indivíduo possui em relação à área. Nesta perspectiva, exemplificada pela ação destes participantes no sentido de já terem tido um contato prévio com a Enfermagem, ocorre uma conexão com aquilo que vê com aquilo que se pretende ser, imbricado com a circunstância real vivida.

Nesses discursos apontados, é possível deduzir que realizado o curso de auxiliar ou técnico de Enfermagem, bem como exercido esta função, permitiu de alguma forma que os participantes assimilassem e agregassem habilidades, atitudes, valores, conhecimentos, visualizassem padrões de comportamento, 
tradições e sentimentos. Esse conjunto de competências favoreceu a escolha pela graduação em Enfermagem.

A subcategoria ter tido contato com profissionais de Enfermagem, corresponde ao discurso dos participantes P4, 5 e 6. Esta menção correlaciona com a subcategoria supracitada, embora os entrevistados não tenham cursado o auxiliar ou técnico de Enfermagem e nem trabalhado nas áreas afins. No entanto, puderam ter um primeiro contato com a área da Enfermagem, seja por meio do auxílio nos trabalhos relacionados ao curso de Enfermagem (técnico ou superior), como relatado pelos participantes $\mathrm{P} 4$ e 5 , ou seja pelo fato de ter alguém próximo que já trabalhe na área, como relatado pelo participante P6.

Para Spindola e Moreira (1999), a escolha pela Enfermagem pode ser motivada pelo fato dos parentes e/ou entes queridos estarem inseridos já na área, servindo como figura representativa da profissão e de exemplos efetuados acerca do exercício específico de suas atribuições.

Dubar (2005) pontua que a profissão é incorporada na singularidade do indivíduo, principalmente no que tange à mudança ao longo do tempo das condições de trabalho e da tecnologia.

Referente à categoria 4 - Projetando o futuro profissional, a subcategoria que mais se destacou foi aceitação, respeito, valorização, reconhecimento da profissão do enfermeiro. Esses elementos acompanham a necessidade de qualquer profissão em ser identificada e caracterizada assertivamente.

Pai, Schrank e Pedro (2006) mencionam que o modelo em saúde inserido na modernidade ainda está pautado na doença. Mesmo com toda a movimentação para trazer um novo conceito sobre a saúde, pela carta de Otawa ${ }^{10}$, onde transcende apenas o tratar do corpo físico e passa a envolver aspectos psicológicos, ambientais, políticos e econômicos, a atuação dos profissionais de saúde estão voltados em prol da queixa-conduta. Nessa circunstância, o trabalho médico se sobressai por atrelar-se veemente à doença e o trabalho da Enfermagem se situa como complementação e não como chave principal no processo, portanto, a Enfermagem passa a ser vista como uma profissão voltada para abnegação,

\footnotetext{
10 "A Carta de Ottawa de 1986 reafirma a importância da promoção à saúde e aponta, principalmente, a influência dos aspectos sociais sobre a saúde dos indivíduos e da população" (Heidmann, 2006, p. 353).
} 
caridade, sustentando assim, o mito da doação, levando à invisibilidade como profissão que possui deveres e direitos.

Dubar (2005) pontua que o termo profissão possui dois sentidos, sendo o primeiro definido como emprego, que em inglês é determinado occupations; o segundo definido como profissão liberal ou científica, em inglês compreendido como professions, que corresponde aos clérigos, médicos e advogados.

Antigamente o termo profissão estava associado às corporações de ofícios interligados principalmente às comunidades familiares, onde as habilidades relacionavam-se às artes, exercendo um monopólio deste ofício. Os grupos organizados advogavam seus espaços e lutavam para manterem seus privilégios. Esses ofícios se definiam em trabalhadores braçais, intelectuais, artistas e artesões, nos quais havia um juramento para atender aos requisitos, compromissos e regras desses grupos, cujo representante era reconhecido pelo Poder Real (Dubar, 2005).

Esses ofícios/grupos ligados às artes liberais e mecânicas só foram desagregados com o advento das Universidades e foi definido que as artes liberais se ligariam às atividades do espírito, determinadas como profissões e as artes mecânicas foram identificadas como ofícios (Dubar, 2005).

Revisitando a trajetória da profissionalização da Enfermagem é importante ratificar que ela foi considerada como profissão em 1890 quando foi fundada a Escola Profissional de Enfermeiros e Enfermeiras, no Hospício de Alienados, atualmente chamada de Escola de Enfermagem Alfredo Pinto, da Universidade Federal do Estado do Rio de Janeiro (Unirio) (Oguisso, Campos, Moreira, 2011).

As investigações evidenciam que a visibilidade do enfermeiro implica na articulação de competências com evidências a nível técnico, científico e relacional, o que concorre para a representação social da profissão (Erdmann et al., 2009, p.638).

Quanto à subcategoria compromisso, interação e o cuidado, os discursos remetem mudanças no paradigma do cuidado e das ações da Enfermagem. Desse modo, cabe pontuar a necessidade de humanizar. Esse conceito é explicado por Corbani, Brêtas e Matheus (2009, p. 352):

Que é humanizar, senão a prática do humano - do ser? Assim, quando ouvida a intuição, como humanos que somos, é manifestado que o que realizamos é humano - isso é, espontaneamente, humanizar. Entendemos que humanização é usar da nossa humanidade para cuidar da humanidade do outro. Depreendemos em algumas narrativas como "É um ser humano que está ali, não é uma máquina. Você belisca, ele faz ai."que o 
profissional da enfermagem se vê utilizando de mecanismos automáticos em semelhança de robô - transparecendo se esquecer de sua natureza. Ele executa ordens, muitas vezes sem refletir sobre o significado atribuído a elas, e cuida do outro de igual modo. Quando nos damos conta de que a humanidade é nossa e deve ser vivida plenamente, não corremos o risco de nos desviar desse curso natural.

Alguns entrevistados definiram o futuro da profissão da Enfermagem com uma visão panorâmica geral, atentando para as necessidades da categoria. Outros entrevistados trouxeram uma contribuição particular, projetando-se como ator principal no processo da profissionalização. Pode-se inferir essa singularidade nas subcategorias: estar estável financeiramente; realização de um sonho no presente momento projetado ao futuro e trabalhar em uma área específica da Enfermagem relacionada às necessidades pessoais vivenciadas no momento presente.

Bohoslavsky (1998) aponta que existem poucos estudos direcionados à relação do homem com seu futuro. Para tanto, enaltecem a importância da Psicologia de Orientação Profissional ao se referir ao futuro do indivíduo em sua profissão escolhida.

A projeção de vida para o futuro pode contribuir para levantar as premências da própria profissão, permitindo reconfigurar os modelos educacionais, tanto no ensino fundamental, quanto no ensino médio, e, principalmente, no ensino superior.

Para Coutinho, Krawulski e Soares (2007), atualmente, ocorrem modificações constantes, acarretando em reconfigurações de identificação, pois existe uma integração no mundo laboral com o passado (o que foi vivido), com o presente (o que executa), com o futuro (o que se pretende).

Dubar (2005, p. 97) relata que há características pontuais nos indivíduos que constitui em:

\begin{abstract}
Uma incorporação dos modos de ser (de sentir, de pensar e de agir) de um grupo, da sua visão do mundo e da sua relação com o futuro, das suas posturas corporais, assim como das suas crenças intimas. Quer se trate do grupo de origem no seio do qual se desenrolou a primeira infância e ao qual pertence "objectivamente" ou de um grupo exterior no qual quer integrar-se e ao qual se refere "subjectivamente", o indivíduo socializa-se, interiorizando valores, normas, disposições que o tornam um ser socialmente identificável.
\end{abstract}

A subcategoria mudança no comportamento incide na questão da transmutação das relações entre enfermeiros e auxiliares/técnicos de Enfermagem, 
haja vista que estes profissionais estão envolvidos com objetivos em comum (saúde e cuidado), porém, possuem diferenças quanto às atribuições.

Essa diferença de atribuições é apresentada na Lei no 7.498 de 1986, regulamentada pelo Decreto de no 94.406 de 1987 e relata que o enfermeiro deve possuir diploma com curso superior, o técnico de Enfermagem deve ser diplomado ou certificado de técnico de Enfermagem, expedido de acordo com a legislação e registrado no órgão competente e o auxiliar de Enfermagem deve ser diplomado por instituição de ensino, nos termos da Lei e registrado no órgão competente (Brasil, 1986).

Hughes (1958, apud Dubar, 2012) acredita que existe uma divisão moral do trabalho. Nesta divisão há uma segregação entre as profissões, onde uma pode ser mais valorizada simbolicamente pela sociedade. Desse modo, entre as categorias da profissão de Enfermagem (auxiliar de Enfermagem, técnico de Enfermagem e enfermeiro), a divisão do trabalho existe dentro da própria equipe de trabalho, o que é enfatizado pelo dispositivo da lei que regula o exercício da profissão, denotandose, inclusive, uma relação de subalternidade das categorias a nível médio (auxiliar e técnico) em relação ao profissional graduado (enfermeiro).

A subcategoria mudança no comportamento reflete sobre a desunião existente na equipe de enfermagem, segundo o depoimento dos participantes P7 e P14.

Esse discurso pronunciado retrata as experiências passadas que foram consideradas de vital importância para mudanças na realidade presente e futura.

Esse conjunto de história e expectativas futuras é retrato por Dubar (2005, p. 19):

Essas autodefinições de atores, em um contexto dado, não são estritamente
determinadas pelo próprio contexto. Cada um dos atores tem uma história,
um passado que também pesa em suas identidades de ator. Não se define
somente em função de seus parceiros atuais, de suas interações face a
face, em um campo determinado de práticas, mas também em função de
sua trajetória, tanto pessoal como social. Essa "trajetória subjetiva" resulta a
um só tempo de uma leitura interpretativa do passado e de uma projeção
antecipatória do futuro. As identidades de ator estão assim vinculadas a
formas de identificação pessoal, socialmente identificáveis. Elas podem
assumir formas diversas, assim como são diversas as maneiras de exprimir
o sentido de uma trajetória, ao mesmo tempo sua direção e sua
significação.

Frente a isso, é de vital importância atentar para os estudos que refletem as 
identidades pessoais e profissionais para compreensão da profissão em suas variadas facetas e revelar as lutas, dificuldades e vitórias, não somente para o grupo de profissionais da Enfermagem, mas sim, para os que a escolhem como profissão e, também, para a sociedade que em algum momento terá necessidade de ser cuidado por um profissional da Enfermagem. 
7 CONCLUSÃO 


\section{CONCLUSÃO}

As questões relativas à identidade do enfermeiro foi objeto de estudo nessa pesquisa, haja vista que existe a necessidade em aprofundar-se nesse tema, uma vez que a Enfermagem vem se destacando no mercado de trabalho e vem ganhando espaços que anteriormente não ocupavam e, assim, torna-se fundamental que essa profissão seja afirmada e reconhecida socialmente.

Contudo, esse reconhecimento social se desvela a partir do momento em que se investiga uma realidade que permitirá desvendar possíveis desdobramentos presentes e tecer um futuro.

Denota-se que a Enfermagem passou e passa continuamente por múltiplos processos na construção de uma identidade capaz de fazer compreender seu papel na sociedade. Portanto, foi imprescindível conhecer as percepções inerentes à identidade e as escolhas profissionais a partir das percepções de estudantes de Enfermagem ingressantes de uma Faculdade privada.

De acordo com os objetivos propostos para esse estudo, tornou-se possível revisitar fragmentos históricos importantes que retrataram pluralidades identitárias, revelando configurações diversificadas a respeito do que é ser enfermeiro. Esses aspectos são descortinados quando a História da Enfermagem é colocada em evidência.

Os achados da presente investigação possibilitaram o mapeamento do perfil sócio-demográfico da população estudada, demonstrando a estrutura e arranjo espacial do grupo estudado. Esse ponto constituiu-se em um elemento essencial para caracterizar a realidade do alunado a fim de compreender e relacionar seu perfil com sua natureza individual e coletiva.

Ao longo desse estudo, tornou-se possível discutir a temática proposta, sob a ótica do Sociólogo Claude Dubar, podendo assim, clarificar de forma analítica o ponto de vista desse autor de que a construção de uma identidade é um processo dinâmico e social em diferentes contextos.

Os discursos dos colaboradores participantes dessa pesquisa foram vitais para compreender a escolha pela profissão de Enfermagem a partir de uma dimensão individual e coletiva. Dessa forma, percebeu-se que mesmo sendo ingressantes e mesmo alguns já serem profissionais da área (auxiliares e/ou 
técnicos de Enfermagem) os aspectos relacionados à identidade profissional em certos momentos caracterizam "crises" quando os enunciados apresentaram ambiguidades relacionadas ao trabalho do enfermeiro e do reconhecimento de seu papel perante a sociedade, principalmente quando são expostas colocações que retratam uma Enfermagem ideal e uma Enfermagem real. Ou seja, a Enfermagem ideal apresentada nos discursos dos colaboradores se mostra assertivamente quando o colaborador apodera-se de uma identidade para si positivamente. Entretanto, a Enfermagem real é apresentada como uma profissão que precisa de ajustes e melhorias em todas as dimensões (assistencial, organizacional ou gerencial, profissional, incluindo-se a formação, dentre outras), sendo demonstrado, principalmente, nos discursos que revelam indícios de uma identidade do enfermeiro para o outro.

Como se pôde aduzir, os graduandos do primeiro e segundo semestres trazem consigo compreensões do que é ser enfermeiro a partir de suas vivências e experiências consubstanciadas com o que a sociedade pensa a respeito da figura do enfermeiro, embora, muitos deles tenham declarado que a escolha pela profissão foi conturbada por conta dos indivíduos que interagiram ou interagem ao longo de sua trajetória de vida. Entretanto, como exposto no decorrer da pesquisa, pode coexistir a identidade para si e a identidade de outrem desde que o indivíduo encontre um equilíbrio entre ambas as categorias.

Ao finalizar essa pesquisa, percebe-se que há necessidade de que outros trabalhos sejam realizados nessa mesma direção, pois ressurgem novas questões e outras preocupações e observações, permitindo assim, manifestar novos olhares e outras formas de reinterpretar os achados desse estudo e, consequentemente, gerar resultados diferenciados dos apresentados.

$\mathrm{Na}$ constante luta pelo reconhecimento e (re)construção de uma identidade profissional, o enfermeiro passa continuamente pela busca de uma imagem ideal que possa corresponder com seus anseios para conferir-lhe não somente direitos, mas autonomia e respeito. 
REFERÊNCIAS 


\section{REFERÊNCIAS}

Almeida AMA. Lívio de Castro e um outro olhar sobre a mulher no século XIX. Associação Nacional de História - ANPUH. In: Anais do 24ํㅗㅇㅡósio Nacional de História; 2007 Jul 15-20; São Leopoldo (RS) [internet]. São Leopoldo (RS): Unisinos; 2007. [citado 2015 ago 10]. Disponível em: http://anpuh.org/anais/wpcontent/uploads/mp/pdf/ANPUH.S24.0768.pdf

Almeida MP. Reformas neoliberais no Brasil: a privatização nos governos Fernando Collor e Fernando Henrique de Cardoso [tese]. Niterói, Universidade Federal Fluminense; 2010.

Alves CS, Cunha DO, Cunha VM, Gatti B, Lima LF, Hobold M et al. Identidade profissional de professores: um referencial para pesquisa. Educação e Linguagem, 2007 Jan-Jun; ano 10, 15: 269-83.

Barreira IA. Os primórdios da Enfermagem Moderna no Brasil. Esc. Anna Nery. Rev. Enferm; 1997; 1(N.esp):161-76.

Barros DLP. Teoria do discurso: fundamentos semióticos. $3^{\text {a }}$ ed. São Paulo: Humanitas; 2001.

Barros JA. História das ideias - em torno de um domínio historiográfico. Locus: revista de história, Juiz de Fora, 2007; 13(1): 199-209.

Barros JA. O campo da História. 8ª ed. Rio de Janeiro. Petrópolis: Vozes; 2011.

Baptista SS, Barreira IA. A luta da enfermagem por um espaço na universidade. Rio de Janeiro: Anna Nery/UFRJ; 1997.

Becerril LC; Gómez MAJ. Enseñanza y aprendizaje del pensamento reflexivo y crítico em estudiantes de enfermería em iberoamérica. Projeto multicêntrico desenvolvido pelas coordenadoras das Regiões de lberoamérica da Red Iberoamericana de Investigadores en Educación en Enfermería (RIIEE). México, 2012.

Bellaguarda MLR, Silveira LR, Mesquita MPL, Ramos FRS. Identidade da profissional enfermeira caracterizada numa revisão integrativa. Enfermagem em Foco $2011 ; 2(3): 180-183$.

Bloch M. Apologia da História ou o ofício do historiador. Rio de Janeiro: Zahar; 2001.

Boff J, Caregnato RCA. História oral de mulheres com filhos portadores de Síndrome de Down. Texto Contexto Enferm, Florianópolis, 2008 Jul-Set; 17(3): 57886.

Bohoslavsky R. Orientação vocacional: a estratégia clínica. $7^{a}$ ed. São Paulo: Martins Fontes; 1998 apud Ito LH, Soares DHP. Projeto do futuro e identidade: um estudo com estudantes formandos. Aletheia. Canoas 2008 Jun; (27): 65-80. 
Brasil. Conselho Nacional de Saúde (CNS). Resolução n 466/2012. Diário Oficial da União, Brasília, 13 jun. 2013. Seção 1:59.

Brasil. Decreto no 791, 27 de setembro de 1890. Cria no Hospício Nacional de Alienados uma escola profissional de enfermeiros e enfermeiras. In: Ministério da Saúde, Fundação Serviços de Saúde Pública. Enfermagem - legislação e assuntos correlatos. $3^{a}$ ed. Rio de Janeiro; 1974a.

Brasil. Decreto no 15.799, de 10 de novembro de 1922. Aprova o regulamento do Hospital Geral de Assistência do Departamento Nacional, de Saúde Publica. In: Brasil. Ministério da Saúde. Fundação Serviços de Saúde Pública. Enfermagem, legislação e assuntos correlatos. $3^{\text {a}}$ ed. Rio de Janeiro; 1974b.

Brasil. Lei no 4.024, de 20 de setembro de 1961. Fixa as Diretrizes e Bases da Educação Nacional. [internet]. Brasília; 1961 [citado 2014 Jul. 10]. Disponível em: http://presrepublica.jusbrasil.com.br/legislacao/108164/lei-de-diretrizes-e-base-de1961-lei-4024-61

Brasil. Lei no 7.498, de 25 de junho de 1986. Dispõe sobre a regulamentação do exercício da enfermagem e dá outras providências. Diário Oficial da União, Brasília, 26 jun. 1986. Seção 1:10.

Brasil. Lei no 9.394, de 20 de dezembro de 1996. Estabelece as diretrizes da educação nacional. [internet]. Brasília; 1996 [citado 2015 Set. 10]. Disponível em: http://www.planalto.gov.br/CCIVIL 03/leis/L9394.htm

Brasil. Ministério da saúde, justiça e negócios exteriores. Departamento Nacional de Saúde Pública. A enfermeira moderna; apelo às moças brasileiras. Rio de Janeiro: oficinas gráficas da inspetoria de demografia sanitária, Educação e Propaganda, 1922.

Brasil. Ministério da Educação e Cultura. Conselho Nacional de Educação. Parecer 314, de 06 de abril de 1994. Brasília (DF). Ministério da Educação e Cultura; 1994.

Brasil. Ministério da Educação. Conselho Nacional de Educação. Câmara de Educação Superior. Resolução n 3, de 7 de novembro de 2001. Institui as Diretrizes Curriculares Nacionais do Curso de Graduação em Enfermagem. Diário Oficial da União, Brasília, 9 nov. 2001. Seção 1:37.

Brasil. Ministério da Educação. Conselho Nacional de Educação. Resolução n 4, de abril de 2009. Dispõe sobre carga horária mínima e procedimentos relativos à integralização e duração dos cursos de graduação em Biomedicina, Ciências Biológicas, Educação Física, Enfermagem, Farmácia, Fisioterapia, Fonoaudiologia, Nutrição e Terapia Ocupacional, bacharelados, na modalidade presencial [internet]. [citado 2014 Ago. 15]. Disponível em: http://portal.mec.gov.br/dmdocuments/rces004 09.pdf

Brasil. Parecer no 163/72, C.C.R. de Currículos, de 28 de janeiro de 1972. Dispõe sobre o currículo mínimo dos cursos de enfermagem e obstetrícia. In: Brasil. 
Ministério da Saúde. Fundação Serviços de Saúde Pública. Enfermagem, legislação e assuntos correlatos. $3^{\underline{a}}$ ed. Rio de Janeiro; 1974c.

Brasil. Projeto de Lei - 2295/00. Câmara dos deputados. Redução da carga de trabalho de enfermeiros está pronta para votação, 30 de janeiro de 2015 [internet]. [citado 2015 Jun. 10]. Disponível http://www2.camara.leg.br/camaranoticias/noticias/TRABALHO-EPREVIDENCIA/481008-REDUCAO-DA-CARGA-DE-TRABALHO-DEENFERMEIROS-ESTA-PRONTA-PARA-VOTACAO.html

Brasil. Ministério da Educação. Exame Nacional de Desempenho dos Estudantes (ENADE). Relatório de Área 2013. Enfermagem. [citado 2015 Mar. 10]. Disponível em:

http://download.inep.gov.br/educacao superior/enade/relatorio sintese/2013/2013 r el enfermagem.pdf

Brito AMR, Brito MJM, Silva PAB. Perfil sociodemográfico de discentes de enfermagem de instituições de ensino superior de Belo Horizonte. Esc Anna Nery Rev Enferm 2009 abr-jun; 13 (2): 328-33.

Burke P. A Escola dos Annales, 1929-1989, a revolução Francesa da Historiografia. São Paulo: UNESP; 1989.

Campos PFS, Oguisso T. A Escola de Enfermagem da Universidade de São Paulo e a reconfiguração da identidade profissional da Enfermagem Brasileira. Rev. bras. enferm. [Internet]. 2008 Dez [citado 2015 Jul 14]; 61(6): 892-898. Disponível em: http://www.scielo.br/pdf/reben/v61n6/a17v61n6.pdf

Cardoso NCS, Matos MFS, Vieira MJ. A opção pela enfermagem: estudo retrospectivo em Sergipe. Rev. bras. enferm. [Internet]. 2003 Dez [citado 2015 Jul 14]; 56(6): 640-645. Disponível em: http://www.scielo.br/pdf/reben/v56n6/a10v56n6.pdf

Carvalho AC. Escola de Enfermagem da Universidade de São Paulo. Resumo Histórico: 1942-1980. São Paulo: Escola de Enfermagem da Universidade de São Paulo; 1980.

Cassab LA, Ruscheinsky A. Indivíduo e ambiente: a metodologia de pesquisa da história oral. Biblos, Rio Grande, 2004; 16(7): 24.

Castañeda LA. Eugenia e casamento. Hist. cienc. saude-Manguinhos. [internet]. $2003 \mathrm{Dez}$ [citado 2015 jul 14]; 10(3): 901-30. Disponível em: http://www.scielo.br/pdf/hcsm/v10n3/19305.pdf

Castro TL. A mulher e a sociogenia. Rio de Janeiro: Francisco Alves e Co., 1893.

Collet N, Schneider JF, Corrêa AK. A pesquisa em enfermagem: avanços e desafios. Rev. bras. enferm. [Internet]. 2000 Mar [citado 2015 Jul 14]; 53(1): 75-80. Disponível em: http://www.scielo.br/pdf/reben/v53n1/v53n1a09.pdf 
Conselho Federal de Enfermagem. Resolução COFEN - 389/2011. Atualiza, no âmbito do Sistema Cofen/Conselhos Regionais de Enfermagem, os procedimentos para registro de título de pós-graduação lato e stricto sensu concedido a Enfermeiros e lista as Especialidades Especialidades/residência de enfermagem áreas de abrangência [internet]. [citado 2015 mai 10]. Disponível em: http://www.cofen.gov.br/wp-content/uploads/2012/03/resolucao 389 2011.pdf

Conselho Federal de Enfermagem. Pesquisa inédita traça perfil da enfermagem. Diagnóstico da profissão aponta concentração regional, tendência à masculinização, situações de desgaste profissional e subsalário. [Internet]. 2015. [citado 2015 ago 14]. Disponível em: http://www.cofen.gov.br/pesquisa-inedita-traca-perfil-daenfermagem 31258.html

Corbani NMS, Brêtas ACP, Matheus MCC. Humanização do cuidado de enfermagem: o que é isso? Rev. bras. enferm. [Internet]. 2009 Jun [citado 2015 Ago 10]; 62(3): 349-54. Disponível em: http://www.scielo.br/pdf/reben/v62n3/03.pdf

Costa R, Souza SS, Ramos FRS, Padilha MI. Foucault e sua utilização como referencial na produção científica em enfermagem. Texto contexto - enferm. [Internet]. 2008 Dez [citado 2015 Mai 14]; 17(4): 629-37. Disponível em: http://www.scielo.br/pdf/tce/v17n4/02.pdf

Coutinho MC, Krawulski E, Soares DHP. Identidade e trabalho na contemporaneidade: repensando articulações possíveis. Psicol. Soc. [internet]. 2007; [citado 2015 ago 10], 19(N.esp): 29-37. Disponível em: http://www.scielo.br/pdf/psoc/v19nspe/v19nspea06.pdf

Cytrynowicz R. A serviço da pátria: a mobilização das enfermeiras no Brasil durante a Segunda Guerra Mundial. Hist. cienc. saude-Manguinhos [Internet]. 2000 [citado 2015 julho 17]; 7(1): 73-91. Disponível em: http://www.scielo.br/scielo.php?pid=S0104-59702000000200004\&script=sci arttext

D'Antonio P. American Nursing: a history of knowledge, authority, and the meaning of work. Baltimore: The Johns Hopkins University Press; 2010.

Dicionário da Língua Portuguesa. Miscigenação. Editor: Porto Editora, 2014.

Dourado LF. Reforma do estado e as políticas para a educação superior no Brasil nos anos 90. Educ. Soc., Campinas, 2002 Set; 23(80): 234-52.

Dubar C. A Socialização: construção das identidades sociais. Portugal: Porto; 1997.

Dubar C. Identidade profissional em tempos de bricolage: entrevista. Contemporaneidade e educação. Rio de Janeiro 2001, 6(9): 152-56.

Dubar C. A socialização: construção das identidades sociais e profissionais. São Paulo: Martins Fontes; 2005.

Dubar C. A crise das identidades: a interpretação de uma mutação. São Paulo: Universidade de São Paulo; 2009. 
Dubar C, Tripier P, Boussard V. Sociologie des professions. Paris: Armand Colin; 2011.

Dubar C. A construção de si pela atividade de trabalho: a socialização profissional. Cadernos de Pesquisa. 2012; 42(146), 351-67.

Erdmann AL, Fernandes JV, Melo C, Carvalho BR, Menezes Q, Freitas R et al . A visibilidade da profissão de enfermeiro: reconhecendo conquistas e lacunas. Rev. bras. enferm. [Internet]. 2009 Ago [citado 2015 Mai 21]; 62(4): 637-43. Disponível em: http://www.scielo.br/pdf/reben/v62n4/25.pdf

Espírito Santo TB. Enfermeiras francesas na capital do Brasil (1891 - 1895) [dissertação]. São Paulo, Escola de Enfermagem, Universidade de São Paulo; 2007.

Fávero MLA. A Universidade no Brasil: das origens à Reforma Universitária de 1968. Educar, Curitiba: UFPR; 2006, (28):17-36.

Fernandes JD. Uma década de diretrizes curriculares nacionais: avanços e desafios na enfermagem. In: Anais do $13^{\circ}$ Seminário Nacional de Diretrizes para a Educação em Enfermagem; 2012 Ago 30 - Set 1; Belém (PA) [internet]. Belém (PA): ABEn Universidade da Amazônia; 2012. [citado 2014 out 10]. Disponível em: http://www.abeneventos.com.br/13senaden/arquivo/CONFERENCIA-

ABERTURA 13-SENADEn.pdf

Fiorin JL. Elementos de análise do discurso. São Paulo: Contexto; 2002.

Fiorin JL. Linguagem e ideologia. 3.ed. São Paulo: Ática; 2005.

Fiorin JL. Linguagem e ideologia. 8ª̣ ed. São Paulo: Ática; 2007.

Fiorin JL. Elementos de análise do discurso. 15aㅗ ed. São Paulo: Contexto; 2014.

Fontella OM. Ocupações web: a construção de identidades profissionais em cenários recentes de trabalho [dissertação]. Porto Alegre, Universidade Federal do Rio Grande do Sul; 2002.

Freitas SM. História oral: possibilidade e procedimentos. São Paulo: Humanitas; 2002.

Freitas GF, Fugulin FMT, Fernandes MFP. A regulação das relações de trabalho e o gerenciamento de recursos humanos em enfermagem. Rev. esc. enferm. USP [Internet]. 2006 Set [citado 2015 Mai 14]; 40(3): 434-38. Disponível em: http://www.scielo.br/pdf/reeusp/v40n3/v40n3a16.pdf

Freitas GF, Fernandes MFP, Merighi MAB, Baptista PCP. Fenomenologia. In: Oguisso T, Campos PFS, Freitas GF. Pesquisa em História da Enfermagem. São Paulo: Manole; 2011. p. 372.

Fundação Oswaldo Cruz. Pesquisa retrata perfil de 1,6 milhão de profissionais de enfermagem no Brasil. [internet]. 2015. [acessado em 2015 Mai 4]. Disponível em: 
http://portal.fiocruz.br/pt-br/content/pesquisa-retrata-perfil-de-16-milhao-deprofissionais-de-enfermagem-no-brasil

Galleguillos TGB, Oliveira MAC. A gênese e o desenvolvimento histórico do ensino de enfermagem no Brasil. Rev.Esc.Enf. USP 2001 Mar; 35(1): 80-7.

Gastaldo DM, Meyer DE. A formação da enfermeira: ênfase na conduta em detrimento do conhecimento. Rev. Bras. Enferm., 1989. Jan-dez 42 (1/4): 7-13.

Goffman E. A representação do eu na vida cotidiana. Petropólis: vozes; 1985.

Goffman E. Estigma: notas sobre a manipulação da identidade deteriorada. 4. ed. Rio de Janeiro: LTC; 1988.

Gomes VLO, Backes VMS, Padilha MICS, Vaz MRC. Evolução do conhecimento científico na enfermagem: do cuidado popular à construção de teorias. Medellín. Invest. educ. enferm; 2007 Jul-Dez; 25(2).

Gonçalves MES. A invisibilidade da mulher negra na enfermagem profissional. Revista Eletrônica Multidisciplinar Pindorama do Instituto Federal de Educação, Ciência e Tecnologia da Bahia - IFBA. Junho 2012; 3(2).

Guimarães CM, Miranda TG. Enfermagem como prática social: determinantes socioistóricos e engajamento profissional. Estudos Goiânia 2002; 29(5):1207-35.

Heidmann ITSB, Almeida MCP, Boehs AE, Wosny AM, Monticelli M. Promoção à saúde: trajetória histórica de suas concepções. Texto Contexto Enferm, Florianópolis, 2006 Abr-Jun; 15(2):352-8.

Henriques HMG. Formação, sociedade e identidade profissional dos enfermeiros: a Escola de Enfermagem de Castelo Branco/Dr. Lopes Dias (1948-1988)b [tese]. Faculdade de Psicologia e de Ciências da Educação da Universidade de Coimbra; 2011.

Hughes EC. Men and their work. New York: Free Press of Glencoe; 1958 apud Dubar C. A construção de si pela atividade de trabalho: a socialização profissional. Cadernos de Pesquisa. 2012; 42(146), 351-367.

Hughes EC. Le regard sociologique. Textes choisis et traduits par J-M Chapoulie. Paris: l'EHESS, 1996.

Johnson M, Cowin LS, Wilson I, Young $H$. Professional identity and nursing: contemporary theoretical developments and future research challenges. Int Nurs Rev. 2012 Dec 59(4), 562-9.

Kaufmann JC. A invenção de si: uma teoria da identidade. Lisboa: Instituto Piaget; 2004.

Kemmer LF, Silva MJP. Como escolher o que não se conhece? Um estudo da imagem do enfermeiro por alunos do ensino médio. Acta paul. enferm. [Internet]. 
2007a. [citado 2014 out 17]; 20(2): 125-130. Disponível em: http://www.scielo.br/pdf/ape/v20n2/a03v20n2.pdf

Kemmer LF, Silva MJP. A visibilidade do enfermeiro segundo a percepção de profissionais da comunicação. Rev Latino-am Enfermagem. [Internet]. 2007b Abr; [citado 2015 Ago 10]; 15(2): 191-8. Disponível em: http://www.scielo.br/pdf/rlae/v15n2/pt v15n2a02.pdf

Lemos CG, Bueno JMH, Silva PL, Genicolo VC. Referenciais de carreira e identidade profissional em estudantes universitários. Psicologia ciência e profissão, 2007, 27(2): 208-223.

Lemos E. Profissão de enfermeiro: compreensão sociológica da identidade profissional [dissertação]. Porto: Universidade do Porto; 2008.

Lima MJC. Neoliberalismo e educação. Studia Diversa, CCAE-UFPB. 2007 Out; 1(1): 44-61.

Lima PG. Políticas de educação superior no Brasil na primeira década do século XXI: alguns cenários e leituras. Avaliação: Rev. da Avaliação da Educação Superior (Campinas). 2013; 18(1): 85-105.

Lima TS, Santos RS, Gubert FA, Neto Lima PJ, Freitas MC. Motivação no trabalho do enfermeiro: estudo realizado em instituições hospitalares de João Pessoa, Paraíba, Brasil. Rev enferm UFPE [Internet]. 2009 Abr-Jun; [citado 2015 Ago 10]; 3(2):275-81. Disponível em: http://www.revista.ufpe.br/revistaenfermagem/index.php/revista/article/viewFile/292/p df 866

Lopes CHAF, Jorge MSB. Interacionismo simbólico e a possibilidade para o cuidar interativo em enfermagem. Rev Esc Enferm USP 2005; 39(1):103-8.

Luchesi LB, Mendes IAC, Shiniyashiki GT, Costa JML. Elaboração de instrumento para análise da imagem do enfermeiro frente a alunos do ensino médio. Rev. esc. enferm. USP [Internet]. 2009 Junho [citado 2015 Jul 14]; 43(2): 272-278. Disponível em: http://www.scielo.br/pdf/reeusp/v43n2/a03v43n2.pdf

Luchesi LB, Mendes IAC. Questionário multidimensional para análise da imagem do enfermeiro. Acta paul. enferm. [Internet]. 2010 [citado 2015 Jun 25]; 23(1): 16-22. Disponível em: http://www.scielo.br/pdf/ape/v23n1/03.pdf

Luchesi LB; Lopes GT. História oral. In: Oguisso T, Souza Campos PF, Freitas GF, organizadores. Pesquisa em História da Enfermagem. $2^{\underline{a}}$ ed. Barueri: Manole; 2011. Série Enfermagem e Saúde. p. 401-56.

Luna SV. Planejamento de pesquisa: uma introdução. $2^{\underline{a}}$ ed. São Paulo: EDUC; 2013.

Marre JL. História de vida e método biográfico. Cad de Sociologia. 1991. Porto Alegre, UFRGS; 3(3): 89-141. 
Martins ACP. Ensino superior no Brasil: da descoberta aos dias atuais. Acta Cir. Bras. [Internet]. 2002 [citado 2015 Jul 14]; 17(Suppl 3): 04-06. Disponível em: http://www.scielo.br/pdf/acb/v17s3/15255.pdf

Mecone MCC, Freitas GF. Representações da enfermagem na imprensa da Cruz Vermelha Brasileira (1942-1945). Texto contexto - enferm. [Internet]. 2009 Dez [citado 2015 Jul 01]; 18(4): 741-749. Disponível em: http://www.scielo.br/pdf/tce/v18n4/16.pdf

Medeiros M, Tipple ACV, Munari DB. A expansão das escolas de enfermagem no Brasil na primeira metade do século XX. Revista Eletrônica de Enfermagem. [internet]. Goiânia 1999 Out-Dez [citado 2015 Jul 14]. 1(1). Disponível em: http://h200137217135.ufg.br/index.php/fen/article/view/666/736

Meihy JCSB. Canto de morte Kaiowá: história oral de vida. São Paulo: Loyola; 1991.

Melo IF. Análise do discurso e análise crítica do discurso: desdobramentos e intersecções. Rev. Eletrônica de Divulgação Científica em Língua Portuguesa, Linguística e Literatura. 2009 Set; 5(11): 1-18.

Monteiro BA. Diretrizes e bases da educação nacional e escolas de enfermagem da década de 1960: uma visão histórica [dissertação]. São Paulo, Escola de Enfermagem, Universidade de São Paulo; 2009.

Moreira A. Profissionalização da enfermagem: o pioneirismo da Escola de Enfermagem Alfredo Pinto (1890-1920) [tese]. São Paulo: Escola de Enfermagem, Universidade de São Paulo; 2003.

Moreira A. Profissionalização da enfermagem brasileira. In: Trajetória histórica da enfermagem. Oguisso T, organizadora. São Paulo, Barueri: Manole; 2014. p. 123-46.

Moreira A, Oguisso T. Profissionalização da enfermagem brasileira. Rio de Janeiro: Guanabara Koogan; 2005.

Mott ML. Revendo a história da enfermagem em São Paulo (1890-1920). Cadernos PAGU 1999; (13): 327-55.

Netto LFSA, Ramos FRS. Considerações sobre o processo de construção da identidade do enfermeiro no cotidiano de trabalho. Rev. Latino-Am. Enfermagem [Internet]. 2004 Fev [citado 2015 Jul 14]; 12(1): 50-57. Disponível em: http://www.scielo.br/pdf/rlae/v12n1/v12n1a08.pdf

Neto LD, Nóbrega MML. Holismo nos modelos teóricos de enfermagem. Rev. Bras. Enferm., 1999 abr-jun. Brasília; 52(2): 233-42.

Oguisso T, Campos PFS, Moreira CA. Enfermagem pré-profissional no Brasil: questões e personagens Enfermagem em Foco 2011; Supl2:S368-72.

Oguisso T. Trajetória histórica e legal da enfermagem. $2^{\underline{a}}$ ed. São Paulo. Barueri: Manole; 2005. A influência francesa na enfermagem brasileira, pp. 130-155. 
Oguisso T. Trajetória histórica e legal da enfermagem. $2^{\underline{a}}$ ed. ampl. São Paulo, Barueri: Manole, 2007. As origens da prática do cuidado, pp. 12-14.

Oguisso T. Trajetória histórica da enfermagem. São Paulo, Barueri: Manole; 2014. Florence Nightingale.

Oxtoby K. Men in nursing. Nurs Times. 2003; 99(32):20-3.

Padilha MICS. A mística do silêncio: a enfermagem na Santa Casa de Misericórdia do Rio de Janeiro no século XIX. Pelotas: Universitária/UFPel; 1998.

Padilha MICS, Borestein MS. O método de pesquisa histórica na enfermagem. Texto \& Contexto Enferm. 2005; 14(4): 575-84.

Padilha MI, Nelson S, Borenstein MS. As biografias como um dos caminhos na construção da identidade do profissional da enfermagem. Hist. cienc. saudeManguinhos [Internet]. 2011 Dez [citado 2015 Jun 26]; 18(Suppl 1): 241-252. Disponível em: http://www.scielo.br/pdf/hcsm/v18s1/13.pdf

Pai DD, Schrank G, Pedro ENR. O enfermeiro como ser sócio-político: refletindo a visibilidade da profissão do cuidado. Acta paul. enferm. [Internet]. 2006 Mar [citado 2015 Ago 10]; 19(1): 82-7. Disponível em: http://www.scielo.br/pdf/ape/v19n1/a13v19n1.pdf

Parsons E. A enfermagem moderna no Brasil. Esc Anna Nery Rev Enferm. 1997 jul; 1(1): $10-24$.

Passos ES. De anjos a mulheres. Ideologias e valores na formação de Enfermeiras. Salvador: EDUFBA/EGBA; 1996.

Paterson JE, Zderad LT. Enfermería humanística. Ciudad de México (MEX): Editorial Limusa S.A.; 1979 apud Castanha ML, Zagonel IPS. A prática de cuidar do ser enfermeiro sob o olhar da equipe de saúde. Rev. bras. enferm. [Internet]. 2005 Out [citado 2015 Mai 14]; 58(5): 556-62. Disponível em: http://www.scielo.br/pdf/reben/v58n5/a11v58n5.pdf

Percheron A. L'univers politique des enfants. Colin; 1974 apud Dubar C. A Socialização: construção das identidades sociais. Portugal: Porto; 1997.

Ribeiro AA, Falcon GS, Borenstein MS, Padilha MICS. A escolha profissional no imaginário social - enfermeiras brasileiras e peruanas. Esc. Anna Nery [Internet]. 2006 Ago [citado 015 Mai 15]; 10(2): 241-250.

Ristoff D. O novo perfil do campus brasileiro: uma análise do perfil socioeconômico do estudante de graduação. Avaliação: Revista da Avaliação da Educação Superior (Campinas) 2014, 19(3), 723-747.

Rodrigues ACL, Bormio SNG. Escolha profissional: tarefa complexa na adolescência? In: Anais do $2^{\circ}$ Simpósio Internacional de Educação Linguagens: perspectivas interdisciplinares na atualidade; 2008 Jul; Bauru (SP) [internet]. Bauru 
(SP): Universidade do Sagrado Coração; 2008 [citado 2015 abr 10]. Disponível em: http://www.usc.br/biblioteca/pdf/sie 2008 psic arti escolha profissional tarefa com plexa.pdf

Rodrigues MR. Enfermagem compreendida como vocação e sua relação com as atitudes dos enfermeiros frente às condições de trabalho. Rev Latino-am Enfermagem. 2001. novembro-dezembro; 9(6):76-82.

Rodrigues ML. Sociologia das Profissões, $2^{\mathrm{a}}$ ed. Oeiras, Portugal: Celta; 2002.

Roscani ANCP, Guirardello EB. Demandas de atenção no ambiente de trabalho e capacidade de direcionar atenção do enfermeiro. Rev. Latino-Am. Enfermagem [Internet]. 2010 Ago [citado 2015 Jul 17]; 18(4): 778-85.

Sacramento NA, Nascimento ER. Racismo e saúde: representações sociais de mulheres e profissionais sobre o quesito cor/raça. Rev. esc. enferm. USP. 2011; 45( 5 ): $1142-9$.

Salomé GM, Martins MFMS, Espósito VHC. Sentimentos vivenciados pelos profissionais de enfermagem que atuam em unidade de emergência. Rev. bras. enferm. [Internet]. 2009 Dez [citado 2015 Mai 14]; 62(6): 856-62. Disponível em: http://www.scielo.br/pdf/reben/v62n6/a09v62n6.pdf

Sampaio H. O setor privado de ensino superior no Brasil: continuidades e transformações. Rev. Ensino Superior Unicamp. [internet]. 2011 Out [citado 2015 jul 14]; 4a ed.: 28-43. Disponível em: http://www.revistaensinosuperior.gr.unicamp.br/edicoes/ed04 outubro2011/05 ARTI GO PRINCIPAL.pdf

Sampaio H. Ensino superior no Brasil. O setor privado. São Paulo: Hucitec; 1999.

Santos CB; Luchesi LB. A imagem da enfermagem frente aos estereótipos: uma revisão bibliográfica. In: Anais do $8^{\circ}$ Simpósio Brasileiro de Comunicação em Enfermagem [Proceedings internet]; 2002 Maio 2 - 3; São Paulo [citado 2015 ago 10]. Disponível em: http://www.proceedings.scielo.br/pdf/sibracen/n8v2/v2a073.pdf

Spindola T, Moreira A. O aluno e a enfermagem: por que esta opção profissional? Esc Anna Nery Rev Enferm. 1999 Dez; 3(3): 25-36.

Severino AJ. O ensino superior brasileiro: novas configurações e velhos desafios. Educar, Editora UFPR. Curitiba, 2008; (31): 73 - 89.

Siles Gonzáles J, Oguisso T, Freitas GF, Souza Campos PF. Cultura de los cuidados: Historia de la enfermería ibero-americana. Alicante, Espanha: editorial club universitário; 2010. pp.77-96

Silva AL, Padilha MICS, Borenstein MS. Imagem e identidade profissional na construção do conhecimento em enfermagem. Rev. Latino-Am. Enfermagem [Internet]. 2002 Jul [citado 2015 Jul 14]; 10(4): 586-595. Disponível em: http://www.scielo.br/pdf/rlae/v10n4/13372.pdf 
Silva GB. Enfermagem profissional: análise crítica. São Paulo: Cortez, 1986. 143p.

Silva IL, Almeida ACMT, Romero E, Beresford H. Percebendo o corpo que aprende: considerações teóricas e indicadores para avaliação da linguagem não-verbal de escolares do $1^{\circ}$. ciclo do ensino fundamental. Ensaio: aval.pol.públ.Educ., [internet]. Rio de Janeiro 2004 [citado 2015 junh 18]; 12(45): 995-1012. Disponível em: http://www.scielo.br/pdf/ensaio/v12n45/v12n45a06.pdf

Souza Júnior JGC, Cavalcanti ATA, Monteiro EMLM, Silva MI. Como será o amanhã? responda quem puder! perspectivas de enfermeirandos quanto ao seu futuro profissional. Revista Brasileira de Enfermagem. [internet]. 2003. [citado 2015 jul 14]; 56(4), 453-458. Disponível em: http://www.scielo.br/pdf/reben/v56n4/a31v56n4.pdf

Strauss A. Espelhos e máscaras: a busca da identidade. São Paulo: Universidade de São Paulo; 1999.

Takashi MH. Movimento da enfermagem paulista na década de 1940: reformulação do ensino profissional [dissertação]. São Paulo, Escola de Enfermagem, Universidade de São Paulo; 2011.

Teixeira E, Vale EG, Fernandes JD, Sordi MRL. Trajetória e tendências dos Cursos de Enfermagem no Brasil. Rev Bras Enferm 2006a Jul-Ago; 59(4): 479-87.

Teixeira E, Vale EG, Fernandes JD, Sordi MRL. Enfermagem. In: Haddad AE, Pierantoni CR, Ristoff D, Xavier IM, Giolo J, Silva LB, organizadores. A trajetória dos cursos de graduação na área da saúde: 1991-2004. Brasília (DF): Instituto Nacional de Estudos e Pesquisas Educacionais Anísio Teixeira; 2006b. p. 141-168.

Teixeira E, Vale EG, Fernandes JD, Sordi MRL. Trajetória e tendências dos Cursos de enfermagem no Brasil. Rev Bras Enferm 2006a jul-ago; 59(4): 479-87.

Thives PF. As vozes sociais na constituição da identidade docente. In: Anais do $7^{0}$ Seminário de Pesquisa em Educação da Região Sul; 2008 jun. 22 - 25; Itajaí. Itajaí: UNIVALE; 2008. p. 2 - 7.

Vieira MJ. A representação do cuidar na imagem cultural da enfermagem. Rev. Latino-Am. Enfermagem [Internet]. 1999 Dez [citado 2015 Jun 26]; 7(5): 25-32. Disponível em: http://www.scielo.br/pdf/rlae/v7n5/13501.pdf

Vieira L. Identidade e globalização: impasses e perspectivas da identidade e a diversidade cultural. Rio de Janeiro: Record, 2009.

Villaverde A. Resgate Histórico e afirmação do movimento estudantil. In: Ditadura de Segurança Nacional no Rio Grande do Sul (1964-1985): história e memória. Padrós Es, Barbosa VM, Lopez VA, Fernandes AS. Porto Alegre: Corag; 2009. p. 171-80. 
APÊNDICES 


\section{APÊNDICE A - Instrumentos de coleta de dados}

\section{Parte 1. Perfil sócio-demográfico dos participantes}

1. Sexo:

2. Etnia:

3. Religião:

4. Ensino fundamental ( ) instituição pública ( ) privada

5. Ensino médio ( ) instituição pública ( ) privada

6. Trabalha como auxiliar ou técnico de enfermagem? ( ) sim ( ) não

7. Se sim à questão 6 , diga há quanto tempo vc trabalha nessa função:

\section{Residência habitual}

Endereço:

Telefone:

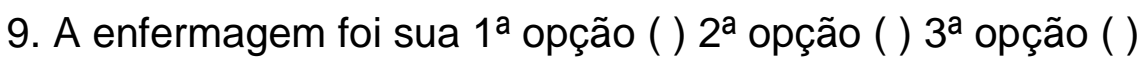

10. Possui algum tipo de bolsa estudantil? ( ) Sim （） não. Qual?

11. Procedência (Estado, Município e região do país):

12. Estado civil: ( ) solteiro ( ) casado ( ) divorciado ( ) viúvo ( ) outros:

13. Vive com ( ) pais ( ) amigo/a ( )irmãos ( ) outros parentes

14. Tem filhos ( ) sim ( ) não

15. Se sim à questão 14, os filhos vivem ( ) com você （） com seus pais ( ) com a mãe das crianças

16. Data de nascimento:

17. Nacionalidade:

18. Vínculo empregatício: ( ) sim ( ) não. Se sim, qual a área de atuação (especificar) e qual o cargo/função:

19. Jornada diária de trabalho ( $\mathrm{n}$ - de horas):

20. Quantas pessoas integram a família:

21. Quem é o responsável pela família:

22. Quem trabalha na família (quantas pessoas):

23. Qual a receita total da família:

24. Se reside no município de São Paulo, qual o bairro?

25. A que distância sua residência fica, aproximadamente, do trabalho?

26. A que distância você mora da Faculdade onde estuda? 
27. Você tem dependentes (economicamente)? Quantos?

28. Quantas horas por semana, em média, você dedica aos trabalhos acadêmicos (leituras, estudos, etc)?

29. Atividades de lazer: o que você faz nas horas vagas? ( ) faço esportes ( ) passeio ( ) vejo TV ( ) vou ao cinema ( ) faço visitas a amigos e familiares ( ) outros: definir qual:

\section{Parte 2. Questões norteadoras}

1. O que é ser enfermeiro para você?

2. Conte-me como se deu sua opção pela enfermagem?

3. Como seus familiares, amigos e cônjuge (se tiver) encaram/percebem sua escolha?

4. O que você espera do futuro da profissão, como enfermeiro? 


\section{APÊNDICE B - Termo de Consentimento Livre e Esclarecido}

\section{Item 1. Registro dos esclarecimentos do pesquisador aos participantes da pesquisa.}

Eu, Thaís Araújo da Silva, mestranda em Enfermagem, do Programa de PósGraduação em Gerenciamento em Enfermagem, sob a orientação do Prof. Dr. Genival Fernandes de Freitas, venho convidá-lo (a) a participar da pesquisa intitulada "Identidade e escolhas profissionais na perspectiva de graduandos de enfermagem". Esta investigação tem por objetivos: Mapear e discutir o perfil sóciodemográfico do alunado matriculado no curso de enfermagem da Instituição Superior de Ensino Privado, do Município de São Paulo, local do estudo, referente ao ano de 2014, conhecer e compreender as percepções e significados atribuídos à identidade do ser enfermeiro a partir das experiências de estudantes de enfermagem de uma instituição de ensino superior privada do Município de São Paulo e analisar as motivações e razões apontadas pelos estudantes de Enfermagem, colaboradores desse estudo, relativas à escolha pelo curso de Enfermagem.

Para tanto, será realizada uma entrevista que deverá ser gravada em dia e horário definidos de acordo com a disponibilidade do colaborador do estudo. A entrevista será confidencial, sigilosa e o seu depoimento estará sob a nossa responsabilidade e terá a duração aproximada de duas horas.

O conteúdo da entrevista será utilizado apenas para a realização do estudo, podendo os resultados ser apresentados em eventos e publicados em revistas científicas. A participação dos colaboradores do estudo será totalmente voluntária, podendo os mesmos deixá-lo a qualquer momento que desejarem. Caso aceite participar desta pesquisa, solicito a sua assinatura no item II deste documento.

Segundo a Resolução 466/12 do Conselho Nacional de Saúde, o respeito devido à dignidade humana exige que toda pesquisa se processe após consentimento livre e esclarecido e, no caso de crianças e adolescentes ou legalmente incapaz também do assentimento dos sujeitos, indivíduos ou grupos que por si e/ou por seus representantes legais manifestem a sua anuência à participação na pesquisa.

Desde já agradeço a sua atenção e coloco-me à disposição para quaisquer esclarecimentos sobre a pesquisa. O meu telefone para contato é (011) 97981-5433 
(e-mail: taarsi2@hotmail.com) e o do Comitê de Ética em Pesquisa da Escola de Enfermagem da Universidade de São Paulo é (011) 3061-7548 (e-mail: edipesq@usp.br).

O documento será disponibilizado em duas vias, ficando uma delas com o colaborador e a outra com o pesquisador.

São Paulo, de de 2015. 


\section{Item 2. Autorização do colaborador}

Compreendo o objetivo desta pesquisa e concordo em participar de forma voluntária da mesma, entendendo que as informações serão confidenciais, que não haverá identificação nominal e que não sofrerei qualquer tipo de sanção ou prejuízo, caso desista de participar deste estudo. Declaro, ainda, que ao ser convidado a participar desta pesquisa, todos os esclarecimentos foram prestados pelo pesquisador.

São Paulo, de

de 2015.

Colaborador 


\section{APÊNDICE C - Entrevistas transcriadas}

\section{Participante 1}

Ser enfermeiro para mim é uma honra, primeiro de tudo. É ter uma consciência e poder cuidar do próximo, ter amor, ter zelo, responsabilidade acima de tudo e honrar aquilo que você faz a pátria, ser o enfermeiro. Ser enfermeiro é cuidar, zelar o próximo.

A escolha pela enfermagem ocorreu por conta de ver as situações dentro do meu lar. Escolhi essa profissão, primeiro de tudo, para ajudar o próximo, para eu poder ser útil dentro do meu lar, no meio dos meus familiares, poder ajudar meus vizinhos, e enfim, ajudar uma sociedade que precisa de bons profissionais qualificados. Escolhi, também, porque tenho uma mãe que é idosa e ela tem problema de pressão, é hipertensa. Assim, devido a idade e por ela passar mal, escolhi ser enfermeira para poder ajudá-la, porque posso utilizar essa profissão, então, vou ser útil dentro da minha casa mesmo. Passei por dificuldades dentro do meu lar. Perdi algumas pessoas que eu não pude ser útil, porque eu não tinha conhecimento da enfermagem.

Hoje tenho um pouco mais de conhecimento. Quando percebo que minha mãe está com problema de pressão, verifico sua pressão, pego o aparelho e já vou automaticamente adiantando o atendimento pra encaminhá-lá ao AMA ou para um hospital. Se um vizinho precisar solicitar um auxílio, vou ser útil também. Essa profissão abrange tudo. Primeiro de tudo é você ser útil. Você passa por processos que acaba automaticamente escolhendo. Também, perdi meu sogro. Ele teve infelizmente um infarto. Como estou em São Paulo com meu noivo, ele mora na Bahia, ele demorou para ser atendido. Da casa dele para o hospital, demorou duas horas e ele não suportou. Não tinha profissionais qualificados, profissionais para estar dando os primeiros socorros e ele veio a falecer. Então, são situações que passamos dia a dia que mexem conosco e a enfermagem é você dar sua vida, você vê o seu próximo, em qualquer lugar, dentro do ônibus, dentro do mercado é até mesmo dentro da faculdade, é onde você está. Você vê um ser humano passando mal, você acaba sentindo a dor dele. E a enfermagem é isso, sempre tem que olhar adiante do que você está vendo. Se eu posso ajudar uma pessoa, por que não ajudar? Tudo o que tenho aprendido é colocar em prática. Se hoje estou estudando 
enfermagem é porque eu vou ser útil para alguém amanha em alguma situação.

Antes de entrar na enfermagem, trabalhei numa barraca durante sete anos com a minha mãe, que até hoje ela é viva, graças a Deus! Ali eu sofri muito porque eu era vendedora autônoma com minha mãe. Acordava por volta de três horas da madrugada para fazer bolos, salgados, cafés, enfim, todo aquele preparo porque eu tinha horário para tá subindo aquela barraca e essa barraca era fora do posto de saúde. Ali, vivenciei muitas situações, pessoas viciadas, drogadas, desempregadas e fui vendo como era importante cuidar e zelar do próximo. Fiquei quase seis anos debaixo de sol, de chuva. Presenciei muitos assaltos, muitos jovens nas drogas e aquilo ali foi me dando uma segurança e amor pela enfermagem. Ali eu falei: "por que não fazer enfermagem? "Fui próximo da minha casa, fiz o auxiliar e técnico e agora estou na faculdade. Para mim, estudar era impossível, porque na época eu estava desempregada e nessa barraca que eu trabalhava eu tirava menos do que $R \$ 300,00$ e a mensalidade do curso de auxiliar, quando eu comecei na época, era quase 200 e eu estava desempregada. Eu falava: "Meu Deus como eu vou tirar esse dinheiro?" E aí o Senhor preparou um serviço. Iniciei trabalhando em uma clínica geriátrica que estou até hoje. Ali, fui pegando gosto, amor. Cuido de dezoito pacientes com problema de Alzheimer, AVC e Parkinson. Elas têm idade de ser minha avó, eu tenho idade de ser neta delas. Cuido delas como se cuidasse da minha própria mãe da minha própria avó. A gente aprende com isso, porque o ser humano é cheio de limitações, lidar com o ser humano não é fácil, mas na área da enfermagem a gente supera tudo. A gente vê muitas coisas, a gente tem que se colocar no lugar da pessoa (um vizinho seu, um parente seu, uma mãe sua, um pai seu, um esposo seu). Então, cuido delas como se fosse a minha própria família, não só pelo dinheiro, porque o dinheiro resolve, mas quando você está nessa profissão, você tem que ter amor, carinho, tem que saber entendê-las, saber ouvi-las. Há momentos que elas querem que você converse com elas, querem carinho, porque elas estão em um ambiente fechado, é uma clínica particular, mas ali elas sentem falta da família, então nós acabamos sendo família delas. Hoje eu to contente, tenho tentado me realizar profissionalmente e estou aí para aprender. To trilhando um novo sucesso para minha vida cada dia mais.

Quando resolvi fazer a faculdade de enfermagem, uns falaram: "Que loucura! Depois que você começou a fazer enfermagem, mal tem tempo para nós", mas por outro lado a minha mãe, os meus irmãos, o meu noivo, me incentivaram. Tenho 
muito apoio do meu noivo: "Vai em frente, as dificuldades virão, os obstáculos, mas você vai superar tudo isso, porque tudo é uma fase". Lógico todos passamos dificuldades, mas dentro dessa dificuldade eu vou ser uma grande profissional, porque nada vem fácil. A partir do momento que tem uma barreira é aí que você tem que ultrapassar e falar: "Eu vou vencer, vou ser uma vencedora, uma guerreira no meio dos meus familiares, dos meus vizinhos, da minha religião". Tenho muito apoio do meu pastor, das irmãs. Enfim, tenho tido apoio de muitos lados. A gente tem que se dedicar mais aos estudos, mas eu procuro ter tempo para o noivo, para a família e para os amigos. Tive outros amigos/famílias que disseram: "Você tá doida, você vai fazer enfermagem? Por que você não escolhe psicologia? Por que você não escolhe outra área? Você vai ficar praticamente num plantão doze horas. E seu noivo? Futuramente você vai casar. Sua mãe?" (Quando resolvi fazer a faculdade de enfermagem, uns falaram: "Que loucura! Depois que você começou a fazer enfermagem, mal tem tempo para nós", mas procuro não levar esse lado negativo, procuro olhar o lado positivo, porque os "Nãos" da vida faz com que você cresça tanto profissionalmente, como financeiramente. Nem tudo você sempre leva o sim. Entre sim e o não, muitas vezes você leva o não. Eu levei muitos nãos, mas esses nãos têm me fortalecido. Amanhã vou mostrar para essas pessoas que não acreditaram e não acreditam no meu potencial que logo vou estar uma enfermeira formada e vou poder ser útil e ajudar minha nação.

Eu espero um futuro melhor, uma enfermagem mais aceita, respeitada. Ter mais investimentos nos postos de saúde e nos hospitais. Ter oportunidade de emprego que muitas vezes é uma coisa restrita. Ter mais oportunidades, porque nosso governo precisa investir mais na área da saúde. A saúde, entre aspas, está em caos. Se você entra nos hospitais, nos AMAs, nos postos de saúde, você vê idosos em pé, vê idosos horas e horas para ser atendido. Você vai num hospital, não tem médico, não tem uma equipe qualificada para estar atendendo. Eles medicam o paciente e fala: "Vai para casa, depois procura uma UBS".

Espero ser uma enfermeira útil, com uma visão ampla. Ter estudos no exterior, ter bolsas e oportunidades, pois nem todos nós podemos pagar uma PUC, uma Mackenzie, porque nossas condições não favorecem e nosso governo esquece. Pra você ter hoje um profissional qualificado ele tem que ter condições para ter um bom estudo e um bom rendimento dentro de uma faculdade.

Espero depois de formada trabalhar em hospitais bons, que me favoreça 
conhecimento. Tem muitos hospitais bons, top, de linha um, como: Albert Einstein, Sírio Libanês. A minha vontade é crescer profissionalmente, ajudar minha família, minha mãe. Dar boas condições financeiras para ela. $O$ tempo que ela tiver de vida, oferecer uma vida melhor. Poder comprar meu carro, minha casa própria. Eu estudo hoje para amanhã estar colhendo e plantando coisas boas. Para entrar nesses hospitais (Albert Einstein, Sírio Libanês) e nos estrangeiros, tem que ter uma boa qualificação, tem que ter cursos, inglês ou francês fluente. E hoje com os custos com a faculdade não tem como cursos de línguas, pois nossas condições não dão. Espero ser enfermeira e ficar bem profissionalmente e financeiramente para eu ajudar meu próximo, ajudar minha mãe. Ela criou seis filhos, veio do Nordeste. Meu pai foi embora, deixou minha mãe, eu tinha um aninho de idade. Não tive a oportunidade de conhecer meu pai e minha mãe foi uma guerreira, minha mãe não deu ninguém. Há vinte cinco anos atrás, você imagina o que minha mãe passou, chegando do norte, com três filhos, eu sou a mais nova. Minha mãe teve que deixar meus irmãos sozinhos e teve que encarar casa de família, faxina. Ela trabalhava em dois serviços, em casa de família e em uma fábrica. Ficávamos sozinhos, trancados, minha fazia a tupperware de cada um, desligava o gás. Hoje todos os meus irmãos são formados. Tenho dois irmãos que são contadores, um engenheiro civil, um que formou em segurança do trabalho e logo eu enfermeira. Se você crê e acredita em sonhos, não desista! 


\section{Participante 2}

Ser enfermeiro para mim é muito gratificante. Sempre quis desde novinha trabalhar na área da saúde, ser enfermeira, mas aí a gente vai ficando mais adulta e vai ficando meio perdida, que é aquela idade entre os dezesseis/dezessete/dezoito anos, ai pronto, seu sonho acaba porque você quer fazer molecagem, quer ir para a bagunça. Eu esqueci um pouco o sonho da enfermagem. Casei-me, fui tendo meus filhos, que são somente sete, seis homens e uma menina e foi ficando inviável por conta das crianças. Eu tinha parado na sétima série e foi ficando complicado. Quando eu estava no meu sexto filho, resolvi voltar a estudar. No comecinho da gravidez fui fazer a sétima e oitava. Fiz a sétima e oitava. Quando me formei, no outro dia eu ganhei meu bebê. No outro ano comecei a fazer o primeiro e o segundo. Trabalhava como doméstica. Nesse interim eu engravidei da minha filha, tive que parar. Tinha um outro filho pequeno que não tinha nem dois anos e fiquei grávida da menina e marido nessas horas só serve para encher o saco, ai eu parei. Quando dei a luz a menina, eu voltei para a escola. Fui tentar fazer o normal pra recuperar, porque você ganha mais em conhecimento, mas acabou não dando, eu perdi mais meio ano, mas depois eu fiz supletivo e o auxiliar de enfermagem e falta só uma prova para eu terminar o técnico, mas estou pensando seriamente em não fazer essa prova e ficar somente com o auxiliar. Foi passando o tempo, fui trabalhando em casa de repouso. Me identifiquei com a área geriátrica, gosto muito dessa área. Eu não gostava, por incrível que pareça, de lidar com gente de idade, sempre respeitei, mas para lidar eu sentia meio que assim, um asco, mas meu marido ficou desempregado e eu tinha que trabalhar. Eu não queria mais trabalhar como doméstica. Uma amiga falou: "tem uma casa de repouso que está precisando de uma auxiliar". Eu pensei: "casa de repouso?!", mas a necessidade faz o ladrão, então, fui. Na segunda semana já estava apaixonada por aqueles idosos. Mudei totalmente minha visão em relação a eles e à família deles. Pensava que a família deixava os idosos largados em uma casa de repouso, para mim, até então, eram como filhos desnaturados. Existem casos que a família não tem responsabilidade nenhuma, mas fui vendo que às vezes o psicológico da pessoa não aceita ver um ente querido (um pai, uma mãe, às vezes até um irmão, pois tem gente nova com problema psicológico/psiquiátrico. Dentro de casa, com saúde, forte bonito, mas perturbado). Fui mudando meu conceito por esse lado e entendendo melhor. 
Quando eu resolvi ir mesmo para enfermagem foi há oito anos. Meu pai faleceu em casa. Ele nunca teve problema de saúde. Nunca o vi doente. Ele nunca bebeu, nunca fumou. Tinha carro, mas preferia andar a pé. Ele tinha um problema com a embolia pulmonar e mexia muito nas coisas. Ele deve ter caído e tido uma pancada e não comentou com a gente. A gente sempre o observava fazendo uma massagem do lado assim (pôs a mão em suas costas). A gente perguntava e ele falava que não era nada e fazia um chá. Meu pai nunca gostou de hospital. Num sábado ele foi dormir e não acordou. Morreu praticamente dormindo. Naquele dia tive que tomar a frente. Meu pai era de levantar cedo, já era umas 9 horas e ele ainda não tinha levantado. Minha mãe foi me chamar dizendo que ele ainda estava dormindo. Quando eu vi o horário, logo deduzi que tinha acontecido alguma coisa e quando eu cheguei lá, pude perceber que ele já tinha falecido fazia algum tempo. Chamei o SAMU, mesmo sabendo que eles não iam levar por conta da situação, mas tive que fazer todo aquele enredo pra poder amenizar a preocupação da minha mãe. Quando eles chegaram lá a médica falou: "sinto muito, ele faleceu e tem que esperar o carro do IML retirar". Como tinha muita criança, eu conversei com a doutora e perguntei se não tinha como retirar. Ela simulou uma parada cardíaca e levou ao hospital mais próximo e eu fui junto. Eu não era auxiliar ainda.

Chegamos no hospital como se fosse uma parada. Fizeram todos os procedimentos de uma parada cardíaca e o médico do PS veio falar que meu pai havia falecido, mas eu já sabia. Foi quando despertou de fato em mim, aquilo que estava adormecido. Ele queria (se referindo ao pai) que eu fosse militar, mas eu sempre gostei da área da saúde, de lidar com os outros, de fazer curativo, de cuidar. Eu ia para posto de saúde, e lá é um lugar que a gente tem mais contato com o enfermeiro. Desde pequena eu via aquele ser de branco que vinha me dar injeção. A princípio eu tinha, como toda criança tem, aquele medo, depois vinha a raiva, mas com o passar dos anos eu fui vendo de outra forma, a forma que se tratava das pessoas. Sempre tem um espírito de porco, mas eu pude conviver com pessoas da enfermagem muito boas. Lembro que tinha uma enfermeira na rua de casa que fazia tudo, era como se fosse uma médica. Se alguém ficasse doente, podia ser a hora que fosse, ela ia, fazia o básico, via a febre, medicava com dipirona. Hoje em dia se chama médico da família, que vai todo aquele pessoal. Ela fazia todo esse papel, de orientar a pessoa, encaminhar para o médico, para o posto. Às vezes a criança tinha alguma ferida, ela cuidava, mas mandava a mãe levar no posto, porque não ser 
somente um machucadinho, podia ser outra coisa. E aquilo me atraía nela, eu a achava a pessoa mais importante. Ela dava conselho. Às vezes ela era chata com aquele negócio de não pôr a mão na boca, não sei o que com unha, não andar descalço, não pisar no esgoto, "vai limpar esse machucado!"; "olha essa boqueira, se você não cuidar vai virar uma ferida enorme!". Mas a gente gostava muito dela. Eu tinha uma admiração quando eu a via saindo para trabalhar toda de branco, eu achava o máximo, não aquela coisa assim que o pessoal põe, aquela coisa vaidosa, mas do profissional mesmo. Assim como eu tenho admiração pelos militares não por serem bonitos (risos), mas o respeito que a farda impõe, independente ser polícia, exército, aeronáutica. Tive um farmacêutico de bairro, ele era o socorro de todo mundo. Fui tendo essa admiração pelo lado da saúde. Nas escolas, na minha época, tinha dentista. Aquilo foi me atraindo essa parte de lidar com o ser humano. Nunca quis ser médica, veio me atrair um pouco antes de fazer enfermagem, a cirurgia bucal, que eu acho interessante, mas não deu certo, acho que não era pra ser. Agora eu vim resgatar meu sonho que é ser enfermeira que antigamente falava enfermeira padrão. Hoje não usa mais esse termo "enfermeira padrão". Eu falava: "quando eu voltar a estudar, quero ser enfermeira padrão". Por conta, também, da responsabilidade. Tem que gostar. Os meus amigos falam: "se for pelo dinheiro, eu pegaria meu material, descia e trocava de curso, porque não ganha bem". Eu sei que não ganha bem. Pra mim, vida não tem preço. Tenho meus filhos e eu dependi muito de enfermeiro, de auxiliar, de técnico. Quando acontece alguma coisa, quem recebe a gente no PS, são os enfermeiros. Você fica internado, quem cuida, são os enfermeiros. E com tudo isso, fui gostando mais ainda quando eu tive meu bebê. Tinha que levar no hospital, ficar na internação. Via todo aquele cuidado de enfermagem e aquilo me atraía demais ver o cuidar, o zelo. De vez em quando tinha um espírito de porco, mas todo lugar tem. Na família tem os cunhados, a gente tem que suportar (risos).

Depois que iniciei o trabalho na Casa de Repouso, juntou o Lé com o Cré. Eu já queria fazer enfermagem mesmo há muitos anos, pensei: "vou tentar fazer a faculdade". Só que os horários não ajudavam, plantão de doze horas, às vezes a casa de repouso precisava eu tinha que virar 24 horas. Pensei em esperar mais um pouco. Foi aí que sai da casa de repouso, porque fechou e uma amiga minha me chamou para trabalhar na Faculdade onde estudo, no setor comercial. Vim trabalhar e vi a oportunidade de cursar a graduação em enfermagem. la fazer odonto em 
Guarulhos, pois a parte comercial se encontrava no Tucuruvi. Para eu ir do Tucuruvi para Guarulhos era mais fácil. E como lá tem cirurgia bucomaxilar, interessou-me. É uma área bonita que eu gosto, mas só tinha no Centro. Pra eu sair do Centro às seis horas para estar lá seis e meia, é inviável, então, pensei: "vou fazer enfermagem mesmo". Comecei fazer enfermagem. Gosto muito. É uma profissão que eu admiro demais. Às vezes tem aquelas famosas brigas, que todo mundo fala, entre enfermeiro e técnico, um fala mal do outro, mas eu acho que vai de cada um, do comportamento. Penso que se você está num grupo e você não fala mal do outro, automaticamente você não da liberdade do outro vim falar mal do outro para você. Aqui onde trabalho, meu gerente perguntou: "você tem problema aqui na Faculdade, com alguém?" Eu disse "olha eu chego aqui e não tenho problema com o porteiro, não tenho problema com as meninas do setor da secretaria, não tenho problema com ninguém, do $1^{\circ}$ ao $14^{\circ}$ andar, de fato eu não tenho mesmo". Ele disse "é que vou transferir você para outra unidade". Eu falei "ah, pra mim tudo bem". Não tem esse negócio de se dar bem com um, não se dá com o outro. Às vezes pode não bater os ideais, mas um bom dia/boa tarde, oi minha linda/meu querido; acho que às vezes muda aquela coisa.

No momento da escolha pela faculdade de enfermagem, foi difícil, porque a gente sendo mulher chegar para o marido e falar que vai estudar e dizer: "Vou ser enfermeira", tem aquela coisa do mal visto, infelizmente tem, não é conversa fiada, porque tem mesmo. No sentido da pornografia. Por conta de meia dúzia. A gente sabe que todo hospital tem a boa enfermeira que leva a coisa a sério, se porta como tal, se veste como tal. Como também tem aquela enfermeira que gosta de se insinuar que gosta sempre de levar o crachá de enfermeira para o outro lado. Se a mulher é casada e diz que quer ser enfermeira, a pessoa é nova e fala que quer ser enfermeira, de imediato, dependendo do pai, dos irmãos, dos amigos; sempre vão olhar de um jeito meio estranho, por conta das outras pessoas. Pelo comportamento de outras, desvirtua. Tentando jogar areia na sua sopa. E comigo não foi diferente. Para mim, esfregar com alguém não precisa ser enfermeira. Tem fantasia, eu compro uma. Mas eu não levei em consideração, era um sonho meu e briguei muito.

Meu filho mais velho tem 28, a mais nova tem 10. Falei pra eles: "vocês estão grandes, criados, gordinhos, vocês não tem defeito físico, tem o sonho de vocês todo pela frente". Eu não sei se vou morrer amanhã, mas quero morrer com meu diploma na mão. Se eu não conseguir trabalhar na área, tudo bem, eu sou 
sossegada quanto a isso. Eu quero meu sonho, eu acho que eu tenho direito de sonhar o meu sonho (chorou nesse momento), por isso eu to me separando. Não é fácil, mas bola pra frente. Marido não é parente, magoa, mas beleza! Vou dar muita injeção na bunda dele, a hora que ele estiver precisando estamos aí, a gente não pode ter acepção de pessoas. Às vezes, a gente aprende a duras penas. De repente, lá na frente ele entenda que eu vim pra trabalhar, que vim pra tentar somar, não pra tirar o foco (continuou emocionada). Fico com muita raiva quando ouço alguém falar da enfermagem. Médico não, porque é uma raça fechada. Eles criaram uma redoma, um bloqueio. Já andei em hospital pra caramba como paciente, tive meus filhos e cada um praticamente nasceu em um hospital diferente e nunca vi um médico falar mal do outro, por mais errado que tivesse. Mas, enfermeiro, gente, é impressionante! Eu acho uma vergonha um colega dar as costas e outro falar: "ta vendo, fulano não faz nada" ou "fulano não gosta de fulano". Eles mesmos não percebem que tem esse bloqueio. Tinha que ter aquele negócio: "o que acontece em Vegas, morre em Vegas". O hospital tinha que usar esse lema. Pode se matar com um colega dentro do quartinho. Fechou a porta, cada um lavo o rosto, faz curativo. "Tá tudo bem?". "Tá tudo bem”. "Aconteceu alguma coisa?" "Não. Imagina. A gente estava ali discutindo a relação, mas tá tudo bem". Porque pronto, morreu ali. Resolveu, resolveu, se não resolveu volta ali noutro plantão e se quebra de novo até resolver sua situação, mas não precisa sair falando para os outros. Acho que é falta de respeito por parte dos próprios profissionais. Já começa na sala de aula. Você vê um querendo puxar o tapete do outro, porque não quis fazer um trabalho ou porque não quis participar de um seminário ou porque um fez mais que o outro. Acho isso desnecessário esse tipo de comportamento dentro da área de enfermagem, porque aonde você vai, tem enfermeiro. Os enfermeiros esquecem que também serão pacientes e para o enfermeiro mais velho, aquele mais novo que ele está maltratando ou que ele ta tentando punir ele, vai cuidar dele lá na frente. Ele tem que ter muita sorte da cabeça do novo não ser como a dele. Pra não sofrer, porque tem a lei do retorno. Meus filhos sempre me deram muito apoio até hoje. Eu chego em casa e falo: "Oh, essa semana é de prova, de trabalho". Eles procuram respeitar na questão do barulho, às vezes facilitam, sempre me ajudam muito. Graças a Deus sou uma pessoa privilegiada. Tenho meus sete filhos, chego em casa, no fim de semana eu não faço nada. Sento, meu filho vem, tira meu tênis, o outro pega a toalha. Vou para o banho, quando volto, tem café, leva café na cama. Vou jantar, 
perguntam: "Mãe você quer ovo queimadinho, né?". Levam-me copo d'água. "Quer mais café?". "Tá com a perna doendo"? "Quer massagem?" aí vem um e faz massagem. Acho que não tem nada melhor que isso.

Queria ser mais nova, para esperar mais coisas. Vou fazer 50 anos, mas minha alma é de 15 (risos). Gosto de estar com os jovens. Se tô na igreja, estou com os jovens. Se tô num barzinho, tô com os jovens. Trabalho com idoso, mas para eu estar na ativa, gosto de estar com os jovens, conversar, brincar, trocar ideia, aconselhar. Hoje em dia eu vejo os jovens levarem a vida e eu digo: "Não entendo vocês. Na minha época eu tinha menos conhecimento e os riscos sempre foram os mesmos e a gente se cuidava mais. Vocês têm internet. Vai num posto de saúde, tem camisinha lá, pega quantas vocês querem. Pede um anticoncepcional, marca um ginecologista rapidinho. Não deu certo com um, troca”. Há mil coisas pra não engravidar. Se engravidar, tudo bem e se fica doente? Pega um doença? A filha da minha amiga de 9 anos, pegou sífilis, ficou com medo de cuidar, foi agravando e perdeu o útero. Agora tá noiva, o cara quer ter filho e ela não sabe como falar pra ele porque não pode ter filhos. Eu quero trabalhar com idoso, mas eu também gostaria de trabalhar em posto de saúde, pra lidar com os jovens, na questão da prevenção. As amigas e amigos dos meus filhos contam coisas pra mim que não têm coragem de contar pra mãe. Atraso da menstruação ou se estão com corrimento. Eles dizem: "posso trocar ideia com você?" "Posso ir à sua casa?". Eles nem falam pra eu não contar pra ninguém, porque eles sabem que eu não conto. Eles confiam em mim. Quero usar dessa confiança, mesmo eu ainda não sendo enfermeira, pra quando eu for enfermeira, eles aumentarem a confiança em mim.

Espero que a profissão de enfermagem melhore mais, não somente na questão de conhecimento. Sei que o bom enfermeiro tem que estar todo dia buscando conhecimento, porque cada segundo muda alguma coisa e se ele não correr atrás do conhecimento ele fica para traz. Eu queria que crescesse mais no sentido de tratar as pessoas. Ainda tem aquela coisa de, como vou dizer, descontar... assim, de fato que eles deixassem o problema pra fora. Chegasse na porta do hospital e deixasse: "Eu não tenho problema, não tenho marido, não tenho filho". Que a família de fato desses profissionais fosse de fato aquela pessoa que ele fosse cuidar. Que tivesse esse crescimento interior mesmo. Aquela coisa de cuidar do outro do mesmo jeito que se cuida de um filho. Porque é fácil cuidar de uma pessoa cheirosa, que toma banho, fazer o exame físico, e pegar uma pessoa que tá 
lá no meio da rua todo vomitado, evacuado, sujo, cheio de piolho, cheio de ferida. A gente sabe que o tratamento é diferente. Tem muitas pessoas boas que se esforçam pra fazer essa diferença. Tem gente que não usa nem luva, porque faz de coração. Às vezes esquece. O carinho é tanto em ajudar, que esquece de pôr uma luva. $\mathrm{O}$ outro sempre em alerta, tá sempre com uma luva, que é aquele do coração duro. Tudo bem que tudo é técnica, mas eu levo para o outro lado. Aquele que sempre tá com uma luva, mesmo que ele vai só tirar uma roupa, que não tem como pegar uma doença. Ele põe a luva não somente pra proteger, mas por causa daquela questão humana de não tocar no outro. Eu pude ver isso quando eu tava na casa de repouso e eu cuidava de uma senhora que tinha uma escara no cóccix e era muito funda e a gente cuidava para não piorar. Eu trabalhava de noite e a outra técnica de dia. $\mathrm{O}$ médico tinha dado dois anos para fechar a escara, mas em oito meses ela estava praticamente fechada, a gente não deixava molhar, mudava de posição, sempre cuidando. Veio uma enfermeira do plano da paciente com um médico para passar medicação na escara. Eu coloquei a luva, tirei o curativo. Por conta da medicação, sai secreção. Ela olhou de lado e eu disse: "deu nojinho?" ela falou: "como?" Eu disse: "ta com nojo, por favor, pode sair", ela disse: "Não, não é isso. Eu sou enfermeira”. Eu falei: "Você pode até ser enfermeira, só crachá”. Eu não tenho papas na língua, tem certas coisas que não admito. Não que eu seja uma pessoa que não respeite a patente, que tenha, digamos, uma patente maior que é minha, é que certas atitudes não descem. Quando a gente é novo a gente ainda aguenta. Quando a gente passa dos quarenta a gente pode se dar o luxo de falar coisas, graças a Deus! Eu sei que posso falar que ninguém vai falar nada "ta velha mesmo" (risos). Essa é a vantagem de ficar velha, que a gente fala o que ninguém tem coragem. Eu fico brava de ver um médico cuidando de um paciente com as pontas do dedo. Poxa, não cuida! Vai lá cuidar de uma pessoa mais cheirosa ou não cuida de ninguém. Esse tipo de atitude do profissional da área da saúde é o que mais machuca os outros. Não é nem descaso, é a falta de humanização. O enfermeiro nem tanto, porque no geral, ele fica mais no lado administrativo, a não ser que aconteça uma ocorrência e ele tenha que fazer procedimentos que só cabe a ele mesmo, tem coisa que não da pra ele fugir. Mas os técnicos auxiliares que atendem os pacientes "Ah o fulana; aquele velho; aquela mulher sem braço do 380". Essas coisas que matam, tipo de atitude. 
No futuro, para a profissão de enfermagem, acredito que precisar de postura. Existem diferentes posturas. Tem postura que você tem em qualquer lugar, do respeito, da solidariedade, tratar as pessoas com carinho. Você brinca, ri, porque todo mundo sabe que você esta fazendo tudo dentro do respeito. Ninguém invade essa barreira. Você pode estar em qualquer hospital, desde entrada até o ultimo andar. Você pode brincar com o porteiro, conversar com o faxineiro, seja homem ou mulher. Porque todo mundo vai saber que tudo aquilo que você fala é com respeito. Tem aquela falsa postura, que a pessoa é dura, é seca, é rude, é seria, fecha a cara pra todo mundo, destrata; esse tipo de postura eu não quero para mim eu não sou assim então eu não me vejo assim. Gosto de conversar, brincar.

Trabalho na área administrativa, e como meu estágio está muito longe, eu não quero perder o foco, que é cuidar, por isso dou plantão na casa de repouso. É cansativo? É cansativo. Lucro eu tenho? Todo mundo sabe que eu não tenho lucro. Cada plantão que eu vou dar é pra cobrir uma condução, cobrir a mistura do fim de semana. Não adianta você dizer: "vou me matar para comprar um Citroen no final do ano". Posso até comprar, mas e o seguro, a manutenção? Não quero me afastar no sentido do cuidado.

No futuro me vejo formada. Não vou parar, quero fazer uma pós na área de geriatria, vou montar uma casa de repouso. Em todos lugares que passei, fiz muita amizade. Também quero dar aula, lidar com os jovens. Quando fiz o técnico de enfermagem, meus colegas disseram que a área da pediatria eu ia levar com os pés nas costas, com sete filhos. Porque tem coisa que a gente sabe como profissional e como mãe. Eu me prevaleço nesse sentido. Aprendi muito com os enfermeiros com os técnicos. Quando meus filhos eram pequenos, ficavam internados, quebravam braço, eram atropelados; eles são terríveis. Aprendi muita coisa, mesmo antes de eu trabalhar na área, tinha coisa que eu sabia de tanto ver, de estar na lida, vendo o pessoal fazer.

Quando fiquei internada, teve muita gente que cuidou bem de mim. Mas tive outros que não tiveram compreensão. Às vezes a pessoa julga a outra. Um caso que aconteceu comigo quando eu era nova, eu engravidei e tive um aborto, quando cheguei no hospital, tive que ficar internada e uma das enfermeiras falou: "deixa essa daí, não precisa ficar dando muita atenção, com certeza esse aborto foi provocado". Eu não tinha filhos. Essa pessoa me julgou, ela nem sabia o que tava acontecendo, me pré-julgou e me condenou, quer dizer, eu não merecia o cuidado. 
Mesmo que eu tivesse feito o que ela tinha dito que eu fiz, ela não estava ali pra me julgar, ela estava ali pra cuidar de mim. Essas coisas, eu como paciente não quero fazer para os outros, porque sei que dói a gente estar na dependência de alguém. Não precisa ninguém julgar o outro, a nossa consciência já acusa a gente. A gente precisa de alguém pra dar uma palavra amiga; "ah, porque é bandido". Eu queria ver se fosse seu filho. É difícil, é difícil. Sei lá, você ter na família alguém que foi violentada e você ter que cuidar daquele infeliz. Não deve ser fácil, mas eu acho que no nosso trabalho a gente faz aquele papel, a gente tem que fazer a palavra que ta na bíblia, não pode ter acepção de pessoa. Você vai ter que cuidar daquela pessoa, não importa quem vai chegar naquele hospital, é bandido, tomou um tiro, violentou, estrupou. Não interessa, caiu na sua mão, é uma vida, você não deu vida pra ele, você não é Deus. Acho que falta, cada um dentro da sua religião, um pouco de Deus, de Jeová, de Ala, não sei, cada um tem dentro de sua religião um Criador. Acho que falta muito desse Criador dentro da pessoa, porque julgar é fácil, mas quando você tá do outro lado da moeda, ai você vê o poder que tem seu julgamento, quando você é julgado, aí você não segura a onda, aí você quer se matar, quer fazer um monte de coisa. Coisa mais horrível é você ser julgado ainda mais ser julgado por uma coisa que você não fez e ser julgado por uma pessoa que está cuidando de você. Toda a hora vai abrir a porta, às vezes a pessoa faz aquele comentário: "A gente tem que trabalhar e ganha pouco, pra isso, pra cuidar de gente assim, tinha mais é que morrer mesmo". E outros comentários mais pesados. Acho que o enfermeiro ou o técnico ou o auxiliar, tem que aprender a ser humano mesmo. Acho que só devia dar o Coren, tipo como carta de motorista, aquela coisa bem provisória pra ver se a pessoa está realmente apta para aquilo, porque ser feito nas coxas não dá.

Tive meus filhos que ficaram doentes, graças a Deus, foram cuidados por gente boa. Um dos meus filhos saiu do caminho, mas graças a Deus já voltou. Foi preso. Quando eu cheguei na delegacia eu não perguntei se ele tava bem eu perguntei: "ele matou alguém, ele machucou alguém?". Sempre falei para os meus filhos: "a vida é uma coisa muito preciosa, ninguém tem o direito de tirar a vida do outro, não importa quem seja”. Eu ia ficar muito mais triste sabendo que meu filho matou, mutilou uma pessoa. Fiquei triste? Fiquei, mas fiquei aliviada. Acho que tudo o que a gente faz nessa vida, tem um retorno. Eu sempre procuro falar isso para eles e foi de tanto falar, que graças a Deus, ele ouviu, tarde, mas ouviu. Ficou preso, 
longe de mim, ficou doente. Eu tinha que acreditar em que tava cuidando dele, acreditar que lá dentro tinha um profissional que tinha minha cabeça. Tinha que acreditar que onde quer que ele estivesse ou pra onde ele fosse levado, ia ter um profissional que teria minha cabeça, senão, o que ia ser dele? "Ah um mundano, um bandido. Ah, esses carros de polícia, a gente tem que parar de atender os outros pra atender esse marginal" (se referindo aos profissionais da saúde). Só que esquece. E se eu tivesse trabalhando, esse marginal podia ser meu filho, podia ser o seu. Uma hora você pode tá trabalhando lá, aí seu filho chega lá baleado. A polícia atirou nele, porque ele tava roubando, você vai dizer a mesma coisa? "Deixa morrer. Enfia o dedo dentro do buraco dentro da bala pra ele morrer mais rápido, dar uma hemorragia pra ele morrer mais rápido". Você vai falar? Igual a gente cansa de ouvir por ai, porque eu ouvi, quando eu fiz estágio, eu ouvi. PS do Mandaqui lá o que mais chega é isso daí, Ouvi isso do enfermeiro e do médico. Você fica olhando e fala: "Putz, já pensou se uma hora dessas chega um filho deles, um irmão, um primo, um sobrinho baleado, a polícia arrastando do jeito que arrasta". Fala: "Ah, o lixo aqui, o tranqueira aqui tava roubando. Eu peguei ele estuprando uma menina". Você ia enfiar o dedo no buraco? Falar: "Ah deixa sofrer, deixa sangrar, daqui a pouco a gente vê. A gente vai ver as pessoas decentes, depois a gente vê se esse lixo sobreviveu. Da uns quarenta minutos se ele sobreviver a gente cuida dele".

Uma vez tiveram que levar meu filho para o hospital quando ele passou mal. Um enfermeiro deu remédio pra ele levar pra cadeia, deu uma atenção. Se não tivesse dado? Meu sonho ia morrer por causa de um sujeito desse que não cuidou bem do meu filho, que não tinha uma cabeça igual a minha. Eu ia falar: "Pra que eu quero ser enfermeiro. Pra isso? Não quero". Mudar o comportamento dos outros eu sei que eu não vou mudar. Não interessa, eu quero fazer diferença. Sei que sou uma boa amiga. Cem por cento sei que a gente não vai ser. Nem Jesus agradou todo mundo. A gente não agrada gregos e troianos, mas acredito que boa parte dos gregos eu sei que agrado. Quero fazer essa diferença na área da saúde. Quero que me vejam assim: "Olha, ali tem um velhinha, naquele posto tem uma velhinha meio doidinha, mas vai lá, conversa com ela, tenho certeza que ela vai te dar uma força, vai dar um jeitinho pra você passar lá". Eu quero fazer essa diferença. Sei que não vou ganhar mais por causa disso, mas sei que o dia em que eu morrer, terei um enterro de Presidente, terá muita gente. Sei que vai bastante gente pra jogar pedra no meu caixão (risos). Mas sei também que vai muita gente pra jogar aquela 
terrinha, florzinha, chorar, bater palma, cantar o Timão, o hino do Corinthians para mim (risos). Às vezes a pessoa morre e a gente vê um monte de gente chorando de alegria (risos). Quero fazer essa diferença como profissional. 


\section{Participante 3}

Enfermeiro para mim é um área muito ampla, porque além de você cuidar, você zelar pela vida de um paciente, você salva. Por mais que o paciente fale que o médico salvou a vida dele. Quem salva, pra mim, é o enfermeiro. Quem tá diariamente, quem o vê sofrer, quem o vê lutar, é o enfermeiro. Pra mim é isso, é um conceito de vida. É você gostar de simplesmente ajudar.

Desde pequena me interessei por sangue, por osso quebrado, por doença e tudo mais. Comecei o auxiliar com dezesseis anos, mas abandonei o curso depois que tive um trauma no estágio. Perdi uma paciente que eu me apeguei muito a ela. Ela sofria demais, demais. Quando ela faleceu, infelizmente eu não estava no hospital, porém, na noite anterior ela pediu para que eu ficasse, porque ela não tinha ninguém. Saí do plantão de estágio, liguei para os meus pais e falei que ia passar a noite inteira com ela. Fiquei a noite com ela e ela me disse que sabia que no dia seguinte ia morrer. Abandonei o curso faltando um mês para concluir. Não aguentei, fiquei muito mal, muito mal mesmo e abandonei. No ano seguinte retomei tudo de novo, comecei do zero, comecei mais forte. Todo mundo fala que gosta da área, mas é muito difícil suportar isso. Você vê o sofrimento da pessoa, por mais que você entenda, você chega em casa, coloca a cabeça no travesseiro, você lembra de tudo que passou ali.

Conclui o auxiliar e fiz o técnico de enfermagem. Passei por outra coisa. Fui dar banho em um paciente psiquiátrico. Até hoje eu tenho trauma em dar banho em paciente. Todo mundo me falou que ele não gostava de tomar banho, mas ele parecia ser muito dócil e ele era enorme. Simplesmente falei: "Vamos tomar banho". Ele foi comigo e disse: "Mas não quero tomar banho", eu falei: "Vamos tomar banho. Banho é bom, é gostoso!" E a gente foi para o banheiro. Quando ele começou a tirar a roupa, colocou as mãos no meu pescoço e me enfiou debaixo do chuveiro. Ele me deu um banho (suspirou sorrindo). Depois disso fiquei traumatizada, fui embora na mesma hora, deixei tudo para traz. Não me machuquei, mas fiquei com as marcas dos dedos dele. Mexeu mais com o psicológico, porque a reação foi inigualável, ele mudou do nada. A gente sabia que paciente psiquiátrico era assim, mas ele parecia se tão bom, tão bonzinho que a gente não imaginava que isso ia acontecer. $E$ eu gritava e ninguém me escutava. Eu tava sozinha com ele. Quando viram que estava demorando demais no banho que foram ver eu tava molhada no chão do banheiro. 
Fui embora, deixei, mas não parei. Eu já tinha parado uma vez, e decidi não parar. Decidi continuar.

Tive dois exemplos de professoras do auxiliar de enfermagem que até hoje eu carrego comigo. São pessoas maravilhosas. Vi elas socorrendo pacientes caídos na rua. Feridos de acidente de carro. Você vê e fica abismado e você simplesmente pensa "eu quero ser que nem ela". Eu quero ter, não um sangue frio, mas você saber lidar com a situação e conseguir cuidar. Você vê uma cena horrível a pessoa presa e ao invés de você perguntar se ela tá com dor, você simplesmente parar, olhar e cuidar, dar os primeiros atendimentos sem nada. Pra mim enfermeiro é como se fosse um anjo sem asa. É o que realmente são.

Desde o início eu sempre tive amigos da área, por isso eu pensei comigo que eu não iriar fazer enfermagem. Eu queria fazer fisioterapia, queria fazer gastronomia, menos enfermagem, porque eu conhecia um monte de enfermeiro, um monte de auxiliar e a gente se encontrava e só falava disso, só falava de paciente. Eu falei: "Gente, eu preciso de outra vida, não da. Será que eu vou aguentar até o final da minha só falar disso?" Porém, acho que é destino a gente não escolhe a nossa profissão, basicamente, ela escolhe a gente. Eu vim na faculdade, escolhi enfermagem. Para minha mãe é um orgulho. O sonho dela era que me tornasse enfermeira. Porém, é só metade do sonho dela que eu vou realizar, porque ela quer que eu seja obstetra e eu não vou ser. Mas fora isso, todo mundo apoia muito. Por mais que alguns falem: "Ah, isso não é vida! Plantão de doze horas! Vira muito tempo. Você não tem tempo pra sua família! Você vai querer uma família no futuro?". Eu acho que o que importa é o que a gente pensa. Lá na frente a gente resolve essas questões. Agora o que importa é o que eu quero e o que eu quero é me tornar enfermeira.

Lembro que quando eu tava com 16 anos, estava cursando o ensino médio. Apareceu uma oportunidade de ganhar um curso na escola. Tinha que optar por 4 profissões. Coloquei fisioterapia, gastronomia, radiologia e por último enfermagem. Fui a $4^{a}$ sorteada da escola inteira e caiu enfermagem para mim. Você poderia não escolher aquele curso, porém talvez você poderia não conseguir o outro. Então eu fui em frente, consegui. Corri muito atrás. Para meu pai era um orgulho. Ele trabalhava à noite e tinha que me levar para a escola de manhã, porque eu chegava cansada. Isso era na época do auxiliar, eu fazia estágio em Osasco, eu moro na Zona Norte. Meu pai tinha que me pegar em Osasco. Era um cansaço extremo, 
extremo, mas ele sempre falou pra mim: "um dia tudo vai valer a pena. Você sofre hoje para amanhã você dar risada". É isso que vale pra mim. Pra mim, nada nunca foi fácil, sempre tinha um empecilho e eu tenho minha frase que é meu objetivo de vida "que nada é fácil, que se está fácil é que ta errado". A primeira semana de estudo aqui na faculdade já está pesada. A gente já vê que vai ser uma coisa muito forte. Mas é isso que a gente quer, e é isso que eu vou correr atrás.

$\mathrm{Na}$ época da escolha pela enfermagem eu tinha um namorado que encarou super bem, apoiou. Falou que eu devia seguir. Falou que era uma profissão difícil. Falou que a mãe dele era enfermeira e que ela o deixou muitas noites em casa sozinho, porque tinha que trabalhar, mas que ele tem orgulho da mãe. $E$ hoje eu sei que ele tem orgulho da mãe dele.

Espero que a profissão de enfermagem melhore muito, porque eu já vi coisas, não vou dizer horríveis, mas coisas do tipo que o enfermeiro não sabia passar uma sonda de demora e um auxiliar sabia. O auxiliar no primeiro estágio sabia passar sonda. Sei que existem muitos enfermeiros bons. Mas como minha professora fala: "Não estou aqui para formar enfermeiros bons, e sim excelentes! Porque vão lidar com vidas". Se fosse a nossa mãe no hospital a gente cuidaria muito melhor.

Espero que os enfermeiros sejam mais reconhecidos, porque não são. É como se fosse uma linha de tiro e o enfermeiro tá no meio entre o paciente e médico, e o enfermeiro sempre segura a carga.

Vejo-me daqui 7/8 anos, quem sabe, formada. Com pós em ortopedia. Pretendo me alistar na Marinha ou na Aeronáutica. É um sonho. São dois sonhos que eu posso ligar, que é me alistar, e me tornar enfermeira. Isso pra mim já é um privilégio enorme. É uma coisa que eu quero pra vida, que eu sei que se eu conquistar vou ter conseguido tudo o que realmente queria. Ai só vai faltar os trigêmeos, só (risos). Vejo-me com um futuro bom. Sempre fui preparada para as coisas ruins. Você pode sair na rua, pode ser atropelada, pode acontecer alguma coisa de ruim com você, mas eu sempre penso que pode acontecer alguma coisa boa também. 


\section{Participante 4}

Ser enfermeiro é basicamente cuidar. Você tem que amar a profissão. Não adianta você fazer e não gostar, por dinheiro. Sei que enfermagem não dá dinheiro, você tem que amar. É cuidar do próximo.

Procurei a enfermagem para ser um novo pesquisador da doença que tenho.

Em 2003, namorei uma menina no colégio. Ela fazia enfermagem em uma faculdade, no Albert Einstein. Nosso nível, como posso falar, era diferente. No caso, eu era o garoto pobre e ela a garota rica. Eu era novo, tinha 14 anos e ela tinha 21 e tava terminando a faculdade. Eu a ajudava nos trabalhos, porque sempre gostei de pesquisar. Como a gente não tinha tempo junto, a matéria que ela tinha necessidade de fazer, eu fazia para ela. Comecei pegar gosto pela enfermagem, comecei a gostar. Fiz o auxiliar, não peguei meu COREN ainda porque meu nome estava errado. Mas eu não quero seguir agora no auxiliar, quero focar mais nos estudos da faculdade.

Aos 14 anos fiz teatro e dança. Tudo o que envolve a parte artística. Quando decidi estuda enfermagem, minha mãe me apoiou. Qualquer coisa que eu vou fazer, ela apoia, porque desde criança tinha o interesse de fazer enfermagem, mas não tinha coragem, porque me escondia um pouquinho.

Em 2010, minha mãe teve um AVC. Eu estava no hospital. Vi o enfermeiro e o médico consultando como se fosse uma pessoa qualquer. Ele não mostrava aquele carinho pelo paciente, não mostrava uma paciência pra conversar. Então pensei: "Vou entrar nessa área e vou mudar, não vou fazer igual a eles. Quero saber como está o paciente, como está a família". Não adianta cuidar do paciente e não cuidar da família, porque a família tem que ajudar e se não instruirmos a família a lidar com o paciente, então será em vão o tratamento do paciente. Em seguida, falei pra minha mãe: “Quero ser enfermeiro", não falei que queria ser médico, não é meu ponto de vista agora. Ela começou chorar. O médico viu e deu um sorriso sarcástico, do tipo "Vai ser mais um". Minha mãe disse: "você tá na área de teatro". Eu falei: "Não mãe, eu tô vendo a senhora aqui, eu tô vendo o que as pessoas estão passando". A partir daí comecei ter outra visão da enfermagem querendo estar mais presente nela. Tanto que eu gosto de hospital. Às vezes quando vou ao hospital pra fazer alguma coisa, consigo um jeito de escapar e entrar em alguns leitos pra visitar, mas só para 
olhar, oro pela pessoa. Vou passando em cada lugar que dá para eu passar, mas tudo escondido.

Meu amigo não apoia essa minha decisão pela enfermagem, ele acha impossível eu ficar nessa área por eu estar doente. Sou portador do vírus do HIV, então ele acha que pode ter complicações no futuro. Tenho somente dois amigos fieis, que sabem sobre minha doença. Eles têm medo, me apoiam, mas têm muito medo de eu sofrer preconceito dependendo da área que eu for seguir e ter uma decepção no futuro e não conseguir emprego, não conseguir me estabilizar nessa área . Eles acham que eu posso me frustrar no decorrer da faculdade. Meu irmão não opina em nada que do eu faço, mas dois amigos meus têm a mesma concepção, acham que posso me complicar futuramente. Meu pai não mora em casa, mesmo que ele morasse também não opina, a gente não tem dialogo entre pai e filho. As minhas duas ex-sogras, uma da menina que eu namorei e a outra do menino que namorei - hoje eu sou gay. Ambas me apoiaram. Uma delas me apoiou, pois teve câncer e, agora, por ser portadora do vírus do HIV recentemente. Quando ela ficou sabendo ela disse: "segue que essa profissão é linda! Quem sabe você não vai achar a cura também?"

Muitos dizem que vou ser bem sucedido, vou ganhar muito dinheiro, mas não, eu não vejo por esse lado, não importa o valor que eu for ganhar. Cada sorriso que eu conseguir tirar de um paciente, para mim, será gratificante.

Quero seguir na área da saúde, mas pode ser que eu não fique como enfermeiro, como pesquisador, mas simplesmente como o "Clau" (referindo ao personagem artístico), por eu já ter feito teatro, eu tenho técnicas para usar tanto em adultos quanto em crianças, pra trabalhar nessa parte psicológica delas, no voluntário. Tem que ter uma pessoa pra fazer um sorriso. Isso pra mim já é gratificante. Não é uma questão de valores, não. E sim pelo sorriso que vou ganhar.

Sempre gostei da área da saúde, mas no começo eu fiquei em dúvida no que realmente queria pra mim. Ou eu estava envolvido na área da saúde por conta de eu gostar da minha ex, ou porque realmente eu estava abrindo um leque de informações, que estavam me possibilitando aceitar essa área pra mim, e agora eu não sei (risos).

No futuro, penso fazer pós em psiquiatria. Não sei o nome certo da outra pós, mas quero estudar para cuidar de pessoas portadoras do vírus do HIV. Não quero trabalhar em hospital. Quero ter minha ONG. Tive oportunidade de trabalhar em uma 
ONG e ter uma parceria. Quero ajudar principalmente as pessoas portadoras do HIV e também os pais e os amigos. Para ajudar a lidar com o problema. Os maiores portadores do vírus são os gays. Já sofrem preconceito por serem gay e se escondem na doença achando que não vão mais viver e é o contrário, eles vão poder viver, eles têm uma vida normal. E é aí que entra a parte da psicologia e psiquiatria. Muitos acabam tendo problema mental e acabam cometendo suicídio. Eu quero ter essa ONG pra ajudar essas pessoas, principalmente as famílias deles. Posso trabalhar em hospital, mas a princípio quero ter minha ONG.

Em junho de 2014, descobri que era soropositovo. Nessa época estava fazendo o auxiliar de enfermagem. Foi um choque. A primeira coisa que eu pensei foi em suicídio, eu queria me matar, eu não aceitava isso pra mim. Através dos meus dois amigos, do tratamento, tive outra visão. Não queria mais viver. E não é bem assim, a gente vive mais do que uma pessoa "normal", porque a gente se preocupa mais em tomar remédio, se cuidar. A gente consegue ter uma vida normal. 


\section{Participante 5}

Quero ser enfermeira para salvar vidas. Quero fazer pós em obstétrica porque gosto muito da vida. Acho muito lindo, até mesmo as pessoas que sofrem acidente você vê ela debilitada, e depois você ela vê bem. Isso é muito gratificante. Ser enfermeiro para mim é ter amor à vida. Amar a profissão. Ter amor ao próximo. Você querer ver o bem do próximo.

Minha mãe parou de estudar, depois voltou. Ela sempre gostou da área da saúde. Ela começou a falar como era. Comecei a namorar, minha sogra era enfermeira. Minha mãe terminou o colegial e foi fazer o curso de auxiliar e técnico de enfermagem. Nesse período ela se separou. Eu tinha 15 anos na época. Como ela trabalhava e ia direto para o curso, eu ajudava ela a fazer os trabalhos. Ela chegava e dizia: "Pesquisa alguma coisa pra mim, quando chegar eu leio". Fui me interessando a partir daí. Também meu sogro chegava da ambulância com aquela bota, eu achava muito engraçado aqueles acessórios na bota. Fui pegando amor a partir daí. Meu namorado entrou na vida errada, terminei o namoro. Depois de 8 meses que não estávamos mais juntos, ele levou um tiro na cabeça. Ficou entra a vida e a morte. Cheguei vê-lo no hospital. Ele foi para o hospital público. Tinha todos os aparelhos, mas não tinha médico para operar ele. O tiro ultrapassou a cabeça, entrou de um lado e saiu do outro. O médico falou que era pra ela - minha sogra assinar o óbito, mas ela disse: "Não. Eu quero ver vocês animarem ele na minha frente". Reanimaram ele e ele voltou com 1\% de vida. Foi transferido e começou daí, desse $1 \%$. Fez várias cirurgias. Depois disso, ele foi pra fundação, porque ele era menor ainda. Ficou uma semana. Por ela ser enfermeira, liberaram ele pra ir pra casa, pra ela cuidar dele, porque ele não enxergava direito. Ele não comia. Até o remédio tinha que amassar. Minha sogra trabalhava em um hospital. Como ela não ficava o período todo em casa, eu tinha que ajudá-la. Ele veio para casa parecendo...sei lá, ele não andava, não comia, nem falava direito. Foi muito difícil. Foi um ano mais ou menos pra recuperar. Eu fui acompanhado isso, ajudando. Quando ele andou de novo, parecia um bebê. Foi daí que fui pegando amor pela área da saúde. Como eu o levava para a fisioterapia, fui conhecendo os casos. Pensei que: "É isso que eu quero pra mim". Quero entrar para essa área. Pensei em fazer fisioterapia. Minha mãe disse: "Tem certeza?". Eu disse: "Tô em dúvida entre fisioterapia e enfermagem". Minha mãe disse: "Não faz enfermagem por causa de 
mim. Não faz algo só porque eu quero". Na época minha mãe tinha se formado como auxiliar e técnico de enfermagem.

Lembro outro acontecimento quando minha bisavó morreu. Ela tava doente, com depressão, mas faleceu de infarto. Eu ficava no hospital com ela. Eu convivia como enfermeiros. Ela foi pra casa e não queria comer, nada. Tinha que ter muita paciência. Ela era só por Deus (risos). Minha mãe me ensinava a verificar pressão, os batimentos. Um dia meu tio chegou em casa dizendo que minha bisavó tava passando mal. Quando cheguei lá ela tava deitada com uma parte do corpo no chão e outra na cama. Eu escorreguei no "xixi" dela. Eu falei: "Com certeza foi infarto. Ela morreu". Meu tio "Como você sabe que ela morreu? Faz alguma coisa!". Eu falei: "Não tem o que fazer. Ela já fez ate xixi". Liguei pra minha mãe e fui ver os batimentos, mas como ela era muito velhinha eu não tava conseguindo sentir. Minha mãe pediu para eu colocar um espelho na boca dela e eu via que não havia respiração. Chamei o SAMU, mas até ele vir, chamei uma vizinha que é enfermeira bem antiga, não era nem enfermeira antes, era atendente. Ela foi e disse que minha avó havia falecido. O SAMU chegou e tentou reanimar minha vó. Perguntei pra minha mãe: "Reanimar não é bom, por que eles fazem isso se a pessoa não volta? Ela ia morrer de qualquer jeito!" Minha mãe disse: "Mas eles tem que tentar" Dai fui pegando gosto.

Matriculei-me em fisioterapia. Gostei. Fiz o primeiro semestre, só que como eu trabalhava no shopping, tinha que dobrar, das $10 \mathrm{~h}$ às $22 \mathrm{~h}$, eu não estava conseguindo conciliar faculdade e serviço e peguei 4 DPs. Parei a faculdade, porque ficou muito caro, foi para $\mathrm{R} \$ 1300,00$ por mês. Minha mãe falou: "Você vai voltar o ano que vem? Você jura que você vai voltar pra faculdade? Você pode fazer o que você quiser". Eu falei: "ano que vem eu volto". Mas ela ficou muito triste. Eu pensei "sabe de uma coisa, eu vou fazer o auxiliar de enfermagem", mas fiz uma semana do curso, porque não queria pagar um curso, sendo que ia demorar quase 3 anos, e a faculdade são 5 anos. Pensei, então, em cursar a faculdade de enfermagem.

Ao me inscrever nessa faculdade, o site daqui dizia que tinha fisioterapia. Mas descobri que não tinha. Então pensei: "No que eu passar, eu vou, eu gosto dos dois". Passei para enfermagem. Minha mãe até chorou! Ela atua na OASI, cuida de idosos à noite. Meu pai também me apoiou. Ele diz que só quer o meu bem, minha felicidade e me ver formada. Para meus irmãos também ta tudo bem. Tenho um irmão de 7 anos e uma de 17. Minha irmã não gosta da área da saúde, só da área 
da beleza. Ela falou: "Você é doida de ficar em hospital, mas vai, eu ajudo você". Meu irmãozinho disse: "Você vai ser médica, vai dar injeção nas pessoas, igual você né mãe?" (sorriu). Tenho outros irmãos, mas não tenho muito contato. Meus amigos disseram: "Se acontecer alguma coisa comigo eu vou chamar você pra cuidar de mim". Eu disse "eu não sou médica" (risos). Nessa época, quando decidi fazer enfermagem, estava namorando outro rapaz, ele também me apoiou muito. Não tenho ninguém que ficou contra. Todo mundo ficou feliz, porque eles veem o enfermeiro como um missionário do cuidado ao próximo, sendo considerada uma área gratificante.

Comecei pesquisar mais sobre enfermagem. Quando entrei no curso, minha professora pós-graduada em obstetrícia começou a falar sobre a área. Pensei: "É isso o que quero para mim". Acho muito lindo acompanhar gravidez e sendo fisioterapia não ia poder fazer isso. Minha mãe disse: "Então, você faz enfermagem e vai fazer a pós". Eu falei: "Vou, quero fazer porque gosto da parte da vida. É, só isso que eu quero". Minha mãe disse: "É mais você vai ter seu primeiro óbito". Eu disse: "Mas eu quero só a vida" (sorriu). Minha família me apoiou bastante.

Não entrei na enfermagem por dinheiro, quero só fazer o que gosto. Quero cuidar do próximo como se fosse minha mãe. Espero que a enfermagem seja mais reconhecida, já mudou bastante. O reconhecimento seria na diferenciação do enfermeiro, do técnico e do auxiliar. 


\section{Participante 6}

Enfermeiro salva vida. É tudo o que eu queria. Antes não pude estudar, não tinha condições. Meu pai teve muitos filhos. A gente fez o que pôde, não dava pra estudar. Tinha que trabalhar e tivemos que parar de estudar. Logo casei, fui cuidar de casa, família, marido, filho. Sempre tive vontade de fazer enfermagem, minha irmã mais velha fez, ela conseguiu e eu tava ficando pra trás. Minha outra irmã fez e eu não. Os netos vieram, comecei cuidar de netos. Chegou uma hora que o casamento não tava dando certo. Separei-me há três anos. Voltou novamente a vontade de fazer enfermagem. Hoje tenho 52 anos. Fiquei desempregada. Meus filhos estão todos criados e pensei: "não vou ficar a vida toda cuidando de neto, senão vai ser a mesma coisa com filhos. Criei meus filhos, agora vou fazer a mesma coisa? Deixar-me de lado?" Precisei trabalhar, pois meu ex marido não ajuda em nada. Tanto tempo afastada do trabalho, tive que pegar a primeira coisa que tinha na frente, que foi a limpeza. Eu via tanta gente trabalhando e estudando e pensava: "por que não posso?". Eu vou realizar meu sonho. Minha irmã estuda administração em outra unidade e me incentivou. Meu sobrinho também estuda lá. Eu queria fazer, mas não podia pagar. Mas minha irmã disse que pagava pouquinho, que pagava $R \$$ 40,00. Eu disse: "Só isso? Então me da o endereço". Fui à unidade dela, mas enfermagem era nessa unidade, onde estou. Fiz a matrícula e já comecei. Aqui a mensalidade é $R \$ 100,00$.

Minha irmã mais velha se aposentou. Trabalhou mais de 30 anos no Emílio Ribas, ela fez o auxiliar e o técnico de enfermagem. Minha outra irmã fez, mas não estagiou, ela viu que não era aquilo que ela queria, agora ela trabalha no banco há mais de 20 anos. Ela desistiu. Minha outra irmã também começou, quando era chegou a aula prática de injeção, tinha que dar um no outro, aí ela desistiu também.

Quando tive certeza que queria fazer enfermagem, tinha uns 18 anos. Foi quando entrei numa sala que minha irmã cursava o auxiliar de enfermagem, eu acompanhava as aulas, fingia que era aluna, até eles fazerem a lista de chamada. Era em uma igreja que estava oferecendo o curso gratuito, acho que pagava só uma matrícula. Minha irmã estava fazendo porque tinha que fazer alguma coisa, e eu que queria, mas engravidei, casei, aí acabou meu sonho.

Há uns 15 anos minha sogra fez uma cirurgia de pedra na vesícula. Foi pra casa com um dreno. Não sei como, mas entupiu aquele dreno. Ela ficou mal. Foi as 
pressas ao hospital e ficou internada por 6 meses na UTI e quarto. Quando ela ia para o quarto eu ficava com ela. Via as enfermeiras cuidando. Eu falava: "Meu Deus é isso que quero fazer!" Me dava vontade de fazer o que as enfermeiras faziam, eu ficava em cima e : "Por que eu deixei passar?" Achei que era tarde.

Tive uma neta que nasceu de 5 meses e ficou 3 meses no hospital, pegou peso e teve alta. Nasceu com 800 gramas. De vez em quando eu ia lá, mas só podia entrar mãe e pai na UTI. Eu ficava pensando: "Meu Deus, se eu tivesse ali, eu podia entrar. Por que eu deixei passar?" Voltou aquela vontade novamente de fazer enfermagem. Levei-a pra casa e eu que fiz todo o cuidado, remédio, levar nos especialistas. Assim que ela nasceu, teve convulsão, hemorragia na cabeça, nos pulmões, pegou infecção hospitalar, teve duas paradas. Ela foi guerreira e conseguiu vencer tudo isso. Corri com ela. Hoje ela é perfeita. Não ficou com nenhuma sequela. Quando faltava 5 dias pra ela completar um ano, teve que fazer cirurgia do sopro, porque não fechou. O cardiologista tava acompanhando pra ver se os medicamentos que ela tomava iam fechar as cavidades, mas não fechou, teve que fazer a cirurgia. E nos últimos exames dela estava aumentado as cavidades. Fiquei no hospital. E aquela vontade bateu de novo: "Meu Deus, por que eu não fiz enfermagem eu ia ta aqui cuidando, sabendo tudo o que tá acontecendo?!" Então, deu tudo certo, teve alta. Hoje ela esta com 4 anos, tem muita saúde. Fui trabalhar e ela teve que ficar na creche, eu que cuido dela, a mãe dela não quer saber dela. Comecei trabalhar demais, aquele cansaço. Acordo 4 horas da manha e penso: "Meu Deus do céu, por que eu não estudei? Todos da minha época estão formados, quase se aposentado. E eu trabalhando aqui na limpeza. Vou dar a volta por cima".

Meu pai morreu atropelado perto de casa (chorou). Ele teve uma fratura na cabeça, na clavícula e na costela. Foi para o PS. Ele tinha 90 anos. Eu tinha uns 25 anos. No PS subiu escada pra tirar RX. Não sei nem se tinha alguma parte das pernas quebradas. Fizeram ele subir na maca. Depois viram no RX que ele estava com fraturas. Enfaixaram ele tão apertado e o meu irmão que acompanhou ele (chorou). Ele foi muito forte. Ele dizia "Meu filho solta isso daqui porque ta doendo muito" (continuou chorando). Se eu soubesse eu diria ao meu irmão: "Ele ia morrer mesmo, por que você não soltou?" E meu irmão dizia que não podia mexer. Meu pai começou a tossir com muito sangue. Colocaram ele na ambulância e foi transferido ao servidor e foi direto pra UTI. Lá teve morte cerebral. Ficou três dias assim. Os médicos falaram que ele foi muito forte. Isso me abalou e eu nem sei se eu fosse 
uma enfermeira o que ia fazer com meu pai daquele jeito. Eu ia fazer de tudo pra ajudar...ou não teria condições de chegar perto também, ia ficar de longe...nao sei, mas se na época se eu fosse enfermeira ia entender tudo o que tava acontecendo com ele, se tava muito grave, se tinha chance.

Meus filhos estão todos felizes em relação a minha escolha em estudar enfermagem. Minha filha parou a faculdade, meu filho parou também, o outro só terminou o colégio público e não foi adiante. O meu filho do meio chegou a fazer curso preparatório para entrar na policia militar, mas por causa da época das greves dos anos, não sei o que aconteceu, não conseguiu entrar. Meu ex marido me apoiou, mas que não pode me ajudar porque não tem condições. Fomos casados durante 29 anos. Em um final de semana foi aniversário da minha sobrinha e uma das minhas irmãs perguntou porque eu ia fazer enfermagem e disse que duas sobrinhas também iam estudar onde estudo e as chamou e me disse: "Você tem certeza? Vai chegar no final do curso e você não vai conseguir pagar". Eu disse que havia entendido bem como era fora de pagamento, que a gente podia pagar em 20 anos e vai parcelar. Minha irmã perguntou se eu ia ficar a vida inteira pagando. Eu disse: “Ainda não chegou lá. Quando chegar a gente vê como vai fazer". Minha irmã disse que as minhas sobrinhas foram lá e viram que estava muito caro, mas eu disse que ia fazer, já havia feito a matrícula. Minha irmã disse que a mensalidade vai aumentar e eu não vou conseguir pagar. Eu fiquei preocupada, mas fiquei firme.

Espero ser uma boa enfermeira. Quero me dedicar ao trabalho. Fico pensando até que posso me aposentar, mas penso em continuar trabalhando. Tenho vontade de trabalhar em posto de saúde, porque da pra sair mais cedo, tenho mais tempo pra fazer as coisas em casa, porque hospital é mais puxado, mas também qualquer coisa é bem vinda, vou abraçar. Nem todos os enfermeiros gostam do que fazem. Tem muitos que estão ali pelo dinheiro, porque quando minha sogra estava internada teve um dia que fiquei em pânico. Ela tinha que ser aspirada e ela tava ficando sufocada, ela dava sinal pra mim, olhava pra campainha. Apertei a companhia, fiquei esperando, foi me dando um desespero, ela tava ficando escura. Saí e pensei: "O que eu vou fazer? Não posso pôr a mão nela, não posso aspirar. Vou chamar a enfermeira". Fui ao balcão onde estava a chefe. Tava piscando a luz, ela estava escrevendo. Eu pedi por favor pra ela ir ao quarto porque minha sogra estava passando. Ela disse: "Eu já vi”. Eu falei: “Mas ela tá passando mal mesmo". E ela disse que já tinha visto a companhia e era pra eu voltar ao quarto e aguardar. Eu 
falei pra ela: "Vou ficar aqui ta?" Não queria ver ela morrer. Voltei, mas fiquei na ante sala do quarto, onde coloca o avental. Não olhava pra minha sogra. Abri a porta e minha sogra estava piorando. Até que alguém veio bem tranquilo. Acho que é ate assim que tem que ser mesmo, porque eu tava no desespero (risos). Eu não sabia o que fazer, meu desespero. Queria fazer algo, mas não saber o que fazer. Ele entrou, aspirou numa tranquilidade. Como eu queria fazer aquilo que ele tava fazendo, tão simples. Podia aprender e ajudar ela. Tinha que ter uma pessoa vendo aquilo. Uma outra pessoa pra ver o que tava acontecendo. Devia ter mais profissionais, melhorar . Tinha só aquela profissional no balcão, não sei se estava na troca de plantão. Mas eu fiquei chateada. E se aconteceu o pior?

Portanto, acho que devia melhorar a o atendimento ao paciente. 


\section{Participante 7}

Sempre tive uma figura muito distorcida do enfermeiro, como um mandão, um chefão, digamos assim, o vagabundo do hospital. Agora fazendo a faculdade a gente vê por um outro ângulo. Até porque, generalizando, o enfermeiro quando se forma, eu acho que sobe um pouco pra cabeça dele. Parece que o grau de superioridade dele se eleva um pouco, então, ele passa a tratar o auxiliar e o técnico um pouco meio que, como se fosse o faxineiro dele. Eu já sofri muito na mão de enfermeira, de enfermeiro. Eu falava que ia fazer a diferença, que eu não ia fazer aquilo. Até hoje eu tenho uma chefe e ela olha pra gente como se a gente fosse inferior a ela, por ela ser enfermeira, onde eu trabalho. $E$ hoje, como eu faço faculdade ela já fala comigo em outro tom, ela não fala mais como falava antes. Antes de eu fazer faculdade, ela fala outro linguajar, agora ela é mais calma, ela fala: "Vocês entendem, né? Vocês estudam..."eu queria também entender a cabeça do enfermeiro, do que se passava. Hoje vejo que é uma responsabilidade maior. Auxiliar e técnico é aquela coisa mastigada. Sabe que o sangue corre pela aorta, mas não sabe por onde, que corre dentro da aorta. Ser enfermeiro é algo mais complexo.

Sempre estive no meio da enfermagem, minha filha teve câncer aos 6 anos. Meu filho está 10 anos, mas sempre teve bronquite, sempre ficou internando, já parou. Eu era simples dona de casa e disse: "Acho que é isso que eu quero pra minha vida. Vou seguir a carreira de enfermagem". Fiz o auxiliar e o técnico de enfermagem. Como eu trabalho de apoio ao SAMU, sempre trabalhei com isso. Falei: "Agora eu preciso progredir mais, saber mais" e aí resolvi fazer a faculdade de enfermagem.

Minha filha teve câncer aos 6 anos de idade, eu me via dentro do hospital, orava dentro do hospital. Minha filha fez somente três quimio, graças a Deus. Vi o processo como eles tratavam ela. Era diferenciado do infantil e do adulto. No dia da cirurgia o médico abriu ela e me chamou: "Olha mãe, você vai ter que ser forte. Sua filha está com câncer dentro da mandíbula". O dente da minha filha esfarelava. Eu não conseguia entender aquilo. Meu filho também tinha crises de bronquite.

Meu marido é feirante, é um profissional liberal, autônomo. Fiquei a pensar com meus botões: "Se ele me faltar amanhã o vou fazer da minha vida?". Ele paga INSS, mas e aí e eu? Ficar com duas crianças a Deus dará? Falei pra Deus: "Eu vou 
fazer enfermagem". Eu tava saindo de casa nesse dia pra fazer matrícula e eu falei com Deus: "Senhor se for da sua vontade, que seja feita, mas me de uma certeza se é isso que eu preciso". Quando saí de casa, meu vizinho foi atropelado, o pé dele abriu em dois pedaço, fui lá, não coloquei a mão, mas auxiliei, porque ele tava desmaiando, um sol muito quente. Ali eu tive certeza, todo mundo correu quando viram aquele pé, praticamente decepado. Eu não, fiquei ali até o SAMU chegar. Eu olhava para o SAMU e isso me encantava. Isso ocorreu há 6 anos atrás. E quando eu entrei no SAMU, falei: "Meu Deus eu não sei fazer outra coisa”, já tentei outras áreas. Eu trabalhei no Sírio Libanês, em Home Care, no PS de Suzano. Foi a primeira opção fazer a faculdade de enfermagem, não me vi fazendo outro curso.

No momento da escolha, tive apoio total, unânime. Amigos, marido, filhos, foi unânime. Chegava no PS, eu tinha conhecidos, alguém sempre perguntava: "E aí o que você tá fazendo?"; "Faculdade de enfermagem"; "Ah enfermagem? Olha para gente, o lixo que a gente é". Eu até brincava com eles: "Preciso virar chefe pra mandar em vocês. Eu preciso judiar de vocês. E eu preciso de um cargo superior pra poder fazer isso" (risos). Eu sempre brincava, mas os próprios colegas da regulação foram contra. Muitos, muitos, não foram duas/três auxiliares, muitos que falavam: "Ah enfermagem? Vai fazer engenharia que dá dinheiro. Advocacia que dá dinheiro". Não, eu vou fazer enfermagem, não sei fazer outra coisa. Até daria certo se fosse assistente social, mas até hoje não sei o Estatuto da Criança e do Adolescente, não sei (risos). Nunca vai entrar na minha cabeça (risos).

Acho que se a metade tivesse a cabeça que tenho, o que eu penso hoje, acho que ia fazer diferença. Não destratar o auxiliar, o técnico, a faxineiro, o pessoal da remoção, o pessoal da ambulância. O enfermeiro também é burocrático, você precisa de uma vaga, então você tem que se virar com a vaga. Eu quero, penso fazer diferença. Eu preciso disso. Mudando o comportamento, você muda a visão que se tem do enfermeiro. A visão que eu tinha, hoje eu não tenho tanto, mas muita gente tem. Essa rivalidade. Já começa pelo jaleco azul. Essa necessidade de colocar o jaleco azul no trem, no ônibus, no metro, pra poder diferenciar do técnico. Sendo que todos nós estamos em busca da saúde, um diploma tá diferenciando a gente. Muitas vezes o técnico sabe mais que uma enfermeira. Vivenciei isso na parada Gay. A gente foi trabalhar na parada. A enfermeira não sabia o que fazer, ela não sabia puncionar. Ela: "Acabou o soro pra fazer a glicose”. Estoura no copo, põe um pouquinho de água e dá para o cara beber. Uma coisa que ela não tem iniciativa. 
Não tem a pegada. Aonde você se formou? "Ah, eu fiz Uninove, eu fiz Anhanguera”. Só faculdade de nome, mas na hora do vamos ver, da pegada, travava. Tinha uma que ficava no meu pé. "Tudo o que você fizer você me ensina?". Não me custa nada, eu não nasci sabendo, não sou melhor do que ninguém, "mas você é enfermeira, né?" Tudo bem, acho que todo mundo tem o direito de começar, ninguém nasceu sabendo. Estágio e uma coisa, na pegada é outra. Que nem o APH nos 5 certos. Você não vai fazer os 5 certos num $\mathrm{APH}$, não dá tempo. Você vai fazer visão geral, mas achei a enfermeira muito crua, uma mulher extremamente crua que colocaram ali. E sabe-se que no hospital que elas têm o nariz empinado, infelizmente tem muito. Queria que mudasse um pouco essa rivalidade. Isso incomoda!. "Ah, eu não vou porque isso é obrigação sua". Não, a obrigação é de tudo mundo, é igual. Paciente parado, não tem essa se é o médico, o auxiliar ou técnico. Se você tiver dentro de um hospital todo mundo tem que ir pra cima. Quantas vezes a gente tá levando uma ficha, você vê lá seu colega fazendo uma manobra. Você ajuda. Quantas vezes eu fiz isso? Quantas vezes as meninas fizeram isso. Apesar de que no PS de Suzano tem uma equipe que não tem esse "Ser superior a mim". A enfermeira fala: "Oh, pede ajuda porque eu não sei fazer não", "olha me ajuda a fazer uma gasometria que eu não lembro não". Acho que falta muita humildade. 


\section{Participante 8}

Enfermeiro pra mim não é somente cuidar de pessoas, é lidar com vidas, com os sentimentos das pessoas, porque quando a pessoa chega no hospital, chega debilitada mentalmente, em vários sentidos. Em minha opinião ser enfermeiro é você cuidar de um todo da pessoa, tanto da parte física, quanto da mental do paciente.

$\mathrm{Na}$ realidade sempre tive muita dúvida do que fazer. Nunca acertei que curso que queria fazer e seguir. Sempre tive muita dúvida. Quando me apareceu a oportunidade de diversos cursos, optei pela enfermagem, pelo fato de cuidar de pessoas. E é uma coisa que gosto. Tive casos na minha família de câncer, pessoas debilitadas, acamadas, precisando de ajuda. Foi aí que comecei a me identificar com a enfermagem. A partir dos casos da minha família, comecei a me interessar pela enfermagem. Isso aconteceu quando eu tinha mais ou menos uns 15 anos.

Não fiz auxiliar/técnico de enfermagem, entrei direto na faculdade. Quando entrei, tinha muito receio de começar e não gostar ou de repente não ser aquilo que queria, mesmo tendo gostado de ter cuidado de pessoas na minha familia, de ter ajudado. Na igreja aonde vou, a gente ajuda pessoas, tanto com doenças, quanto mentalmente, que estão precisando de ajuda, de conselho, foi aí também que me motivou a escolher enfermagem.

Quando entrei na faculdade, surgiu um pouco de dúvida pelo fato de eu ver tantas pessoas que já tinham o auxiliar e o técnico de enfermagem e por já trabalharem na área. Entre a sala inteira eu era a única que não tinha o auxiliar e nem o técnico. Eu fiquei em dúvida por causa disso, eu tinha medo de repente de chegar no hospital e me deparar com pessoas e não saber cuidar pelo fato de não ter o auxiliar e o técnico, mas de um tempo pra cá comecei ver que a escolha de eu ter entrado direto na faculdade, na minha opinião, foi melhor do que ter feito um auxiliar ou o técnico. Não desmerecendo as pessoas que tenham o curso, mas pra mim, a melhor escolha foi eu ter entrado direto na faculdade, porque comecei a perceber que realmente é a carreira que eu quero seguir e porque vejo que as pessoas que têm auxiliar e o técnico se deparam com as mesmas dúvidas que eu tenho, mesmo tendo um curso e entendendo mais ou menos da área.

Quando decidi, definitivamente, ingressar na faculdade de enfermagem, foi quando minha tia teve câncer. Para ela se alimentar e ser medicada tinha que ser por sonda. Ninguém da minha família tinha coragem de dar alimento pra ela pela 
sonda. A única pessoa que tinha coragem de ajudar ela, de limpar, porque às vezes aparecia ferida, a única pessoa de que tinha coragem de estar ali com ela era eu.

Os amigos do serviço falaram que eu era louca, que não era uma área muito legal. Minha escolha não foi pensando no dinheiro, porque não tenho noção de ganhos de enfermeiro. Foi realmente por amor que começou com minha tia e foi aí que eu decidi. Na minha família, a única que aprovou essa decisão, foi minha mãe. Meu pai, meu irmão e minha irmã, não aprovaram. Falam que essa área não é boa, não é reconhecida. Não é uma área que você olha e fala: "Essa pessoa é reconhecida por ser formada nisso". Eles acham que não é uma área reconhecida. No começo meu marido não aceitou, mas agora ele aceita, mesmo assim ele disse: "Pensa direitinho, não é uma área legal. Por que não faz curso de licenciatura pra dar aula, faz pedagogia. Ao menos você vai lidar com crianças, é mais fácil". Hoje em dia ele aceita, mas no começo foi difícil. Logo quando eu comecei, ele não aceitava não de jeito nenhum. Minha filha tem 5 anos e não tem como dar palpite. Minha irmã, meu irmão e meu marido rejeitaram minha escolha e toda vez que a gente conversava eles falavam: "Não acho que é um área legal. Por que você não faz farmácia, já que você optou pela área da saúde? Faz odonto?”. Eu sempre batia o pé dizendo que ia fazer enfermagem.

Se eu falar que não penso financeiramente, eu seria hipócrita. Penso em ter uma vida estabilizada. Penso principalmente em ser realizada profissionalmente, de estar trabalhando numa área de que realmente gosto. Imagino que deve ser muito horrível você passar sua vida inteira fazendo uma faculdade, quando você se forma vê que não é nada daquilo que você queria fazer. Pretendo mesmo lecionar em faculdade, quero trabalhar em hospital pra adquirir experiência. Espero que seja uma área mais reconhecida, não somente para os enfermeiros, mas para os técnicos e auxiliares. Espero que seja mais reconhecida, não que não seja, é, mas espero que seja mais. Pelo esforço do enfermeiro, do auxiliar, do técnico; pela dedicação, de estar ali, de ter cuidado, de ter paciência com os pacientes, porque nem todos pacientes são iguais, tem uns que estão mais debilitados, tem uns que vão te tratar bem, outros não. Espero que seja mais reconhecida no futuro. Espero que seja reconhecido na minha família, não somente em mim, mas nas outras pessoas da área, porque eles reconhecem que dá dinheiro, porem não é reconhecida pelas pessoas. Espero que seja reconhecida pela minha família por mim, pelos profissionais. Porque acho que todos os profissionais da enfermagem 
são pessoas bem batalhadoras. Todos que estão nessa área têm que gostar muito, porque senão, não fica. 


\section{Participante 9}

Se enfermeiro é poder se doar totalmente para ajudar outras pessoas. Ter dedicação. Enfermeiro trata de vidas. e sabendo tratar bem a outra, como a si mesmo, ela vai muito além, dar um bom atendimento.

Achava bonitas aquelas pessoas de branco, bem arrumadas, sempre me interessei, desde infância. Desde pequena eu brincava de médico, eu era a médica. Minhas bonequinhas sofriam (risos).

Meu pai teve vários problemas, eu ficava com ele no hospital. Fez várias cirurgias. Foi crescendo o interesse em aprender. Eu tinha mais ou menos 15 anos. Quando realmente eu vi que queria fazer enfermagem foi quando meu pai precisava de ajuda e eu não sabia fazer. Eu pensava: "Nossa se eu soubesse, eu poderia fazer, ao invés de esperar de outras pessoas". Quando ele teve alta, ele precisava de alguém pra fazer curativo e sempre precisava de outras pessoas e elas nem sempre estavam disponíveis. Como eu já tinha esse interesse, não totalmente pela enfermagem, interessa-me a medicina, sempre gostei! Meu pai operou do coração e mais uma vez eu fiquei com ele. Via o jeito que os enfermeiros tratavam ele, me fez ver que o enfermeiro não é só um profissional, é um amigo, porque tá tirando um pouco do tempo dele pra se dedicar ao paciente. Também, fiquei com minha avó. Fui percebendo o que realmente eu queria. Eu disse: "Vou ter que estudar". Tentei várias vezes prova pra faculdade de enfermagem não aqui, no Maranhão, mas nunca dava certo, porque toda vez ou eu estava trabalhando. Da primeira vez foi assim: eu tava trabalhando, fiz a prova, passei, eles deram um prazo para levar todos os documentos, mas não deu tempo de chegar lá. Aí não deu. Era faculdade particular, pelo Fies. Da segunda vez o Fies não liberou não sei porque, porque eu sou pobre (risos). Esse ano fiz novamente prova e deu certo, e fui.

A enfermagem foi minha primeira escolha. Minha mãe dizia: "você não quer fazer advocacia?" eu dizia: "não, quero fazer enfermagem”. Porque a gente sabe também que não é aquela coisa fácil, não é reconhecida, por mais que o salário seja bom, nunca vai ser o bastante. O que importa mesmo é a pessoa dar de si para ajudar o outro, acho que isso pra mim é o que importa, não é tanto o salário não, porque eu poderia ir pra advocacia e ganhar um pouco mais (risos).

No processo da escolha pela enfermagem, de primeiro momento minha família ficou na dúvida, porque sabem que é uma área que requer muito. Teve um 
irmão que disse: "primeiro faz o técnico, aí vai subindo". Eu disse: "Não. Se abriu essa porta é nela que eu vou entrar". Mas não teve problema não, eles sempre apoiaram minha decisão. Minha mãe dizia: “É isso mesmo que tu quer?". Porque é uma área que tem muitas portas para entrar, mas não é uma área reconhecida como deveria. Eu disse: "É isso mesmo que eu quero". Então, ela apoiou. No final todos apoiaram.

No futuro, espero ser que a enfermagem reconhecida. Pretendo trabalhar na área da enfermagem. Dar o melhor de mim. Pretendo conhecer mais detalhes sobre a área e mais pra frente não quero ficar parada na enfermagem, quero estudar medicina, uma coisa mais objetiva. Sou uma pessoa que não gosta de ficar parada, gosto de estudar até chegar ao ponto onde quero chegar, mas pra isso a gente tem que começar lá de baixo, não desvalorizando a enfermagem, mas é isso. A enfermagem precisa de muita coisa. Se olharmos para a rede pública. Às vezes o enfermeiro tá dando tudo de si e o paciente acha que é culpa dele, mas às vezes não é. Às vezes não tem benefício, não tem estrutura, materiais necessários. $\mathrm{Na}$ nossa sociedade não tem recursos, acho que é muito mal distribuído, tanto pra saúde, quanto para educação. Devia ser uma área melhor bem remunerada, com mais estrutura. Quem sabe teremos uma pessoa que diga "vamos dar mais atenção à saúde". 


\section{Participante 10}

Ser enfermeiro pra mim é doar uma parte de si do seu tempo. Dedicar ate mesmo para um ser humano desconhecido. Pra mim, uma profissão como enfermagem e medicina é algo surpreendente, porque é ciência, tem suas determinações, mas também tem que existir o amor, o carinho, porque a gente vai cuidar de outra vida. Porque se você vai exercer a função de enfermagem por conta de valores, você não vai fazer aquilo por amor, vai fazer por interesse. $E$ fazendo isso, você traz prejuízo a uma vida, porque poderá praticar a negligência. Enfermagem pra mim é algo especial, porque você vai dar seu tempo pra cuidar de uma outra vida.

Não tive nenhum incentivo de ninguém. Desde a minha infância e adolescência sempre quis, sempre tive vontade de exercer essa função. Quando criança brincava. Geralmente a gente brinca como professor ou como médico. Eu gostava de brincar como enfermeiro. Somos em 6 irmãos. A gente brincava de escola. E quando era enfermagem a gente pegava as bonecas. Tinha umas irmãs que dizia que era médica e eu era enfermeira. Batia na porta: "Licença". Injetava seringa de brinquedo no braço da boneca. E assim a gente brincava, dizendo que tava medicando, internando, deixava a boneca em uma caminha dizendo que era leito. Na adolescência eu era muito de observar. Quando alguém vinha me medicar eu ficava observando como era feito. Na escola eu me interessava mito com a parte do corpo humano, genética, como eram tratados os problemas de saúde. E quando eu ia levar alguém, ou quando eu ficava de acompanhante, como eu fiquei com minha avó que ficou internada um bom tempo. Vinham os enfermeiros e eu ficava observando o cuidado. Eu via todas as funções que eles faziam, porque às vezes tem enfermeiro que não só dá medicação, eles têm aquele cuidado também da higiene que faz parte também.

Quando eu fui ter meus filhos depois da adolescência, depois que casei. Tive dois filhos em seguida, um com 24 e outro com 25. Eu notava a diferença de um enfermeiro para outro no cuidado. Tem aqueles enfermeiros que vem sem você precisar chamar, ele vem no horário certinho, ele é dedicado. Dá bom dia, boa tarde, boa noite, independente da hora que ele for. Eu lembro que quando fui ter meu primeiro filho, eu não sabia que eu não podia levantar da cama sozinha após o parto, porque a gente fica fraca. Eu levantei, minha sorte é que tava passando uma 
enfermeira e ela foi muito gentil comigo, porque eu não sabia, não tinha noção de nada. Ela chegou, me segurou nos braços, ela não era do setor, só tava passando. Ela me disse: "Você não pode levantar". Orientou-me quanto as horas que eu teria que fazer de repouso. Ela falou: "Você não levanta enquanto não vier a enfermeira do setor. Eu não posso tocar em você porque aqui não é meu setor. Eu só posso liderar onde eu estou. Mas fique deitadinha aqui. Vou dar um biscoitinho. Eu não posso fazer isso no momento. Mas vou ter dar um biscoitinho, uma bolachinha pra você aliviar mais essa tontura e não levante". Lá chamou a pessoa responsável pelo corredor. A pessoa me levantou pra me dar meu banho e me alimentou. Quando foi no dia da alta, coincidiu dela ir com um grupo, dando informações sobre o aleitamento. Ela tava com nutricionista ou com a pediatra, não lembro. Ela disse "foi você, mocinha teimosa, né?" Brincando comigo. Eu nem lembrava (risos). Pra mim era uma loira, mas foi uma morena. Eu disse: "Fui eu?" Ela disse: "Foi. Eu falei que não era pra levantar, mas você insistiu de novo. Quando eu dei as costas, você estava quase no chão. Se não fosse eu passando aqui você ia cair". Eu disse: "Fui eu mesma" (risos). Eu achei isso muito prazeroso por parte dela. Porque não era obrigação dela me ajudar porque não era neste andar que ela tava liderando. $E$ ainda lembrou do meu rosto. Eu acho isso bonito. Acho que isso é um trabalho respeitável. Outro ser humano dando sua dedicação, seu tempo. Somos falhos, mas se você se dedicar com carinho já é bom.

Minha escolha pela enfermagem foi por conta do cuidado. Eu disse: "Um dia me tornarei enfermeira e darei o meu melhor e farei diferente de muitos enfermeiros. Porque existe o enfermeiro e o enfermeiro". Tem uns que só escolhem enfermagem, professor, doutorado por conta de valor. Outros vão por vocação, determinação e amor por aquilo. Eu já passei por situações boas e ruins. A minha determinação foi maior também pra poder mostrar, ensinando. Temos que nos incentivar com os erros das pessoas, e dar o melhor e vê que o mundo da pra melhorar. Você fazendo diferente.

Quando tinha 26 anos, fiz três cirurgias em um dia só (duas hérnias inguinais, umbilical e vesícula). Quando foi na hora da refeição a enfermeira chega pra mim e disse: "Tá de alta". Eu perguntei: "Mas o médico não vem me olhar?". Porque geralmente na alta o médico tem que ir averiguar como tá o paciente. Se realmente tá bom ou não. A enfermeira me deu medicação "Você tá bem”. Eu disse: "Ainda dói muito. Isso é normal? É a primeira vez que eu faço uma cirurgia. Não sei”. Ela disse: 
"É normal, nada de manha". Ainda bateu assim (demonstrou com um tapa leve em seu braço). Eu achei uma ignorância. Porque mexeu no seu corpo, qualquer pedacinho você vai sentir. Eu querendo tomar banho. Não podia levantar sozinha. Fiquei só lá no quarto. Eu dava sinal, mas ninguém apareceria. E a enfermaria ficava bem próxima do quarto. Não custava nada alguém aparecer. Quando a enfermeira apareceu disse: "Vou chamar a auxiliar pra medicar". Quando veio a auxiliar eu perguntei "Quem é aquela senhora?". A auxiliar disse: "Ela é enfermeira. Ela me pediu pra medicar você e disse que você tá de alta, é isso?". Leu o papel. Eu disse: "Ela foi ignorante". Eu acho que se ela é enfermeira, ela tá ali liderando e age dessa forma ao invés de passar informação exata, né? Eu sei que ela não é médica, mas ao menos ela devia ter uma noção das orientações pós-cirúrgicas. A auxiliar agiu como a cabeça. Ao invés da cabeça agir, foi o corpo, o membro. Fiquei pensado, que diferença! Fiquei muito decepcionada. Porque se é um hospital público, mas uma coisa que você paga você pensa que terá um atendimento melhor, mas não. Esse hospital era privado. Isso balançou, pois fiquei pensando como um ser humano se dedica a uma profissão que mexe com vidas, com sentimento, emoções, porque ele tem uma vida dentro dele, ele tem um sentimento. Será que ele não para pra pensar "podia ser eu no lugar". Pra você se dedicar ao ser humano, como enfermeiro e médico, você tem que ter essa percepção. Podia ser o inverso.

Meus dois filhos nasceram no hospital público. Meu segundo filho nasceu em um hospital próximo de casa. A enfermeira obstetra foi super gente boa. Foi melhor do que o médico. Deu-me apoio. Viu que tava demorando. Minha bolsa não se rompia. Depois que rompeu no hospital, o bebê demorou nascer. Já tava passando da hora. Eu entrei cinco e meia da tarde e eu tava ficando esmorecida. O médico já tava irritado, ficando cansado, exausto de tanto esperar. Toda mulher entrava e saía e eu nada. Eu fui a primeira a entrar e a última a sair. A enfermeira paciente. Quando eu já não tinha mais força na mesa do parto. Ele ficou insistindo e queria até fazer um outro tipo de parto. A enfermeira disse: "Tenha paciência. Ela vai ter normal". Ela comprimiu meu abdome pra ajudar meu bebê sair. Mas ela sempre calminha. Comecei a gritar que eu não tava aguentando mais, tava exausta de tanto fazer força, com dor e demorou muito. Já tava me entregando às dores, já não tava nem mais querendo que o menino nascesse de tão cansada que eu tava (risos). Pior que fui abrir a boca pra gritar e não conseguia mais parar. O médico me disse "Larga de manha. Tem tanto menina novinha que não faz esse escândalo todo. Por que você 
tá fazendo todo esse escândalo?". Virou as costas e me deixou lá. A enfermeira disse: "Calma, porque não é ele que tá sentindo, ele é homem (risos). Se fosse ele, ele ia saber. Eu entendo você, mas calma, tá? Não grita, relaxa”. Ela foi me ajudando a fazer um esforço exato para o bebê sair. Isso também é uma outra coisa que a gente nota e guarda. Dizem que quando um líder saber liderar, as coisas vão bem, mas quando não sabe, as coisas pioram. É como se tivesse um cérebro que não funciona, seu corpo paralisa. Enfermagem pra mim é isso.

Sempre quis fazer enfermagem. Fui em outra faculdade antes de ter meus filhos. Tentei fazer inscrição, só que como eu tava na transição de mudança de horário no serviço, fiquei em dúvida se daria tempo ou não. Mas nesse interim, acabei engravidando do primeiro filho. Com dois meses depois de tomar a decisão de fazer a matrícula, descobri que tava grávida. Foi passando o tempo, veio o segundo filho. Fui deixando. Tava com período integral na empresa. Tinha que dividir meu tempo para meus filhos, meu marido, casa e trabalho. Veio minha irmã morar comigo, ela cursa enfermagem. Ela tem uma dedicação. Ela é voluntária no hospital. Ela cuida assim de uma forma que eu fico admirada! Não é porque é minha irmã não. Ali da pra ver que tem vocação. Ela cuida de idosos, crianças. Ela tem um carinho tão especial que ela vai com maior paciência. Ela trabalha com um grupo. Ela fala que tem pessoas que nem ligam. Por ser voluntária, ela tem que fazer algo relacionado a área da enfermagem. Ela vai lá limpa o bumbum. Ela veio e falou: "Vamos fazer a inscrição?" eu: "Ah não, tá muito puxado pra mim, o horário. Vou esperar ser mandada embora, porque terei tempo para meus filhos e tempo para estudar". Veio outra irmã, mais nova. Ela disse: "Vou fazer a inscrição". Fez a inscrição pela internet. Somos do Maranhão. Ela perguntou: "Você não vai?" Eu disse: "Não, mas vou lá te acompanhar", que ela não sabia vir. Cheguei e disse que ela ia fazer. Fui perguntando e vendo se tinha possibilidade. O rapaz disse: "Você não quer fazer também? Aproveita!", me explicou tudo. Eu tava só com meu crachá. O rapaz disse: "Você faz uma prova. A gente vai analisar. O dia que você vier fazer sua matrícula, você traz seus documentos". Eu fiz. Fiquei aguardando, mas não estava nem esperando. Depois ligaram para ela e para mim confirmando que eu poderia levar minha documentação e fazer enfermagem. Pensei: "Vou encarar, mesmo que sacrifique o tempo para meus filhos, mas eu vou. Porque lá na frente eles podem precisar também" Nessa área, você pode não só cuidar de gente de fora, você pode cuidar de um parente. E como tem meu pai que já fez cirurgia do 
coração, a minha mãe também, eles vão ficar idoso. Não vou precisar contratar, vou cuidar com maior prazer, retribuir o que eles fizeram por nós.

Tenho primos que trabalham na área e disseram: "Nossa! É uma profissão muito bacana, muito legal!". Meus pais falam: "Se esforce, se dedique. Não te preocupe, eu cuido dos seus filhos. Quanto tu tiver já exercendo sua profissão, você vai ter tempo pra eles. Eles estarão maiores. Eles vão entender". Eles ficam me tranquilizando. Minhas irmãs também me apoiam. No inicio é muito trabalho, muita prova. Intervalo é pequeno. Pra eu conseguir me encaixar, vai demorar um pouco. Meu esposo também me apoia. Inclusive ele ta fazendo ciências biológicas, é parecido (risos). Não lembro de alguém ter sido contra. Ate com os colegas de trabalho. Quando comentei que fiz a inscrição pra enfermagem, ate minha líder falou "não sei porque, mas você tinha cara de enfermeira mesmo". Eu disse "Só porque eu falei que vou estudar enfermagem, já tenho cara de enfermeira?". Ela disse "Não, mas antes mesmo de você falar, você já tinha o jeitinho não sei porque".

Sei que não vou me arrepender. Espero que eu tenha bastante saúde, tempo para aproveitar. E o que eu puder fazer por alguém, que eu consiga. Até mesmo de evitar da pessoa passar dessa vida pra outra. Se for possível, eu farei. Muitas vezes a pessoa tá no leito sofrendo, e às vezes o familiar deseja que acabe logo aquele sofrimento. Eles vão sofrer porque não querem perder, mas também não querem continuar sofrendo pela pessoa que está ali, que não tem resultado de melhora.

No futuro, desejo que Deus ilumine minha mente me dando sabedoria e capacitação para eu ir até o final, até me aposentar (risos). Gosto muito da parte cirúrgica e de obstétrica, pois sempre tive curiosidade de saber como se é formado e gerado o bebê, como é o processo de cicatrização. Gosto muito de mexer com o corpo do ser humano.

No futuro, para a área da enfermagem, espero melhorias, pois há muitos enfermeiros que se dedicam e não têm valor, dependendo do lugar que ele está exercendo a função, porque eu já vi enfermeiro padecer. Cheguei presenciar o enfermeiro desesperado sem saber o que fazer, por conta das condições do hospital. Já presenciei isso na rede privada. O enfermeiro querendo exercer sua função ali dentro e não ter condições, pelos materiais. Têm pacientes que querem descontar nele, por ser cabeça da equipe. Eles não são culpados, eles estão representando o gerente, dono, sei lá, do hospital. Já vi enfermeiro resolver as situações, mas nem sempre ele consegue. Seria bom se tivesse mais valor. Agora 
que estou estudando, já cheguei a dizer que foi o médico, mas eu tô vendo exatamente que não é o médico e sim o enfermeiro que faz acontecer. Que o ser humano entenda qual é a função do enfermeiro no hospital. Se pudesse, deveria ter palestras nos hospitais, explicando a função do enfermeiro. Seria bom que o enfermeiro tivesse um reconhecimento melhor. Que nem tudo que acontece é pelo médico. Cada um tem sua posição no hospital. Que as pessoas respeitassem a posição de cada um no hospital, principalmente os pacientes. 


\section{Participante 11}

Eu já fiz auxiliar de enfermagem no ano de 2003. Parei porque naquela época acabei casando. Em 2013 voltei a fazer, mas parei por causa das condições financeiras. Moro sozinha aqui em São Paulo e as coisas ficam puxadas. Agora que tive a oportunidade de fazer, de acordo com o plano da faculdade eu tô realizando um sonho meu. Eu amo a área da saúde. Me fascina ver como o corpo da gente funciona, de tão perfeito que ele é.

A primeira vez que eu fiz o auxiliar eu foi por volta dos 30 anos, cheguei a concluir. Eu amo! É uma paixão muito grande que tenho. Tô realizando um sonho meu. Quero ir até o final, se Deus quiser, concretizar e poder ajudar algumas pessoas.

Muita coisa muda constantemente, então, o que a gente usava naquela época do auxiliar já não é mais a mesma coisa. Então, eu disse: "vou começar do zero", e o nível superior é bem diferente do que um técnico. Técnico eles dão uma pincelada, não é tão profundo como é o ensino superior. O que aprendi naquela época, que nem agora na parte da citologia que é célula, o que aprendi naquela época até mesmo 2013, é totalmente diferente do que é agora. O ensino é bem mais profundo, bem mais detalhado.

Ser enfermeiro em si é uma grande responsabilidade, porque está lidando com vidas. O médico prescreve o que precisa ser feito, quem vai por a mão realmente é o enfermeiro. Ele que fica com a parte maior de responsabilidade. Ser enfermeiro é uma responsabilidade muito grande, é a satisfação de você ver a saúde do paciente, o desenvolvimento dele, a evolução dele. Claro que existem os óbitos, que acontecem, a gente tem que ser forte para encarar isso, mas o foco principal é você fazer o bem, cuidar do paciente e fazer de tudo o melhor para que ele possa ter alta e seguir a vida bem.

O processo de escolha da enfermagem começou quando eu descobri que eu era diabética, tinha 19 anos. Foi um choque muito grande, perdi 10 quilos. Os médicos suspeitavam que estivesse com câncer, porque emagreci muito. Como era jovem, não queria saber de ir ao médico. E meu pai querendo me levar e eu não queria ir. Eu só passava mal. Já estava com 4 dias internada no hospital e entrei quase em coma. Eu falo que estar viva é um milagre de Deus, por ter passado tudo o que passei. Já tive várias complicações. Devido essa doença, acho que despertou 
em mim a vontade de estar na área da saúde. Na época eu não podia ver sangue, agulha, nada e tive que aprender aplicar em mim, aprender mais o que era o diabetes. Pensei: "Vou procurar alguma coisa relacionada a área da saúde pra eu aprender mais". Já fiz curso de auxiliar de farmácia; curso de auxiliar de laboratório e comecei a fazer auxiliar de patologia, que hoje é conhecida como análises clínicas, mas parei o curso no meio do ano, porque meu pai adoeceu e como eles tinham se mudado eu fui ajudar minha mãe. Ele morreu de câncer. Minha meu falou: "Como você já fez enfermagem, vem me ajudar que eu vou precisar de você". Tudo o que é em volta da área da saúde eu tô indo atrás.

Após a descoberta do diabetes, os dois primeiros anos foram meus anos de rebeldia, porque eu não aceitava de maneira nenhuma. Tive que ter a consciência do que podia acontecer comigo futuramente, das consequências. Despertou-me a vontade de aprender e também ajudar as pessoas.

A faculdade de enfermagem foi minha primeira escolha. Lembro que quando eu fiz estágio no auxiliar de enfermagem, estagiei por 2 anos e meio no Hospital do Heliopólis, no meio da favela. Não vou falar que não chorei. la para a sala de enfermagem chorar dizendo: "Por que aconteceu isso?". Lá tinha muitos moradores de rua. Quando a gente chegava, eles ficavam super felizes porque realmente a gente cuidava deles. Dava banho, trocava roupa, comida. O que me deixou muito triste, foi ver que o pessoal de enfermagem, geralmente eram duas enfermeiras no andar, elas o deixavam sujo na cama, não tava nem ai. Era muito bonito ver a felicidade deles ao nos avistar. Não custava nada fazer o serviço e em retribuição recebíamos esse amor por parte deles. Isso eu fiquei muito feliz de ver e ao mesmo tempo indignada de ver como tem ser humano, que se forma, faz um juramento e deixa um indivíduo no leito sujo, sem comer, sem trocar fralda. Essa parte que fiquei indignada. Faz tempo isso, não sei como os hospitais estão hoje em relação a isso e até mesmo lá. Mas isso me incentivou de querer me formar e ser útil pra alguém. Essa situação me abalou, não no sentido de desistir da enfermagem, mas ao contrário, quero fazer a diferença. É uma experiência que eu levo para o resto da vida.

$\mathrm{Na}$ minha escolha pela faculdade de enfermagem, minha mãe e meu irmão sempre apoiaram, ficaram radiantes. Tive uma repercussão muito boa. Sempre gostei da área da saúde, sempre fui estudiosa, tipo CDF, sempre gostei de estudar, 
então não tive problema com estudo. Tive apoio 100\%. Até mesmo de colegas de trabalho, me incentivaram bastante.

No futuro pretendo trabalhar na área, porque a gente estuda tanto e quer exercer. Espero que as coisas sejam melhores do que são hoje. A gente sabe que o enfermeiro não recebe muito bem, acaba trabalhando em vários hospitais pra ter um melhor sustento. Quero concluir o desejo, para que o sonho seja realizado. Espero que a profissão de enfermagem seja mais reconhecida, no geral, como um todo, como pessoa, como ser humano. Porque trabalhar como enfermeiro precisa gostar. Muitos escolhem a enfermagem por causa da parte financeira, porque ganha bem, porque acaba trabalhando em vários. Mas o foco principal é o cuidar do ser humano, esse amor que você tem que ter pelo próximo. Acho que muitos acabam deixando de lado. 


\section{Participante 12}

Pra mim, nesse momento, ser enfermeiro é uma realização. Por conta do meu irmão que era esquizofrênico, problemas de saúde na família, uma realização pessoal. O enfermeiro é uma pessoa muito importante para a sociedade, algo que não pode faltar, tudo mundo precisa.

Cursei o auxiliar e o técnico de Enfermagem e foi por conta da minha mãe, pois ela era atendente, trabalhou 10 anos no Santa Marcelina de Itaquera. Tentei me envolver em alguma coisa, pensei em Educação Física, pensei em várias outras áreas, mas não me identifiquei com nada, aí eu fiz enfermagem, mas minha primeira escolha foi enfermagem mesmo. Na verdade quando eu comecei a fazer o auxiliar, falei: "Acho que não é isso que eu quero pra mim". Então, fui ver se eu me enquadrava em outra coisa, mas depois eu fiquei pensando "não sei fazer outra coisa, só sei fazer isso mesmo". Atualmente trabalho no SAMU, há 3 anos, como auxiliar de enfermagem.

A minha mãe adorou a ideia, adorou! Porque ela já era da área, trabalhou 10 anos, então, ela adorou! Meus irmãos gostam também, embora um seja professor de Letras, mas ele achou super legal, me incentiva. Não teve ninguém da família que foi contra. Os vizinhos e os meus amigos falam: "Nossa! tanta coisa pra você fazer, você vai enfermagem? Não dá dinheiro. É uma coisa tão perigosa". Essas pessoas que eu tenho vínculo, eles vão muito pela questão financeira. Acho que você não tem que procurar algo pra fazer que ganhe muito. Tem que procurar o que gosta. Trabalhei 3 anos e meio em Telemarketing, eu odiava!! Eu tinha que sair da minha casa forçada, pensando: "não acredito que eu vou trabalhar!!". E eu não quero mais isso pra minha vida. Quero acordar cedo e falar: "ai que legal, hoje eu vou trabalhar; hoje eu "to" de plantão". Então, o meu bem-estar vem primeiro que a minha visão financeira.

Para o futuro do enfermeiro, da enfermagem, espero melhorias. Por mais que enfermagem seja legal, tem um déficit muito grande. Eu digo pela minha cidade. Suzano não é uma cidade tão pequena, mas também não é tão grande. Só que o nível da saúde lá é péssimo, tantos para os profissionais como para os pacientes. Então, espero uma melhoria. 


\section{Participante 13}

Enfermeiro é cuidar do próximo. Prestar os devidos cuidados. Ter uma preocupação com a dor, o sentimento, psicológico do próximo. Hoje a gente cuida, amanha a gente tá lá. Gosto de pensar que tô cuidando de uma forma que amanhã a pessoa vai cuidar de mim. Se eu maltratar, da mesma forma amanhã quando eu precisar desse cuidado, serei maltratada também.

Na minha família não tem ninguém da área da saúde. Lembro que na primeira série, no Mato Grosso, a gente usava um caderno de caligrafia, mesmo quem não precisasse usar. A professora perguntou o que a gente queria ser quando crescer. Eu falei que queria ser médica, mas sempre gostei da área da saúde, sempre me interessei por medicina, medicina veterinária, enfermagem. Eu ficava na dúvida. Tinha um professor que todo dia ia de branco, pensei "um dia vou perguntar pra ele". O pessoal brincava dizendo que ele era pai de santo. Então, perguntei "Professor, o que o senhor faz?" Ele falou: "Eu sou enfermeiro". Perguntei: "O que é ser enfermeiro? Ele falo:u "É bacana! Por que você ta perguntando?" Eu respondi: "To pensando no que vou fazer". Ele me disse pra eu fazer um curso técnico que daria pra eu ter uma ideia do que era a área da saúde. Ele dizia que muita gente escolhia a área da saúde por causa do pai, da mãe, do tio. Então, fiz curso de auxiliar e técnico de enfermagem e trabalhei na área. Comecei como cuidadora, no Home Care.

Quando comecei a faculdade, eu era casada e meu marido não aceitava, dizia que enfermeira era "lanche" de médico. Ele dizia que o curso era caro e que eu ia investir muito dinheiro e não saberia se eu ia ter retorno. Meus pais aceitaram super bem, eles encaram a enfermagem de uma forma bacana, acham bonito. Independente da profissão, os pais sempre querem ver o filho formado e nessa área eles acreditam que eu possa ajudar com minha prática, caso ocorra algum problema na família, em uma necessidade.

No futuro, espero que a enfermagem seja mais reconhecida, pois é muito desvalorizada. Ela tem o valor dela, apesar dessa questão da historia do gênero (feminino/ masculino), dessa ideia da enfermeira ser prostituta. A gente tem um Conselho que tá ali pra poder a gente, entre aspas. Mas esse Conselho existe só por existir. Há situações que todos os profissionais da área da saúde passam, o pessoal apanha. Os pacientes às vezes precisam de uma resposta referente a 
alguma coisa dentro do hospital, que não é da competência do enfermeiro fazer. Quando estudamos, aprendemos sobre imprudência, imperícia e negligencia, mas o dia a dia é complicado. Não temos suporte. 


\section{Participante 14}

Antes eu tinha uma visão bem diferente do que tenho hoje da enfermagem. Minha mãe trabalha na área da saúde, como técnica de enfermagem há 20 anos. Nunca me interessei pela área. Até uns 5 anos quando fiz o curso técnico de enfermagem. Depois do curso, pude ter contato com os enfermeiros. Vi que no hospital a enfermagem está presente em $70 \%$. O enfermeiro é muito o espelho do paciente. O paciente relata muita coisa para o enfermeiro e não relata para o médico. Vejo muito isso. Ele reclama de muita coisa sobre os exames, os procedimentos, mas não reclama para o médico. $O$ enfermeiro acaba sendo um pouco de psicólogo, um pouco de padre, mas acho a enfermagem uma profissão muito bonita! Comecei a olhar de forma diferenciada.

Tem muita gente que tá ali em uma mesmice, como em qualquer área, mas tem muita gente querendo fazer a diferença, querendo cuidar. As relações humanas são difíceis. É difícil lidar com o ser humano. Somos complicados. Quando ficamos doentes, ficamos fragilizados. O enfermeiro acaba sendo o porto seguro daquela pessoa que está necessitando de cuidado, às vezes até de alguém que somente o escute, principalmente no hospital público. No SUS e até em hospitais particulares tem muito paciente que não tem familiar e o enfermeiro acaba virando um pouco a família dele. O cara tá ali internado por 2, 3, 4 meses. Cheguei a cuidar de uma paciente por um ano e meio direto, é muito tempo! Você passa natal, ano novo, páscoa, aniversário.

Quando pensei em fazer faculdade, quis sair da enfermagem. Fiz um ano de odontologia e não gostei e voltei para a enfermagem. Acho que a profissão que me escolheu, gosto muito do que faço! Quando queremos, fazemos a diferença para a pessoa que está precisando.

Acredito que o enfermeiro é visto pela sociedade com respeito. Percebemos certa desvalorização. Não temos um bom salário, mas acredito que o enfermeiro é um profissional bem respeitado, quando a pessoa faz com amor, dá pra perceber a diferença.

Minha mãe é técnica de enfermagem e falava que eu levava jeito. Ela nunca trabalhou em hospital, sempre trabalhou com paciente particular. Ela contava as coisas e eu dizia: "Não quero isso pra minha vida!". Tanto que quando eu tinha uns 23 anos, fiz um semestre de Letras, porque sempre gostei de dar aula, de ensinar, 
tinha conseguido uma bolsa no Pro Uni parcial e eu tava sem condições na época, meu marido ficou desempregado, parei e fiquei uns 4 anos sem estudar. Eu trabalhava em uma empresa que gostava muito, na globo.com e fui demitida de uma hora para hora. Fiquei tão chateada! Pensei: "Preciso fazer alguma coisa, não posso fica parada. O tempo está passando e tô ficando velha”. Minha mãe sempre insistiu muito pra eu fazer o curso de enfermagem, alegando ser uma área boa, que tem emprego. A gente pensa muito nisso quando escolhemos uma profissão. Ninguém quer estudar 4/5 anos em uma faculdade e ficar em casa sem serviço. De repente, estava olhando a internet e vi que a Escola da Santa Casa tava fazendo processo seletivo para o curso auxiliar/técnico de enfermagem. Prestei, passei. Adorei o curso. Trabalhei três anos lá e foi muito bom. Tem um amigo que fala que a enfermagem é uma profissão que ela que escolhe a gente. Por que quem quer trabalhar sábado/domingo por 3/4 mil reais? É pouco se pensar que tá abrindo mão do seu final de semana com seu marido, filho, pais. Abrindo mão do feriado. Já trabalhei virada de ano, natal, aniversario do meu filho, no meu. Mas acho gratificante.

Tenho uma amiga que é Espírita e diz que enfermagem é carma. Ela diz que todo mundo que trabalha na área da saúde é porque tem algum carma. Eu falo: "Então tô pagando meus pecados trabalhando na enfermagem". Mas, não me vejo em outra coisa. Tanto que quando fui para odonto, voltei para enfermagem. Minhas colegas falam que eu deveria fazer psicologia porque gosto muito de conversar. Quando fiz estágio na Santa Casa, ouvia muito a história dos pacientes, principalmente dos idosos.

No momento da escolha em estudar enfermagem, minha mãe apoiou. Tive conhecidos que foram contra, pois eles já eram da área e estavam com dificuldade em arrumar emprego. Tinha um colega do meu ex-marido que tinha feito o curso de enfermagem e nunca tinha arrumado nada na área, mas mesmo assim decidi fazer. Na Santa casa tinha um programa que ao fazer o curso lá você já podia trabalhar lá. Toda profissão é difícil no começo. Mas muitos falavam que ganhamos pouco, que ficar limpando bunda, que terá médico e paciente reclamando.

Meu sonho é abrir um Home Care. Quero fazer pós em geriatria. Gosto muito de trabalhar com idoso. Tenho uma amiga que é enfermeira da Santa casa que tem um Home Care. Trabalhei muito na empresa dela.

Daqui pra frente, espero que a enfermagem seja mais unida. Você percebe um grupo de pessoas muito desunidas. Às vezes minhas colegas acham que 
quando trabalhamos a área, temos uma visão diferente. Quando fazemos faculdade sem ser auxiliar a gente tem uma visão diferente. Vemos que há situações que precisamos do colega, mas às vezes não temos. São coisas infantis! Às vezes temos dúvidas, mas você tem vergonha de perguntar. Às vezes vemos enfermeiro na passagem de plantão falar mal do outro. Acho isso muito feio!! Minha mãe diz: "Educação vem de casa, não aprendemos na faculdade". Afinal, ninguém nasce sabendo. É muito difícil ver um médico falar mal de outro médico, eles são unidos. Gostaria que as pessoas fossem mais amigas, acolhessem as pessoas que estão chegando. Se olharmos muito pra isso, a gente desanima. Mas acho que acabamos imprimindo nossa característica na profissão, não podemos ficar olhando para o outro.

Acredito que a enfermagem é uma área que tende a crescer porque o que mais existe nesse mundo é gente doente. Isso nunca vai ter fim. Conforme vem a tecnologia, parece que as doenças vão se multiplicando. Agora tem gente morrendo por causa do mosquito da dengue, olha isso! Um mosquito pequeno! A tendência é aumentar o campo hospitalar, posto de saúde e a assistência. 


\section{Participante 15}

Ser enfermeiro tem que gostar do que faz. Ter mais amor pelo que faz, pelas pessoas, não fazer por obrigação, só pelo dinheiro. O enfermeiro é uma das partes mais importantes na área da saúde, ele é a peça-chave do quebra cabeça, ele tem grande responsabilidade. O médico tá ali, mas são os enfermeiros que fazem boa parte, eles que resolvem. Acho o enfermeiro é a parte principal.

Meu pai sofreu sofrido um acidente e ficou 6 anos paraplégico, acamado, com várias úlceras por pressão pelo corpo. Ele tava entre a vida e a morte e a gente conseguiu ajudá-lo. Não tinha auxiliar, técnico, nem cuidador, nem tinha dinheiro na época. Conseguimos curá-lo porque procuramos orientações dos enfermeiros do posto de saúde. Eles explicavam e a gente fazia em casa. A gente conseguiu absorver aquelas orientações e curamos ele. Curamos, não, não temos o poder da cura, mas conseguimos ajuda-lo a se recuperar. As úlceras foram curadas, ele voltou a andar. Melhorou 100\%. Pensei: "Acho que vou fazer enfermagem". Não fiz auxiliar/técnico de enfermagem entrei direto na faculdade.

No momento da escolha, diante da situação financeira todos da minha família me deram apoio. Outros falaram que eu não ia conseguir. Sou mãe solteira. Sou separada há 3 anos, tenho 3 filhos. Pago aluguel, é difícil, mas minha família me ajuda. Sou cabelereira, e não tem nada a ver com a enfermagem e todo mundo falava que não tinha nada a ver, os amigos, os parentes. Hoje minha mãe ainda fala um pouco. Ela não foi contra, mas ela fala: "Você tem certeza que é isso que você quer?". Acredito que quem tá fora vê o enfermeiro como um profissional que enfrenta grandes dificuldades ao trabalhar com o doente. Você tem que ter pulso firme para trabalhar dentro do hospital. Eles não sabem o que o enfermeiro passa.

No futuro espero me dar muito bem. Tenho um pouco de medo, porque sou muito tímida, mas pretendo ir até o final e conseguir. Quero fazer todos os cursos que preciso, pra não ficar naquela mesmice. Espero que a área da saúde no geral melhore. Tanta gente se formando como enfermeiro que dá até medo. Vai saber se daqui a 10 anos terá espaço para todas as pessoas que estão se formando agora? Desse modo, cai a qualidade na assistência. 


\section{ANEXO}




\section{ANEXO - APROVAÇÃO DO COMITÊ DE ÉTICA E PESQUISA DA EEUSP}

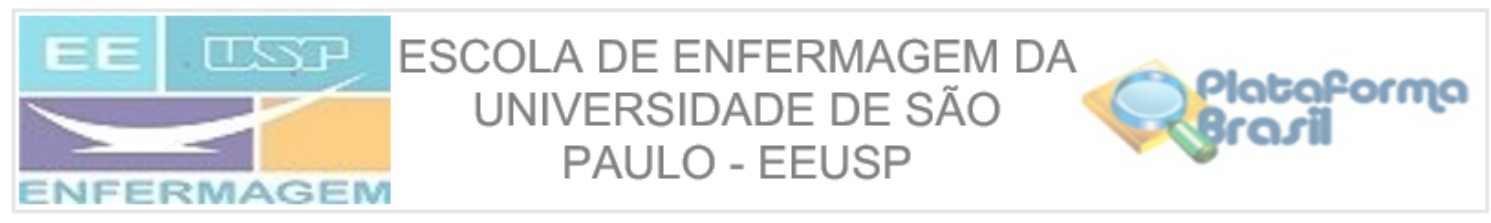

\section{PARECER CONSUBSTANCIADO DO CEP}

\section{DADOS DO PROJETO DE PESQUISA}

Título da Pesquisa: SIGNIFICADOS E PERCEPÇÕES DE GRADUANDOS DE ENFERMAGEM DA UNIESP SOBRE O SER ENFERMEIRO (2010-2014)

Pesquisador: Thaís Araújo da Silva

Área Temática:

Versão: 2

CAAE: 31704214.5 .0000 .5392

Instituição Proponente: Escola de Enfermagem da USP

Patrocinador Principal: Financiamento Próprio

\section{DADOS DO PARECER}

Número do Parecer: 772.015

Data da Relatoria: $26 / 08 / 2014$

\section{Apresentação do Projeto:}

O presente estudo pretende conhecer e compreender as percepções e significados para analisar as articulações da construção da identidade profissional do enfermeiro sob a perspectiva dos graduandos de enfermagem da faculdade UNIESP, no período de 2009 a 2013.

O objeto de pesquisa refere-se à compreensão dos processos de construção da identidade profissional do Enfermeiro a partir da visão que os graduandos desta instituição têm sobre o Enfermeiro. O problema de pesquisa versa sobre "Como se constrói as percepções e significados atribuídos ao ser enfermeiro sob a perspectiva dos graduandos de enfermagem da Faculdade UNIESP e de que maneira essa perspectiva contribui para a construção de uma identidade profissional?

JUSTIFICATIVA DO ESTUDO: O Grupo de Pesquisa em História e Legislação da Enfermagem, do qual participo, tem como foco contribuir para o conhecimento da memória e da antropologia dos cuidados, história de vida e história das instituições, enriquecendo o contexto social e cultural contemporâneo. Cabe destacar que a pesquisadora ao iniciar sua carreira como docente de enfermagem, pôde perceber a necessidade de compreender as percepç̃es dos graduandos dessa área em relação ao "ser" enfermeiro.

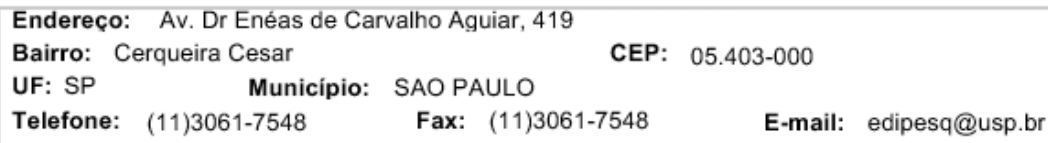




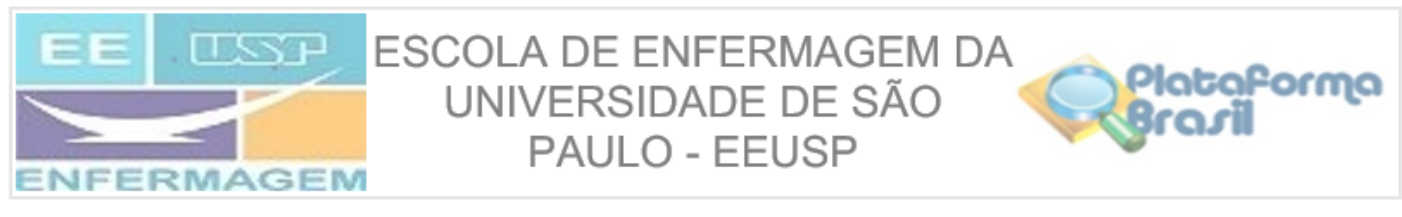

Continuação do Parecer: 772.015

\section{PERCURSO METODOLÓGICO}

Trata-se de um estudo histórico-social, de natureza qualitativa e exploratória, pautada no método da História Oral Temática. O presente estudo será realizado na faculdade UNIESP - Centro Novo, em São Paulo. No período de 2010 a 2014. Serão entrevistados os graduandos do primeiro, quinto e nono semestres da graduação de Enfermagem, aonde serão selecionados cinco participantes, escolhidos aleatoriamente, de cada desses semestres, sendo entrevistados homens e mulheres. Esta escolha será realizada através da busca ativa, diretamente nas salas de aula, onde será aplicado o questionário sócio demográfico. Serão incluídos no estudo aqueles participantes que concordarem em responder ao questionário e a realizar a entrevista. Além disso, como critérios de inclusão foram definidos que os participantes residam no município de São Paulo, ou na região metropolitana; $30 \%$ dos colaboradores do estudo deverão ser profissionais de enfermagem que atuam na área como auxiliares ou técnicos de enfermagem. A coleta de dados será realizada a partir de entrevistas semiestruturadas, compondo-se de um questionário semi-estruturado, de forma individual, em horário previamente agendado e será realizada na própria instituição. As entrevistas serão gravadas em fita cassete e serão transcritas e serão pautadas em quatro questões norteadoras, aplicadas aos graduandos, que permitirão aos sujeitos discorrerem sobre 0 assunto, enriquecendo assim, o conteúdo da entrevista. Em seguida, será aplicado um termo de consentimento livre e esclarecido (TCLE). Para manter o sigilo, os entrevistados serão identificados através de uma sequência numérica arábica. Como fontes primárias serão utilizados os depoimentos dos entrevistados, utilizando-se a História Oral Temática. Como fontes secundárias serão utilizadas teses, dissertações, artigos, localizáveis nas bases de dados eletrônicas, bem como documentos das entidades associativas (Associação Brasileira de Enfermagem, Conselhos Regionais e Conselho Federal de Enfermagem e outras), legislações do exercício e da educação em enfermagem.REFERENCIAL TEÓRICO: A fim de adentrar no tema que ocupa esta pesquisa, será escolhida a abordagem de Claude Dubar. Dubar é professor de Sociologia na Universidade de Versailles-Saint. Consagrou a sua tese e numerosas publicações à formação contínua e à inserção dos jovens. Este autor relata que não há uma diferença entre identidade social e identidade profissional, pois o trabalho está no centro do processo de construção/desconstrução/reconstrução das formas identitárias profissionais. Ele foca na interação do indivíduo com o sistema ao qual ele es tá inserido, sua relação com o futuro, e no modo como ele descreve

e vivencia uma situação.

\section{Objetivo da Pesquisa:}

- Mapear o perfil dos graduandos de enfermagem da Faculdade UNIESP: procedência, religião,

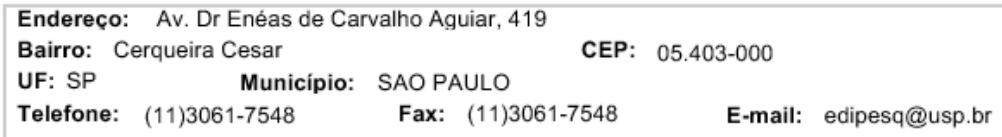




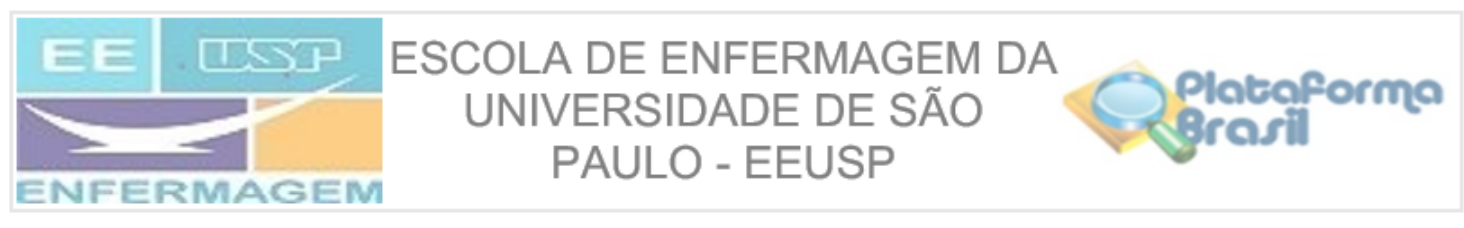

Continuação do Parecer: 772.015

estado civil, idade, naturalidade, sexo, etnia, se cursou o ensino fundamental e médio em escola pública ou privada trabalha, se trabalha na área de enfermagem como auxiliar de enfermagem ou técnico de enfermagem, residência habitual, se possui algum tipo de bolsa estudantil, escolha profissional;

- Identificar as expectativas dos colaboradores em relação à escolha profissional, experiências e percepções dos colaboradores sobre o ser enfermeiro;

- Analisar e discutir os significados e percepções atribuídas pelos colaboradores na construção identitária do que é ser enfermeiro, na perspectiva do referencial teórico de Claude Dubar.

\section{Avaliação dos Riscos e Benefícios:}

Não há riscos físicos, pois os estudantes serão convidados a falar sobre sua carreira.

Benefícios: Aprofundamento da temática estudada, preenchendo lacunas a partir dos discursos e vivências dos colaboradores quanto à construção identitária do enfermeiro.

\section{Comentários e Considerações sobre a Pesquisa:}

A pesquisa contempla todos os passos necessários para sua execução.

A linguagem utilizada é clara e adequada para um estudo científico.

O tema é relevante para a área de Enfermagem, visto que os resultados possibilitarão aprofundamento da temática estudada, preenchendo lacunas a partir dos discursos e vivências dos colaboradores quanto à construção identitária do enfermeiro.

\section{Considerações sobre os Termos de apresentação obrigatória:}

Os termos de apresentação obrigatória estão relatados de forma correta, incluindo a aprovação da Instituição CO-participante com a carta de anuência.

\section{Recomendações:}

Não há.

Conclusões ou Pendências e Lista de Inadequações:

- COLOCADA A DURAÇÃO APROXIMADA DAS ENTREVISTAS NO TCLE.

- Colocada a RESOLUÇÃO 466/12 nos aspectos éticos do projeto;

\section{Situação do Parecer:}

\section{Aprovado}

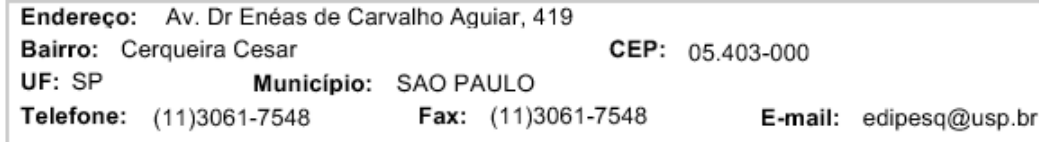




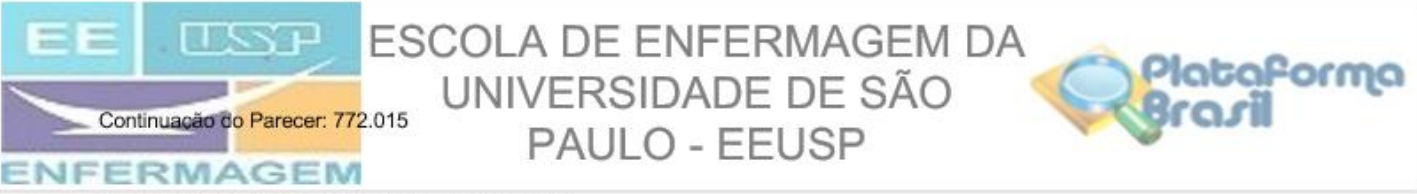

Necessita Apreciação da CONEP:

Não

Considerações Finais a critério do CEP:

A aprovação do Comitê de Ética em Pesquisa da EEUSP não substitui a autorização da instituição co- participante para o início da pesquisa.

O CEP EEUSP informa que há necessidade de registro dos relatórios: parcial e final da pesquisa, na

Plataforma Brasil.

SAO PAULO, 29 de Agosto de 2014

Assinado por:

Ruth Natalia Teresa Turrini

(Coordenador)

Endereço: Av. Dr Enéas de Carvalho Aguiar, 419

Bairro: Cerqueira Cesar

CEP: $\quad 05.403-000$

UF: SP

Municipio: SAO PAULO

Telefone: (11)3061-7548

Fax: (11)3061-7548

E-mail: edipesq@usp.br 